\title{
3D Seismic Interpretation, Mechanical Stratigraphy and Production Analysis of the Marcellus Shale in Northern West Virginia
}

Mollie K. Kish

Follow this and additional works at: https://researchrepository.wvu.edu/etd

\section{Recommended Citation}

Kish, Mollie K., "3D Seismic Interpretation, Mechanical Stratigraphy and Production Analysis of the Marcellus Shale in Northern West Virginia" (2016). Graduate Theses, Dissertations, and Problem Reports. 5987.

https://researchrepository.wvu.edu/etd/5987

This Thesis is protected by copyright and/or related rights. It has been brought to you by the The Research Repository @WVU with permission from the rights-holder(s). You are free to use this Thesis in any way that is permitted by the copyright and related rights legislation that applies to your use. For other uses you must obtain permission from the rights-holder(s) directly, unless additional rights are indicated by a Creative Commons license in the record and/ or on the work itself. This Thesis has been accepted for inclusion in WVU Graduate Theses, Dissertations, and Problem Reports collection by an authorized administrator of The Research Repository @ WVU. For more information, please contact researchrepository@mail.wvu.edu. 
3D Seismic Interpretation, Mechanical Stratigraphy and Production Analysis of the Marcellus Shale in Northern West Virginia

Mollie K. Kish

Thesis submitted to the

Eberly College of Arts and Sciences at West Virginia University

in partial fulfillment of the requirements for the degree of

Master of Science in

Geology

Thomas H. Wilson, Ph.D., Chair

Timothy R. Carr, Ph.D.

Dengliang Gao, Ph.D.

David Boyer

Department of Geology and Geography

Morgantown, West Virginia

2016

Keywords: Marcellus Shale, Rome Trough, 3D Seismic

Copyright 2016 Mollie Kish 


\section{ABSTRACT \\ 3D Seismic Interpretation, Mechanical Stratigraphy and Production Analysis of the Marcellus Shale in Northern West Virginia}

\section{Mollie K. Kish}

The Marcellus shale is one of the most developed unconventional shale gas reservoirs in the world with a calculated 84.5 trillion cubic feet in proved natural gas reserves in Pennsylvania and West Virginia. To better exploit this resource all geological aspects of the Marcellus shale are being studied. In this study, mechanical stratigraphy and interpreted seismic fracture zones within the Marcellus shale are examined. These geologic criteria are assessed for potential to impact gas production by analyzing the gas production of fourteen horizontal Marcellus shale wells within and around the study area.

Mechanical stratigraphy is evaluated from the top of the Tully limestone to the base of the Onondaga limestone to assess vertical heterogeneity of brittleness within and around the Marcellus shale. Brittleness estimations are derived from petrophysical well logs including bulk density, shear velocity and compressional velocity. Mineralogy assessment is completed using Schlumberger’s SpectroLith ${ }^{\circledR}$ gamma ray spectroscopy mineralogy logs. Elastic moduli including Young's modulus, Poisson's ratio and Lame's parameters are assessed in terms of brittleness and total organic content to develop constraints for areas of high brittleness and high total organic content. The constraints developed at the study well are compared to studies at four other unconventional shale gas sites. The results suggest that mechanical properties are variable and site dependent. Conclusive ranges for Poisson's ratio and Young's modulus constraints for areas of high brittleness and high total organic cannot be developed for an entire shale play but may be useful in local analyses.

Seismic discontinuities were extracted from two three dimensional seismic surveys using a post-stack processing workflow that included Ant-Tracking. They are interpreted to be associated with small faults and fracture zones. The relationship between the number of seismic discontinuities intersecting horizontal wells in the Marcellus shale and cumulative gas production was evaluated. Number of intersecting discontinuities per 1000 feet of wellbore is linearly correlated to cumulative gas production with $\mathrm{R}^{2}$ values greater than 0.9 . 


\section{ACKNOWLEDGEMENT}

I would first like to extend my gratitude to my thesis committee members Dr. Timothy Carr and Dr. Dengliang Gao from the department of Geology and Geography here at West Virginia University. Thank you for all of your time, suggestions and help the past two years. I am also grateful for the classes you teach that have taught me the basics of well log analysis and 3D seismic interpretation needed to complete this research.

I would next like to thank the third member of my committee Dave Boyer of Mountaineer Keystone LLC. Thank you for being a part of my thesis effort, providing helpful questions and positive feedback. I am extremely grateful to Mountaineer Keystone LLC. for donating the 3D seismic and well $\log$ dataset to make this research possible. I would also like to thank Daniel Amrine of PDC Mountaineer for helping me get this project started.

I am grateful for the guidance of three $\mathrm{PhD}$ candidates here at the Geography and Geology Department at West Virginia University: Shuvajit Bhattacharya, Payam Kavousi and Valerie Smith. Each of you has helped me in some way with my research the past two years. I see each of you work tirelessly on your own dissertations, but still find time to help me. I am grateful for your time and motivated by your diligence and love for this field.

This research would not have been possible without the software donations from Schlumberger, SMT and IHS. I would also like to thank the West Virginia Geologic and Economic Survey for posting oil and gas production data online for public consumption.

I am grateful for the West Virginia University Department of Geology and Geography for providing me a teaching assistantship for four semesters to make this research possible.

Most importantly, I would like to extend my greatest appreciation to my thesis chairman Dr. Thomas Wilson. Thank you for accepting me as a graduate student and your willingness to be my advisor. Your subsurface interpretation class helped me find a research direction my first semester at West Virginia University that is now transforming into a career I am passionate about. I am grateful for the opportunity to have worked with you as a professor and my thesis chairman. 


\section{TABLE OF CONTENTS}

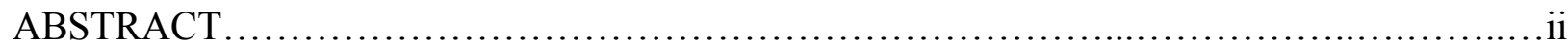

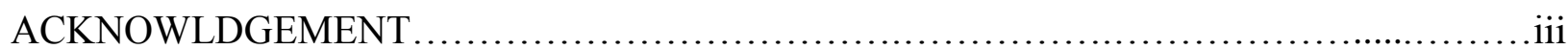

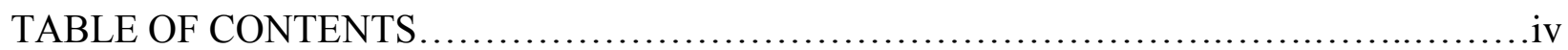

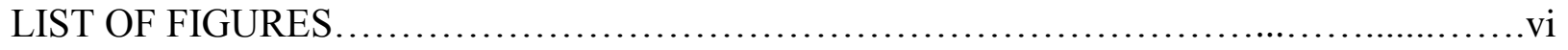

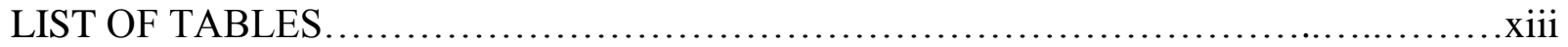

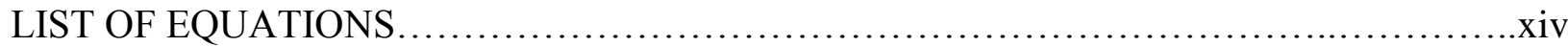

\section{CHAPTERS}

I. INTRODUCTION

1.1 Goals

1.2 Previous Work

1.2.1 Previous Marcellus Shale 3D Seismic Analysis

1.2.2 Previous Marcellus Shale Lithological Analysis

1.3 Dataset

1.2.3 Previous Marcellus Shale Production Analysis

II. GEOLOGIC SETTING...

2.1 Appalachian Basin

2.2 Structural Setting

2.1.1 Orogenic Events

2.1.2 General Stratigraphy

2.3 Marcellus Shale

2.2.1 Contemporary Stress Field

2.3.1 Depositional Environment

III. LITHOLOGIC ANALYSIS...........................................18

3.1 Marcellus Shale Overview

3.1.1 Marcellus Shale Characteristics and Type Log

3.2 Goff \#55 Well Log Interpretation

3.2.1 Mineralogy

3.2.2 Mechanical Stratigraphy

IV. SEISMIC WELL TIE AND RESOLUTION.............................43

4.1 Synthetic Seismogram

4.2 Horizon Picking

4.3 Vertical Resolution

4.4 Acoustic Logs Response and Seismic Character

V. SEISMIC INTERPRETATION

5.1 Seismic Structure Maps

5.2 Dip Angle Maps

5.3 Fault Interpretation

5.4 Isochore Maps

5.5 Natural Fracture Analysis 
5.5.1 Three Dimensional Seismic Discontinuities

VI. HYDROCARBON IMPLICATIONS...................................106

6.1 An Introduction to Hydrocarbon Production in the Appalachian Basin

6.2 Marcellus Shale Hydrocarbon Production

6.2.1 Analysis of Existing Marcellus Shale Wells

6.2.2 Recommendations for Future Marcellus Shale

Development

VII. SUMMARY AND CONCLUSIONS....................................125

VIII. FUTURE WORK........................................................126

REFERENCES CITED ........................................................... 127 


\section{LIST OF FIGURES}

Figure 1: Location map for the seismic datasets in Harrison County West Virginia. Figure A shows the location of West Virginia in the United States. Figure B shows the locations of Harrison County in West Virginia. Figure C shows the outline of Harrison County, the approximate location of the Wolf Summit anticline, the Goff 3D seismic survey, the Gepco 3D seismic survey and fourteen horizontal wells............................................. 6

Figure 2: Sedimentary basins of the lower 48 states in the United States shaded in green. Gas plays are shaded in orange. Oil and higher chain hydrocarbon plays are shaded in blue. This image depicts the Appalachian basin containing the largest gas play in the United States (Pac West Consulting Partners, 2014)...............................................

Figure 3: Geologic map of West Virginia (West Virginia Geologic and Economic Survey, 2011). Harrison County is in the north central portion on the state and contains rocks of Pennsylvanian and Permian age...................................................... 8

Figure 4: Depiction of past orogonies that formed the Appalachian Mountains and subsequent Appalachian basin (Fichter, 1993). During the Middle Devonian the Marcellus shale was deposited as an organic rich mud in the Catskill foreland basin circled here in green.............10

Figure 5: The Catskill delta W-E stratigraphic section in the Appalachian basin (Ettenshon, 2004). The Marcellus shale was deposited during the Middle Devonian. Figure is not to scale............................................................................ 11

Figure 6: Simple stratigraphic column of the Marcellus shale and bounding strata (Wrightstone 2009). Brown indicates shale, black indicates black shale, blue is limestone and yellow is sandstone. Red indicates New York terminology.....................................12

Figure 7: The structural geology of the Appalachian basin adapted from Ryder et al. 2009 Geological Survey publication. Harrison County lies over the Rome trough. The Wolf Summit anticline (WSA) directly bisects the county Northeast-Southwest. Blue square denotes approximate location of Goff 3D and Gepco 3D surveys between WSA and the Chestnut Ridge

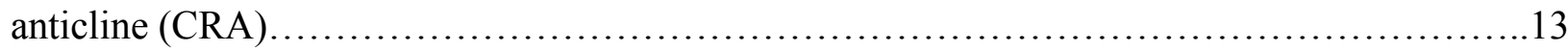

Figure 8: Map showing contemporary stress orientations in the Appalachian basin (Heidbach et al., 2008). The symbol denotes the measurement method for the data point, the color of the symbol denotes which stress regime the data point is in and the length of the line denotes the quality of the data point. Only A, B and C quality data points are used (Zoback and Zoback,

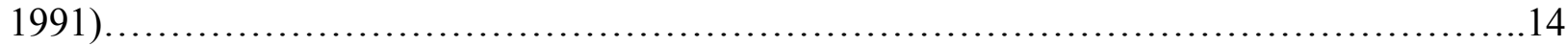

Figure 9: The depth to the Marcellus shale base with 1000 foot contour interval and Marcellus shale extent in green (Marcellus Center for Outreach and Research, 2008). In Harrison County the Marcellus shale is 7000-8000 feet deep. Approximate location of study well marked by red circle 
Figure 10: The thickness of the Marcellus shale with 50 foot contour interval (Marcellus Center for Outreach and Research, 2008). In Harrison County the Marcellus shale is between the 50 foot and 150 foot contour intervals. Approximate location of study well marked by red circle........16

Figure 11: Paleogeographic map of the United States during the Devonian (modified from Blakey, 2008). The future United States is outlined. During the Devonian the United States are located below the paleo equator (marked in this image by a white line). The study area is marked by a small red circle in the shallow epicontinental sea.................................... 17

Figure 12: Type log for the Upper to Middle Devonian strata in the study. Geophysical characteristics of the Marcellus shale are a gamma ray response of over 200 API, a photoelectric index value less than five Barnes/electron, a bulk density less than $2.55 \mathrm{~g} / \mathrm{cc}$ and a total organic content of greater than three percent.................................................... 19

Figure 13: Goff \#55 well with gamma ray, total organic content, brittleness index, compositional logs, bulk density and velocity to show characteristic changes in these log responses from the

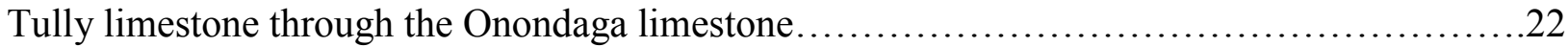

Figure 14: Goff \#55 well with gamma ray, total organic content, brittleness index, compositional logs, bulk density and velocity to show zoomed in view of characteristic changes in these $\log$ responses within and around the Marcellus shale..........................................23

Figure 15: Schlumberger (2016) ternary diagram to classify rocks based on three major mineralogical compositions 24

Figure 16: Four stratigraphic units in the study well plotted to assess mineralogy and rock

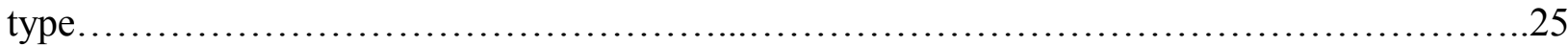

Figure 17: Four stratigraphic units in the study well shaded with total organic content.........26

Figure 18: Marcellus shale shaded with total organic content............................26

Figure 19: RHOmaa Umaa cross plot with depth interval for the entire well................28

Figure 20: Depth interval from -7163 to -7235 feet measured depth to highlight the organic rich Marcellus shale plotting in the gas detection region....................................... 28

Figure 21: Brittleness Index and gamma ray cross plot color coded by formation. Ductile and brittle constraints by Perez and Marfurt (2013)...................................... 32

Figure 22: Brittleness Index and gamma ray cross plot shaded by TOC. Ductile and brittle constraints with TOC by Perez and Marfurt (2013)......................................33

Figure 23: Cross section of TOC, brittleness index, mineralogy and mechanical logs for the Marcellus shale interval........................................................ 36

Figure 24: Lambda-rho and Mu-rho cross plot from the study well in Harrison County color coded by formation. .37

Figure 25: Lambda-rho and Mu-rho cross plot from the study well in Harrison County color coded by total organic content. .38 
Figure 26: Lambda-rho and Mu-rho cross plot from the study well in Harrison County color

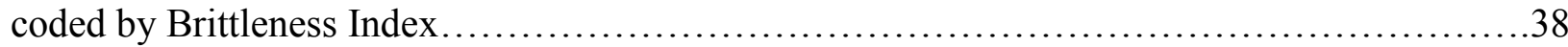

Figure 27: Lambda-rho and Mu-rho cross plot with Poisson's ratio and Young's modulus cut off

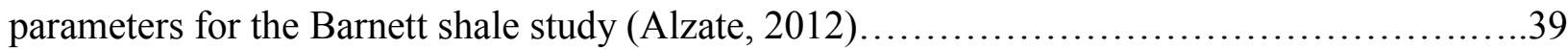

Figure 28: Lambda-rho and Mu-rho cross plot with Poisson's ratio and Young's modulus cut off parameters for the Harrison County Marcellus shale study..................................40

Figure 29: Lambda-rho and Mu-rho cross plot with Poisson's ratio and Young's modulus cut off parameters for the Monongalia County Marcellus shale (Wilson, 2015 unpublished class lecture).

Figure 30: A: Goff 3D seismic extracted wavelet used for synthetic seismogram creation. B: Tuning thickness chart for this extracted wavelet, the peak of the tuning curve rests at 0.011 seconds marked by a purple line .................................................... 44

Figure 31: Logs and wavelet used in the creation of the synthetic seismogram at the Goff 55 well with neighboring seismic traces. The Tully and Onondaga limestone reflection events are labeled to highlight the Middle Devonian stratigraphy and overlying Sycamore sandstone for stratigraphic reference.

Figure 32: Zoomed in view of the synthetic seismogram with labeled Middle Devonian stratigraphy. .46

Figure 33: Kulander and Ryder (2005) figure to show location of Burley No.1 well that has a synthetic seismogram to the basement and the location of the $2 \mathrm{D}$ seismic line that is near the 3D seismic surveys in this study. . .48

Figure 34: Kulander and Ryder (2005) regional 2D seismic line A-A' over the Wolf Summit Anticline. Left image is interpreted and middle image is uninterpretted. The right image shows the Goff 3D seismic crossline 77 with interpreted reflections.

Figure 35: Velocity curve for the Middle Devonian stratigraphy at the Goff \#55 well. The Marcellus shale has an average velocity of $11,693 \mathrm{ft} / \mathrm{sec}$ and is subdivided into upper, middle and

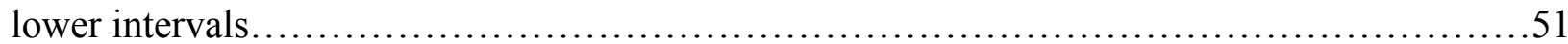

Figure 36: Goff \#55 well with gamma ray, total organic content, brittleness index, compositional logs, bulk density and velocity for correlating properties between sonic and density logs with mineralogy and Brittleness Index. .54

Figure 37: Synthetic seismogram displayed on the Goff 55 well path at an arbitrary line in the Goff 3D seismic survey. A seismic wiggle trace is highlighted to compare to the generated synthetic. The gamma ray, sonic and density logs are also displayed for correlation with seismic character. The location of this seismic profile is outlined in blue on the seismic reference map. .55

Figure 38: Middle Devonian zoomed in view of the synthetic seismogram displayed on the Goff 55 well path at an arbitrary line in the Goff 3D seismic survey. A seismic wiggle trace is 
highlighted to compare to the generated synthetic. The gamma ray, sonic and density logs are also displayed for correlation with seismic character. The location of this seismic profile is outlined in blue on the seismic reference map..........................................56

Figure 39: Goff 55 well path and seismic wiggle trace is highlighted on an arbitrary seismic line of a spectral whitening volume of the Goff 3D. The gamma ray, sonic and density logs are also displayed for correlation with this seismic character. The location of this seismic profile is outlined in blue on the seismic reference map.......................................... 57

Figure 40: Marcellus shale seismic horizon which represents the geologic subsurface map of the structure of the top of the Marcellus shale. Relatively deep is indicated by purple while relatively shallow is indicated by red. The Wolf Summit Anticline (WSA) and Shinnston Syncline (SS) are labeled. This map is the top of the Marcellus shale and the location of horizontal wells are shown for reference only

Figure 41: Onondaga limestone seismic horizon which represents the geologic subsurface map of the structure of the base of the Marcellus shale. Relatively deep is indicated by purple while relatively shallow is indicated by red. The Wolf Summit Anticline (WSA) and Shinnston Syncline (SS) are labeled. This map is the top of the Onondaga limestone and the location of horizontal wells are shown for reference only.

Figure 42: Trenton limestone seismic horizon which represents the geologic subsurface map of the structure of the top of the Trenton limestone. Relatively deep is indicated by purple while relatively shallow is indicated by red. Deep areas at the edge of both surveys show a synclinal feature between the two.

Figure 43: Black River limestone seismic horizon which represents the geologic subsurface map of the structure of the base of the Trenton limestone. Relatively deep is indicated by purple while relatively shallow is indicated by red. Deep areas at the edge of both surveys show a synclinal feature between the two.

Figure 44: Marcellus shale seismic horizon in dip angle which represents the amount in degrees of dip of the subsurface horizon of the top of the Marcellus shale. Blue and purple indicate a nearly flat horizon with a dip of less than four degrees. The location of horizontal wells are shown for reference

Figure 45: Onondaga limestone seismic horizon with dip angle attribute which represents the amount in degrees of dip of the subsurface horizon of the top of the Onondaga limestone. Blue and purple indicate a nearly flat horizon with a dip of less than four degrees. The location of

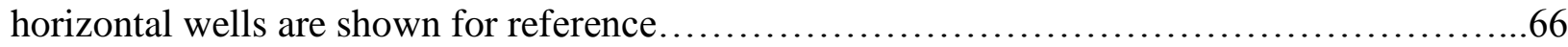

Figure 46: Trenton limestone seismic horizon in dip angle which represents the amount in degrees of dip of the subsurface horizon of the top of the Trenton limestone. Blue and purple indicate a nearly flat horizon with a dip of less than one degree.

Figure 47: Black River limestone seismic horizon in dip angle which represents the amount in degrees of dip of the subsurface horizon of the base of the Trenton limestone. Blue and purple indicate a nearly flat horizon with a dip of less than one degree. .68 
Figure 48: Petrel 3D Window view of the workflow process for interpreting faults with 20x vertical exaggeration as viewed from the southeast. Seismic amplitude, TVTAS and variance volumes are all used to assess the location of a fault below the Trenton limestone reflection event in the Goff 3D......................................................................

Figure 49: Petrel Interpretation Window of the Goff 3D seismic dataset at an arbitrary line A-A' perpendicular to the northeast trending structure observed in structure maps. Extensional faults are colored blue and compressional faults are colored yellow............................ 72

Figure 50: Petrel 3D Window showing the Goff 3D and interpreted faults form the Elk Group to the Grenvillian basement. The three horizons shown from shallow to deep are the Marcellus shale, Trenton limestone and interpreted basement. This figure depicts the complicated multilevel fault stacking between the Trenton limestone and the basement.........................73

Figure 51: Marcellus shale thickness map. Marcellus shale wells within the 3D seismic are

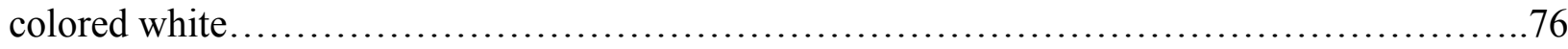

Figure 52: Trenton limestone thickness map.................................... 77

Figure 53: Modified from Kulander and Ryder (2005). Yellow rectangle indicates the seven seismic stratigraphic packages analyzed in this section. .79

Figure 54: Thickness map from the top of the Black River limestone to the top of the Copper Ridge dolomite to depict the thickness of the Beekmantown Group seismic stratigraphic package. .83

Figure 55: Thickness map from the top of the Trenton limestone to the top of the Black River limestone to depict the thickness of the Trenton limestone seismic stratigraphic package........84

Figure 56: Thickness map from the top of the Reedsville shale to the top of the Trenton limestone to depict the thickness of the Reedsville shale seismic stratigraphic package.........85

Figure 57: Thickness map from the top of the Tuscarora sandstone to the top of the Reedsville shale to depict the thickness of the Juanita Group seismic stratigraphic package................86

Figure 58: Thickness map from the top of the Salina Group to the top of the Tuscarora sandstone to depict the thickness of the Salina Group seismic stratigraphic package............87

Figure 59: Thickness map from the top of the Tully limestone to the top of the Salina Group to depict the thickness of the Hamilton Group seismic stratigraphic package. .88

Figure 60: Thickness map from the top of the Java Formation to the top of the Tully limestone to depict the thickness of the Elk Group seismic stratigraphic package.......................89

Figure 61: Thickness maps of the Goff 3D seismic stratigraphic packages in successive order to compare thickness changes throughout time.... .90

Figure 62: A: Arbitrary seismic line perpendicular to the fault. B: Seismic line drawing of the thickness changes of major seismic stratigraphic packages. C: Location of the seismic line in the Goff 3D seismic survey with an outline of Harrison county West Virginia. 
Figure 63: Thickness change over the northwest fault block reported as a percent change relative to thickness over the southeast fault block. 92

Figure 64: Plotted orientations of interpreted joints in the Huron shale. The Huron is one of the black shales in the Middle and Upper Devonian section of the Appalachian basin that carries regional joint sets and may provide insight into the fracturing trends of the Marcellus shale. These orientations are observed from cores (Engelder et al., 2009)........................94

Figure 65: Top: Goff 3D Marcellus shale surface map with extracted Ant Tracking attribute, not interpreted. Bottom: The same Marcellus shale horizon with interpreted seismic discontinuities..................................................................... 96

Figure 66: Top: Goff 3D Onondaga limestone surface map with extracted Ant Tracking attribute, not interpreted. Bottom: The same Onondaga limestone horizon with interpreted seismic discontinuities.

Figure 67: Top: Gepco 3D Marcellus shale surface map with extracted Ant Tracking attribute, not interpreted. Bottom: The same Marcellus shale horizon with interpreted seismic discontinuities .98

Figure 68: Top: Gepco 3D Onondaga limestone surface map with extracted Ant Tracking attribute, not interpreted. Bottom: The same Onondaga limestone horizon with interpreted seismic discontinuities.

Figure 69: Rose diagrams of Marcellus and Onondaga surfaces seismic discontinuities frequency and orientation for the Goff 3D and the Gepco 3D.

Figure 70: A: Location of four three dimensional seismic surveys where Marcellus shale seismic discontinuity analyses were completed. B: Major Marcellus shale discontinuity trends plotted with contemporary stress orientations. Maps modified from the World Stress Map Project (Zoback et al., 2008)....

Figure 71: Graph from the United States Energy Information Administration (2014) depicting gas production in Pennsylvania (Appalachian basin) is quickly on the rise due to the hydraulic fracturing of the Marcellus shale. ... 107

Figure 72: Graph from the United States Energy Information Administration (2014) depicting gas production in the United States showing that in 2013 shale gas production surpassed every other kind of production.

Figure 73: Graph showing the first 12 months of production of all the Marcellus shale wells in the study area from least production to greatest production.

Figure 74: Graph showing the same 12 month production but on a per foot basis based on lateral length. Note the changes in which wells are viewed as best producer... 110

Figure 75: Graph showing all of the production since first month of production for all the wells in the study area.

Figure 76: Graph showing all of the production since first month of production for all the wells in the study area on a per foot basis. 
Figure 77: Interpreted seismic discontinuities near the Marcellus shale for the Goff 3D and Gepco 3D with the horizontal Marcellus shale wells plotted...............................114

Figure 78: Cross plot of first year cumulative production data and frequency of interpreted seismic discontinuities that intersect the horizontal well.................................115

Figure 79: Cross plot of two year cumulative production data and frequency of interpreted seismic discontinuities that intersect the horizontal well.................................116

Figure 80: Cross plot of third year cumulative production data and frequency of interpreted seismic discontinuities that intersect the horizontal well ...................................116

Figure 81: Cross plot of first year cumulative production and frequency of seismic discontinuities that intersect the horizontal well normalized by length.

Figure 82: Cross plot of second year cumulative production and frequency of seismic discontinuities that intersect the horizontal well normalized by length.

Figure 83: Cross plot of third year cumulative production and frequency of seismic discontinuities that intersect the horizontal well normalized by length.

Figure 84: Type curve example showing how Range Resources (2015) does their decline curve for unconventional shale gas production estimates to obtain EUR.

Figure 85: A: Petra's Production Group Normalization Plot showing the monthly gas production for the Goff 5HM well. B: Petra's Decline Curve Analysis showing the manual hyperbolic fit line to estimate EUR over a 20 year production history for the same well.

Figure 86: Estimated ultimate recovery contour map based on lateral length. Each well's EUR data is posted at the toe of each lateral. The higher expected EUR wells are located in proximity to the trend of the axis of the Wolf Summit Anticline. Approximate locations of the Goff 3D and Gepco 3D seismic surveys are labeled.

Figure 87: Comparison of gas production at multiple well sites with varying Marcellus shale thicknesses 


\section{LIST OF TABLES}

Table 1: Geophysical log reference values of gamma ray, photoelectric index, bulk density and TOC of the Marcellus shale and bounding strata (Repetski at al., 2005; Milici and Swezey, 2006; Boyce, 2010)....................................................................... 18

Table 2: Poisson's ratio and Young's modulus ranges for the multiple lambda-rho mu-rho studies (Alzate 2012, Weicht 2015, Wilson 2015 unpublished).

Table 3: Average interval velocity, tuning time, dominant period, resolvable thickness and stratigraphic thickness for the Middle Devonian stratigraphy in the Goff \#55 well. The Marcellus shale is resolvable in the Goff 3D seismic dataset.

Table 4: Average velocity used to convert two-way time seismic structure maps into the depth domain.

Table 5: Average velocity used to convert two-way time seismic structure maps into the depth domain in order to create thickness maps in feet.

Table 6: Summary of sources for contemporary stress orientations in the Appalachian basin near the study area in Harrison County West Virginia. Table summarizes author, year, location of the data point, method the data was collected and observed orientation of maximum horizontal stress.

Table 7: Summary of case studies using 3D seismic discontinuity analysis with average trends interpreted for the Marcellus shale....

Table 8: Information obtained from the Unconventional Hydrocarbon Resources Atlas showing the top 10 natural gas producing counties in PA, OH and WV as of December 2014. Harrison County is the only county from WV in the top 10. Note: cumulative production is from the start date of the wells within each county and unconventional development may have started earlier in some areas.... 108

Table 9: Summary of the nine wells within the seismic surveys that have horizontal deviation surveys and at least one years of production data....

Table 10: Analysis of two wells with dissimilar frequency of interpreted seismic discontinuity frequency crossing the lateral well.... 


\section{LIST OF EQUATIONS}

Equation 1: RHOmma equation where RHOB is the bulk density and PHIA is the average porosity.

Equation 2: Umma equation where $U$ is the volumetric photoelectric absorption index and PHIA is the average porosity.

Equation 3: Volumetric photoelectric absorption index (U) equation where $\mathrm{Pe}$ is the photoelectric factor and $\rho b$ is the bulk density (Doveton, 1994)..... 27

Equation 4: Brittleness Index (BI) equation proposed by Jarvie (2007) where Qz is percentage of quartz, $\mathrm{Ca}$ is percentage of calcite and Cly is percentage of clay.

Equation 5: Brittleness Index (BI) equation proposed by Wang and Gale (2009) where Qz is percentage of quartz, Dol is percentage of dolomite, $\mathrm{Ca}$ is percentage of calcite and Cly is percentage of clay, and TOC is total organic content.................................. 30

Equation 6: Young's modulus (E) equation where $\sigma$ is the tensile stress and $\varepsilon$ is the extensional strain. 30

Equation 7: Poisson's ratio ( $v$ ) equation where etrans is the transverse strain and caxial is the axial strain. 30

Equation 8: Poisson's ratio (v) equation, where Vs is the shear velocity and Vp is the compressional velocity. .31

Equation 9: Young's modulus (E) equation, where $\rho$ is the rock density $(\mathrm{g} / \mathrm{cc})$, Vs is the shear velocity, and $\mathrm{Vp}$ is the compressional velocity....

Equation 10: Young's modulus brittleness (Ebrittleness) equation, where E is Young's modulus, Emin is the minimum Young's modulus and Emax is the maximum Young's modulus..........31

Equation 11: Poisson's ratio brittleness (vbrittleness) equation, where $v$ is Poisson's ratio, vmin is the minimum Poisson's ratio and vmax is the maximum Poisson's ratio .31

Equation 12: Brittleness average (BA) equation averaging the Young's modulus brittleness and Poisson's ratio brittleness.

Equation 13: Lame's first parameter $(\lambda)$ expressed in terms of density $(\rho)$, compressional wave velocity $(\mathrm{Vp})$ and shear wave velocity $(\mathrm{Vs})$.

Equation 14: Lame's first parameter $(\lambda)$ expressed in terms of Young's modulus (E) and Poisson's ration $(v)$ 33 
Equation 15: Lame's second parameter $(\mu)$ expressed in terms of density $(\rho)$ and shear wave

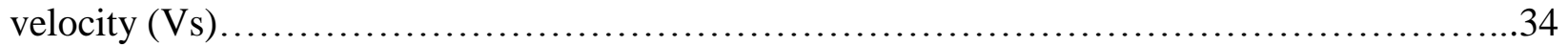

Equation 16: Lame's second parameter $(\mu)$ expressed in terms of Young's modulus (E) and

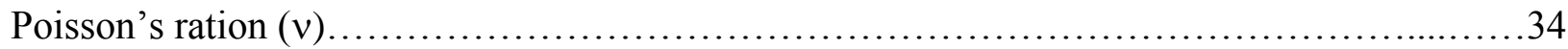

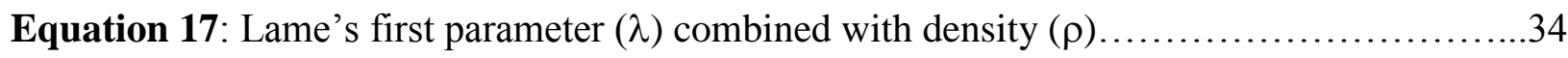

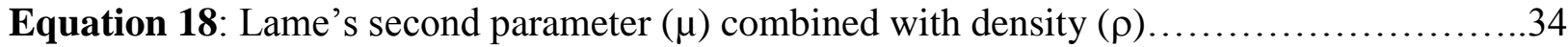

Equation 19: Acoustic impedance where $\rho$ is density and $V$ is velocity....................43

Equation 20: Seismic reflectivity $(\mathrm{R})$ expressed in terms of acoustic impedance...............43

Equation 21: Minimum resolvable thickness (MRT) where $V$ is velocity and $\tau$ is the period...50 


\section{INTRODUCTION}

\subsection{Goals}

The goals of this research include:

1) Perform a lithological analysis of the Marcellus shale and bounding strata using geophysical well logs to evaluate mineralogy, organic content and brittleness, see Chapter 3: Lithological Analysis.

2) Complete a $3 \mathrm{D}$ seismic structural analysis for reflections of interest and develop a chronology of deformation history using isotime maps to assess local structure and possible relationships to a reactivated basement fault. A structural analysis of Ordovician age stratigraphy will help assess potential hazards and targets for deeper unconventional drilling in the study area, see Chapter 5: Seismic Interpretation.

3) Analyze orientations of interpreted fracture zones and small faults observed in 3D seismic extracted discontinuities. Orientation analysis will be integrated into results from previous studies to develop a more comprehensive view of 3D seismic derived discontinuity trends in the surrounding region, see Chapter 5: Seismic Interpretation.

4) Compile one, two, three and four year cumulative production data from fourteen horizontal wells in the study area. Production analysis will be evaluated in the context of 3D seismic interpreted fracture zones, small faults, and deformation history, see Chapter 6: Hydrocarbon Implications.

The results of this study will improve our understanding of the subsurface geology and production from the Marcellus shale within Harrison County West Virginia. The final product will include recommendations for locations of future wells, see Chapter 6: Hydrocarbon 
Implications. The interpretations developed in this study will improve our understanding of factors that influence unconventional gas production in the area and aid in the development of future wells within analogous areas, see Chapter 7: Summary and Conclusions.

\subsection{Previous Work}

The Marcellus shale has been studied extensively through 3D seismic analysis, log analysis and production analysis. Previous 3D seismic studies assess the structure and discontinuity of the Marcellus shale in the Appalachian basin through utilization of seismic attributes (Donahoe, 2001; Babarsky, 2012; Zhu; 2013; Hart, 2014; Wilson et al., 2016). Previous log analysis studies determine brittle and organic rich zones (Boyce, 2010; Weicht 2015; Hilliard, 2015). Previous production studies assess differences in production of unconventional wells (Hart, 2015 and Weicht, 2015).

\subsubsection{Previous Marcellus Shale 3D Seismic Analysis}

Donahoe (2011) used curvature, Ant Tracking and waveform model regression (Gao, 2002, 2004) to interpret an area of the Marcellus shale in southwestern Pennsylvania. Donahoe's study interpreted detachment faults and small scale shear zones oriented from 105 to 120 degrees.

Babarsky (2012) used amplitude, first derivative, curvature, variance and ant tracking to analyze the Marcellus shale in Greene and Washington counties in Pennsylvania. Babarsky's study documented NE/SW trending detachment surfaces and thrust faults along with three separate fault sets oriented at 30, 300 and 330 degrees. Additionally, the application of spectral decomposition in this study enabled Babarsky to detect a sub-seismic scale fracture network that 
could serve as a potential migration pathway for hydrocarbons and communication between laterals.

Zhu (2013) used absolute amplitude, first derivative, second derivative, variance, chaos, dip deviation, 3D curvature, and ant tracking to interpret the discontinuities of the Marcellus shale in Taylor county West Virginia. Zhu observed dominant seismic discontinuity trends of N52E and N45W and suggested the orientations should be considered in decisions of future lateral well orientation.

Wilson et al. (2016) used time-variant trace amplitude slicing, $t^{*}$ attenuation, dip deviation and Ant Tracking in a discontinuity detection workflow to analyze the Marcellus shale of southwestern Pennsylvania. This study extracted seismic discontinuities oriented along N52E and N41W trends and larger ( 250 foot offset) faults with a N25E trend.

\subsubsection{Previous Marcellus Shale Lithological Analysis}

Boyce (2010) developed defining characteristics and cut off parameters for the Marcellus shale and bounding strata for the gamma ray, photoelectric and bulk density logs that may be used as a type log for lithologic identification. Boyce also found that an increase in thorium in the gamma ray log response is associated with an increase in illite clay and these areas may be less responsive to hydraulic fracture stimulation.

Weicht (2015) used mechanical properties to identify brittle and ductile zones in the Marcellus shale. These zones were then coupled with high or low total organic carbon content. The analysis resulted in recommendation to target zones that fall in the high brittleness and high organic content range for best response to fracture stimulation and highest hydrocarbon potential. 
Hilliard (2015) classified rock brittleness using the brittleness average and brittleness index methods. Hilliard found that the brittleness average method should not be used when classifying brittleness of carbonates.

\subsubsection{Previous Marcellus Shale Production Analysis}

Hart (2014) used injection energy, fracture energy, radiated seismic energy, microseismic event magnitude and total proppant volume to assess the production of Marcellus shale wells in relation to microseismic events and 3D seismic analyses. Correlations were found include greater proppant volume is directly associated with a higher total production. However, the analyses between pumping parameters, microseismic events and 3D seismic structural analysis remain inconclusive.

Weicht (2015) used brittleness estimations and total organic content to estimate the fracability of two Marcellus shale wells. The fracability was analyzed in context of yearly production for the two wells but no correlations were found.

Industry, government and universities each contribute to our scientific understanding of unconventional hydrocarbon production. Through regional and site specific research, like this study, unconventional hydrocarbon production, large scale horizontal drilling and hydraulic fracture treatment may continue to progress.

\subsection{Dataset}

The study area is located in Harrison County West Virginia (Figure 1). This study will primarily focus on the Marcellus shale within two three-dimensional seismic surveys on the Eastern limb of the Wolf Summit Anticline (WSA). The WSA bisects Harrison County and 
trends northeast to southwest (Figure 1). The Goff 3D and Gepco 3D seismic surveys were donated to West Virginia University by Mountaineer Keystone LLC in November of 2014 for this research study.

The two seismic surveys span 7.8 miles in central Harrison County West Virginia (Figure 1). The Goff 3D seismic survey is $11.37 \mathrm{mi}^{2}\left(4.389 \mathrm{~km}^{2}\right)$ and contains 177 inlines oriented northsouth and 148 crosslines oriented west-east. The Gepco 3D seismic survey is located just to the southeast of the Goff 3D seismic survey. The Gepco 3D seismic survey is $9.03711 .37 \mathrm{mi}^{2}(3.489$ $\mathrm{km}^{2}$ ) and contains137 inlines oriented northwest-southeast and 152 crosslines oriented northeastsouthwest.

The coordinate system for the surveys is US State Plane NAD 27 West Virginia North 4701. The bin spacing is 110 feet. The record length was four seconds at 2001 samples per trace with a 0.002 second sample interval. The surveys were processed in March of 2010 by processing contractor Sterling Seismic Services Ltd. and loaded into Kingdom ${ }^{\circledR}$ by Petroleum Development Corporation in July of 2010. 
A.

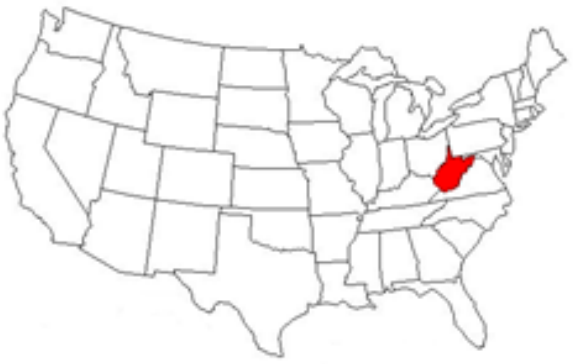

B.
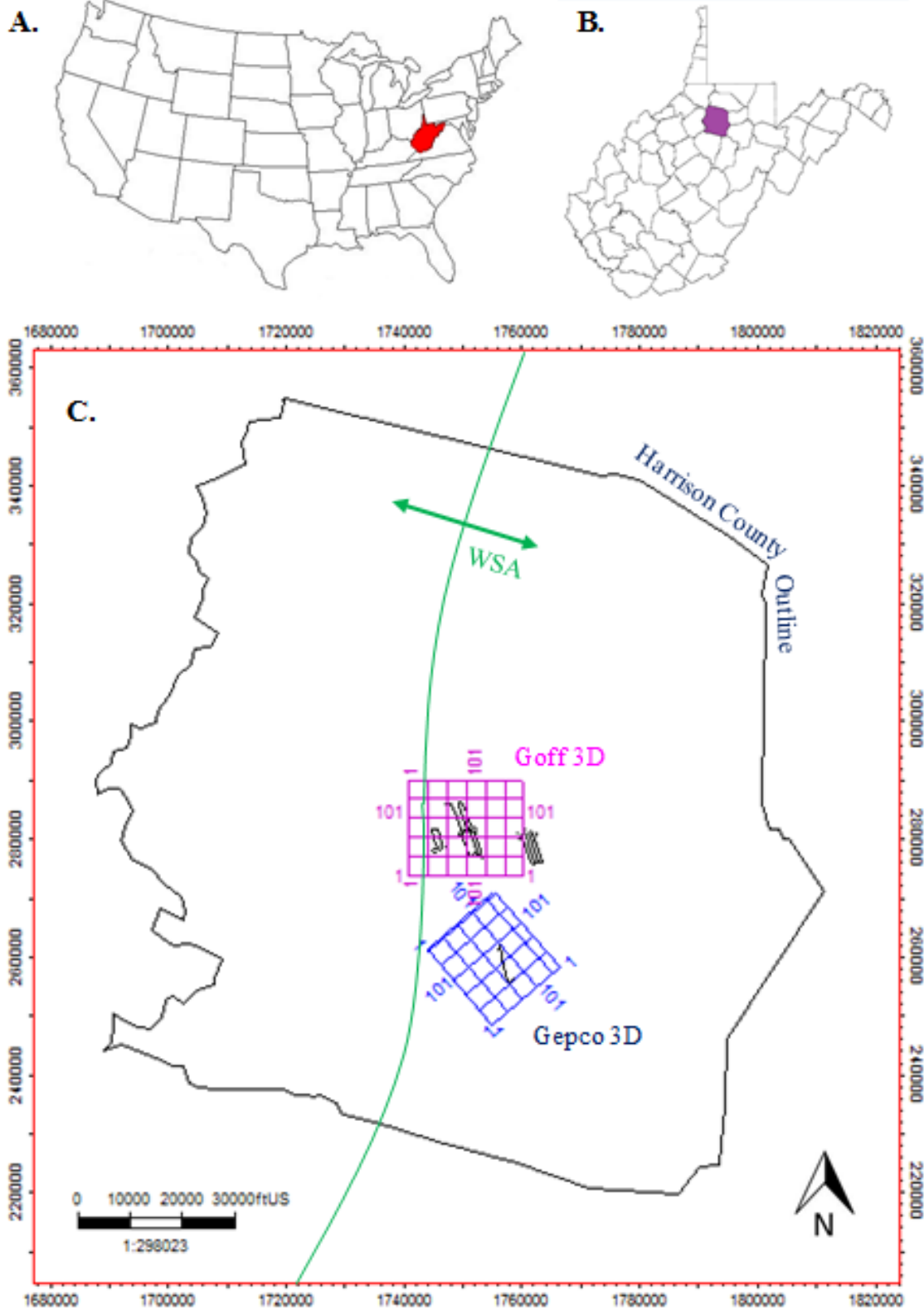

Figure 1: Location map for the seismic datasets in Harrison County West Virginia. A) Location of West Virginia in the United States. B) Locations of Harrison County in West Virginia. C) Outline of Harrison County, the approximate location of the Wolf Summit anticline, the Goff 3D seismic survey, the Gepco 3D seismic survey and fourteen horizontal wells. 


\section{GEOLOGIC SETTING}

\subsection{Appalachian Basin}

The Appalachian basin is a foreland basin in the eastern United States that extends from

New York to Georgia. The Appalachian basin is one of the largest basins in the United States

(Figure 2). The age of rocks in the Appalachian basin ranges from Early Cambrian to Early

Permian. West Virginia lies within the lower central portion of the Appalachian basin with geology dominated by sequences of sandstone, shale, limestone and coal (Figure 3).

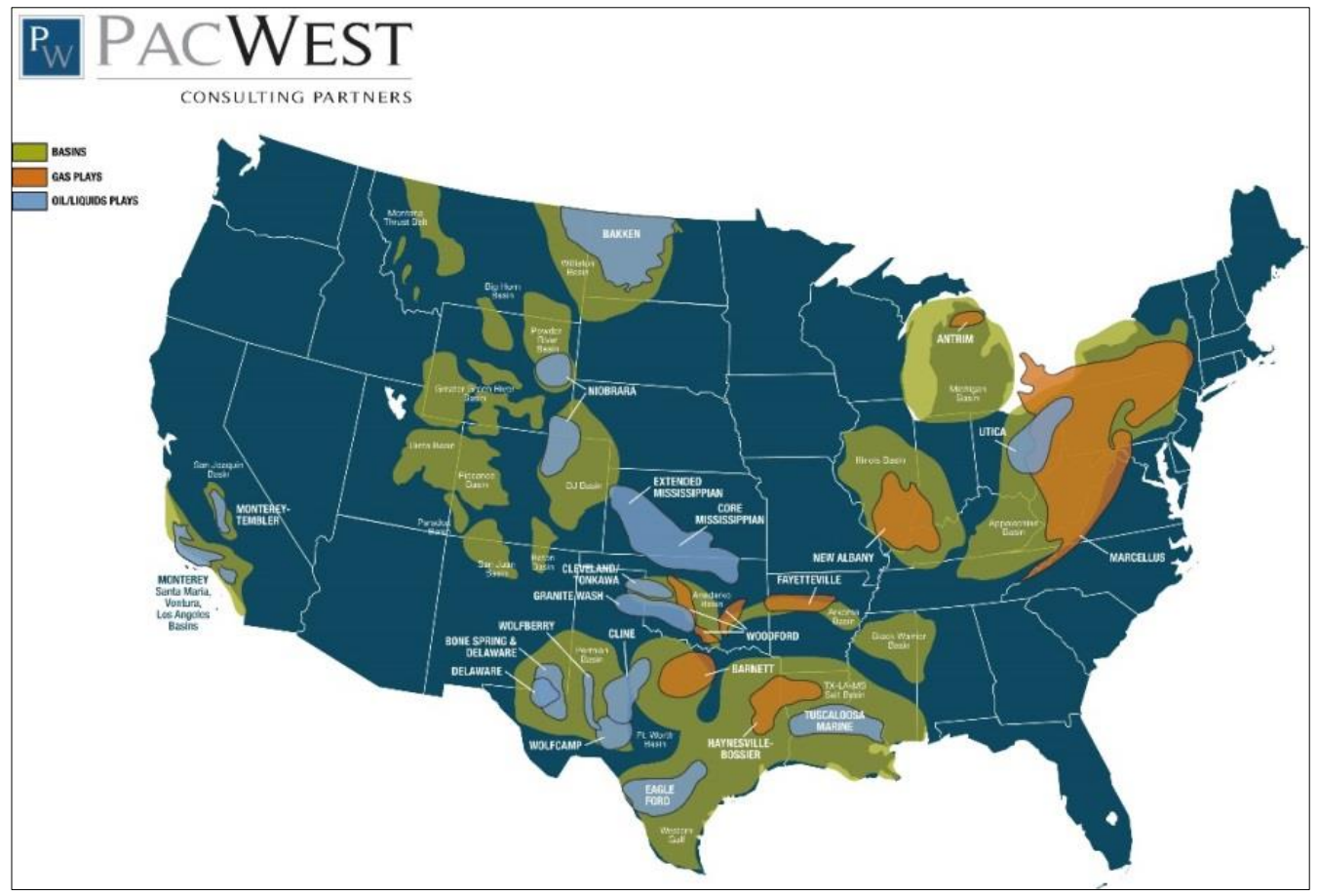

Figure 2: Sedimentary basins of the lower 48 states in the United States shaded in green. Gas plays are shaded in orange. Oil and higher chain hydrocarbon plays are shaded in blue. This image depicts the Appalachian basin containing the largest gas play in the United States (Pac West Consulting Partners, 2014, http://pacwestcp.com/2012/07/pacwestpublishes-updated-shaleunconventional-play-maps/). 


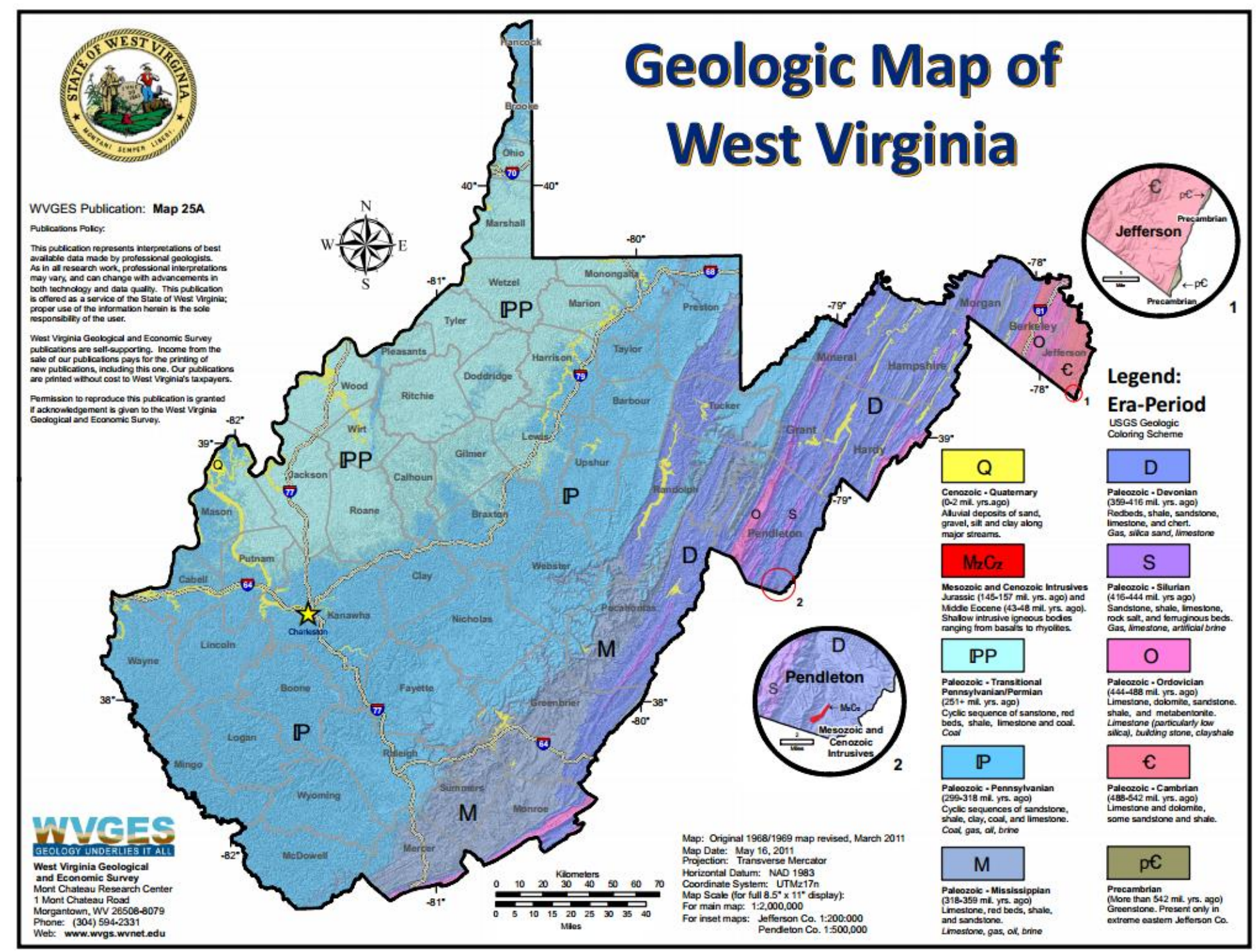

Figure 3: Geologic map of West Virginia (West Virginia Geologic and Economic Survey, 2011, http://www.wvgs.wvnet.edu/). Harrison County is in the north central portion on the state and contains rocks of Pennsylvanian and Permian age. 


\subsubsection{Orogenic Events}

Four orogenic events resulted in the formation of the Appalachian Orogen- the Cambrian Ordovician failed rifting event followed by the Taconic, Acadian and Alleghanian orogonies. The Cambrian-Ordovician rifting produced basement faults from extension (Shumaker and Wilson, 1996) which were reactivated during later tectonic events (Wilson, 2000).

The Taconic orogeny took place during the Middle Ordovician. During the Taconic orogeny, the Iapetian oceanic continent began to subduct underneath the North American continental plate (Faill, 1997). The Taconic Island Arc was accreted onto the eastern edge of the North American craton creating the Taconic Mountains (Figure 4, H). The Taconic orogeny was followed by a period of rest with no major tectonic activity until the Late Devonian with the Acadian orogeny.

The Acadian Orogeny is marked by an island arc continent collision of the North American craton named Laurentia with the Avalonian Island arc(s). The collision(s) initiated a sequence of events where the previously deposited rocks were subjected to deformation, plutonism, metamorphism, and uplift (Naylor, 1971). The Acadian orogeny produced the Catskill delta and is interpreted to have developed through four tectophases of various Avalonian terrane collisions (Ettensohn, 2004). The Avalonian terrane(s) accreted onto Laurentia creating the Acadian Mountains. Subsequent erosion formed the Catskill delta containing the Marcellus shale (Image J, Figure 4). The entire Catskill delta thickens toward the east and thins towards the west (Figure 5). The Marcellus shale was deposited during the second tectophase of the Acadian orogeny (Figure 5).

The final orogenic event on the east coast of the North American craton was the Alleghanian orogeny. The Alleghanian orogeny began in the Late Mississippian as a result of the 
African and North American continent-continent collision forming the supercontinent Pangea

(Figure 4, K). The Alleghanian orogeny resulted in the complex fold and thrust belt of the present day Appalachian Mountains and deformation of the Marcellus shale. Finally, convergence ended and rifting began at the modern day Mid-Atlantic Ridge (Figure 4, L).
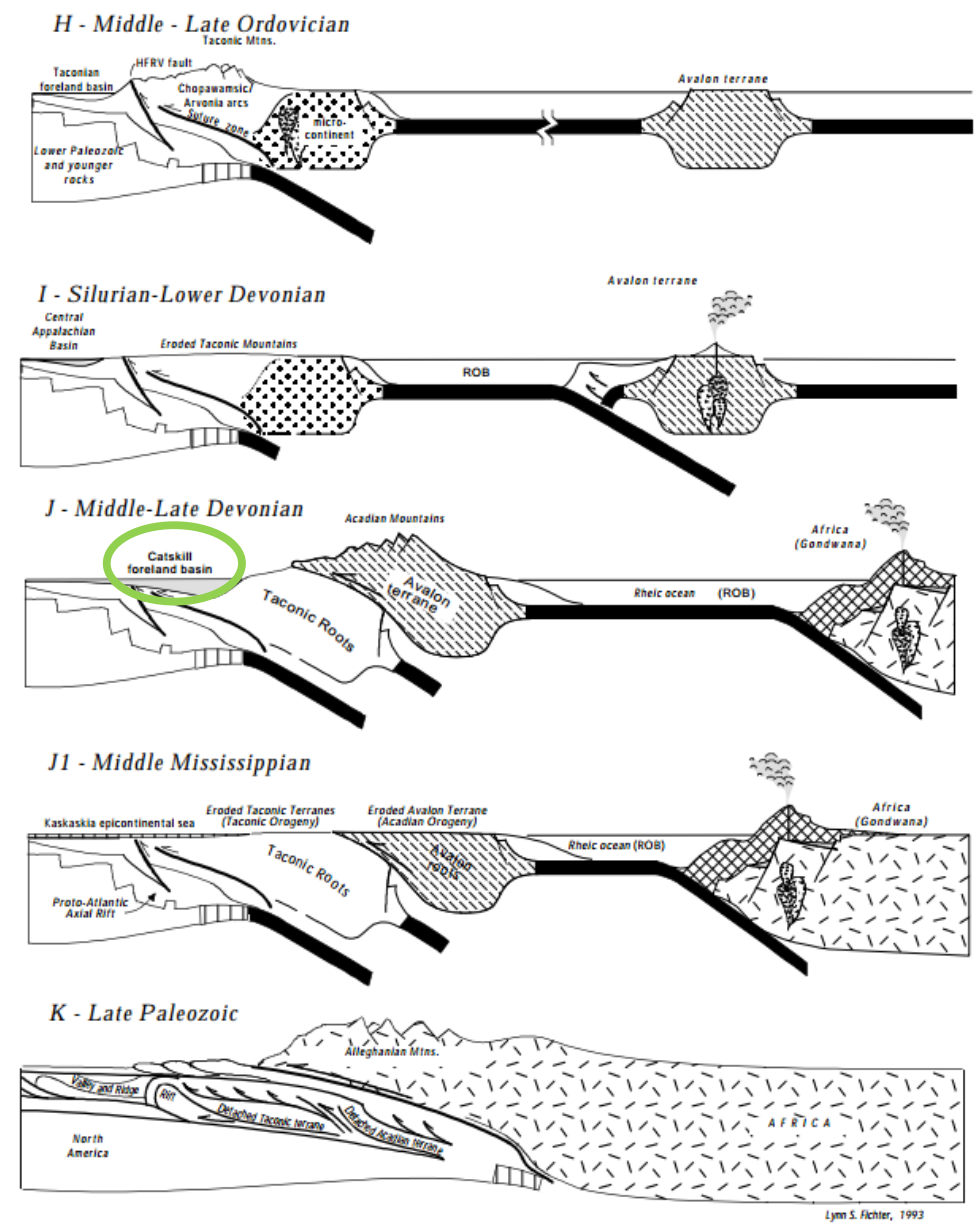

L - Triassic-Lower Jurassic

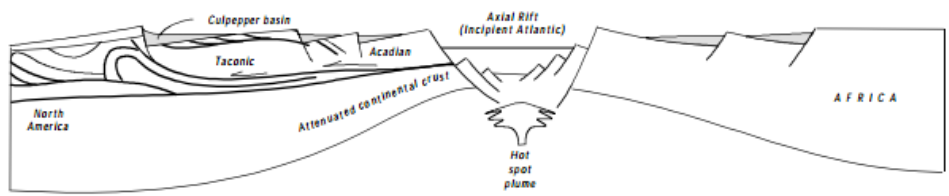

Figure 4: Depiction of past orogonies that formed the Appalachian Mountains and subsequent Appalachian basin (Fichter, 1993). During the Middle Devonian the Marcellus shale was deposited as an organic rich mud in the Catskill foreland basin circled here in green. 


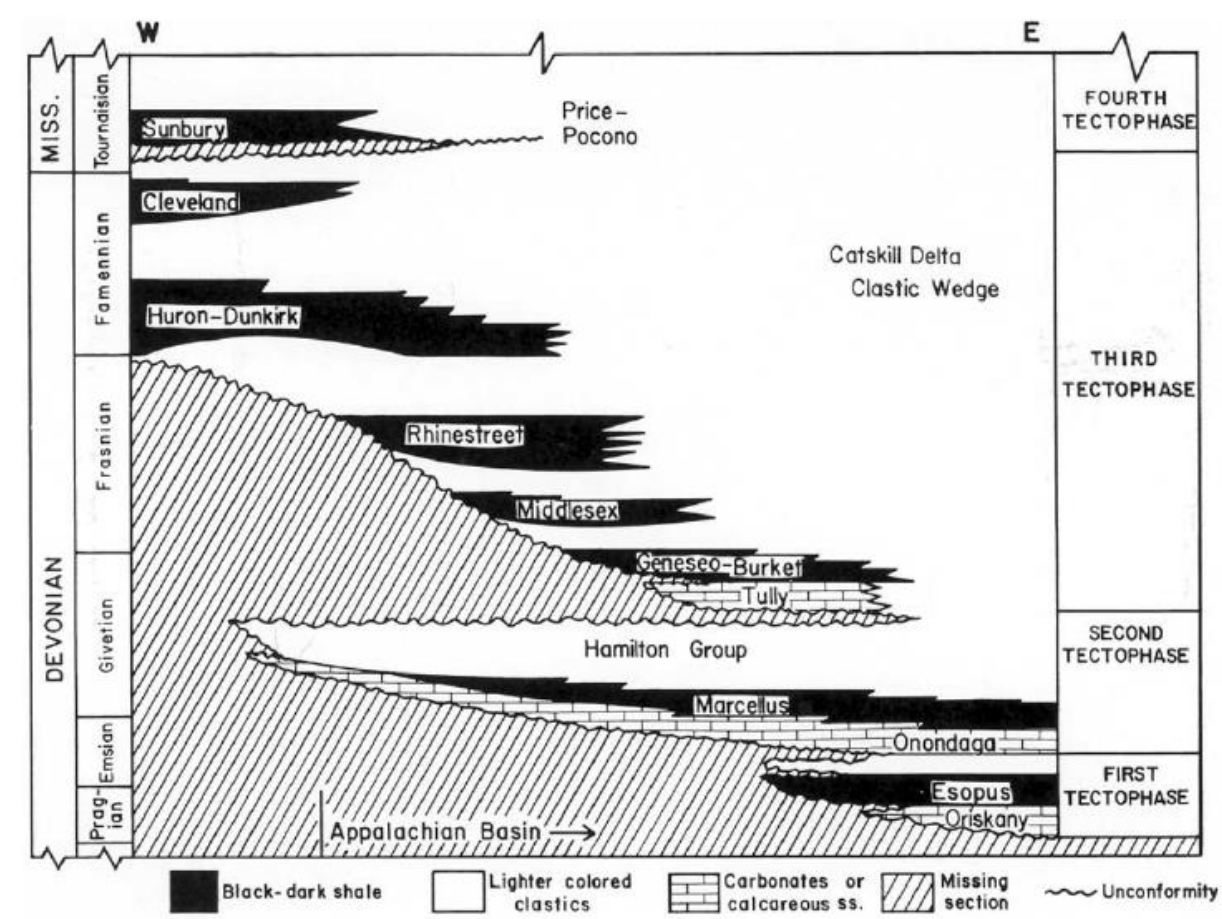

Figure 5: The Catskill delta W-E stratigraphic section in the Appalachian basin (Ettenshon, 2004). The Marcellus shale was deposited during the Middle Devonian. Figure is not to scale.

These orogenic events contributed to the development of the Taconic, Acadian and Alleghanian Mountains. The foreland basin to the west of the present day Appalachian Mountains experienced sedimentation from the erosion of these mountains. The complex folds and faults that developed during the Alleghanian orogeny created numerous hydrocarbon traps making the Appalachian basin an early target for oil and gas exploration.

\subsubsection{General Stratigraphy}

Stratigraphy of interest for this study are depicted in Figure 6. The Marcellus shale is targeted for hydrocarbon production through hydraulic fracture stimulation treatment. The upper and lower limestones, the Tully and Onondaga respectively, serve as hydraulic fracture treatment barriers to help contain hydraulic stimulation during Marcellus shale production (Figure 6). 


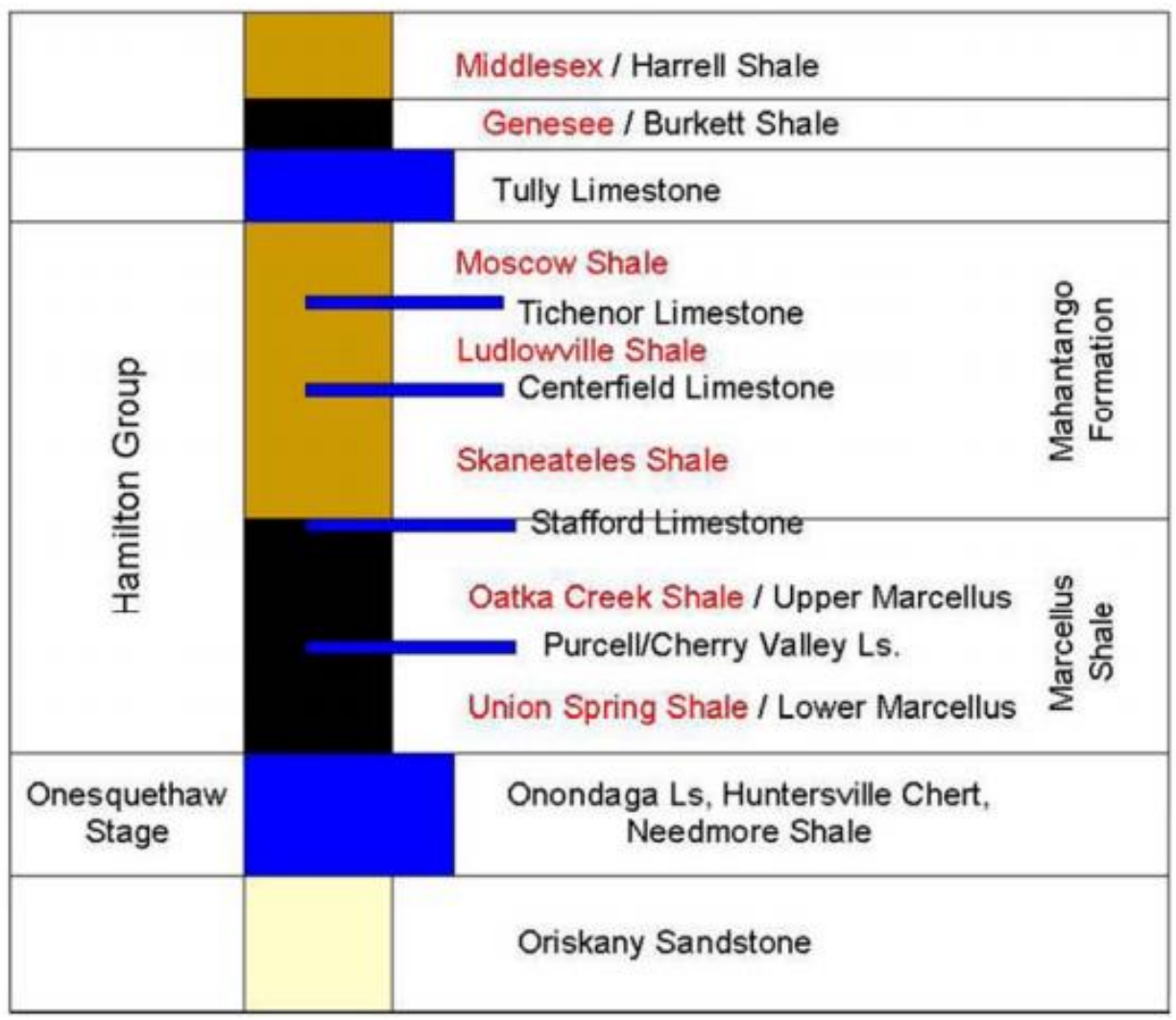

Figure 6: Simple stratigraphic column of the Marcellus shale and bounding strata (Wrightstone 2009). Brown indicates shale, black indicates black shale, blue is limestone and yellow is sandstone. Red indicates New York terminology.

\subsection{Structural Setting}

In northern West Virginia, the Appalachian basin corresponds with the Allegheny plateau. The Allegheny plateau is a moderately deformed terrain characterized by thin-skinned structures of Alleghanian age divided into the 'low' and 'high' plateau regions (Gwinn, 1964). Towards the east, the Allegheny plateau reaches the Allegheny structural front of the Valley and Ridge province. In northern West Virginia, the Rome trough underlies the Allegheny plateau in the low plateau region that encompasses the Arches Fork and Wolf Summit anticlines (Figure 7). The Rome trough is a northeast trending graben extending to basement (Kulander and Ryder, 2005) buried beneath at least 20,000 feet of Paleozoic strata (Shumaker and Wilson, 1996). 


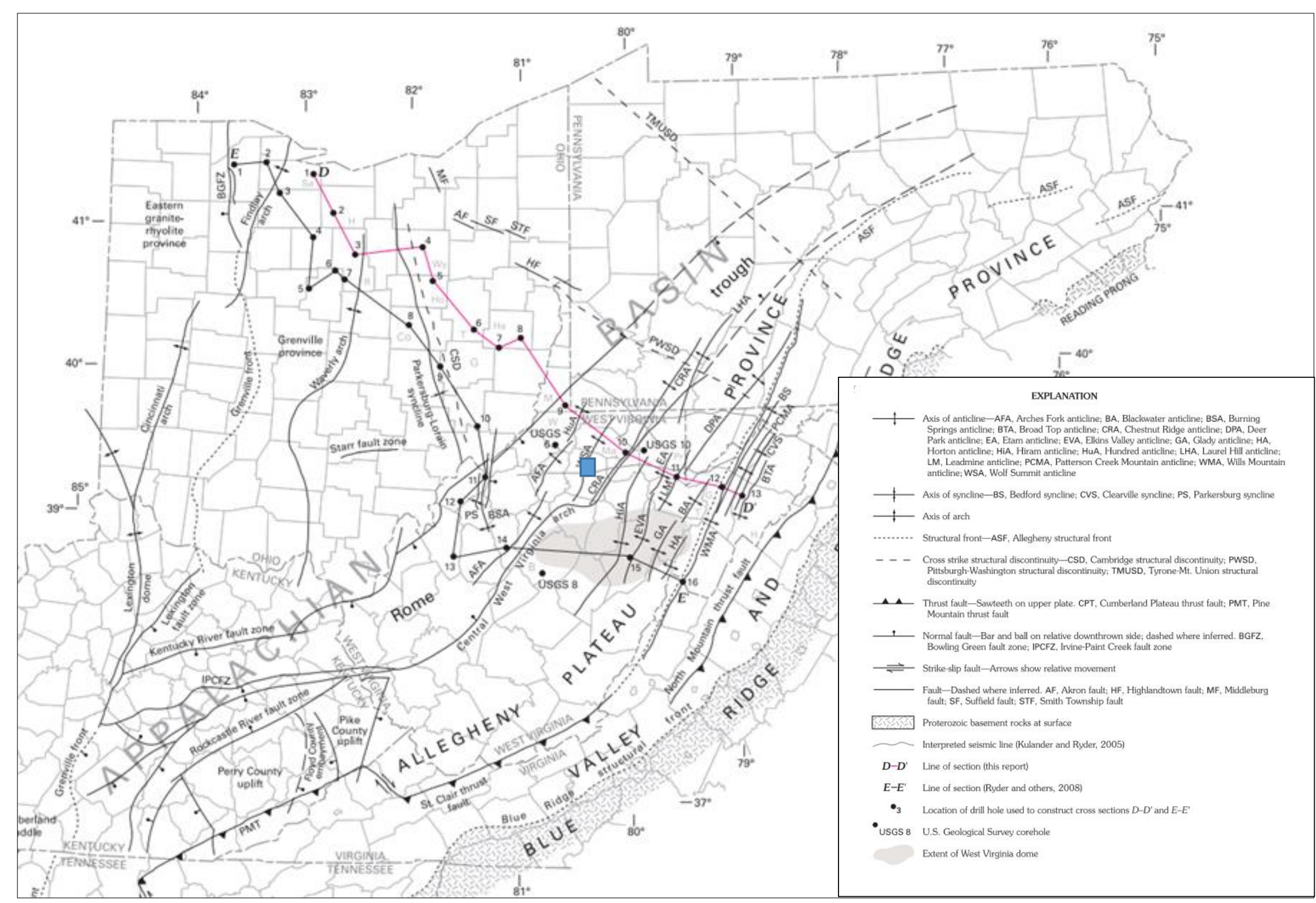

Figure 7: The structural geology of the Appalachian basin adapted from Ryder et al. 2009 Geological Survey publication. Harrison County lies over the Rome trough. The Wolf Summit anticline (WSA) directly bisects the county Northeast-Southwest. Blue square denotes approximate location of Goff 3D and Gepco 3D surveys between WSA and the Chestnut Ridge anticline (CRA). 


\subsubsection{Contemporary Stress Field}

Present day stress orientations vary across the Appalachian basin. The major structural trend is a northeast orientation following the Allegheny Mountains. Contemporary stress orientations are plotted in the World Stress Map Project (Figure 8) (Heidbach et al., 2008). The original sources are from 1972 through 1990 before the large scale implementation of horizontal drilling, hydraulic fracture treatment and formation image logging started in the late 2000's (Beard, 2011; Brown, 2013; Zagorski et. al, 2012). Since production of the Marcellus shale began in the region stress data may be added in areas where data control is low such as in northeastern West Virginia and southwestern Pennsylvania (see Table 4).

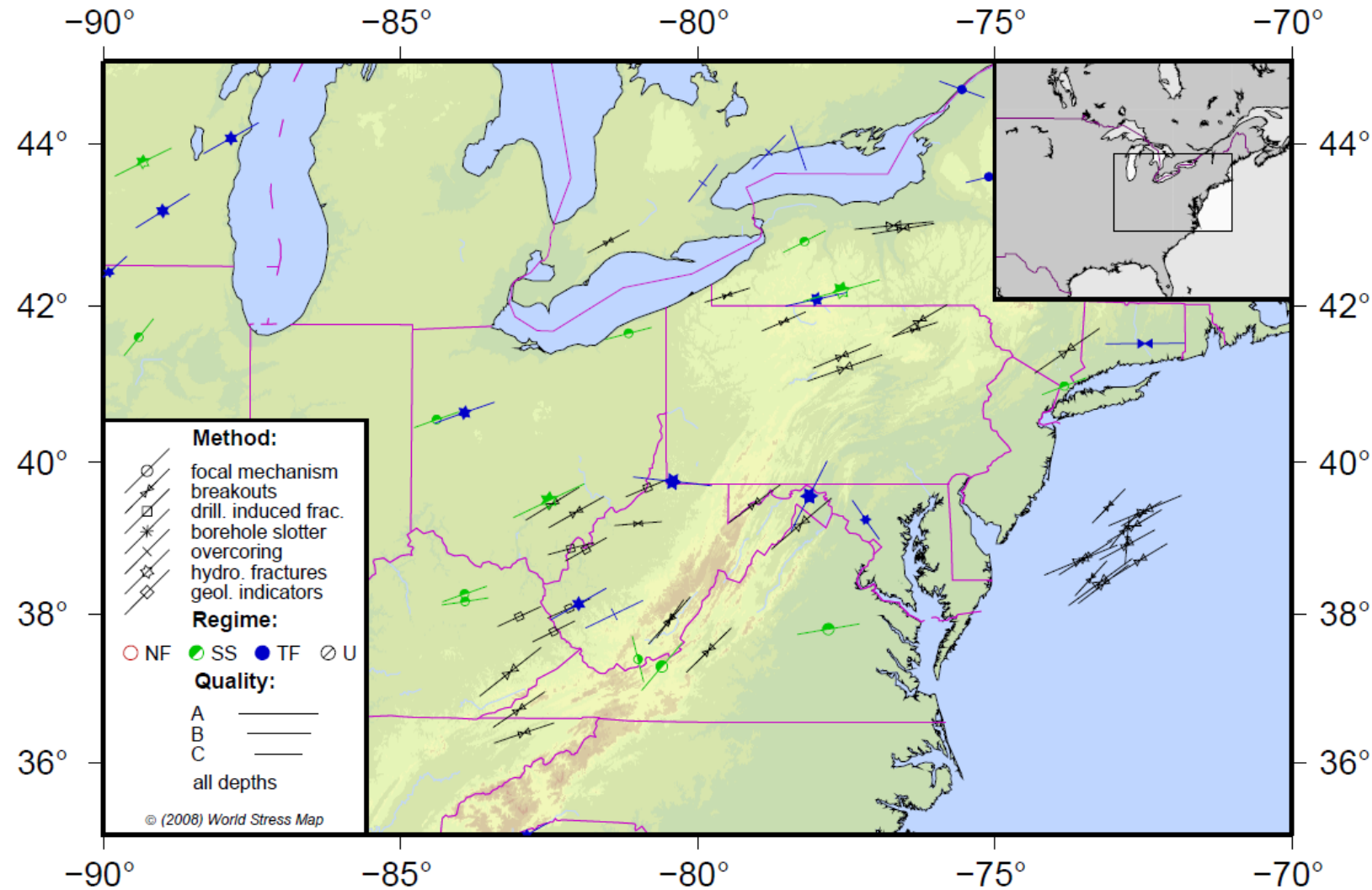

Figure 8: Map showing contemporary stress orientations in the Appalachian basin (Heidbach et al., 2008). The symbol denotes the measurement method for the data point, the color of the symbol denotes which stress regime the data point is in and the length of the line denotes the quality of the data point. Only A, B and C quality data points are used (Zoback and Zoback, 1991). 


\subsection{Marcellus Shale}

The Marcellus shale is a Middle Devonian primary source rock in the Appalachian basin as well as an unconventional reservoir rock. Marcellus shale is produced through the implementation of horizontal drilling and hydraulic fracture stimulation. Depth and thickness of this shale play are two parameters used to assess areas for possible production.

The Marcellus shale is relatively shallow in New York and is deepest in central Pennsylvania reaching a maximum depth of over 9000 feet (Figure 9). The Marcellus shale thickens to the east (Figure 4, Figure 10) and has a thickness between 50-150 feet in Harrison County West Virginia (Figure 10). Log analysis (Chapter 3) of the Goff \#55 well indicates a depth top of the Marcellus shale at -7129 feet measured depth. At this well the Marcellus shale is 106 feet thick and contains an organic rich zone 23 feet thick known as the lower Marcellus.

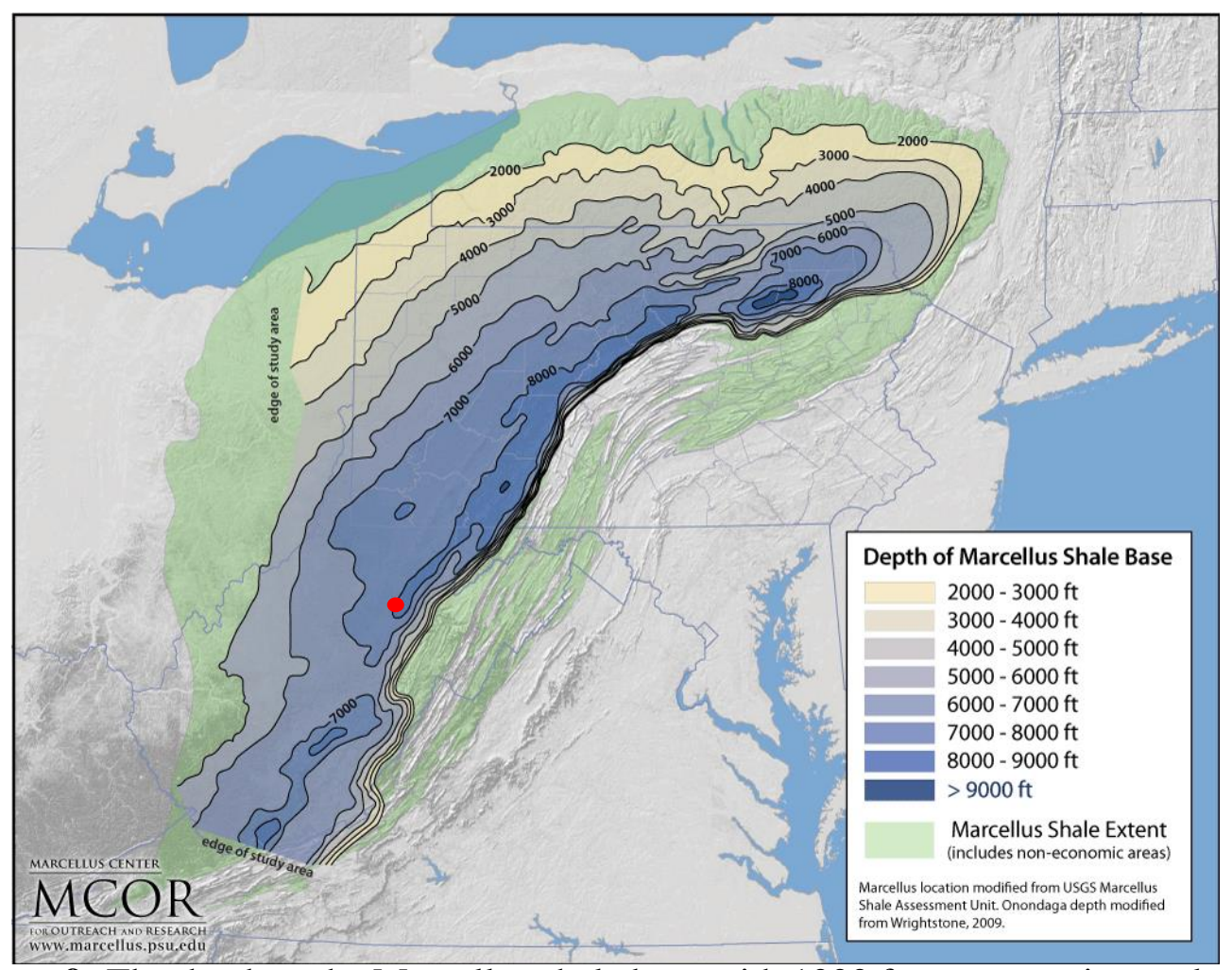

Figure 9: The depth to the Marcellus shale base with 1000 foot contour interval and Marcellus shale extent in green (Marcellus Center for Outreach and Research, 2008). In Harrison County the Marcellus shale is 7000-8000 feet deep. Approximate location of study well marked by red circle. 


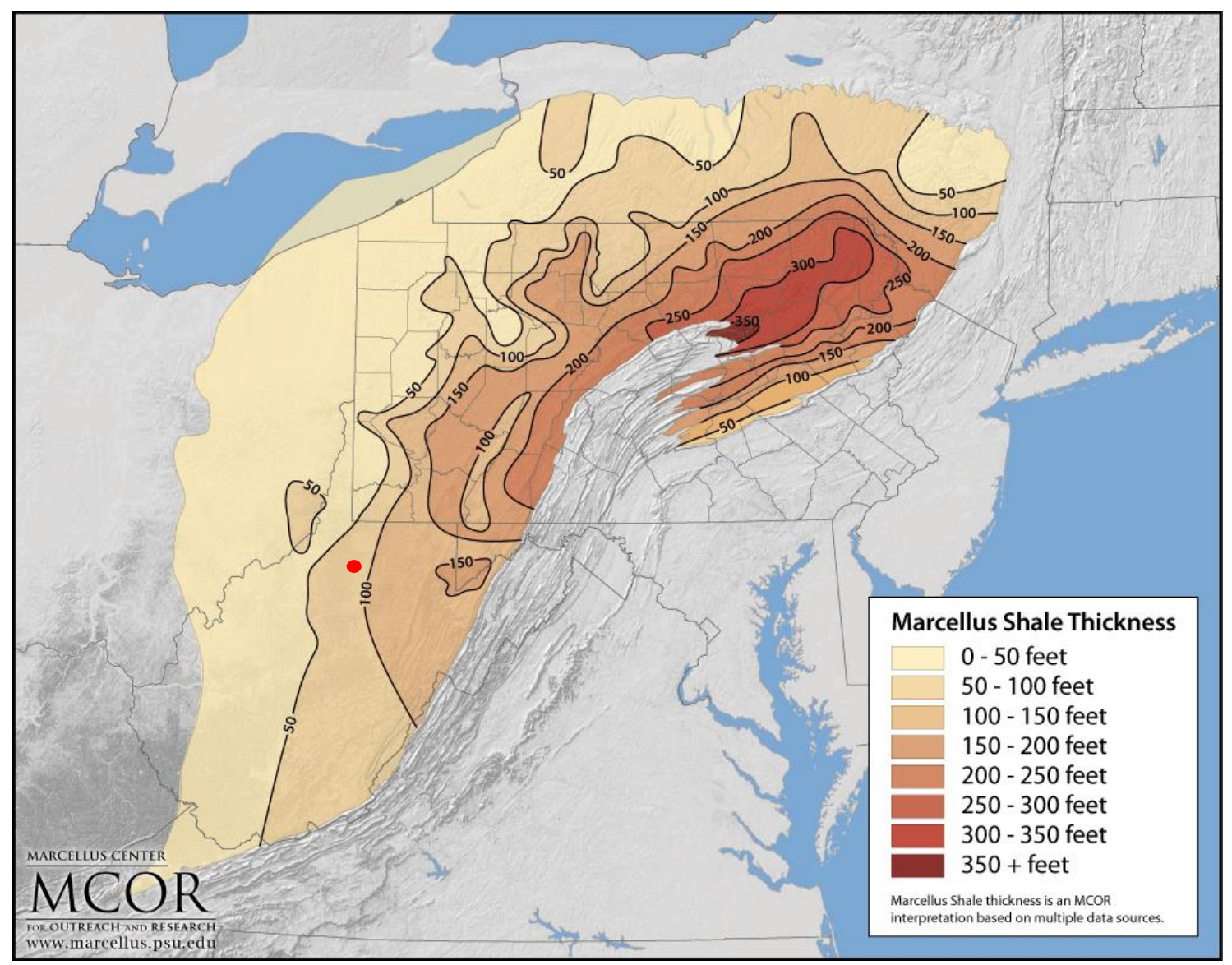

Figure 10: The thickness of the Marcellus shale with 50 foot contour interval (Marcellus Center for Outreach and Research, 2008). In Harrison County the Marcellus shale is between the 50 foot and 150 foot contour intervals. Approximate location of study well marked by red circle.

\subsubsection{Depositional Environment}

The Marcellus shale was deposited during the Middle Devonian in what is now the Appalachian basin. Paleomagnetic data indicates that the Appalachian basin was located twenty degrees south of the equator during the Middle Devonian (Kent, 1985). The paleoenvironment of the study area was a shallow epicontinental seaway (Figure 11) where a series of transgressions and regressions occurred depositing the Marcellus shale and the thin limestone layers that separate the upper, middle and lower Marcellus (Blakey, 2008). Organic rich mud of the 
Marcellus shale was subjected to burial, basin subsidence and thermal maturation which created the hydrocarbon source for present day hydrocarbon production (Faill, 1997; Castle, 2001 and Ettensohn 2004).

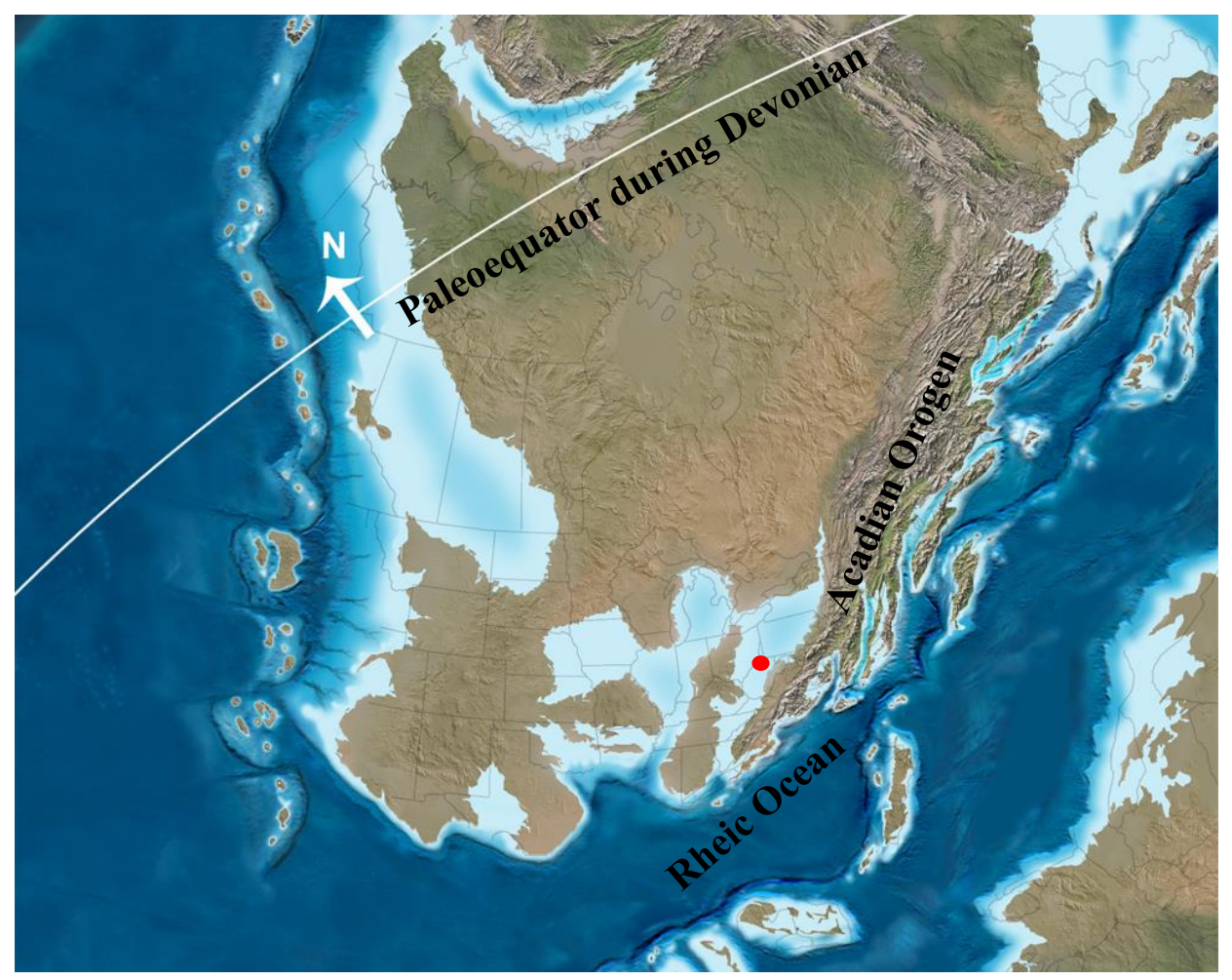

Figure 11: Paleogeographic map of the United States during the Devonian (modified from Blakey, 2008). The future United States is outlined. During the Devonian the United States are located below the paleo equator (marked in this image by a white line). The study area is marked by a small red circle in the shallow epicontinental sea. 


\section{LITHOLOGIC ANALYSIS}

\subsection{Marcellus Shale Overview}

\subsubsection{Marcellus Shale Characteristics and Type Log}

The Marcellus shale and bounding strata are identified by their petrophysical properties including gamma ray, photoelectric index, bulk density and total organic carbon (TOC) content (Table 1). These characteristic values are based on multiple borehole geophysical log and core studies (Repetski at al., 2005; Milici and Swezey, 2006; Boyce, 2010).

\begin{tabular}{|l|c|c|c|c|}
\hline $\begin{array}{l}\text { Stratigraphic } \\
\text { Unit }\end{array}$ & $\begin{array}{c}\text { Gamma Ray } \\
(\text { API) }\end{array}$ & $\begin{array}{c}\text { Photoelectric Index } \\
\text { (Barnes/electron) }\end{array}$ & $\begin{array}{c}\text { Bulk Density } \\
\text { (gm/cc) }\end{array}$ & $\begin{array}{c}\text { Total Organic } \\
\text { Content } \\
\text { (weight \%) }\end{array}$ \\
\hline Tully Limestone & Clean (30-110) & Approx. 5 & 2.71 & $<1$ \\
\hline $\begin{array}{l}\text { Mahantango } \\
\text { Shale }\end{array}$ & $<200$ & N/A & $>2.55$ & $>1$ \\
\hline $\begin{array}{l}\text { Purcell } \\
\text { Limestone }\end{array}$ & $<200$ & Approx. 5 & 2.71 & $<1$ \\
\hline $\begin{array}{l}\text { Marcellus Shale } \\
\text { Onondaga }\end{array}$ & $>200$ & N/A & $<2.55$ & $>3$ \\
\hline $\begin{array}{l}\text { Clean }(30-110) \\
\text { Limestone }\end{array}$ & Approx. 5 & 2.71 & $<1$ \\
\hline
\end{tabular}

Table 1: Geophysical log reference values of gamma ray, photoelectric index, bulk density and TOC of the Marcellus shale and bounding strata (Repetski at al., 2005; Milici and Swezey, 2006; Boyce, 2010).

A type log is a well log that has been "singularly selected as being particularly illustrative" of the typical log response of the subsurface geology being studied (Indiana Geological Survey, 2015). A Marcellus shale type log for Harrison County West Virginia developed from the Goff \#55 well as part of this study. Figure 12 illustrates the typical petrophysical characteristics of the Marcellus shale in this study area. 
GOFF \#55

API: 47033051606000

Harrison County, WV

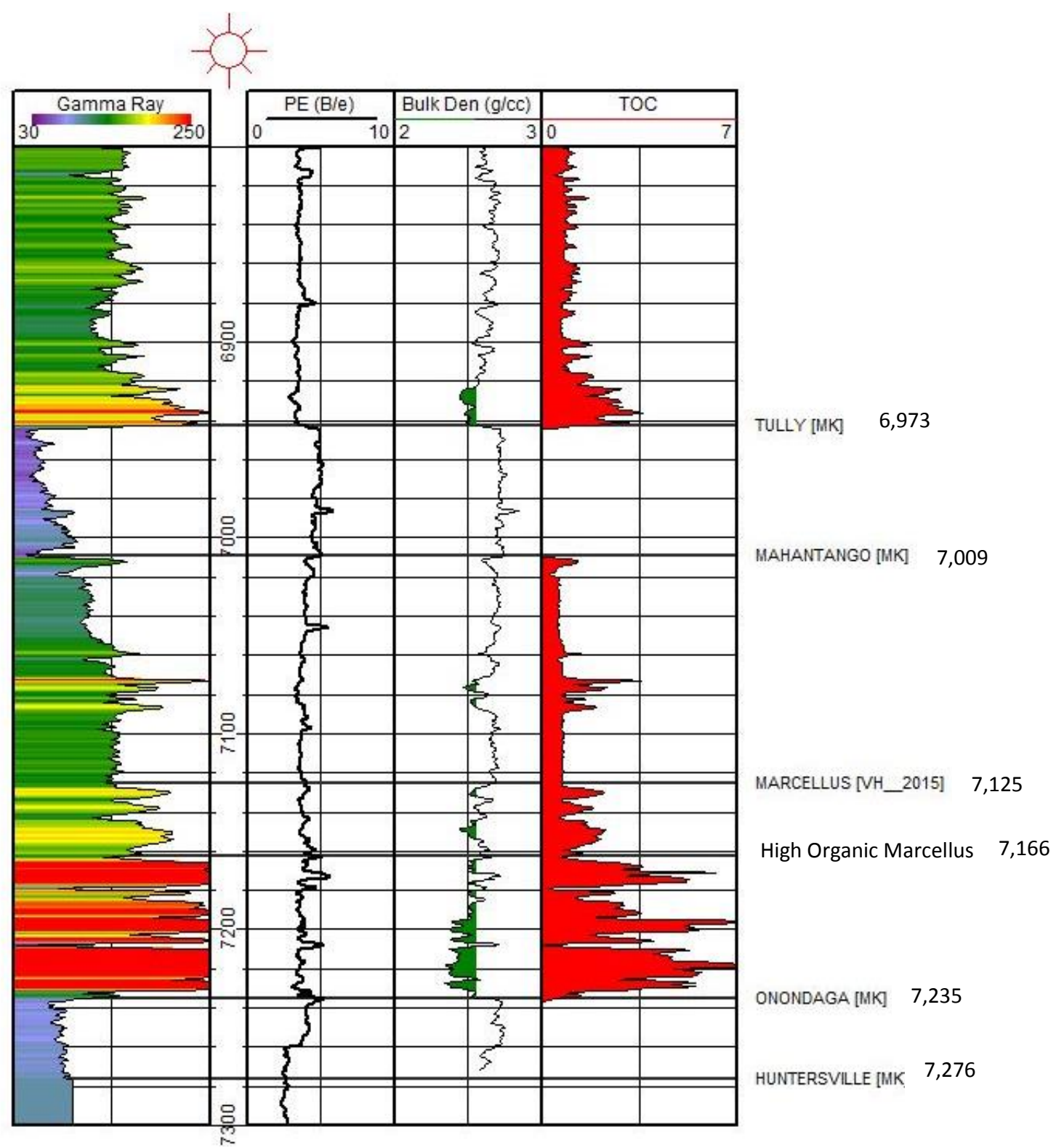

Figure 12: Type log for the Upper to Middle Devonian strata in the study. Geophysical characteristics of the Marcellus shale are a gamma ray response of over 200 API, a photoelectric index value less than five Barnes/electron, a bulk density less than $2.55 \mathrm{~g} / \mathrm{cc}$ and a total organic content of greater than three percent. 


\subsection{Goff \#55 Well Log Interpretation}

The top and base of the Marcellus shale were picked at -7129 and -7230 feet measured depth respectively (Figure 13). The Marcellus top pick is based on high gamma ray, an increase in total organic content (TOC), bulk density less than $2.55 \mathrm{~g} / \mathrm{cc}$ and velocity less than 11,000 $\mathrm{ft} / \mathrm{sec}$. The Marcellus shale top pick corresponds to the top pick of Hilliard (2015) which was picked at -7125 feet measured depth. Hilliard's (2015) top pick was based on core studies with a sequence stratigraphic framework and "where TOC dropped to $0 \%$ and bulk density increased to $2.65 \mathrm{~g} / \mathrm{cc} "$ (Hilliard, 2015, p.13).

The density and velocity cutoffs used to establish the Marcellus shale top pick in this study were based on characteristic changes in well log response from the overlying Mahantango shale transitioning into the Marcellus shale. The shift to relatively lower velocity and lower density marks the beginning of the Marcellus shale, marked with red circles in Figure 14. Analyzing the location of the Marcellus shale in the context of density and sonic log response is important for the relationship with seismic reflectivity and seismic character, see sections 4.1: Synthetic Seismogram and 4.4 Acoustic Logs Response and Seismic Character.

The Purcell limestone and Cherry Valley limestone are two thin limestone beds within the Marcellus shale that exhibit low gamma ray signature and low total organic content. These limestone beds divide the Marcellus shale into the upper, middle and lower Marcellus members.

The base of the Marcellus shale, or top of the Onondaga limestone, is picked at -7235 feet measured depth which exactly matches Hilliard's (2015) basal pick for the Marcellus shale. The entire Marcellus shale is 106 feet thick at the study well. The start of the organic rich shale was 
also picked for the top of the Marcellus shale in this study, labeled 'High TOC Marcellus'. This zone marks where total organic content begins to average above three percent, weight percent. The pick for the high organic rich region is at -7166 feet measured depth (Figures 13 and 14). The highest organic content region or 'hot spot' is the lower Marcellus shale below the Cherry Valley limestone. The lower Marcellus shale is 23 feet thick with an average of 4.7 weight percent TOC (Figures 13 and 14). The lower Marcellus shale is generally the location for landing a horizontal well and performing hydraulic fracture stimulation treatment. This zone is discussed in context of mineralogy, brittleness and seismic response in sections 3.2.1: Mineralogy, 3.2.2: Mechanical Stratigraphy and 4.4 Acoustic Logs Response and Seismic Character.

Compositional log analysis provides insight into the Marcellus shale depositional enviroment. The compositional logs plotted in Track 4 are colored yellow for quartz feldspar and microcline, blue for calcite and dolomite and grey for all clay types (Figures 13 and 14). The mineralogy is further discussed in Section 3.2.1: Mineralogy and related to the brittleness index in section 3.2.2: Mechanical Stratigraphy. 


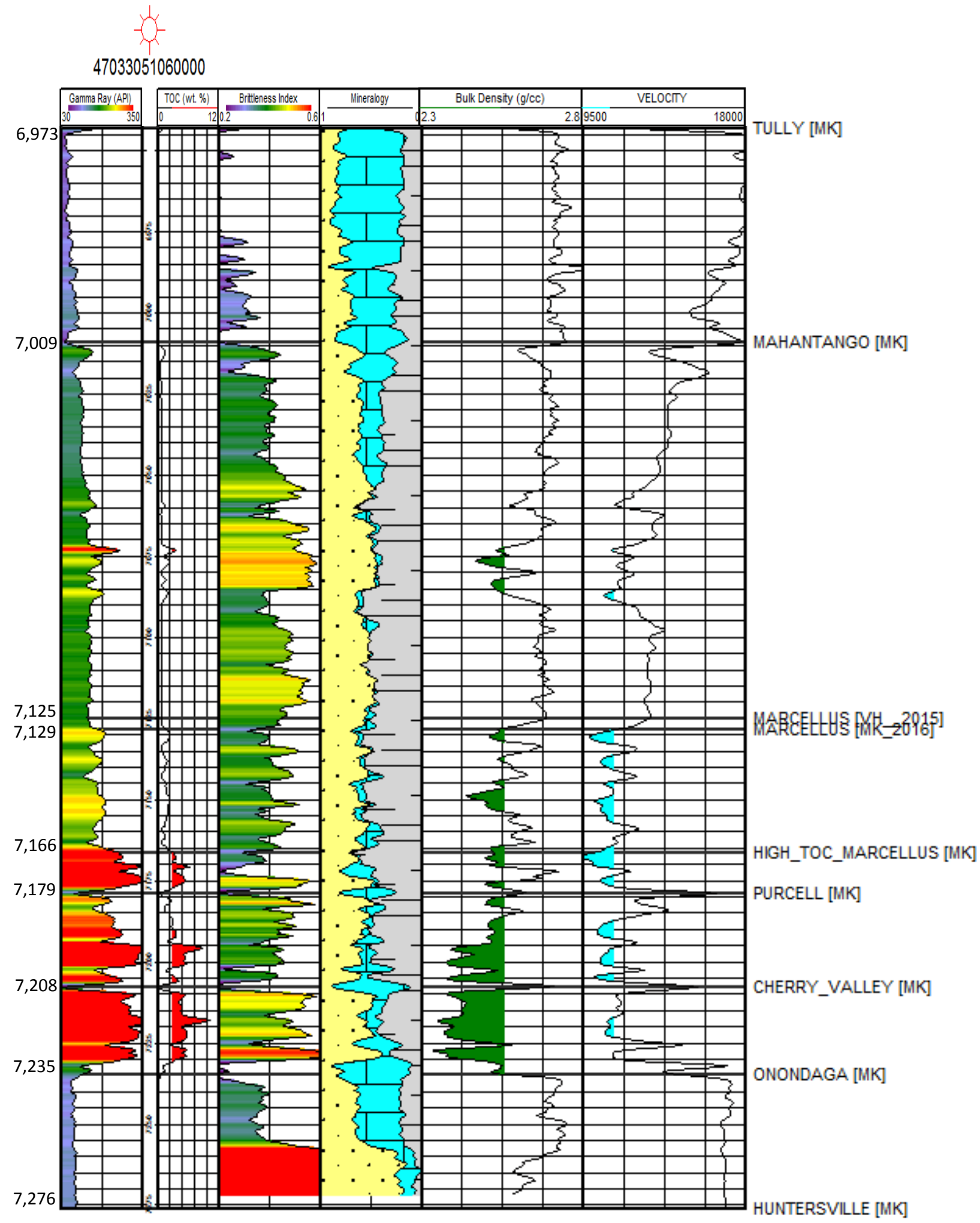

Figure 13: Goff \#55 well with gamma ray, total organic content, brittleness index, compositional logs, bulk density and velocity to show characteristic changes in these $\log$ responses from the Tully limestone through the Onondaga limestone. 


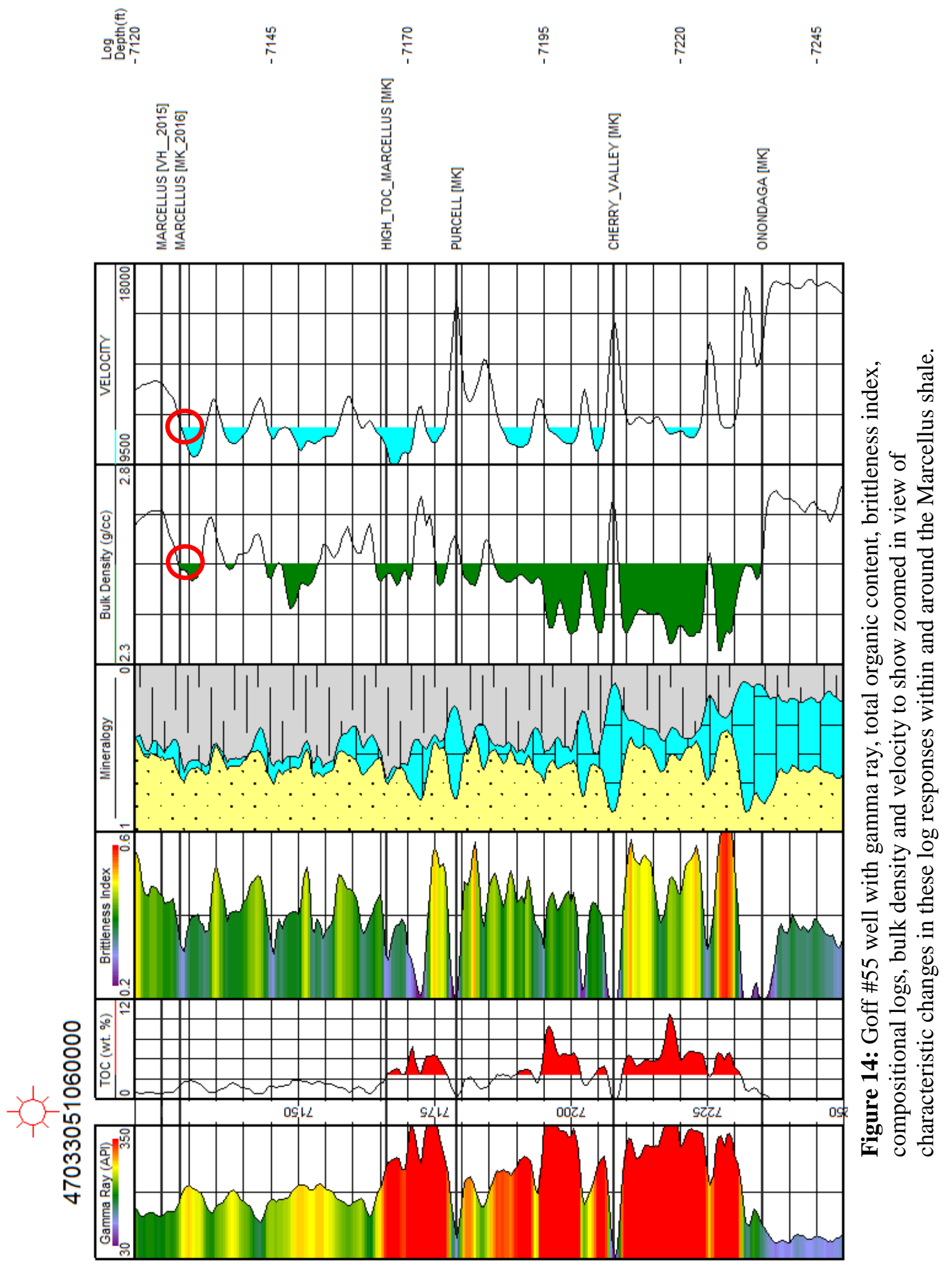




\subsubsection{Mineralogy}

To further assess the relatopnship between mineralogy and TOC the mineralogy logs are plotted on ternary diagrams. In this case the mineralogy logs are Schlumberger's SpectroLith ${ }^{\circledR}$ gamma ray spectroscopy logs reported in weight percent. The three mineralogy end members are quartz/feldspar/microcline (QFM), calcite and dolomite (Carbonate), and all clay types (Clay). A ternary diagram depicts the percentages of each mineralogy end member and the classification of the rock based on these three geophysical logs (Figure 15).

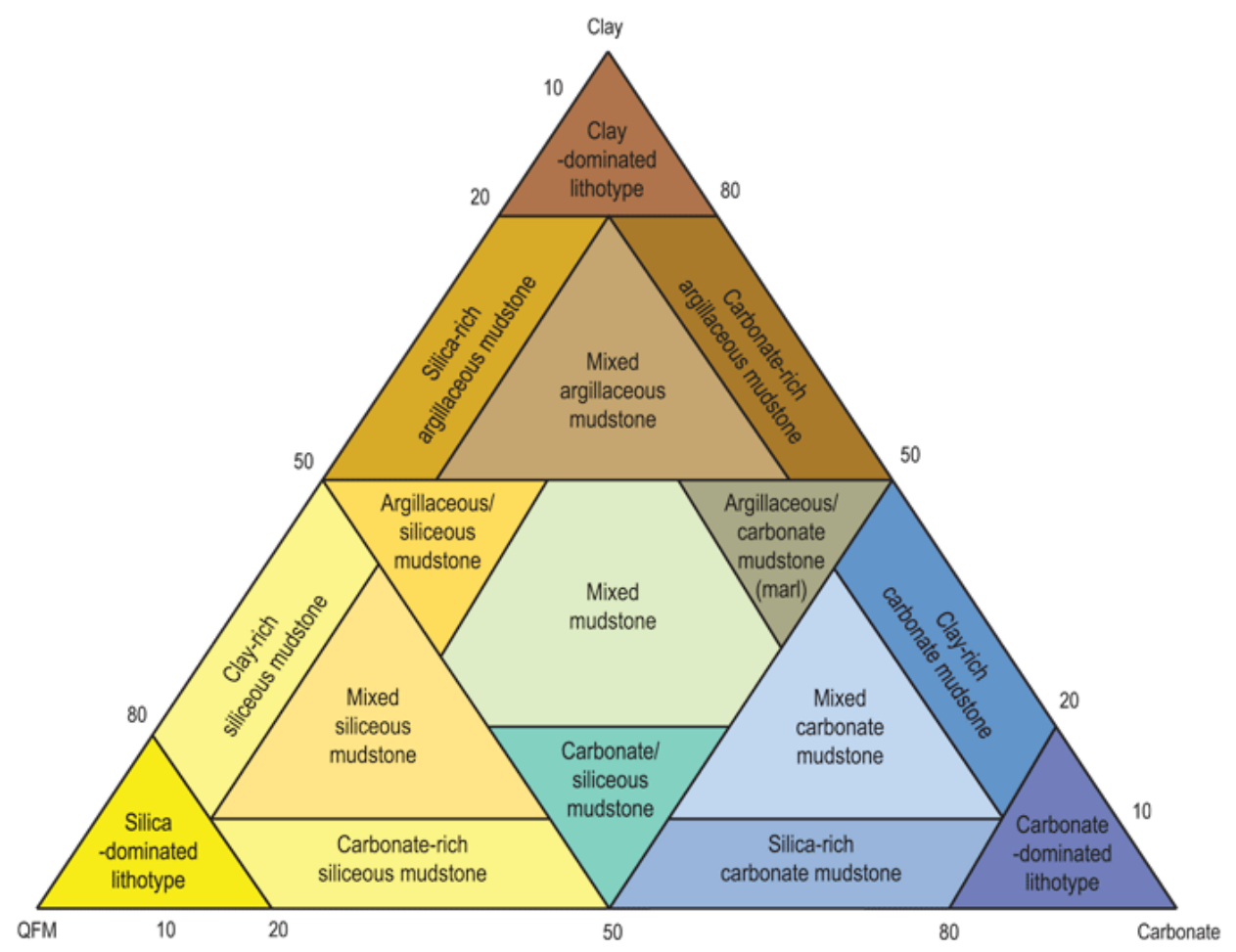

Figure 15: Schlumberger (2016) ternary diagram to classify rocks based on three major mineralogical compositions. 
The study well data is plotted on the same ternary diagram using the same three mineralogy logs and color coded by formation (Figure 16). The Marcellus shale plots mostly in the clay-rich siliceous mudstone and mixed mudstone regions.

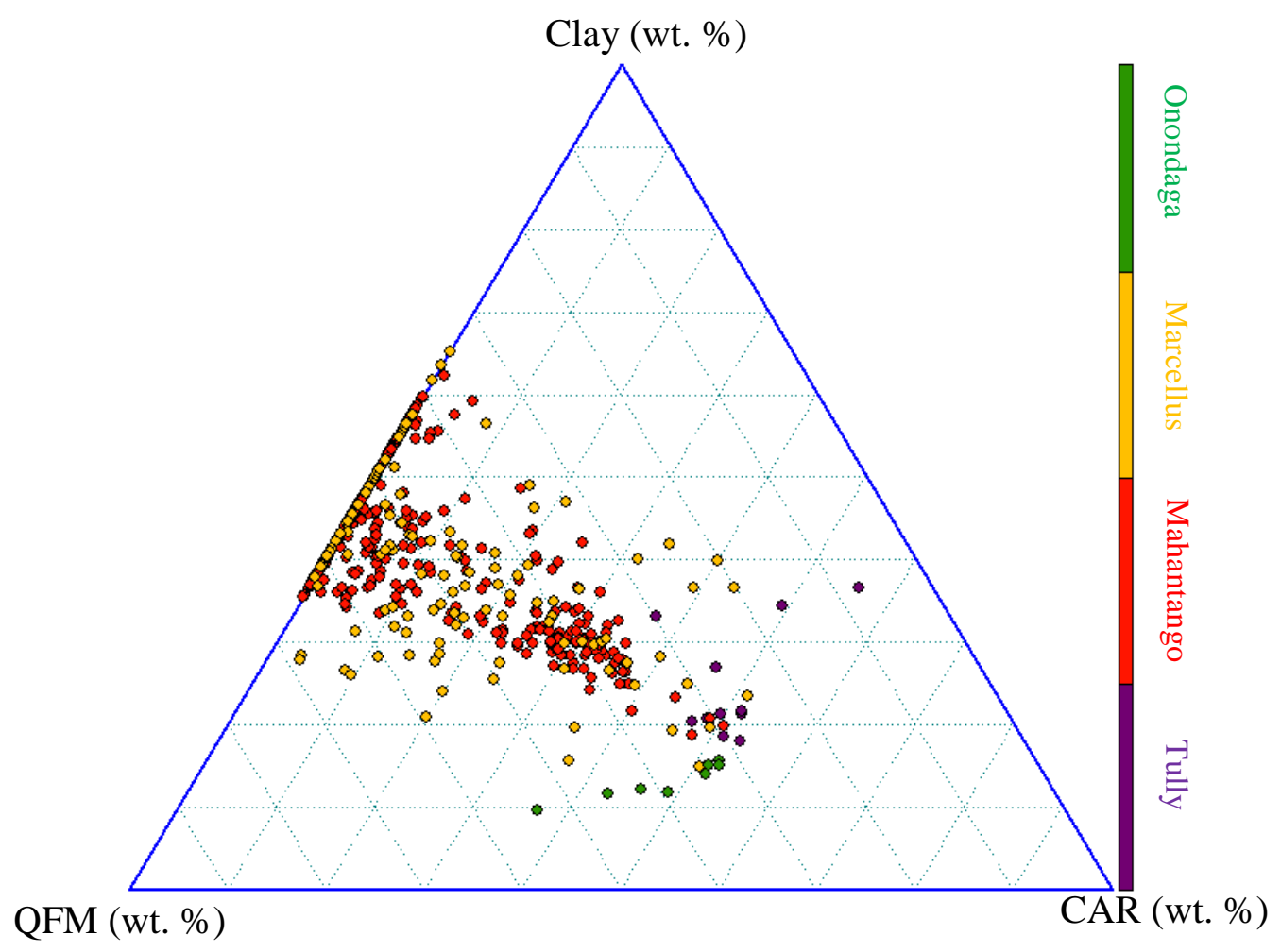

Figure 16: Four stratigraphic units in the study well plotted to assess mineralogy and rock type. 
The same points from all four formations are shaded by total organic content (TOC) to depict the intervals of organic richness (Figure 17). Almost all points in the Mahantango shale, Tully limestone and Onondaga limestone have less than 1\% TOC.

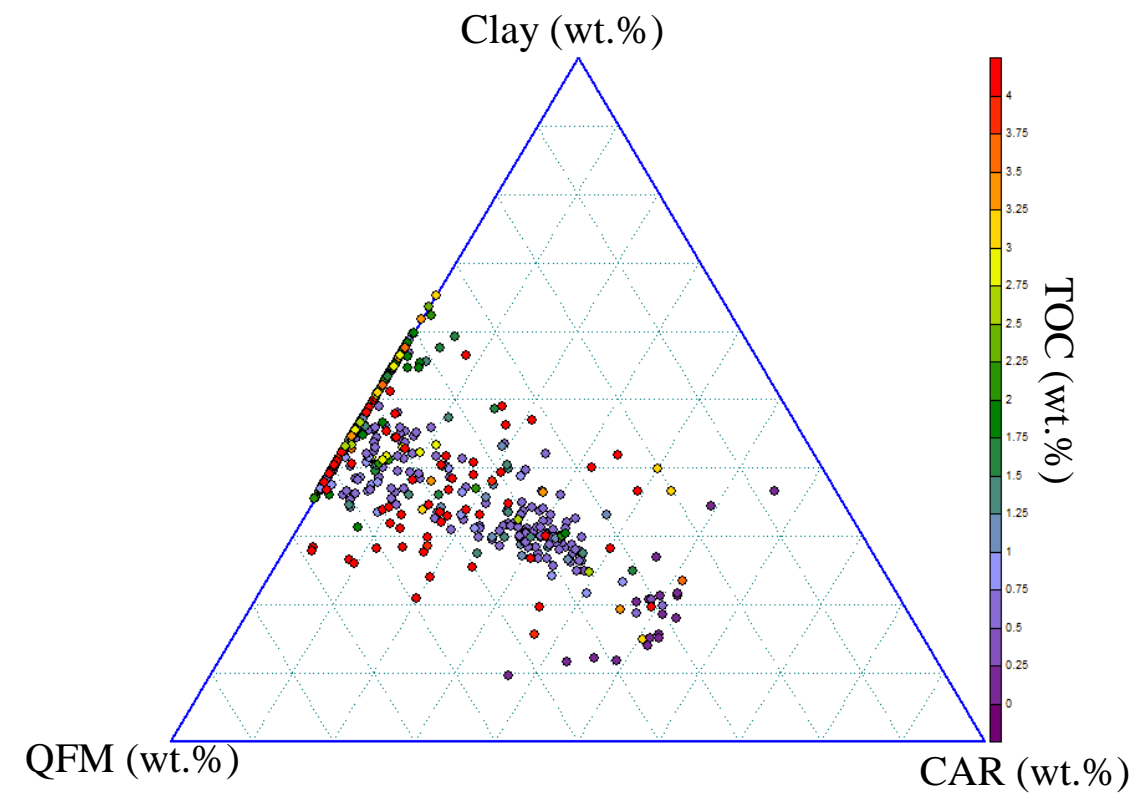

Figure 17: Four stratigraphic units in the study well shaded with total organic content.

Focusing solely on the Marcellus shale, the areas with clay-rich siliceous mudstone and mixed siliceous mudstone have the highest organic content above 4\% (Figure 18).

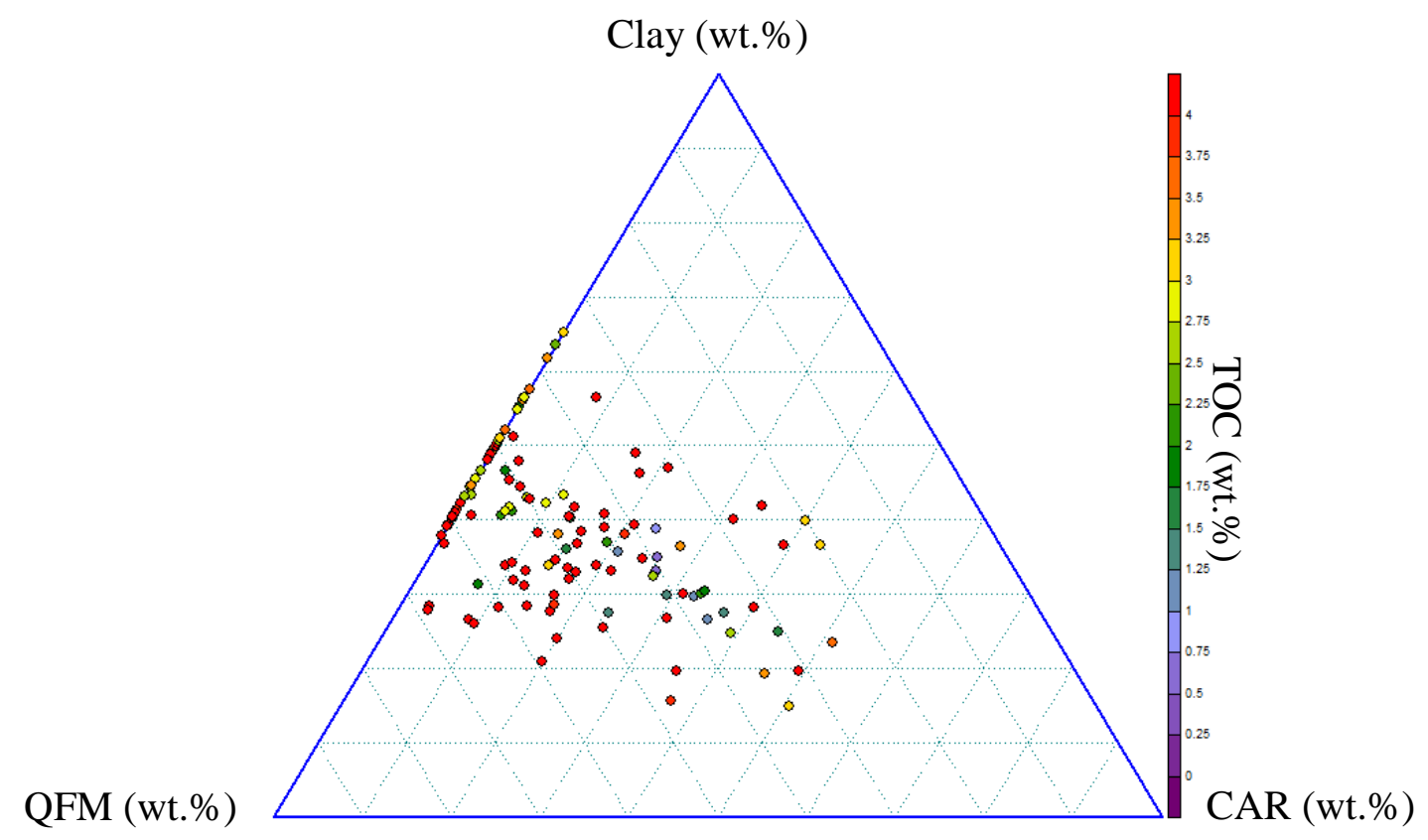

Figure 18: Marcellus shale shaded with total organic content. 
A secondary approach for mineral identification, if compositional logs are unavailable, are RHOmaa-Umaa crossplots (Doveton, 1994). A "RHOmaa - Umaa crossplot can be used effectively to gain more detailed insights into composition, particularly with regards to clay types" (Doveton, 1994). The gas effect in shales is easlity observed with a RHOmaa-Umaa crossplot (Doveton, 1994). RHOmaa is the apparent matrix density:

$$
\text { RHOmaa }=\frac{\text { RHOB }- \text { PHIA }}{1-\text { PHIA }}
$$

where RHOB is the bulk density and PHIA is the average porosity. Umaa is the volumetric photoelectric absorption coefficient of the matrix:

$$
\mathrm{Umaa}=\frac{\mathrm{U}-\mathrm{PHIA}}{1-\mathrm{PHIA}}
$$

where $\mathrm{U}$ is the volumetric photoelectric absorption index and PHIA is the average porosity. The volumetric photoelectric absorption index is:

$$
\mathrm{U}=\mathrm{Pe} * \rho \mathrm{b}
$$

where $\mathrm{Pe}$ is the photoelectric factor and $\rho \mathrm{b}$ is the bulk density (Doveton, 1994).

A RHOmaa-Umaa crossplot depicts the mineralogy of the entire well in reference to common minerals (Figure 19). The Marcellus shale interval plots near the clay minerals in the gas effect region (Figure 20). 


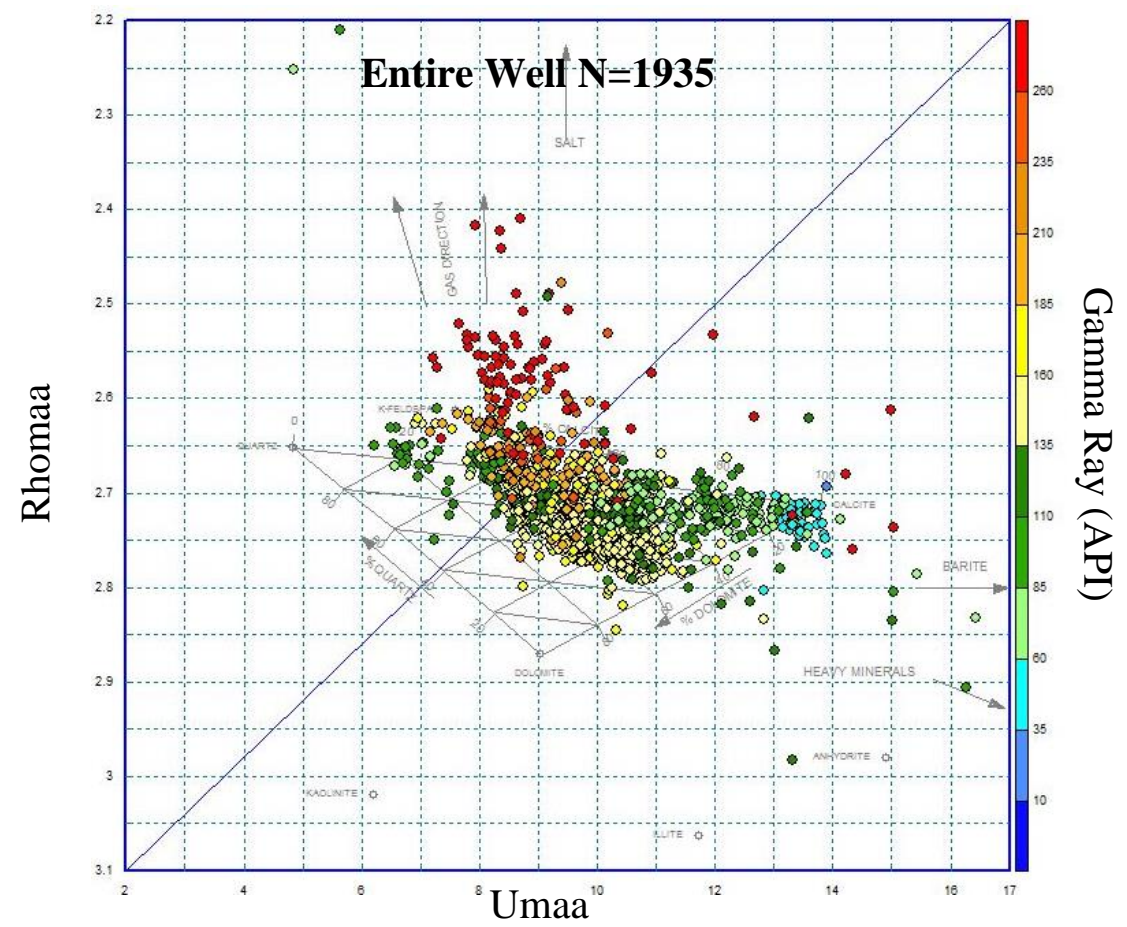

Figure 19: RHOmaa Umaa cross plot with depth interval for the entire well.

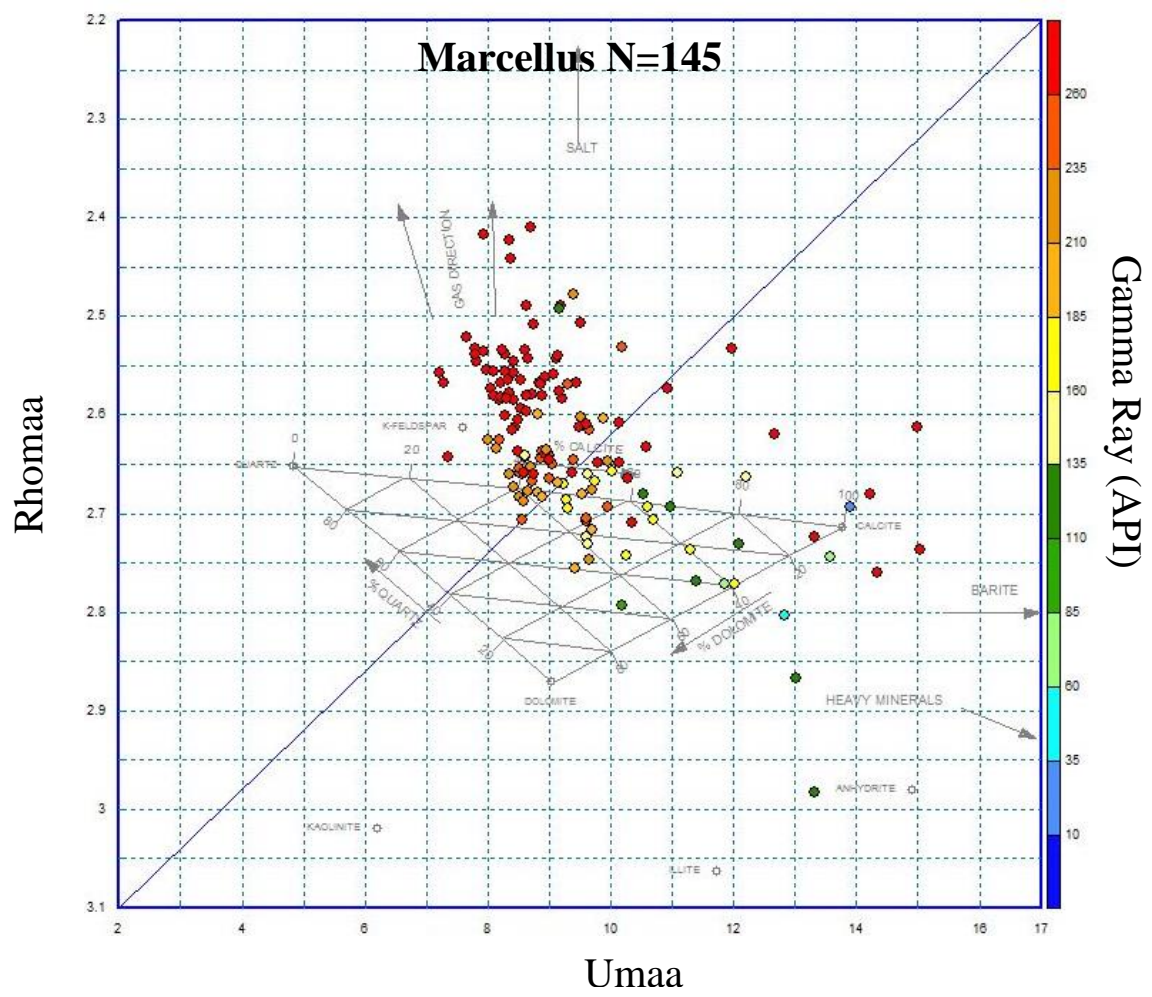

Figure 20: Depth interval from -7163 to -7235 feet measured depth to highlight the organic rich Marcellus shale plotting in the gas detection region. 


\subsubsection{Mechanical Stratigraphy}

Mechanical properties such as elastic moduli and brittleness provide insight into zones of weakness in a rock that may be more amenable to hydraulic stimulation treatment which aids in wellbore planning of unconventional reservoirs. Various studies have been completed to determine the mechanical properties of various shale formations for application in horizontal drilling (Grieser 2007, Wang, 2009, Alzate 2012, Alzate et al. 2012, Alzate and Devegowda 2013, Altamar and Marfurt 2014, Weicht 2015). These studies use vertical and horizontal well $\operatorname{logs}$, surface 3D seismic, microseismic and inverted seismic to calculate Poisson's ratio, Young's modulus, Lame's parameters and estimate brittleness.

When a rock is exposed to stress the rock begins to deform. With increasing stress the rock experiences different stages of deformation which are elastic, ductile, and fracture. Based on the deformation of the rock it is possible to classify the rock into either ductile or brittle behavior. A rock is ductile when it has a relatively small region of elastic behavior absorbing a lot of energy before failure. In contrast, a rock is brittle if the material under stress has a relatively larger region of elastic behavior and does not absorb much energy before failure (Altamar and Marfurt, 2014).

Brittleness is defined as the measurement of stored energy before failure and is a function of rock strength, lithology, texture, effective stress, temperature, fluid type, diagenesis and total organic content (Perez, 2013). Brittleness may be assessed through either mineralogy or elastic rock properties. The most widely used quantification for brittleness is the Brittleness Index (BI) (Perez, 2013). The Brittleness Index (BI) proposed by Jarvie et al. (2007) uses mineralogy to assess rock brittleness: 


$$
B I=\frac{Q z}{Q z+C a+C l y}
$$

where $\mathrm{Qz}$ is percentage of quartz, $\mathrm{Ca}$ is percentage of calcite and Cly is percentage of clay.

Another Brittleness Index that relies on knowledge of mineralogy and total organic content was proposed by Wang and Gale (2009):

$$
B I=\frac{Q z+D o l}{Q z+D o l+C a+C l y+T O C}
$$

where Qz is percentage of quartz, Dol is percentage of dolomite, Ca is percentage of calcite and Cly is percentage of clay, and TOC is total organic content.

The second way to quantify rock brittleness is through application of elastic property calculations. Two elastic moduli that serve this purpose are Young's modulus and Poisson's ratio. Young's modulus shows the relationship of longitudinal stress to strain:

$$
\mathrm{E}=\frac{\sigma}{\varepsilon}
$$

where $\sigma$ is the tensile stress and $\varepsilon$ is the extensional strain (Sheriff, 1997). Stress is force per unit area which is measured in newtons per square meter. Strain is a unit less proportional deformation. Therefore, Young's modulus is measured in the units of stress or Pascals. Poisson's ratio is the ratio of transverse to axial strain:

$$
v=\frac{\varepsilon \text { trans }}{\text { caxial }}
$$

where etrans is the transverse strain and eaxial is the axial strain (Sheriff, 1997). Transverse strain is negative for tension and positive for compression. Axial strain is positive for tension and negative for compression. Strain is measured as changes in length and Poisson's ratio is a unit less number. 
Poisson's ratio and Young's modulus may also be calculated using velocity and density geophysical logs (Sheriff, 1997). Poisson's ratio is calculated with velocity logs:

$$
v=\frac{[\mathrm{Vp} 2-2 \mathrm{Vs} 2]}{2(V p 2-V s 2)}
$$

where Vs is the shear velocity log and Vp is the compressional velocity log. Young's modulus is calculated with velocity and density logs:

$$
\mathrm{E}=\rho V s 2 \frac{[3 \mathrm{Vp} 2-2 \mathrm{Vs} 2]}{\left[V p 2-\frac{1}{3} V s 2\right]}
$$

where $\rho$ is the density, $\mathrm{Vs}$ is the shear velocity, and $\mathrm{Vp}$ is the compressional velocity.

After Poisson's ratio and Young's modulus are calculated, the brittleness parameter can be estimated. Three equations sum up the elastic properties to create a Brittleness Average (BA) proposed by Grieser and Bray (2007). First the average brittleness for Young's modulus is calculated:

$$
\text { Ebrittleness }=\frac{\mathrm{E}-\mathrm{Emin}}{\mathrm{Emax}-\mathrm{Emin}}
$$

where E is Young's modulus, Emin is the minimum Young's modulus and Emax is the maximum Young's modulus. Next the average brittleness for Poisson's ratio is calculated:

$$
\text { vbrittleness }=\frac{v-v \max }{v \min -v \max }
$$

where $v$ is Poisson's ratio, vmin is the minimum Poisson's ratio and vmax is the maximum Poisson's ratio. Finally the Brittleness Average may be calculated:

$$
\mathrm{BA}=\frac{\text { Ybrittleness }+ \text { vbrittleness }}{2}
$$


Brittleness Index and Brittleness Average were calculated for the Goff \#55 well. Based on a previous study of this well (Hilliard, 2015), Brittleness Index method was more accurate than the Brittleness Average method for limestone intervals. For this reason the Brittleness Index method is used as the primary brittleness estimator at this well.

Plotting the Brittleness Index against gamma ray, similar to Perez and Marfurt (2013), reveals zones of ductility and brittleness (Figure 21). The Tully limestone plots in the ductile region, the Onondaga limestone plots in the less brittle to less ductile region and the Mahantango and Marcellus shale formations plot in the brittle to less brittle region.

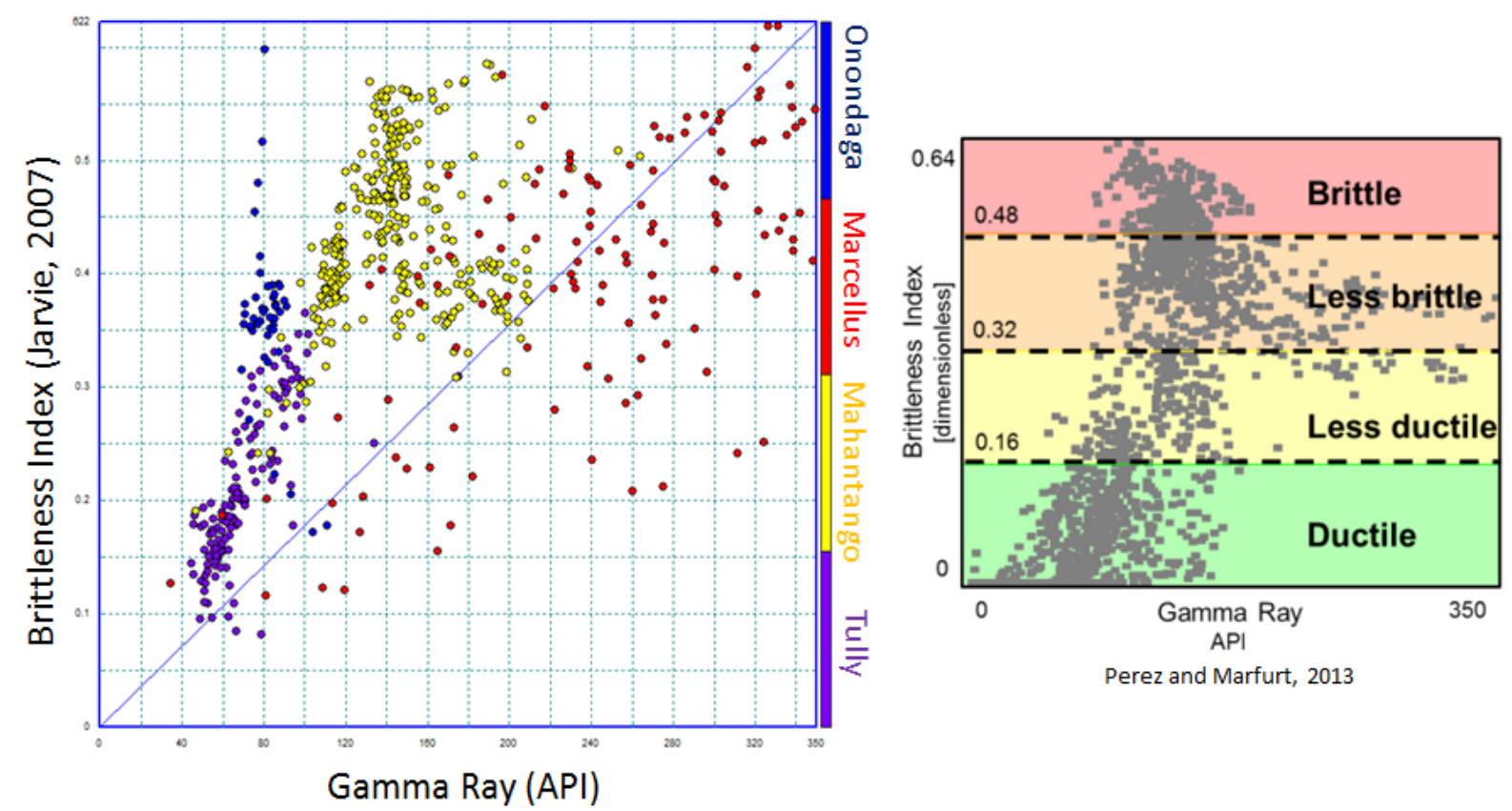

Figure 21: Brittleness Index and gamma ray cross plot color coded by formation. Ductile and brittle constraints by Perez and Marfurt (2013).

Using the same cross plot and shading by total organic content shows that there is a zone in the Marcellus shale that is both brittle and TOC rich (Figure 22). 

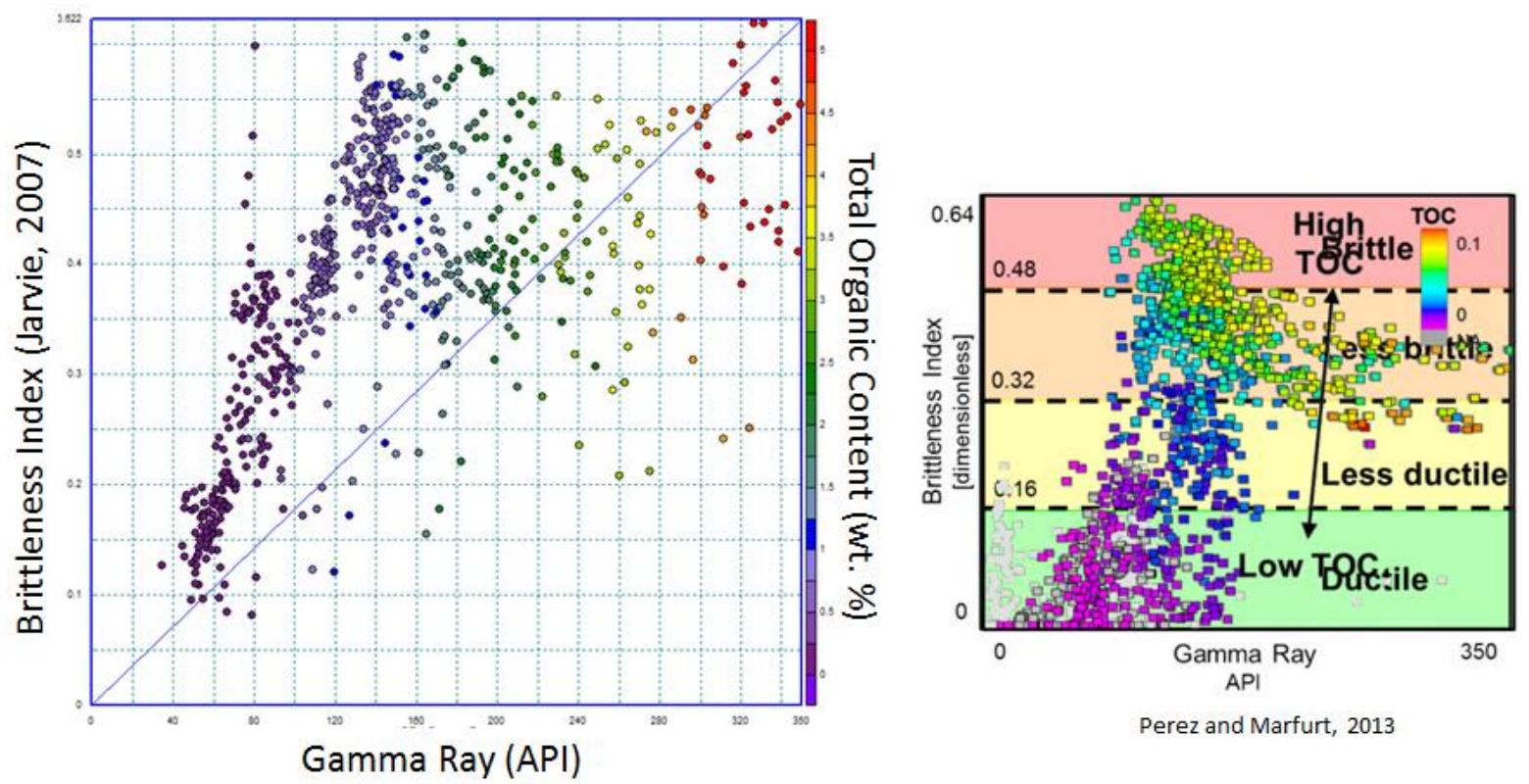

Figure 22: Brittleness Index and gamma ray cross plot shaded by TOC. Ductile and brittle constraints with TOC by Perez and Marfurt (2013).

Other than Young's modulus and Poisson's ratio the Lame parameters are also used to calculate rock brittleness. Lame parameters relate to the components of stress and strain. The Lame parameters are denoted by $\lambda$ and $\mu$ and are referred to as Lame's first parameter and Lame's second parameter respectively. Lame's first parameter is used to assess incompressibility of rock and it is related to bulk modulus. Lame's first parameters may be expressed in terms of compression and shear wave velocities or in terms of Young's modulus and Poisson's ratio (Mavko et al., 2013):

$$
\begin{aligned}
& \lambda=\rho\left(\mathrm{Vp}^{2}-2 \mathrm{Vs}^{2}\right) \\
& \lambda=\frac{\mathrm{E} v}{(1+v)(1-2 v)}
\end{aligned}
$$

where $\lambda$ is Lame's first parameter, $\rho$ is density, Vs is the shear velocity log, $\mathrm{Vp}$ is the compressional velocity log, E is Young's modulus and $v$ is Poisson's ratio. Lame's second 
parameter is equal to the shear modulus $\mu$ which corresponds to the rigidity of a material. Lame's second parameter may be expressed in terms of compression and shear wave velocities or in terms of Young's modulus and Poisson's ratio (Mavko et al., 2013):

$$
\begin{aligned}
& \mu=\rho\left(\mathrm{Vs}^{2}\right) \\
& \mu=\frac{E}{2(1+v)}
\end{aligned}
$$

where $v$ is Lame's second parameter, $\rho$ is density, Vs is the shear velocity, E is Young's modulus and $v$ is Poisson's ratio.

Combining Lame's first and second parameters with density yields the lambda-rho $(\lambda \rho)$ and mu-rho $(\mu \rho)$ equations:

$$
\begin{gathered}
\lambda \rho=\rho^{2}\left(V p^{2}-2 V s^{2}\right) \\
\mu \rho=\rho^{2}\left(V s^{2}\right)
\end{gathered}
$$

where $\lambda$ is Lame's first parameter, $v$ is Lame's second parameter, $\rho$ is density, Vs is the shear velocity and $\mathrm{Vp}$ is the compressional velocity.

Lambda-rho and mu-rho analyses may be useful to classify different zones of unconventional shale reservoirs (Alzate 2012; Alzate et al., 2012; Weicht 2015). The four zones distinguished with lambda-rho mu-rho cross plots are 1. Brittle and TOC rich, 2. Brittle and TOC poor, 3. Ductile and TOC rich and 4. Ductile and TOC poor. In an unconventional shale reservoir, the most favorable zone for effective hydraulic stimulation and hydrocarbon production is the zone that is both brittle and TOC rich. This zone would respond best to hydraulic fracture treatment and have the highest potential for successful hydrocarbon extraction. The higher silica content is responsible for the more brittle response. The silica makes the rock 
easier to fracture opposed to a higher clay content which would absorb more energy. The higher TOC is important because this area is most rich in hydrocarbon. Therefore, with a greater ability to fracture which creates more fluid migration pathways and the higher hydrocarbon content, these areas presumably offer the best targets for unconventional drilling.

To assess the vertical variability of these parameters within the Marcellus shale mechanical properties are plotted for the Goff well (Figure 23). The variation along depth may provide insight into the best location to land a lateral well. The depth interval shown is from the top pick of the Marcellus shale from Hilliard (2015) to the top of the Onondaga limestone. Track 1 is gamma ray for a reference log and track 2 shows TOC shaded in red where it is greater than $4 \mathrm{wt} . \%$. The brittleness index and corresponding compositional mineralogical logs are plotted in track 3 and 4 respectively. Track 5 shows density below $2.55 \mathrm{~g} / \mathrm{cc}$ shaded in green. This is to highlight areas of potentially higher kerogen content because kerogen has a low density and will bring the bulk density down. Sonic travel time is also plotted in track 5 . Track 6 shows the Young's modulus and Poisson's ratio calculations with shading of the cutoff limits for the cut off limits developed in this study (Table 2). Track 7 depicts the lame parameter calculations. A twenty-three foot interval in the lower Marcellus shale has the highest average TOC and highest average brittleness index. This interval is from 7208-7231. This zone has higher silica content, shown by the sand colored mineralogical log and a lower bulk density. The mechanical properties all correspond to a zone of increased brittleness. 


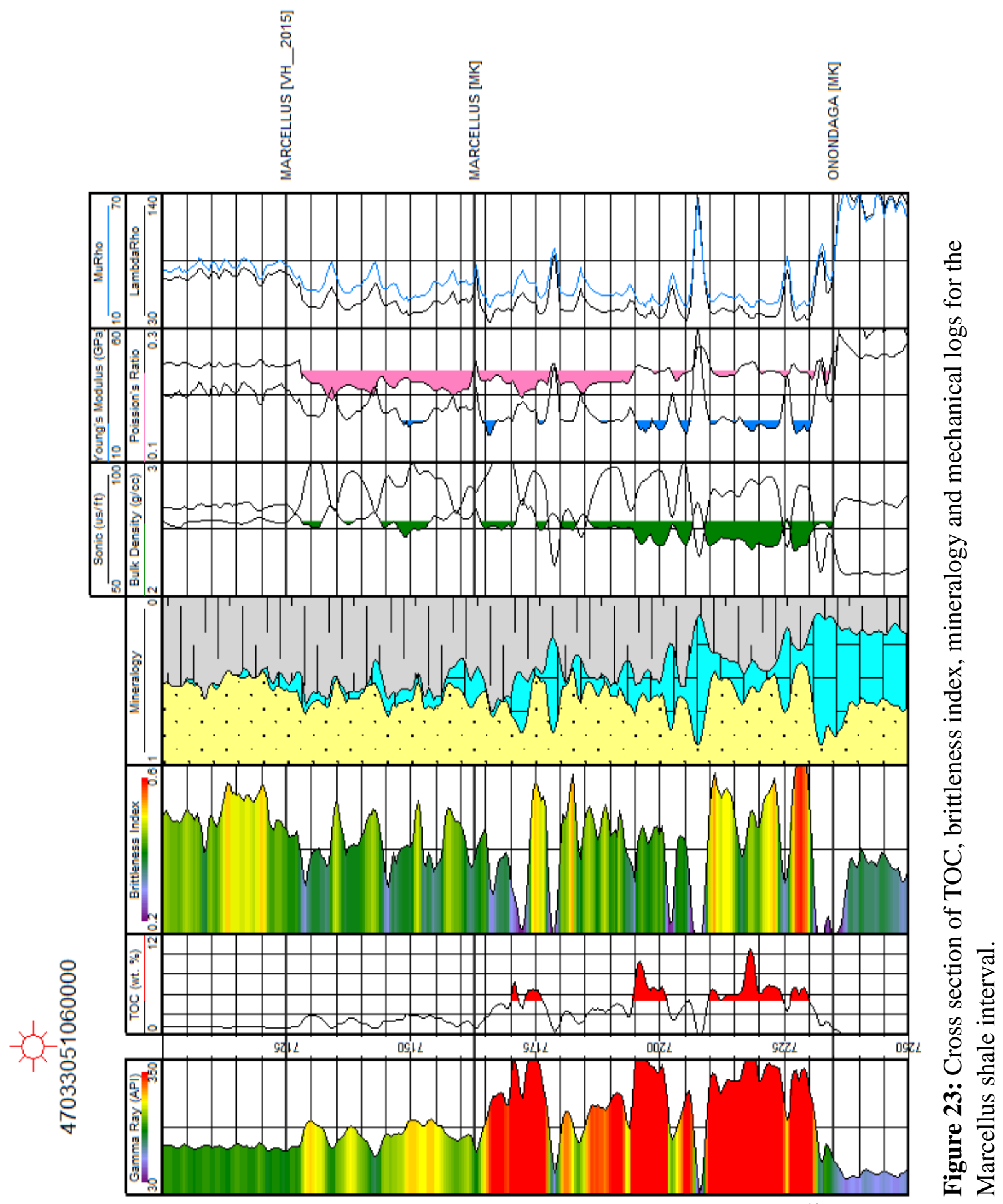

Lower Marcellus

7208'----7231' 
Lambda-rho and mu-rho cross plots were generated for the Goff \#55 well from the top of the Tully Limestone to the top of the Huntersville chert (Figure 24). The Onondaga and Tully limestone formations have higher values of lambda-rho and mu-rho. The Mahantango and Marcellus shale formations have lower values of lambda-rho and mu-rho.

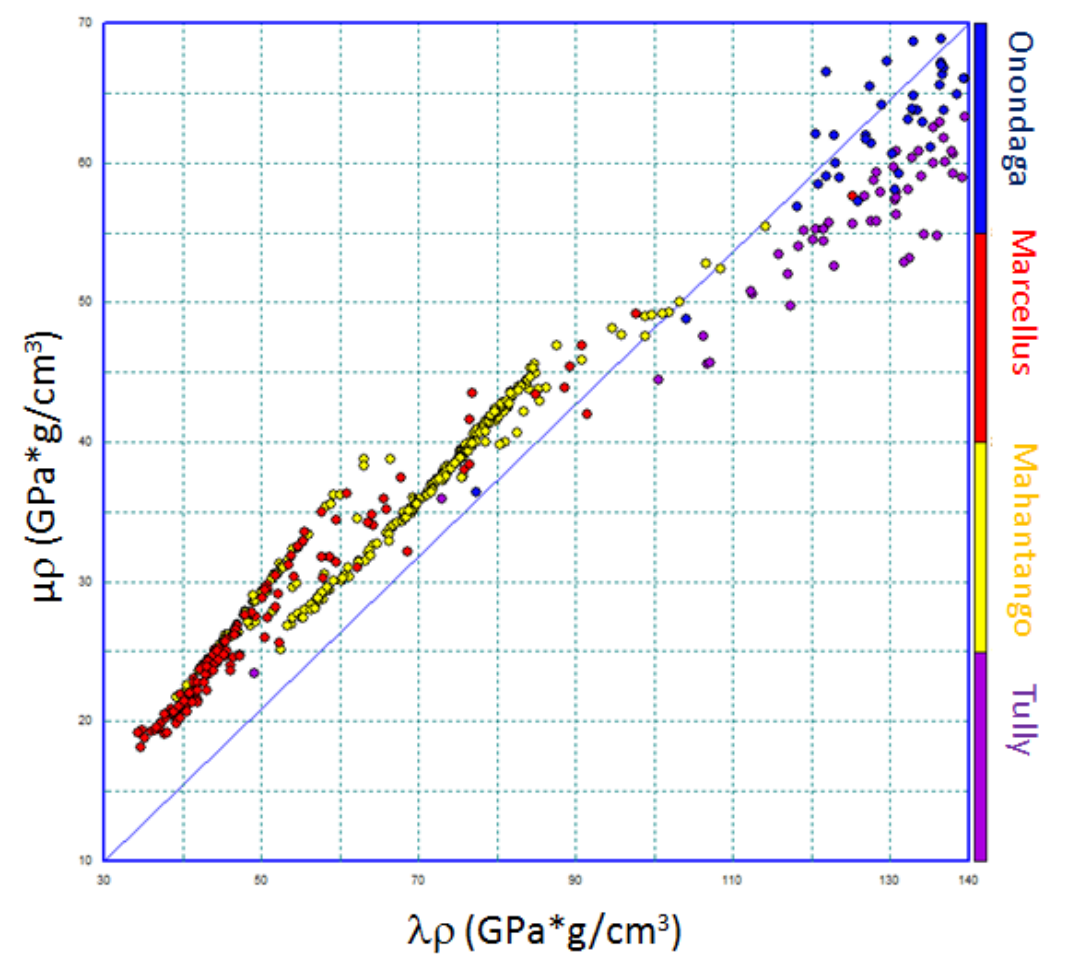

Figure 24: Lambda-rho and Mu-rho cross plot from the study well in Harrison County color coded by formation.

When plotted with total organic content and brittleness index the lambda-rho mu-rho cross plots confirm Alzate et al.'s 2012 conclusion that lambda-rho mu-rho cross plots provide insight into areas of high brittleness and organic richness. Total organic content increases when lambda-rho and mu-rho decrease (Figure 25). The portion of the Marcellus shale that has the highest organic content also has the lowest lambda-rho and mu-rho values. Brittleness Index increases when lambda-rho and mu-rho decreases (Figure 26). There is a trend in each shale 
interval with a high Brittleness Index at the end of the formation that is closest to the lower end of each formation's lambda-rho and mu-rho values respectively (Figure 26).

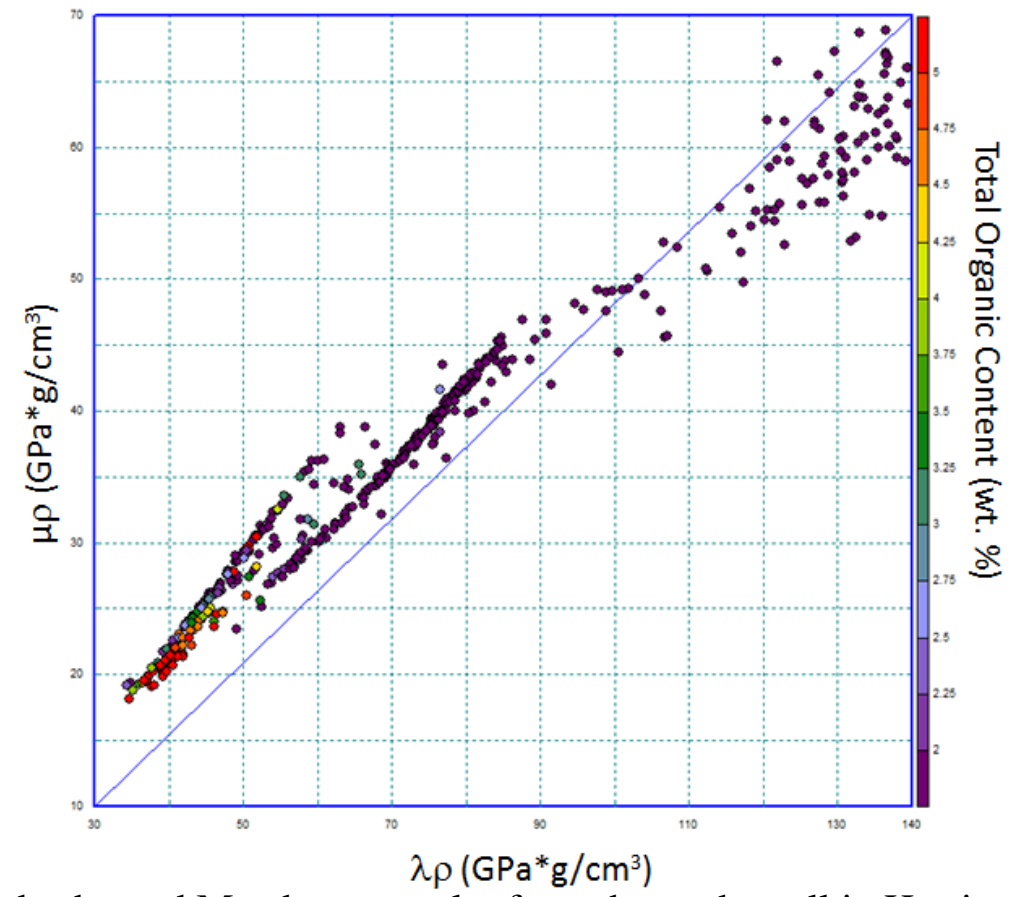

Figure 25: Lambda-rho and Mu-rho cross plot from the study well in Harrison County color coded by total organic content.

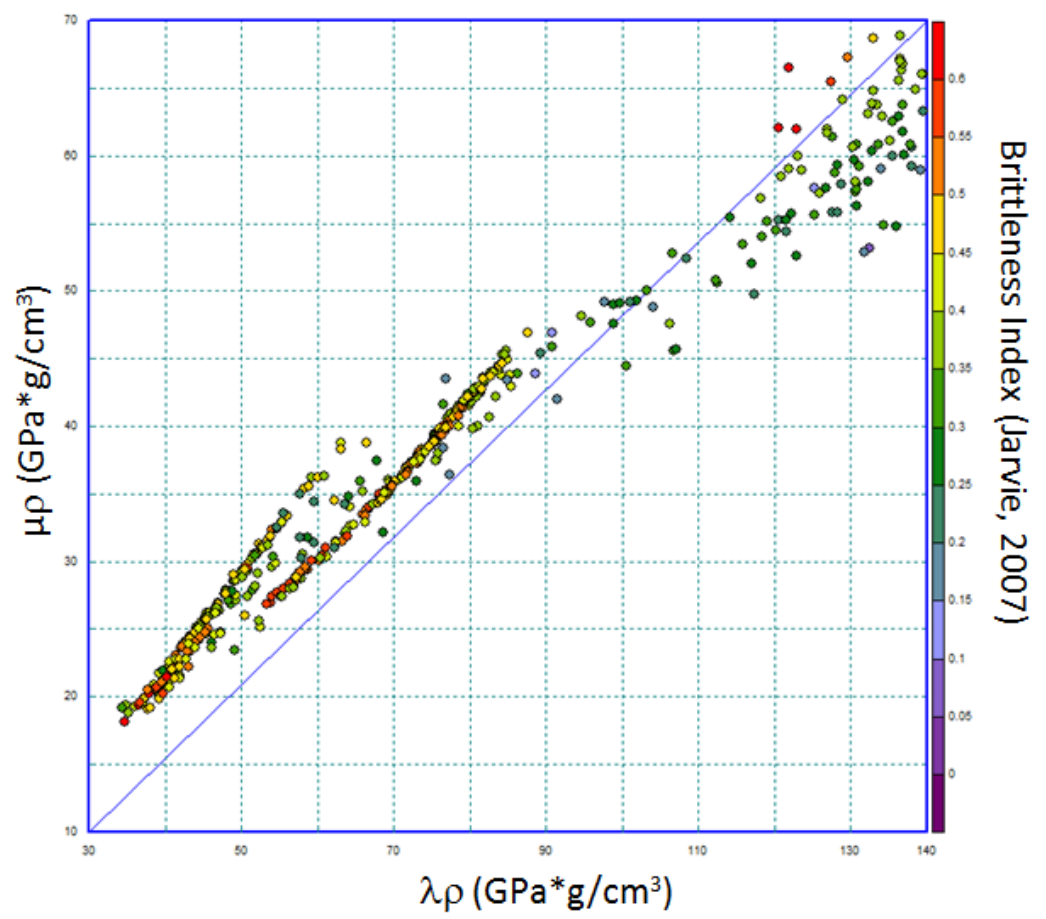

Figure 26: Lambda-rho and Mu-rho cross plot from the study well in Harrison County color coded by Brittleness Index. 
The areas of low lambda-rho and mu-rho that are indicative of high brittleness and high organic content are constrained by Young's modulus and Poisson's ratio (Alzate, 2012; Weicht, 2015; Wilson, 2015). The Poisson's ratio and Young's modulus cut off values for lambda-rho mu-rho cross plots was developed and applied to the Barnett shale by Alzate (2012) (Figure 27). The zone most preferable for hydraulic treatment was the zone with the lowest lambda-rho and mu-rho values which is also the zone of highest brittleness and most organic richness. The Young's modulus ranges for this zone are 23-37.5 GPa and the Poisson's ratio range is from $0.15-0.23$.

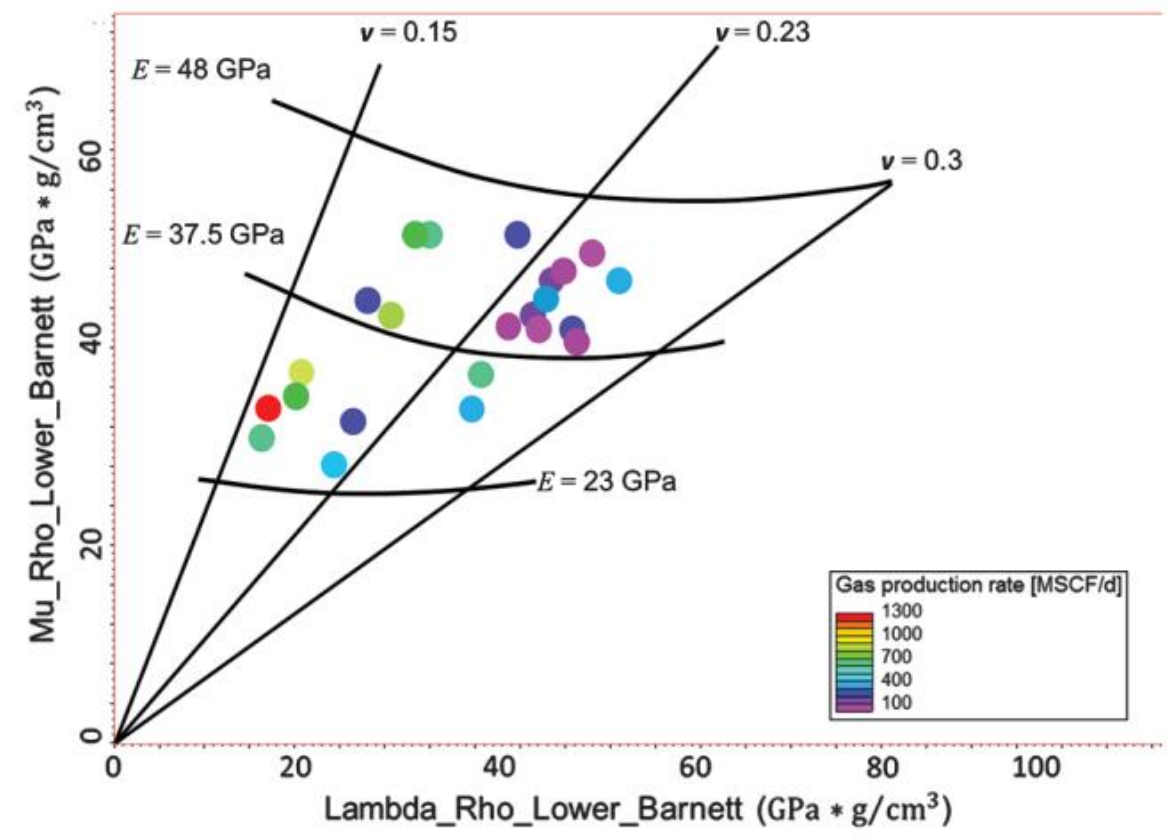

Figure 27: Lambda-rho and Mu-rho cross plot with Poisson's ratio and Young's modulus cut off parameters for the Barnett shale study (Alzate, 2012).

The Poisson's ratio and Young's modulus cut off parameters for the lambda-rho mu-rho cross plot for this study were based on shading the lambda-rho versus mu-rho cross plot by total organic content and Brittleness Index to find the zone with the highest brittleness and most organics (Figures 25 and 26). The Poisson's ratio and Young's modulus cut off parameters for 
the Marcellus shale study well in Harrison County West Virginia are 20-25 GPa and 0.2-0.25 respectively (Figure 28).

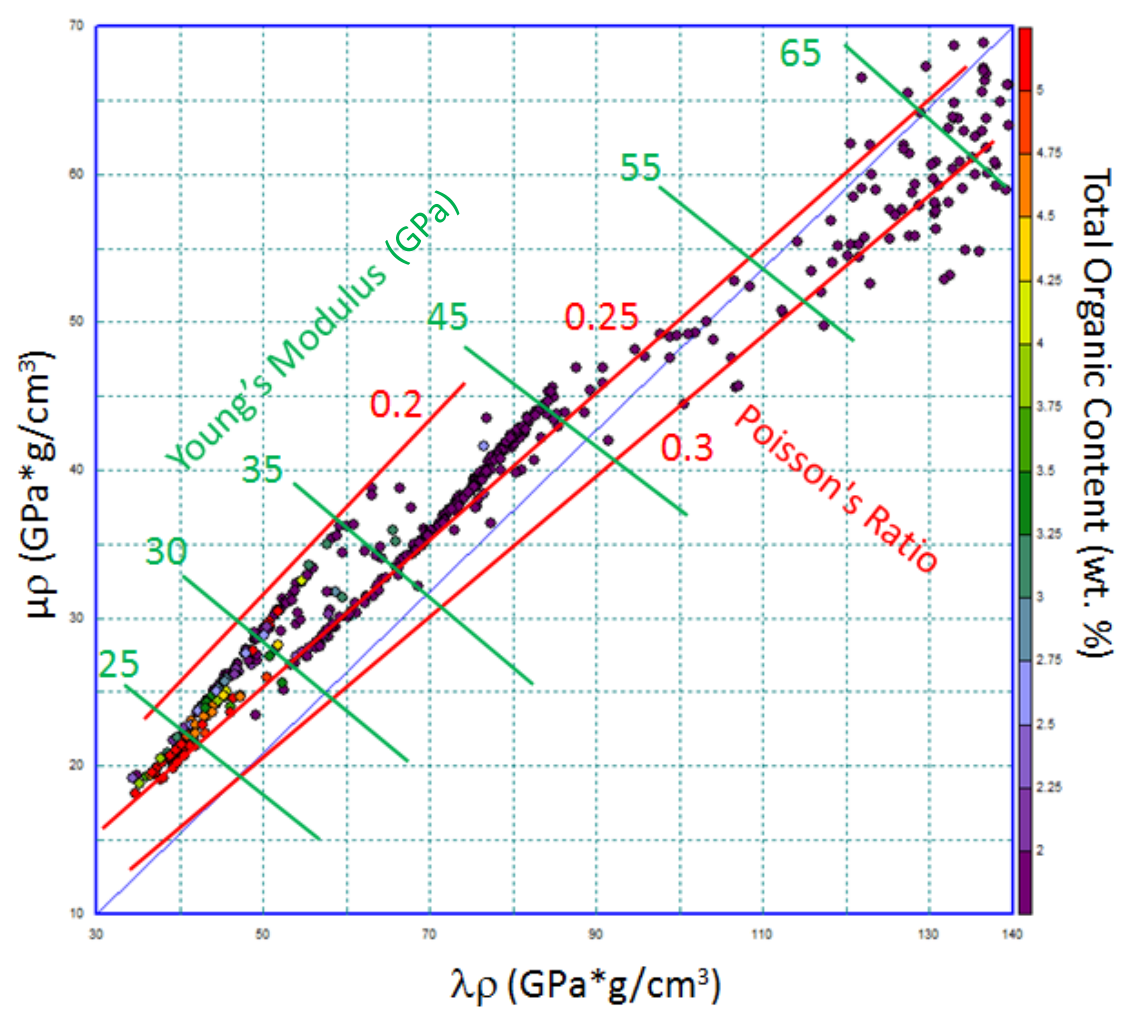

Figure 28: Lambda-rho and Mu-rho cross plot with Poisson's ratio and Young's modulus cut off parameters for the Harrison County Marcellus shale study.

Weicht (2015) showed that Poisson's ratio and Young's modulus cut off parameters change for two Marcellus shale wells in close proximity to each other. The cut off parameters for these two wells are summarized in Table 2. However, these cut offs were determined based on the current "producing intervals" from the two wells and not by picking areas of high TOC and high brittleness in the cross plots (Weight, 2015, p.46). The Young's modulus and Poisson's ratio cut off parameters for the Marcellus shale study wells in Taylor County West Virginia are 19.2-26.3 GPa and 0.10-0.27 respectively. 
Wilson (2015, unpublished class lecture) also used Poisson's ratio and Young's modulus cut off parameters and looked at distribution of gamma ray for a Marcellus shale well in Monongalia County West Virginia (Figure 29).

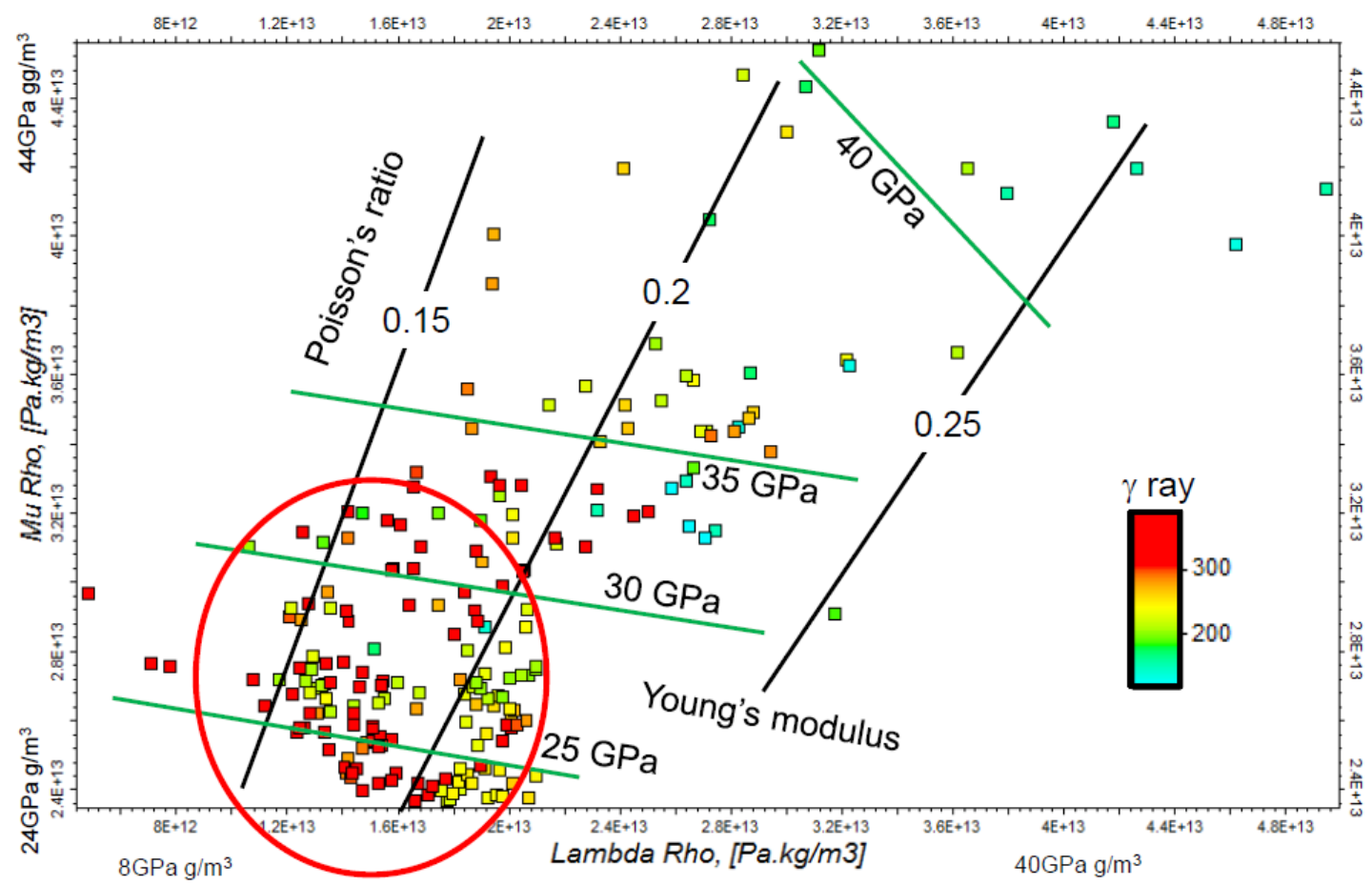

Figure 29: Lambda-rho and Mu-rho cross plot with Poisson's ratio and Young's modulus cut off parameters for the Monongalia County Marcellus shale (Wilson, 2015 unpublished class lecture).

Poisson's ratio and Young's modulus cut off parameters change remarkably from each well location and between shale plays (Table 2). However, the cross plots of brittleness and organic content from this study (Figures 25 and 26) confirm Alzate's (2012) statement that the lowest lambda-rho and mu-rho areas are indicative of the most brittle and highest total organic content regions. 


\begin{tabular}{|l|l|l|l|l|}
\hline Author & Year & Shale & $\begin{array}{l}\text { Poisson's } \\
\text { Ratio Range }\end{array}$ & $\begin{array}{l}\text { Young's } \\
\text { Modulus } \\
\text { Range (GPa) }\end{array}$ \\
\hline Alzate & 2012 & Barnett & $0.15-0.23$ & $23.0-37.5$ \\
\hline Weicht, 1 & 2015 & Marcellus & $0.21-0.27$ & $19.0-26.3$ \\
\hline Weicht, 2 & 2015 & Marcellus & $0.10-0.16$ & $21.2-25.7$ \\
\hline Wilson & 2015 & Marcellus & $\sim 0.15-0.20$ & $\sim 25.0-30.0$ \\
\hline Kish & 2015 & Marcellus & $0.20-0.24$ & $20.0-25.0$ \\
\hline
\end{tabular}

Table 2: Poisson's ratio and Young's modulus ranges for the multiple lambda-rho mu-rho studies (Alzate 2012, Weicht 2015, Wilson 2015 unpublished).

Young's modulus and Poisson's ratio were observed at four Marcellus shale well sites in West Virginia: one in Harrison County, one in Monongalia County, and two in Taylor County. The Marcellus shale exhibits mechanical rock property variability between the four well sites. Although Poisson's ratio and Young's modulus cut off ranges vary, the lambda-rho mu-rho cross plots are still effective at identifying the most brittle and organic rich zones.

In summary, brittleness estimations and mineralogy are needed for the design of hydraulic fracture stimulation treatment, specifically for fluid selection (Rickman et al., 2008). Brittleness and mineralogy in shale reservoirs relate to microseismic event distribution and gas production (Perez and Marfurt, 2013; Alzate and Devegowda, 2013) making these types of assessments important for unconventional gas development. Future suggestions for brittleness assessments are provided in Chapter 8: Future Work. 


\section{SEISMIC WELL TIE AND RESOLUTION}

\subsection{Synthetic Seismogram}

A synthetic seismogram was created to correlate the Goff 55 well API: 47033051060000 and Goff 3D seismic data. A wavelet was extracted from the Goff 3D post stack migration data to create the synthetic seismogram. The wavelet was extracted from 50 traces near the Goff 55 well. Traces were extracted over a vertical seismic display section beginning at 0.755 milliseconds and ending at 1.525 milliseconds, which is centered around the Marcellus shale reflection event. The extracted wavelet is shown in Figure 30A. The subsequent tuning analysis chart provides the peak tuning time to be 0.011 seconds (Figure 30B).

The synthetic seismogram was created through the convolution of this extracted wavelet and the reflection coefficient series. The reflection coefficient or reflectivity $(\mathrm{R})$ is a function of acoustic impedance contrast (AI) which in turn relies on density $(\rho)$ and velocity (V).

$$
\begin{gathered}
\mathrm{AI}=\rho \mathrm{V} \\
\mathrm{R}=\left(\mathrm{AI}_{2}-\mathrm{AI}_{1}\right) /\left(\mathrm{AI}_{2}+\mathrm{AI}_{1}\right)
\end{gathered}
$$

The process is graphically displayed in Figure 31 . The density and sonic logs are multiplied to create acoustic impedance which is used to calculate the reflection coefficients. Gamma ray is shown as a reference log. The resulting synthetic seismogram is displayed with neighboring seismic traces. Middle Devonian stratigraphy are labeled in the zoomed in view of the synthetic (Figure 32). The tops of the Tully limestone, Mahantango shale, Marcellus shale and Onondaga limestone each have a distinct seismic response (Figure 32). The lower Marcellus shale does not have a resolvable seismic response (Figure 32). 


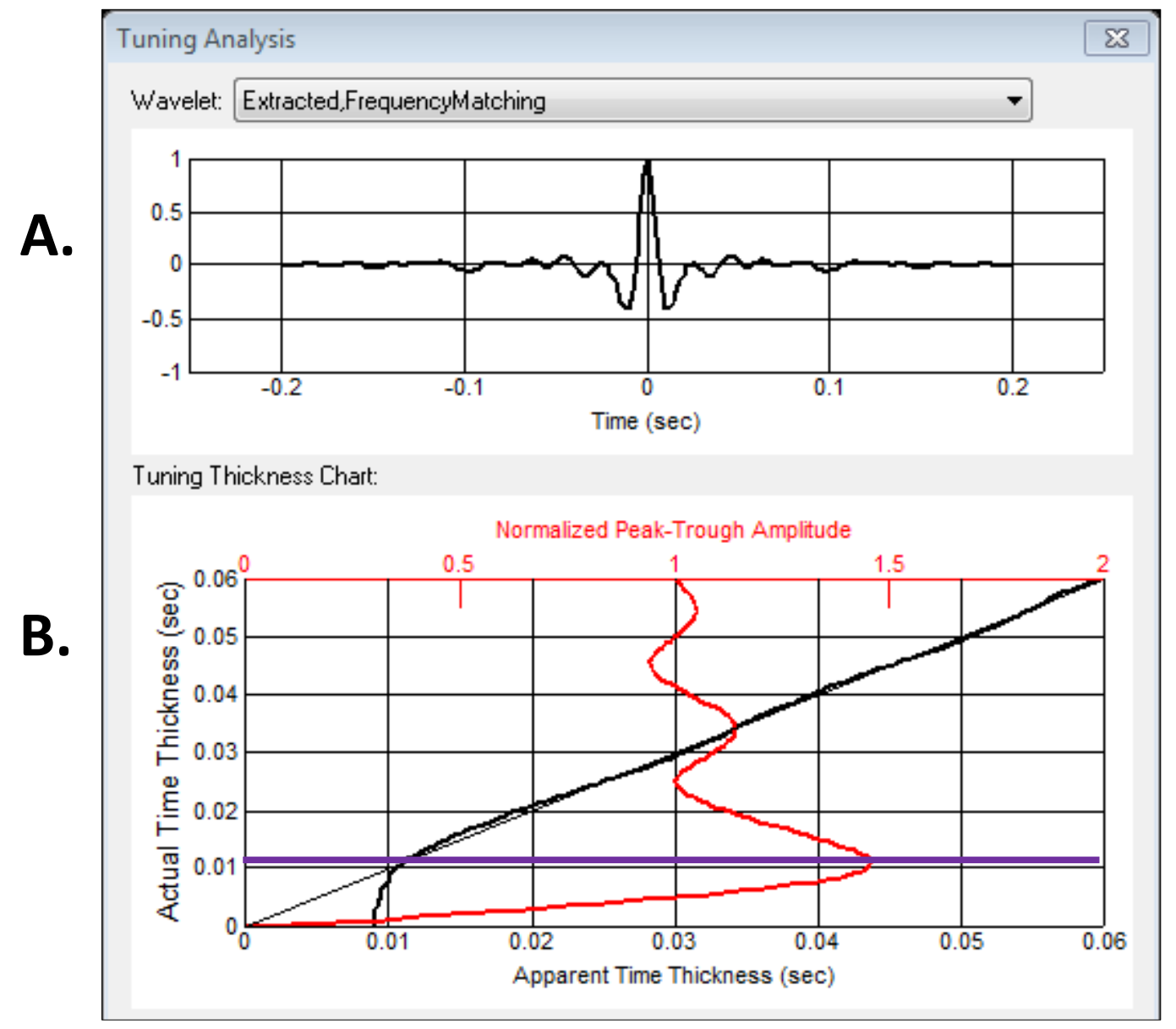

Figure 30: A: Goff 3D seismic extracted wavelet used for synthetic seismogram creation. B: Tuning thickness chart for this extracted wavelet, the peak of the tuning curve rests at 0.011 seconds marked by a purple line. 


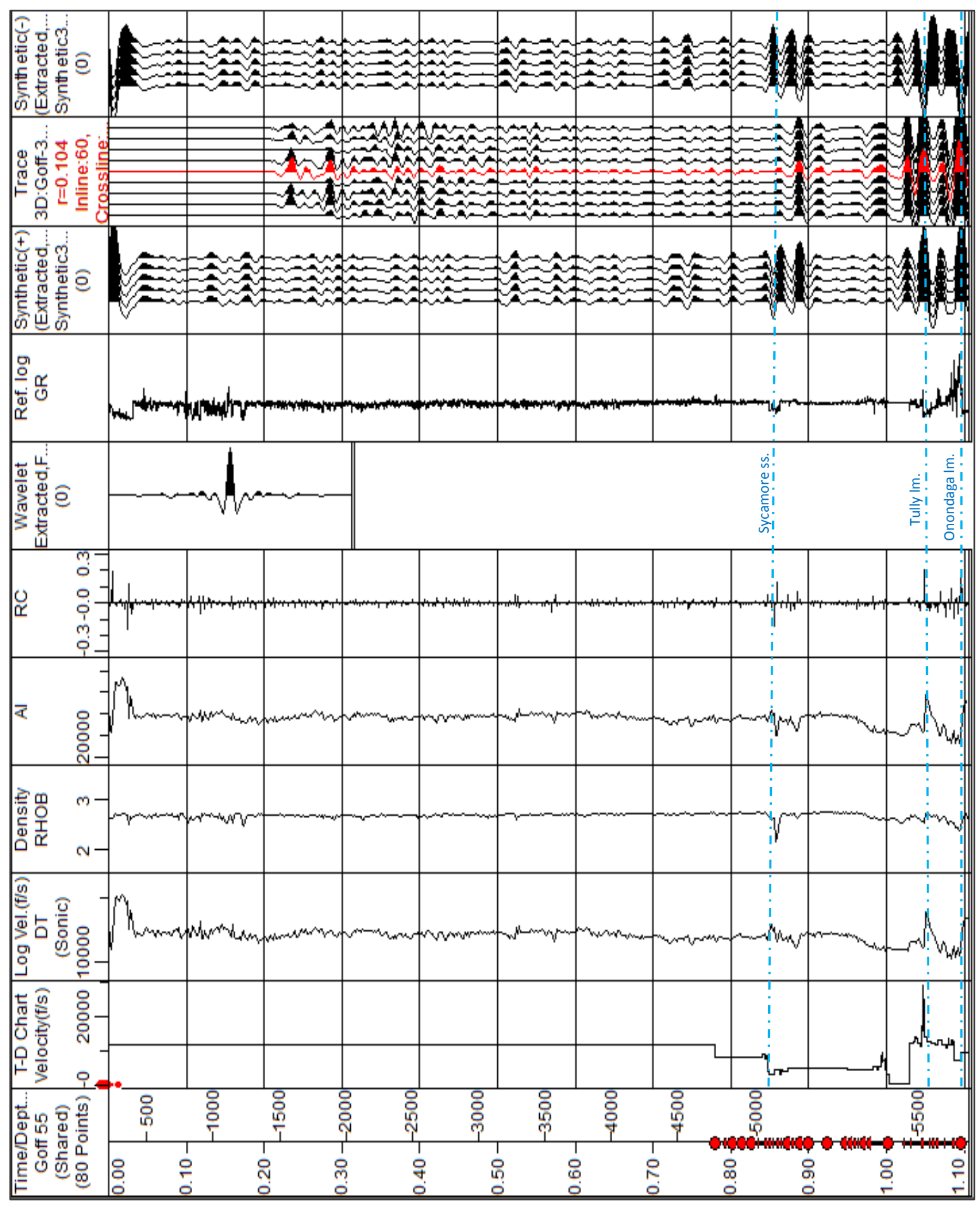

Figure 31: Logs and wavelet used in the creation of the synthetic seismogram at the Goff 55 well with neighboring seismic traces. The Tully and Onondaga limestone reflection events are labeled to highlight the Middle Devonian stratigraphy and overlying Sycamore sandstone for stratigraphic reference. 


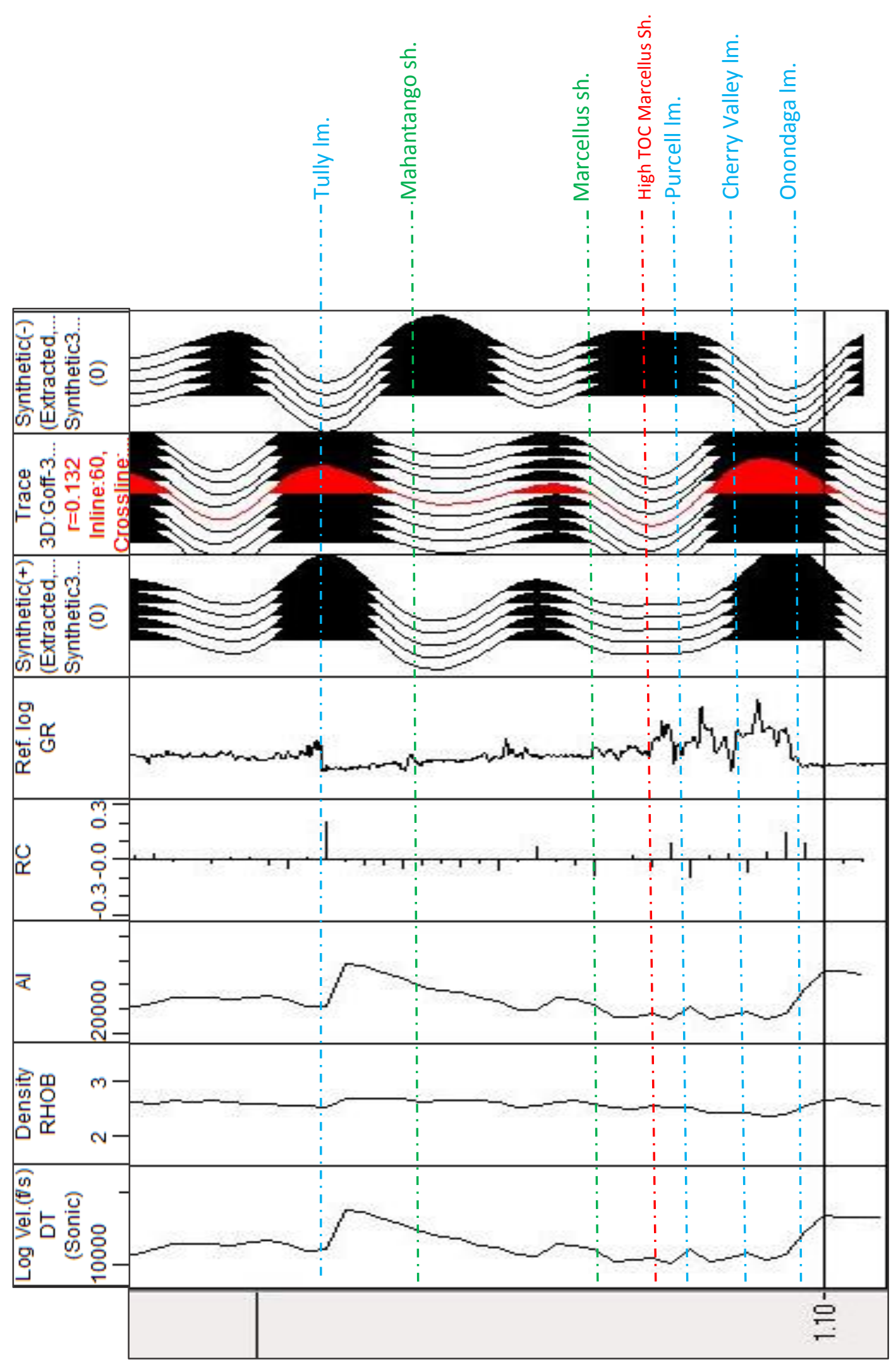

Figure 32: Zoomed in view of the synthetic seismogram with labeled Middle Devonian stratigraphy. 


\subsection{Horizon Picking}

Based on density and velocity well log information the Middle Devonian stratigraphy have the following reflectivity: Tully limestone-strong positive, Mahantango shale-strong negative, Marcellus shale-weak negative, Onondaga limestone-strong positive (Figure 32). The synthetic well tie confirms the amplitude and reflectivity of these reflections. The seismic response for these reflections is described as normal polarity which is represented with positive reflectivity as red and negative reflectivity as blue.

The top of the Marcellus shale is measured at -7129 feet measured depth and corresponds to a weak negative reflection event at -1.1 seconds two way travel time in the Goff $3 \mathrm{D}$ seismic dataset. The Onondaga limestone around -7235 feet measured depth which corresponds to a two way travel time of about -1.2 seconds and is a strong positive reflection event in the seismic.

The Gepco 3D seismic dataset does not contain a well with geophysical log information to construct a synthetic seismogram. The horizon picks for the Gepco 3D were therefore made by correlating the seismic reflections from the Goff 3D over to the Gepco 3D.

Reflections deeper than the Middle Devonian do not have well log control for the Goff 3D or the Gepco 3D at this site. Wells deeper than the Marcellus shale are rare in West Virginia and only recently being more extensively explored for potential gas production from Ordovician stratigraphy (Ross, 2015 and Shelor, 2015). For this reason, deeper reflections were picked based on the Kulander and Ryder (2005) regional seismic analysis which created a synthetic seismogram at the Burley No. 1 well located in southeastern Marshall County West Virginia (Figure 33). The 2D seismic line profile A-A' was also used in this study to correlate deeper 
reflection events near the 3D seismic surveys in Harrison County West Virginia (Figure 33 and $34)$.

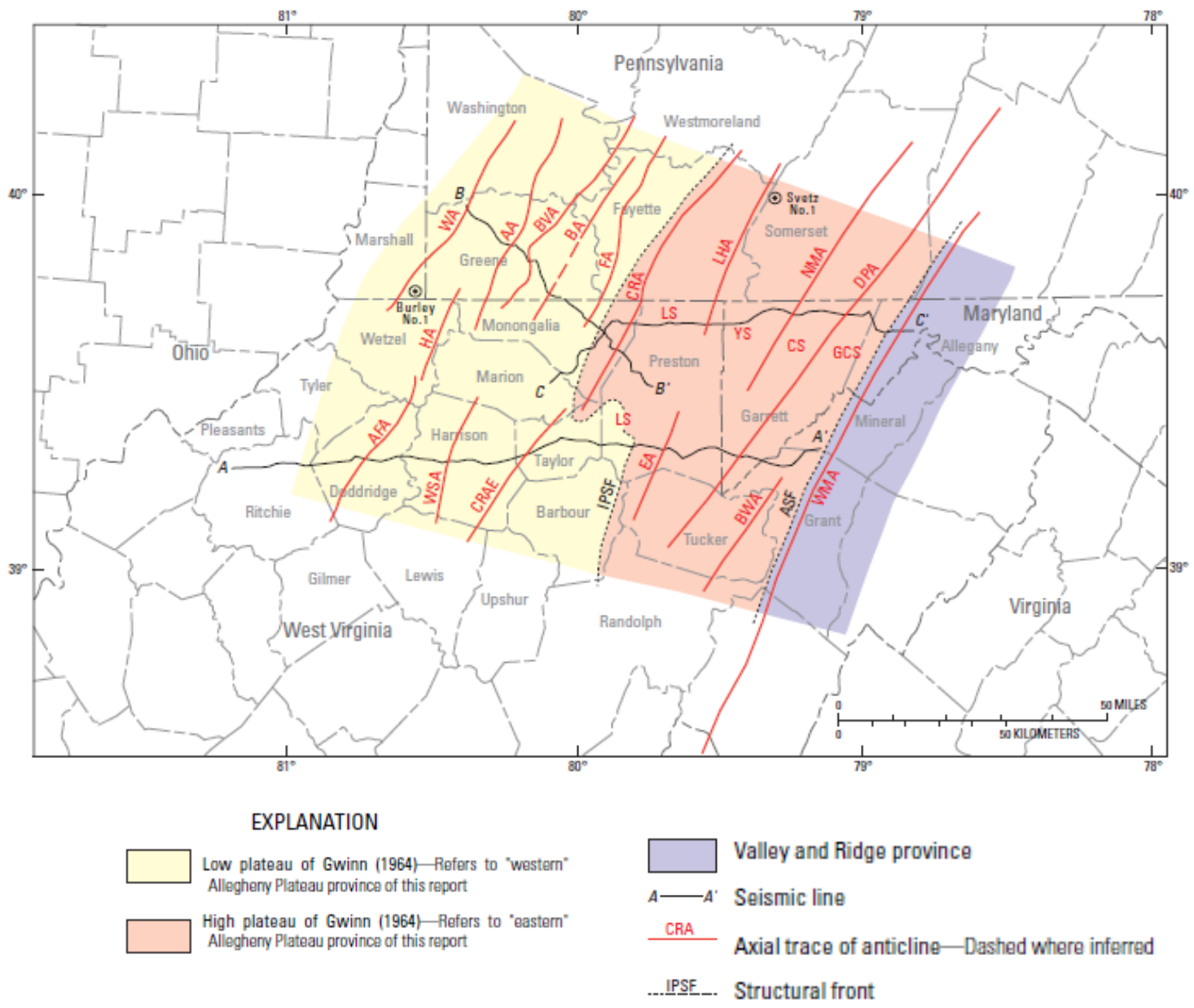

( Well location

Figure 33: Kulander and Ryder (2005) figure to show location of Burley No.1 well that has a synthetic seismogram to the basement and the location of the 2D seismic line that is near the 3D seismic surveys in this study. 


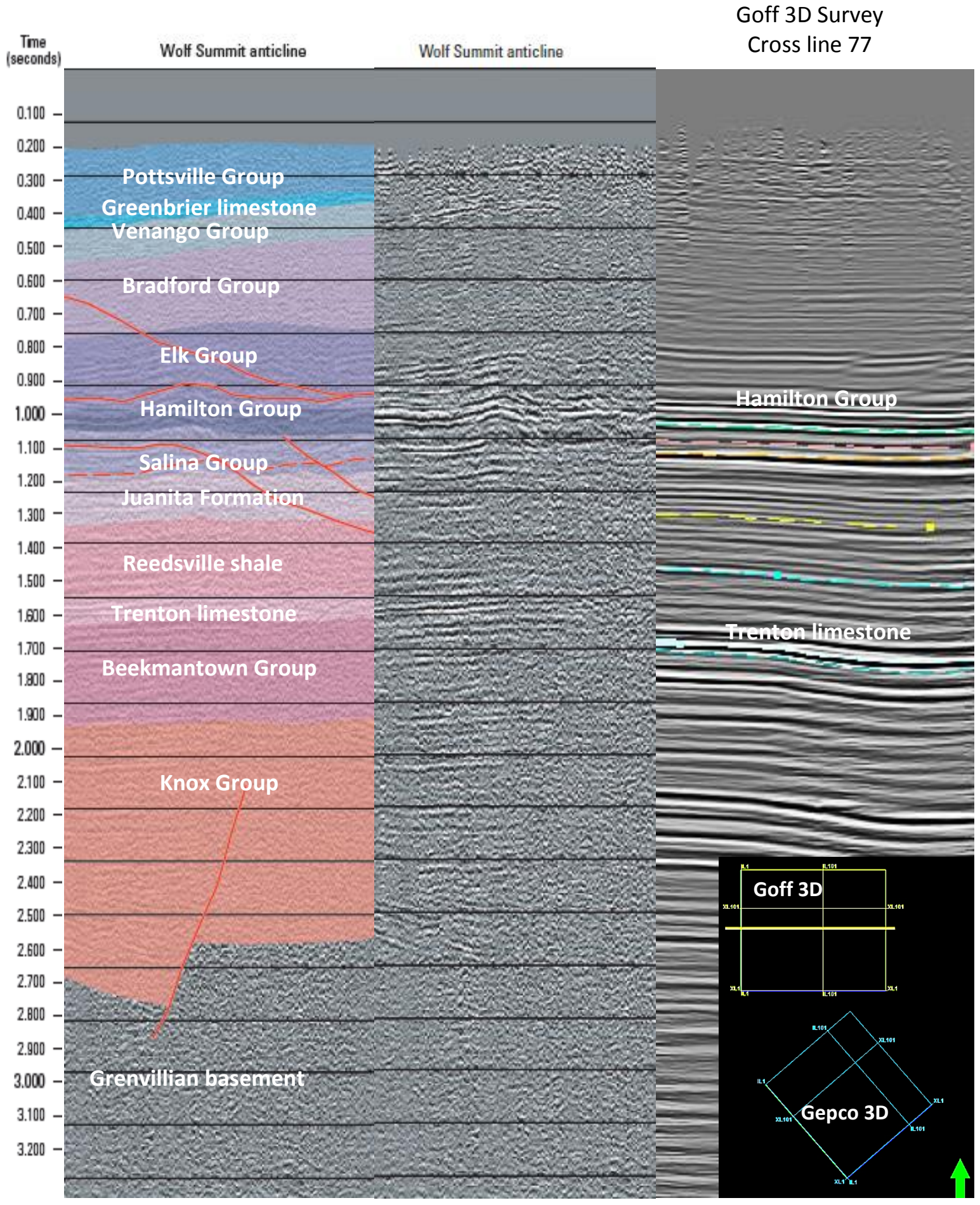

Figure 34: Kulander and Ryder (2005) regional 2D seismic line A-A' over the Wolf Summit Anticline. Left image is interpreted and middle image is uninterpretted. The right image shows the Goff 3D seismic crossline 77 with interpreted reflections. 


\subsection{Vertical Resolution}

Vertical seismic resolution is calculated using tuning time and average interval velocity. Tuning time is half of the dominant period $(\tau)$. The peak of the tuning curve produced from the extracted wavelet in the Goff 3D seismic rests at 0.011 seconds (Figure 30B). This tuning time corresponds to a dominant period of 0.022 seconds for the Middle Devonian interval within the Goff 3D seismic dataset.

Minimum resolvable thickness (MRT) is equal to one quarter of the velocity (V) times the period $(\tau)$.

$$
\mathrm{MRT}=\mathrm{V} * \tau / 4
$$

Velocity for Middle Devonian stratigraphy is plotted in Figure 35. Using this velocity information and tuning time from the seismic data, the vertical resolution limits were calculated for the Middle Devonian for the Goff 3D seismic data (Table 3). The minimum resolvable thickness for the Marcellus shale is calculated to be 58 feet. The thickness of the Marcellus shale in the Goff \#55 well is 106 feet thick, and the highest organic portion of the lower Marcellus shale is 23 feet thick (Figure 23). The Marcellus shale as a whole is within the resolvable thickness range; the lower Marcellus shale is not resolvable in this seismic dataset. Resolution for all Middle Devonian stratigraphy is summarized in Table 3. 


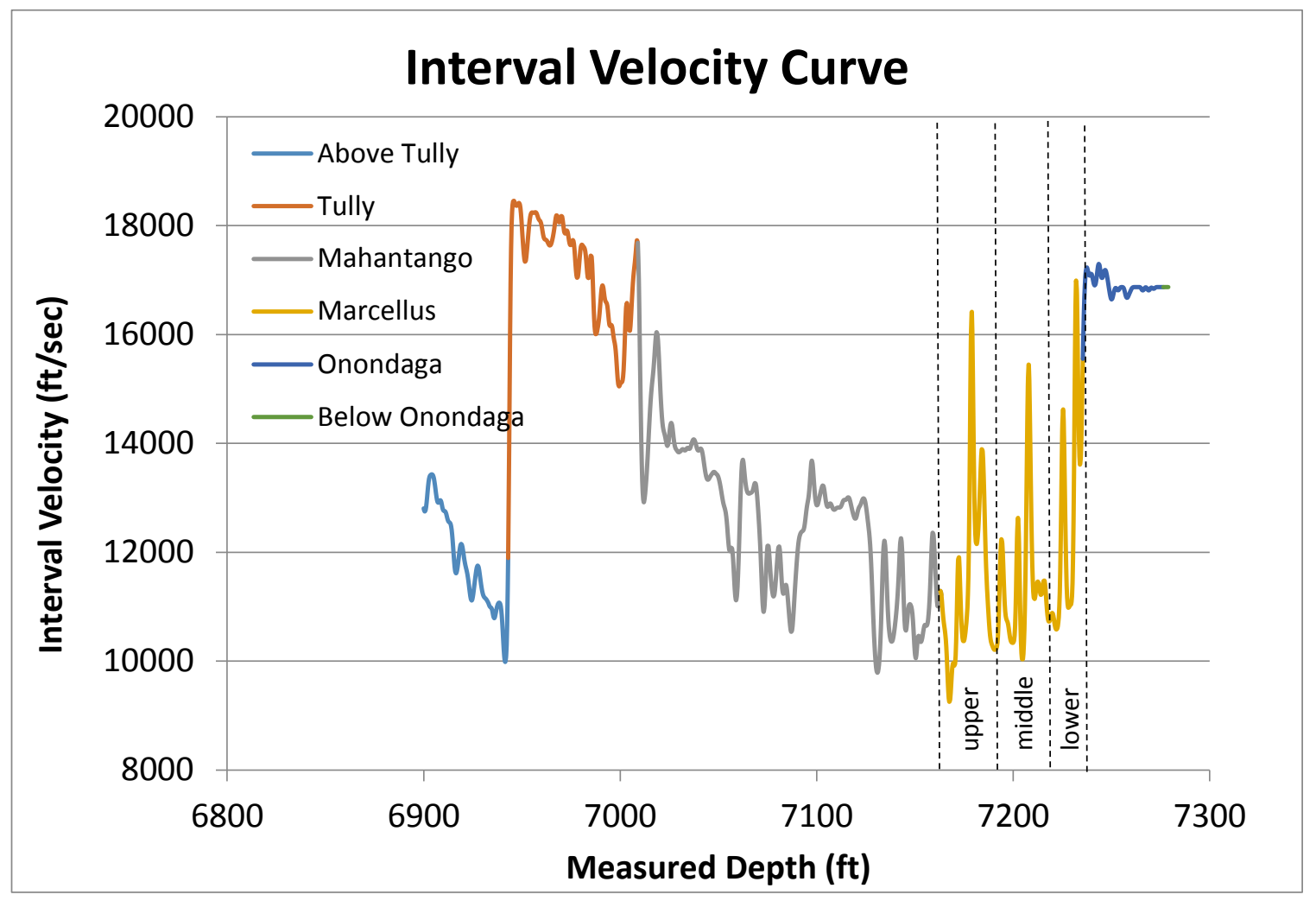

Figure 35: Velocity curve for the Middle Devonian stratigraphy at the Goff \#55 well. The Marcellus shale has an average velocity of 11,693 ft/sec and is subdivided into upper, middle and lower intervals.

\begin{tabular}{|c|c|c|c|c|c|}
\hline Stratigraphy & $\begin{array}{c}\text { Average } \\
\text { Interval } \\
\text { Velocity (V) } \\
\text { (ft/sec) }\end{array}$ & $\begin{array}{l}\text { Tuning } \\
\text { Time } \\
\text { (sec) }\end{array}$ & $\begin{array}{l}\text { Dominant } \\
\text { Period ( } \tau) \\
\text { (sec) }\end{array}$ & $\begin{array}{c}\text { Resolvable } \\
\text { Thickness } \\
\text { (MRT) } \\
\text { (ft) }\end{array}$ & $\begin{array}{l}\text { Stratigraphic } \\
\text { Thickness from } \\
\text { Logs (ft) }\end{array}$ \\
\hline $\begin{array}{l}\text { Tully } \\
\text { limestone }\end{array}$ & 17,194 & 0.011 & 0.022 & 94.6 & 66 \\
\hline $\begin{array}{l}\text { Mahantango } \\
\text { shale }\end{array}$ & 12,555 & 0.011 & 0.022 & 69.7 & 120 \\
\hline $\begin{array}{l}\text { Marcellus } \\
\text { shale }\end{array}$ & 11,693 & 0.011 & 0.022 & 64.3 & 101 \\
\hline $\begin{array}{l}\text { Onondaga } \\
\text { limestone }\end{array}$ & 16,884 & 0.011 & 0.022 & 92.9 & 41 \\
\hline
\end{tabular}

Table 3: Average interval velocity, tuning time, dominant period, resolvable thickness and stratigraphic thickness for the Middle Devonian stratigraphy in the Goff \#55 well. The Marcellus shale is resolvable in the Goff 3D seismic dataset. 


\subsection{Acoustic Log Response and Seismic Character}

Integration of 3D seismic interpretation and the petrophysical analyses completed in Chapter 3: Lithologic Analysis is completed by assessing density and sonic log response and their relationship with seismic character in context of vertical seismic resolution limits and changes in the vertical well logs. Assessing density and sonic log response is an important step to better understand the variability in seismic response as these two logs are multiplied to create acoustic impedance and seismic reflectivity, see section 4.1 Synthetic Seismogram. The integration of petrophysical analyses such as brittleness and mineralogy and the seismic response is completed in two steps. First, the Brittleness Index and mineralogical logs are related to the density and velocity logs. Then, the density and sonic logs are assessed at the wellbore with an arbitrary seismic line that directly bisects the wellbore.

The lower Marcellus has the highest average Brittleness Index, this is the zone usually targeted for hydraulic fracture stimulation. This zone corresponds to a section with relatively low bulk density, an average of $2.4 \mathrm{~g} / \mathrm{cc}$ (Figure 36 ). There are no distinct characteristics in the sonic $\log$ for this zone (Figure 36). The lower Marcellus is 23 feet thick and not resolvable in the seismic at the Goff 55 well (Figure 37). The zone of low density in the lower Marcellus shale corresponds to a transition from peak to trough in the seismic as the Onondaga limestone appears (Figure 38).

Geophysical log resolution is one half foot and seismic resolution for the Goff 3D volume is about seventy feet. No distinct correlations between log response and seismic character are discernible to identify brittle zones using solely three dimensional seismic data. However, a spectral whitened seismic volume was previously created by Petroleum Development 
Corporation in 2014 to enhance the resolution around the Marcellus shale (Figure 39). The increased resolution brings out internal stratigraphy and may bring more insights into correlation of seismic with geophysical logs and rock properties such as brittleness. This is discussed in Chapter 8: Future Work. 


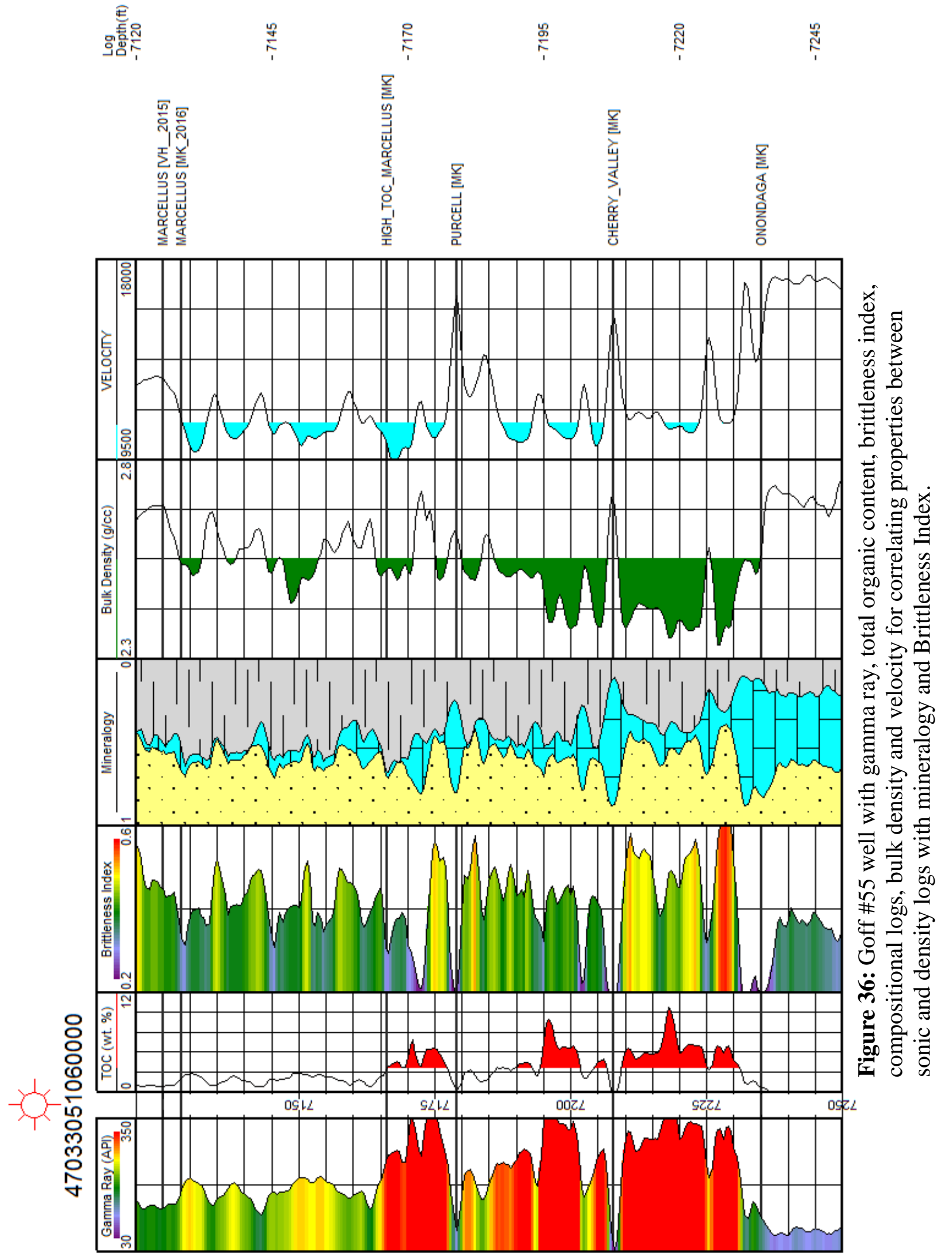




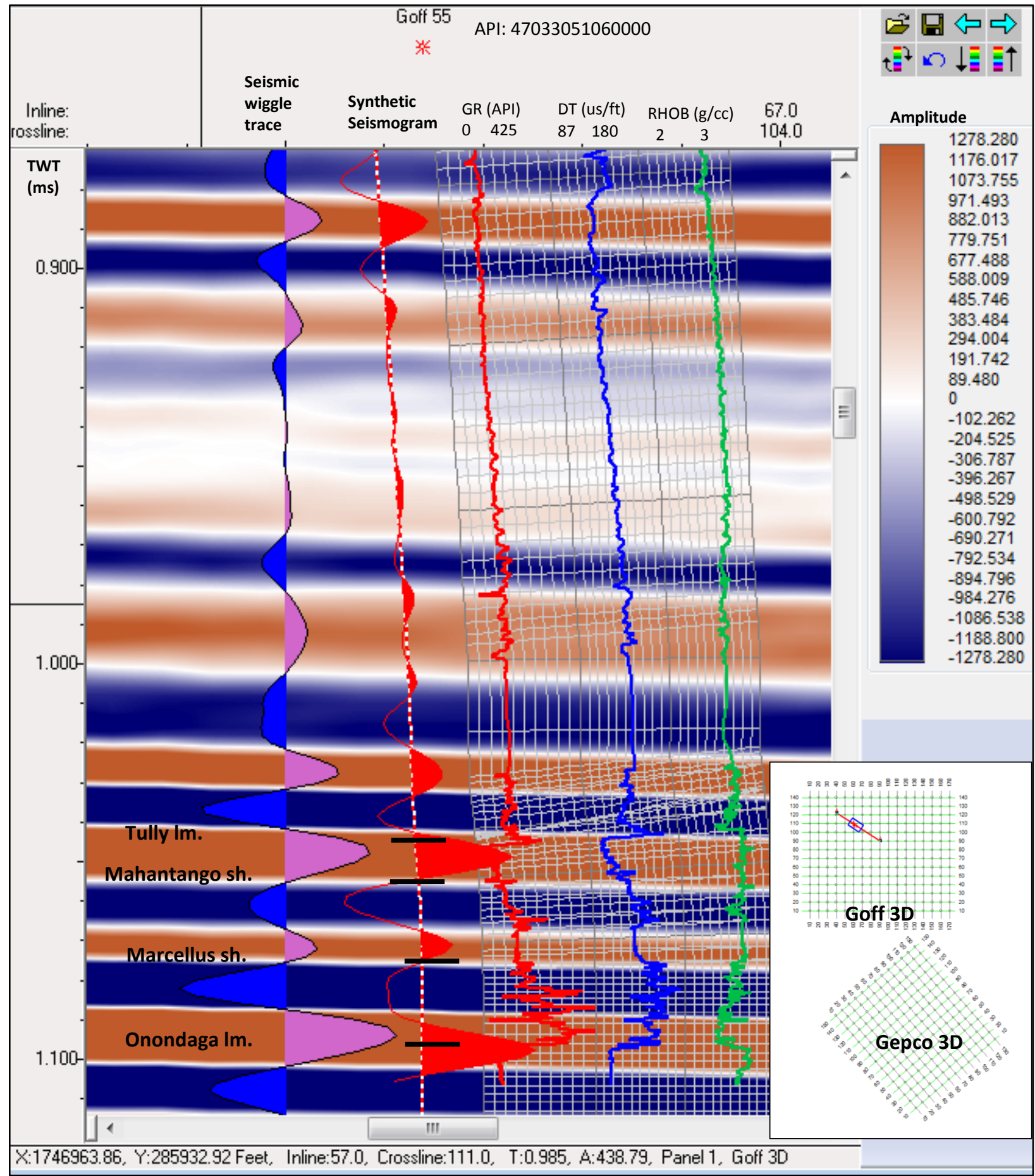

Figure 37: Synthetic seismogram displayed on the Goff 55 well path at an arbitrary line in the Goff 3D seismic survey. A seismic wiggle trace is highlighted to compare to the generated synthetic. The gamma ray, sonic and density logs are also displayed for correlation with seismic character. The location of this seismic profile is outlined in blue on the seismic reference map. 


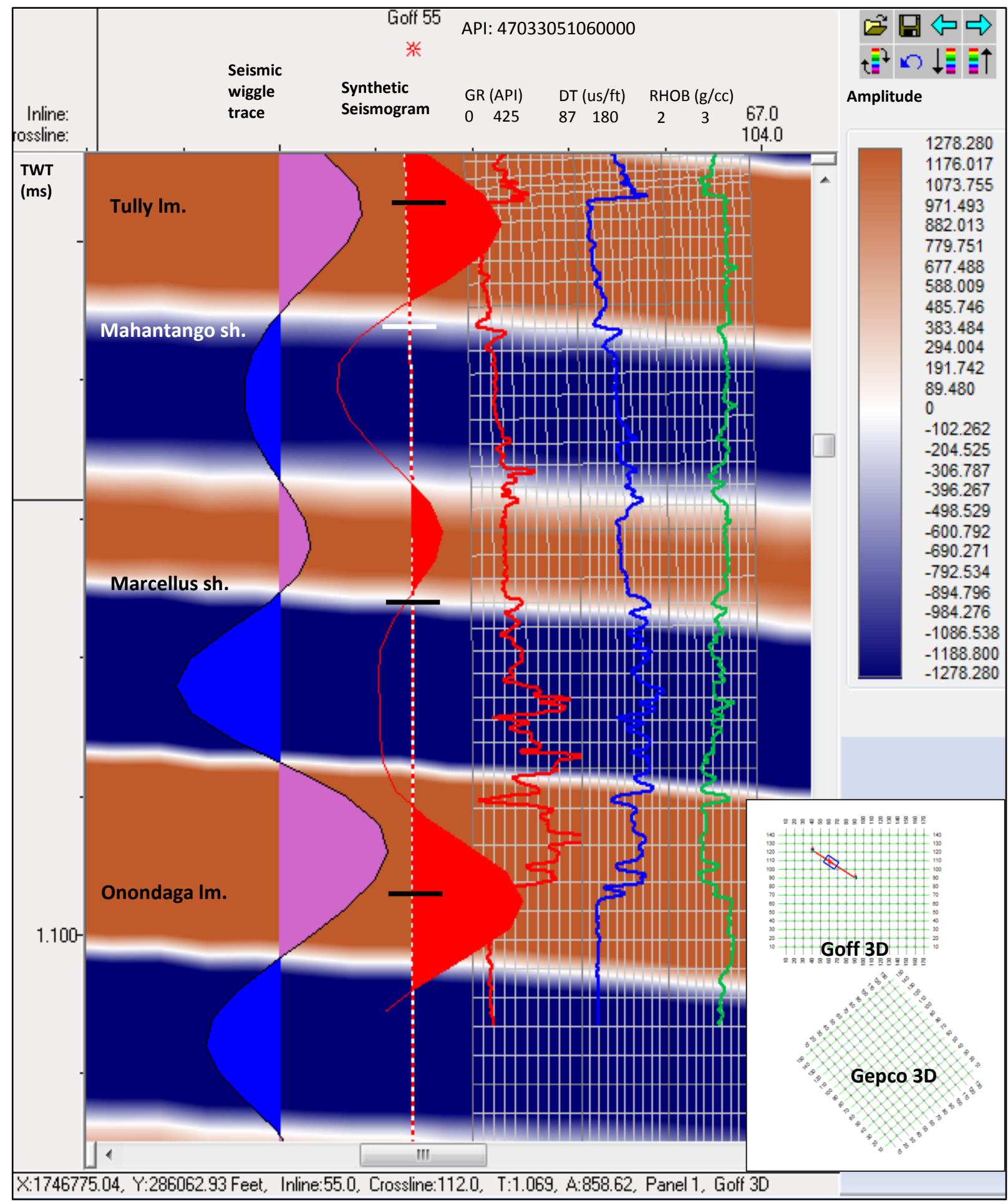

Figure 38: Middle Devonian zoomed in view of the synthetic seismogram displayed on the Goff 55 well path at an arbitrary line in the Goff 3D seismic survey. A seismic wiggle trace is highlighted to compare to the generated synthetic. The gamma ray, sonic and density logs are also displayed for correlation with seismic character. The location of this seismic profile is outlined in blue on the seismic reference map. 


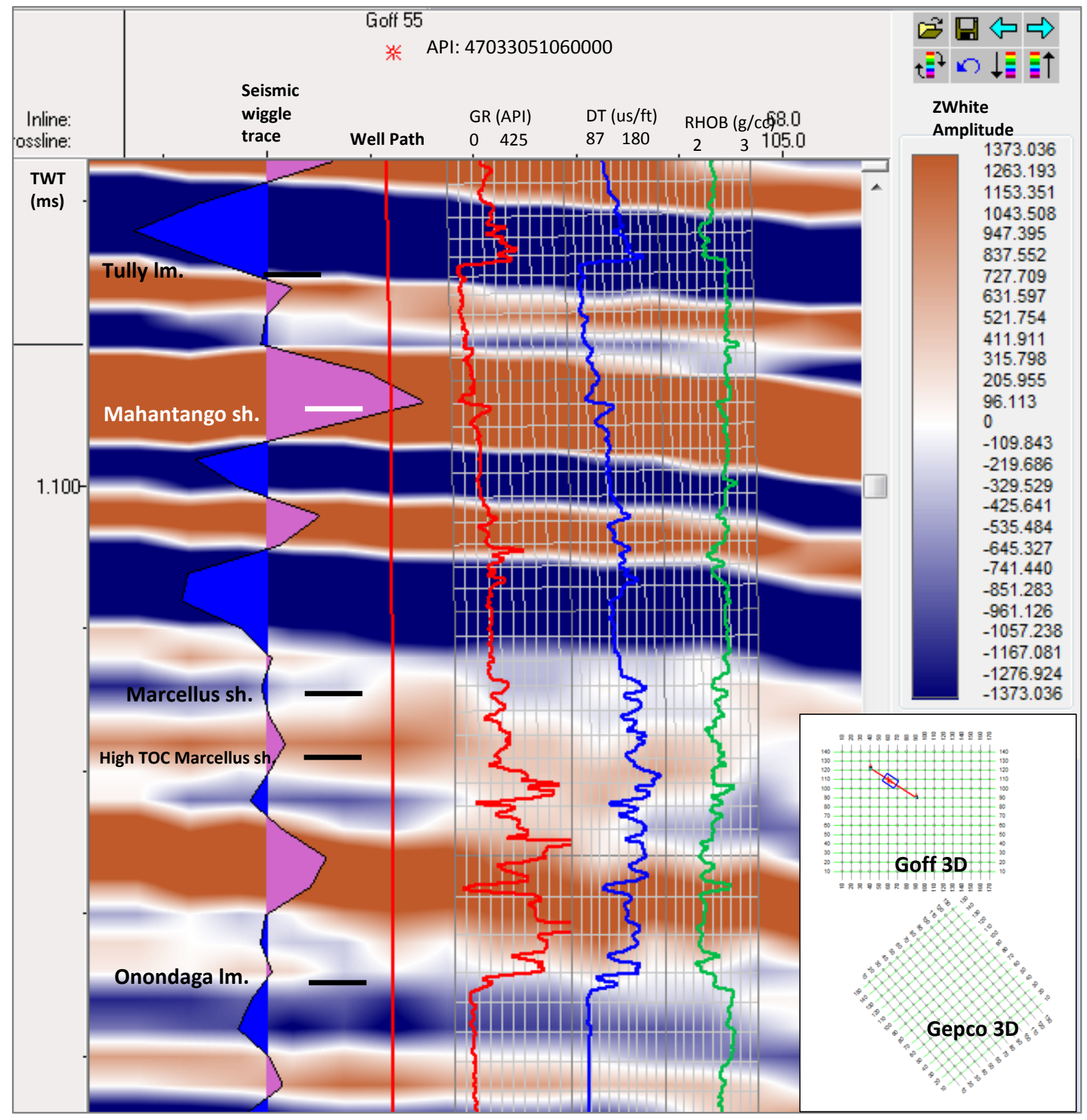

Figure 39: Goff 55 well path and seismic wiggle trace is highlighted on an arbitrary seismic line of a spectral whitening volume of the Goff 3D. The gamma ray, sonic and density logs are also displayed for correlation with this seismic character. The location of this seismic profile is outlined in blue on the seismic reference map. 


\section{SEISMIC INTERPRETATION}

\subsection{Seismic Structure Maps}

The reflection pattern of Middle Devonian stratigraphy consists of a series of parallel to subparallel reflection events. The reflection events exhibit moderate continuity and medium to high amplitude. The most positive amplitudes are observed at the change from shale to limestone lithology due to the increase in velocity and density, such as the transition from the base of the Marcellus shale to the top of the Onondaga limestone. The near parallel nature of the reflectors indicates that Middle Devonian stratigraphy was deposited locally at a uniform rate. Slight divergence from parallel reflection creates a low angle wedge in some stratigraphy which thickens to the east. The top and base of the Marcellus shale are mapped to analyze structure across the study area (Figures 40 and 41). The base of the Marcellus shale is the Onondaga limestone structure map. Seismic structure maps were converted from the time domain to the depth domain using a velocity model in Petrel that employed average velocities obtained from the Burley well in Marshall County West Virginia (Table 4). Marcellus shale wells are displayed on both the top of the Marcellus shale and base of the Marcellus shale structure maps, although the landing of the horizontal well is in-between these two surfaces.

\begin{tabular}{|l|l|}
\hline Horizon Name & Average Velocity from Surface (ft/sec) \\
\hline Marcellus shale & 13732.36 \\
\hline Onondaga limestone & 13716.09 \\
\hline Trenton limestone & 14632.69 \\
\hline Black River limestone & 14657.39 \\
\hline
\end{tabular}

Table 4: Average velocity used to convert two-way time seismic structure maps into the depth domain. 
The location of the Wolf Summit Anticline is interpreted as the structural high on the northwest corner of the Goff 3D which is the shallowest area of the Marcellus shale. The shallow areas are indicated by warm colors and relatively deeper areas are indicated by cool colors (Figures 40 and 41). The axis of the Wolf Summit Anticline (WSA) is not on the seismic surveys. Currently, there are no Mountaineer Keystone wells drilled in close proximity to the axis of the Wolf Summit Anticline (Figures 40 and 41).

A low amplitude northeast trending synclinal structure is observed in the Marcellus shale and Onondaga limestone seismic structure maps between the Goff 3D and Gepco 3D seismic surveys (Figures 40 and 41). This structure is interpreted as the Shinnston Syncline (SS).

The Marcellus shale structure map exhibits a vertical change of 320 feet in the top of the Marcellus shale surface across the 7.8 miles spanning the two seismic surveys. The Onondaga limestone structure map also exhibits a vertical change of 320 feet which corresponds to the base of the Marcellus shale surface. Thickness changes in the Marcellus shale are further discussed in Section 5.4 Isochore Maps (Figure 49). Marcellus shale production analysis in context of structure is discussed in Section 6.2.1 Analysis of Existing Marcellus Shale Wells (Figure 79).

The reflection pattern of the Middle Ordovician strata is a series of parallel to subparallel reflection events. The Trenton limestone has a vertical change of 500 feet for the top and 475 feet for the base which is comparatively more vertical structure change than the Marcellus shale surface (Figures 42 and 43). An arbitrary seismic line is shown perpendicular to the structural trend of the Trenton limestone surface in section 5.3 Fault Interpretation (Figure 47). 


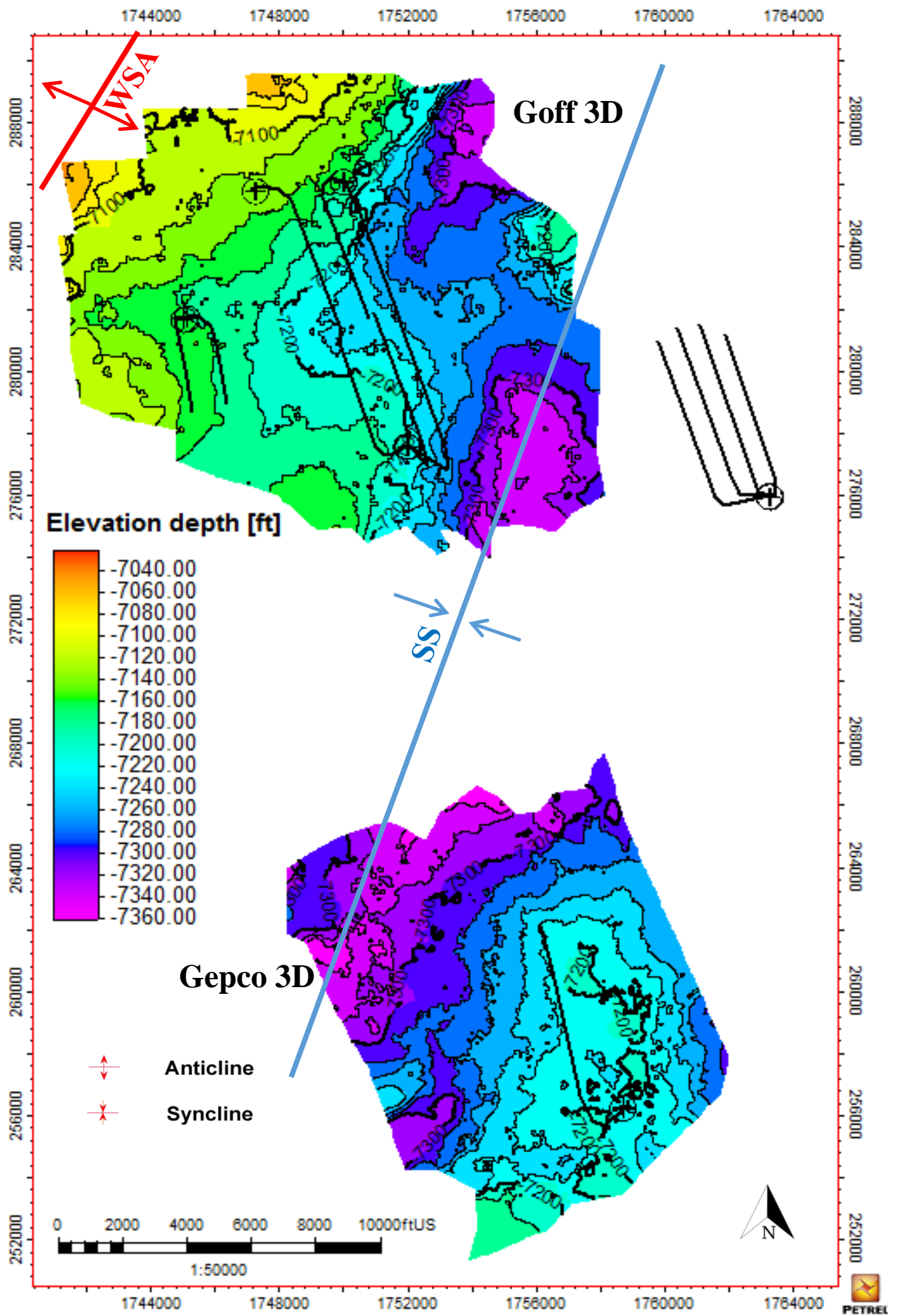

Figure 40: Marcellus shale seismic horizon which represents the geologic subsurface map of the structure of the top of the Marcellus shale. Relatively deep is indicated by purple while relatively shallow is indicated by red. The Wolf Summit Anticline (WSA) and Shinnston Syncline (SS) are labeled. This map is the top of the Marcellus shale and the location of horizontal wells are shown for reference only. 


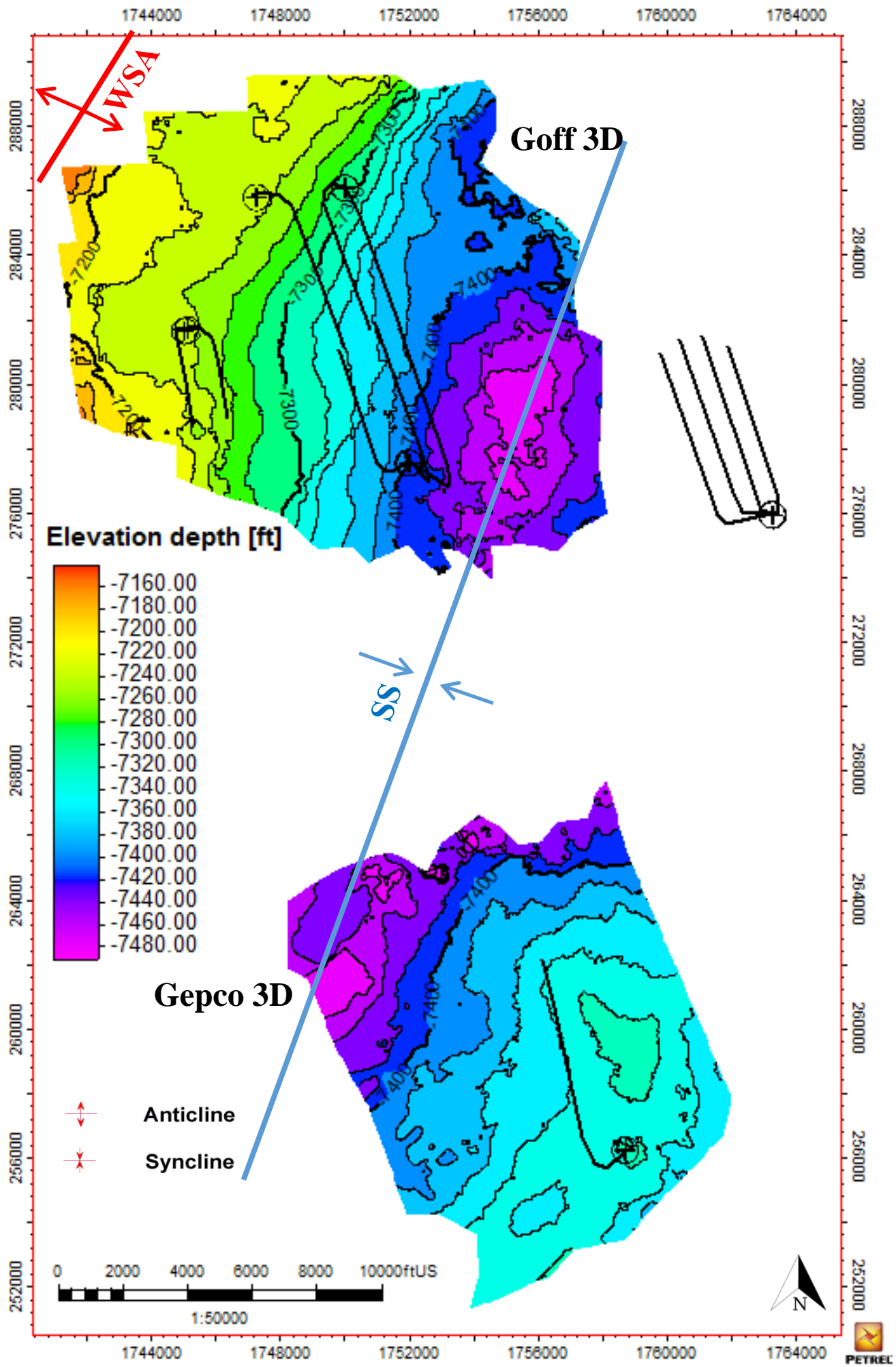

Figure 41: Onondaga limestone seismic horizon which represents the geologic subsurface map of the structure of the base of the Marcellus shale. Relatively deep is indicated by purple while relatively shallow is indicated by red. The Wolf Summit Anticline (WSA) and Shinnston Syncline (SS) are labeled. This map is the top of the Onondaga limestone and the location of horizontal wells are shown for reference only. 


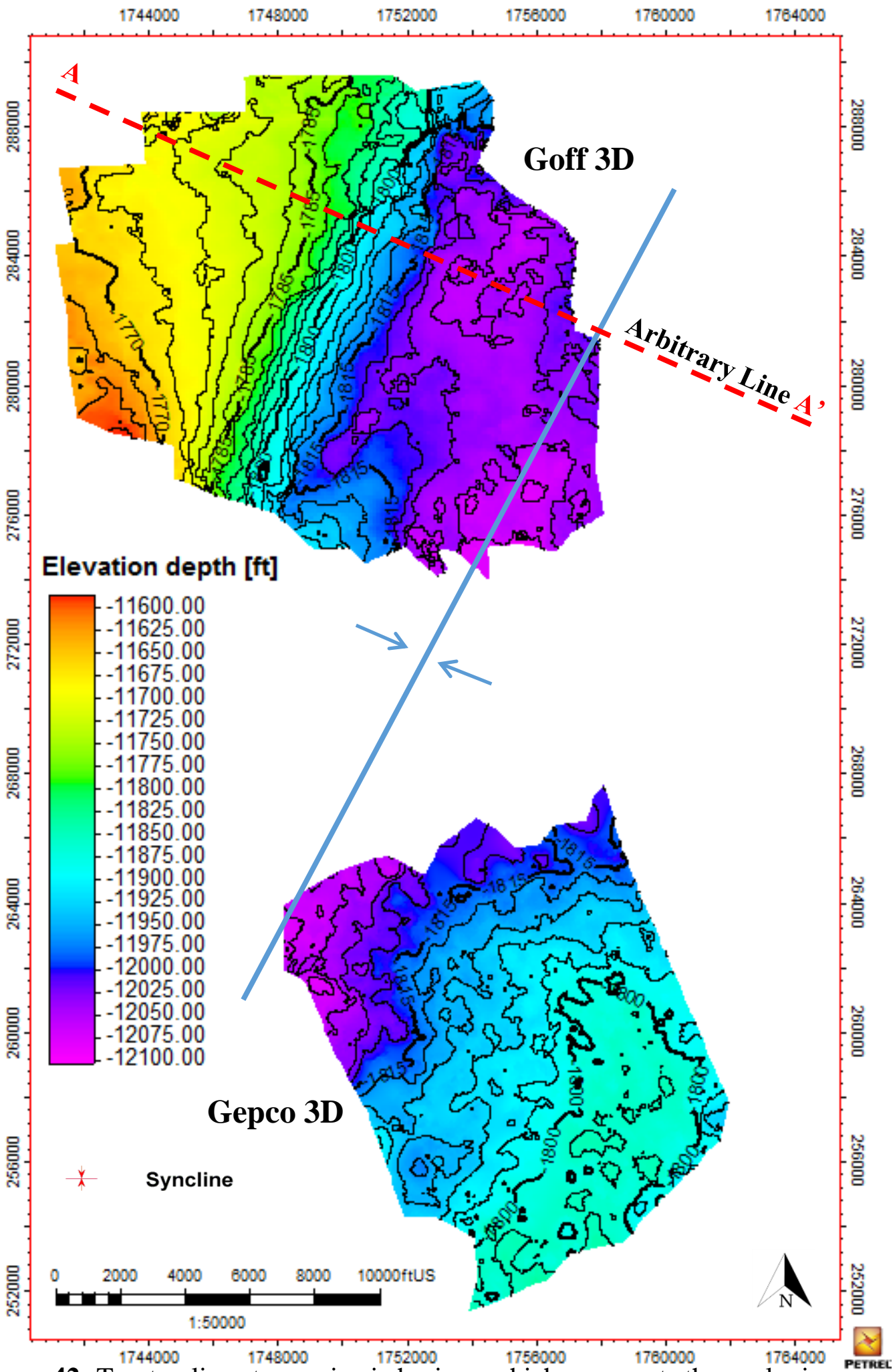

Figure 42: Trenton limestone seismic horizon which represents the geologic subsurface map of the structure of the top of the Trenton limestone. Relatively deep is indicated by purple while relatively shallow is indicated by red. Deep areas at the edge of both surveys show a synclinal feature between the two. 


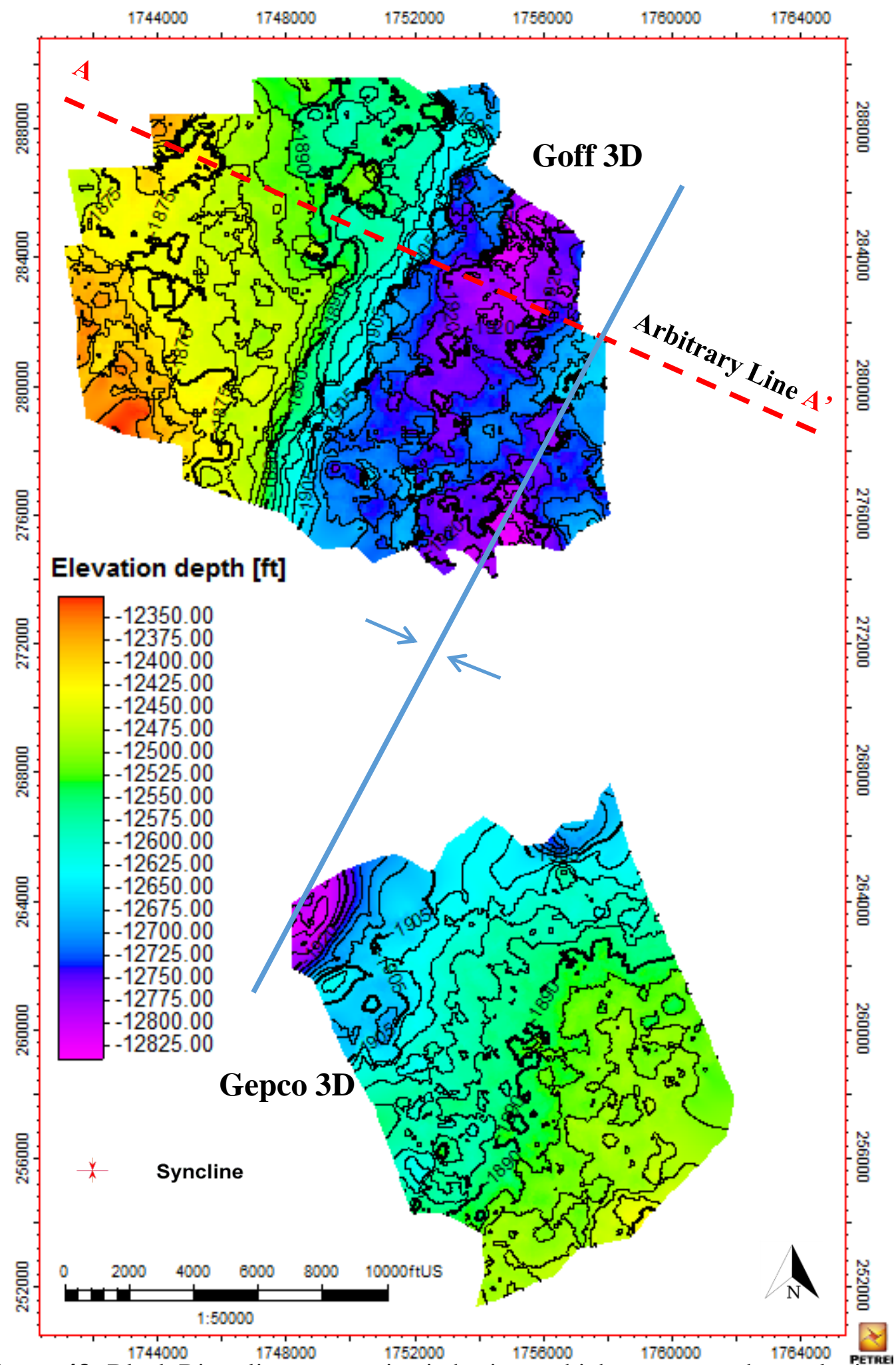

Figure 43: Black River limestone seismic horizon which represents the geologic subsurface map of the structure of the base of the Trenton limestone. Relatively deep is indicated by purple while relatively shallow is indicated by red. Deep areas at the edge of both surveys show a synclinal feature between the two. 


\subsection{Dip Angle Maps}

Generally the Middle Devonian reflectors are horizontal with dips not exceeding four degrees (Figures 44 and 45). The northeastern quadrant of the Goff 3D Marcellus shale dip map contains a series of northeast trending lineaments with a higher dip angle relative to the rest of the survey. These lineaments are shown in a red color which represents a dip on the Marcellus shale surface greater than ten degrees (Figure 44). The Marcellus shale dip map also has an area near the southeastern well pad that has a dip of less than four degrees, shown by the bright blue region. The Onondaga limestone dip map has similar northeast trending lineaments in the northeast quadrant in the Goff 3D that extend more to the southwest (Figure 45). The area of one degree dip in the Marcellus shale map in the southeastern well pad is not apparent on the Onondaga dip map. The Gepco 3D survey exhibits variable dip for the Marcellus surface. The Onondaga dip is mostly zero for the Gepco 3D except for the north most portion of the survey. Generally the Onondaga has more uniform areas of dip less than one degree compared to the Marcellus which has more variable dip angles. This may be interpreted as the Onondaga limestone being a more competent unit and the Marcellus shale experienced more subtle structural deformation.

The Trenton limestone top and base contains a northeast trending normal fault across the Goff 3D survey shown by the area with high dip angle (Figures 46 and 47). The Trenton limestone dip in the Gepco 3D is variable and no major lineaments are observed. The northeast tending fault in the Trenton across the Goff 3D results in deformation up section creating the northeast trending lineaments in the northeast quadrant of the Goff 3D on the Onondaga and Marcellus reflectors. 


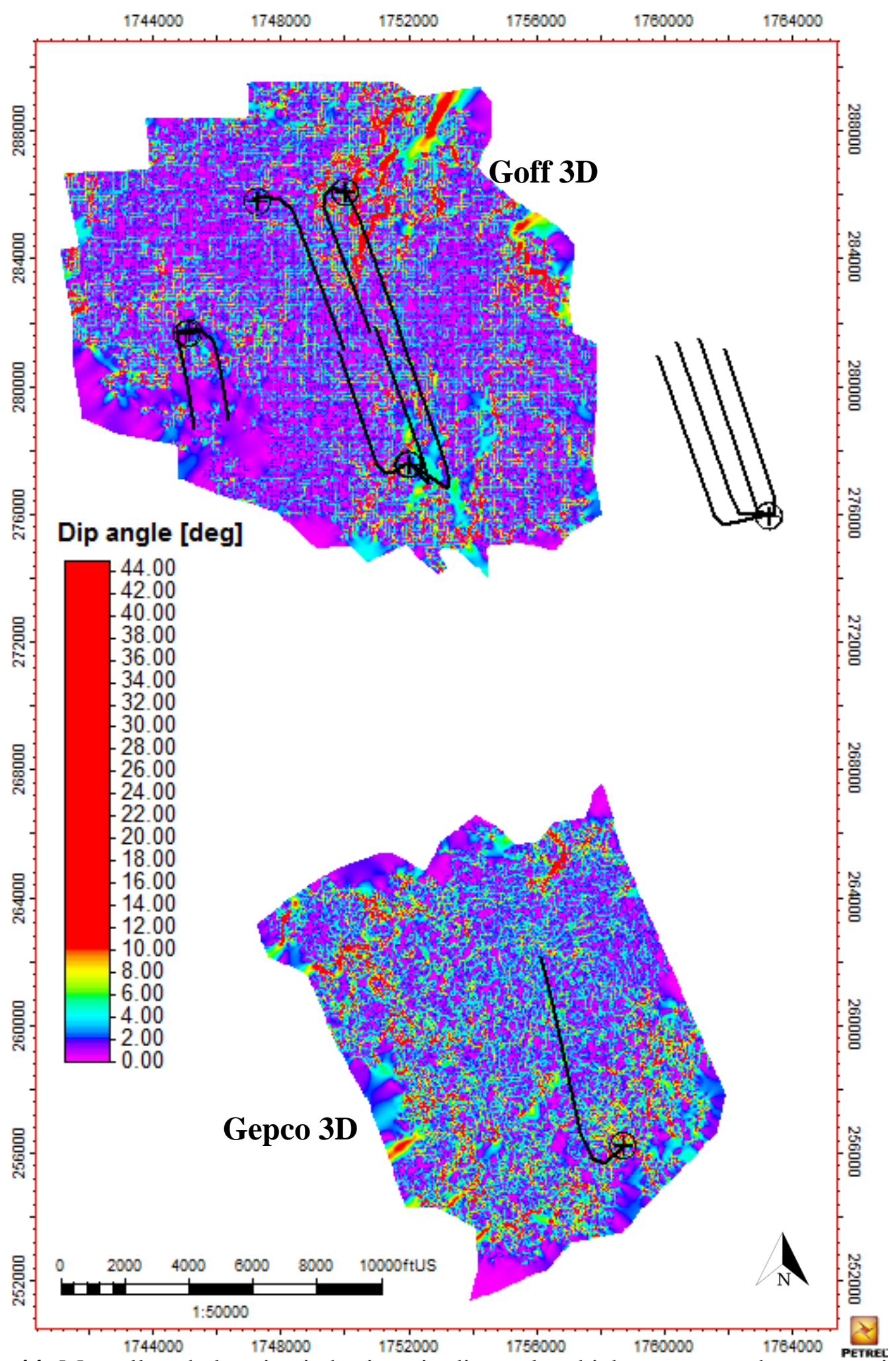

Figure 44: Marcellus shale seismic horizon in dip angle which represents the amount in degrees of dip of the subsurface horizon of the top of the Marcellus shale. Blue and purple indicate a nearly flat horizon with a dip of less than four degrees. The location of horizontal wells are shown for reference. 


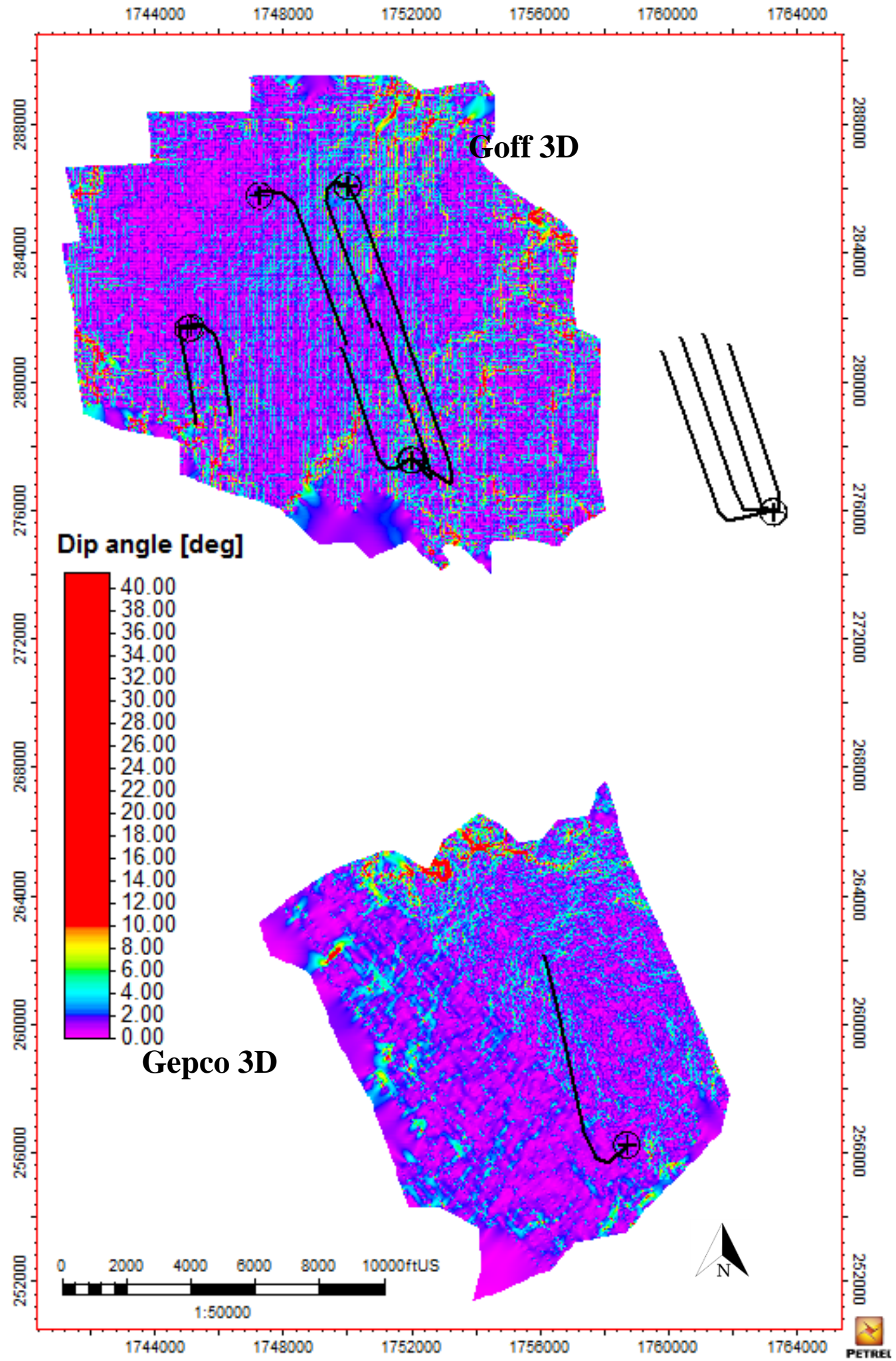

Figure 45: Onondaga limestone seismic horizon with dip angle attribute which represents the amount in degrees of dip of the subsurface horizon of the base of the Marcellus shale. Blue and purple indicate a nearly flat horizon with a dip of less than four degrees. The location of horizontal wells are shown for reference. 


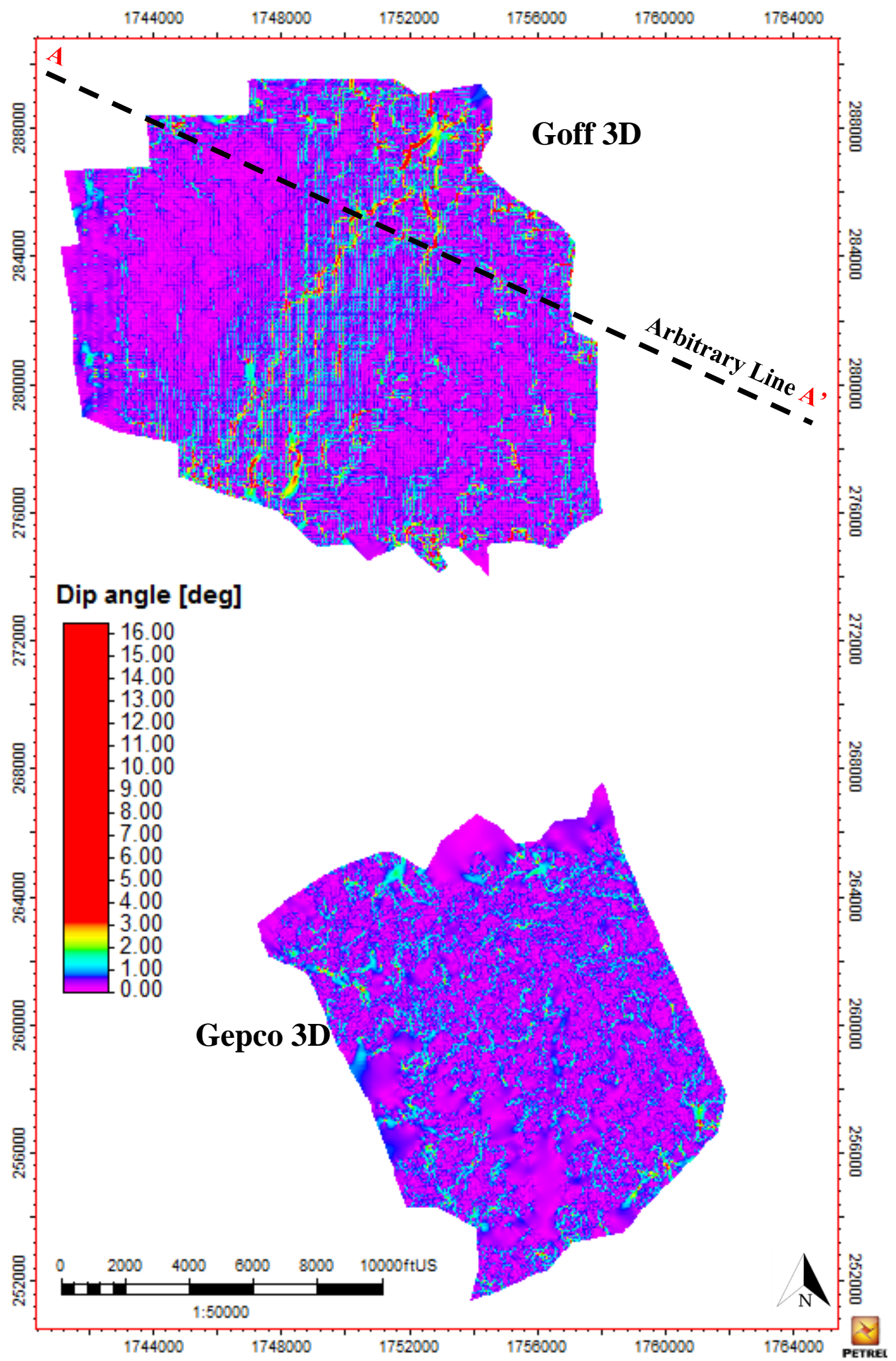

Figure 46: Trenton limestone seismic horizon in time dip angle which represents the amount in degrees of dip of the subsurface horizon of the top of the Trenton limestone. Blue and purple indicate a nearly flat horizon with a dip of less than one degree. 


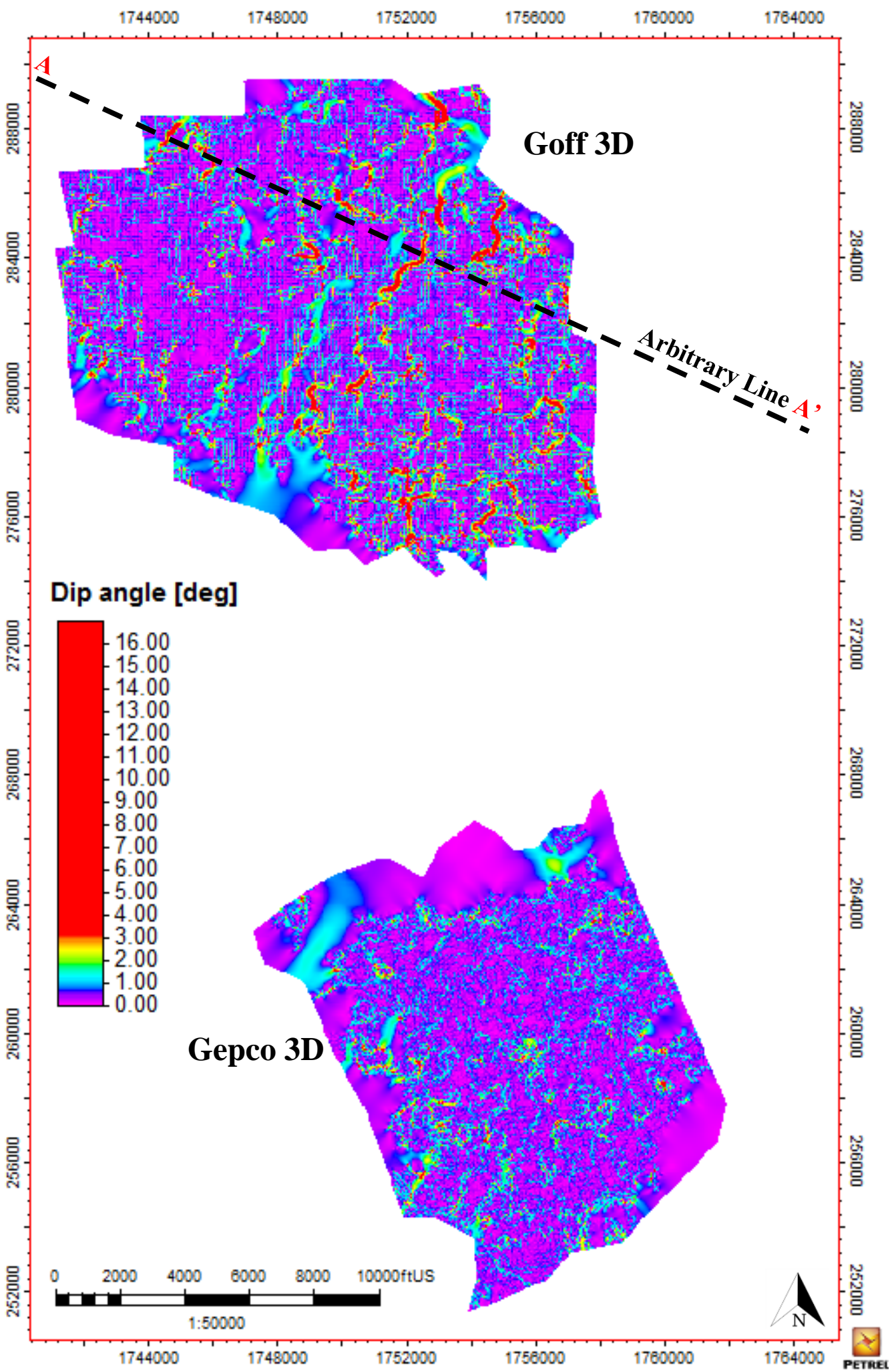

Figure 47: Black River limestone seismic horizon in dip angle which represents the amount in degrees of dip of the subsurface horizon of the base of the Trenton limestone. Blue and purple indicate a nearly flat horizon with a dip of less than one degree. 


\subsection{Fault Interpretation}

Faults were interpreted in the Goff 3D with aid of variance and time variant trace amplitude slicing (TVTAS) seismic volumes (Figure 48). The variance seismic attribute assesses trace to trace variability to analyze lateral continuity. Variance was used in the time slice view to confirm the location of faults. TVTAS is a post stack seismic processing workflow that is used to highlight the location of subtle faults and fracture zones in the vertical direction (Wilson et al., 2012, 2013, 2016). The Goff 3D TVTAS volume was prepared for this study by Dr. Thomas Wilson in November 2015.

Three major thrust sheets are observed in the Appalachian basin: the Rome-Waynesboro, Reedsville-Martinsburg and Salina sheets (Kulander and Ryder, 2005). Major detachment occurs along mechanically weak layers in these sheets. Figure 49 shows a seismic section from the Goff 3D with interpreted minor and major partial detachment and normal faulting from the interpreted basement surface up section through the Elk Group.

Above the Grenvillian basement the Lower Cambrian Rome shale acts as a detachment horizon. Two small normal faults create a small graben in the Early Cambrian Knox Group indicative of the extensional rift during this period (Figure 49). The Knox Group is partially broken by these normal faults. Above the Knox Group is the Beekmantown Group. The Beekmantown Group also contains normal faults but are more vertically continuous than the normal faults observed in the Knox Group (Figure 47). During this time the basin was in a passive margin setting experiencing slow differential subsidence. Above the Beekmantown Group is the high amplitude reflection of the Trenton limestone. In this dataset, the Trenton limestone is a continuous reflection event that rarely has faults causing offset in the horizon 
(Figure 49). However, deeper extensional faults cause folding in the Trenton limestone where the eastern block was subsiding during rifting. Above the Trenton limestone is the Reedsville shale which is non-continuous and low amplitude reflector and acts as a major detachment (Figure 49). A major thrust is observed above the Reedsville shale that terminates in the Reedsville shale. During this time the Taconic orogeny took place creating compressional stress from the east. The Salina Group is another major thrust sheet in this basin, however no major thrusts are observed in this study area in the Salina. The top of the Hamilton Group acts as the basal decollement for two reverse faults in the Elk Group (Figure 49).

Three major phases of deformation during the Paleozoic as described by Gao et al. (2000) resulted in vertical stacking of structural styles and depositional sequences which are observed in this study area. First, the Precambrian and Early Cambrian extensional faulting caused the eastern portion of this area to subside creating accommodation space and thickening of sediments. Then, during the Middle Ordovician with the closing of the Iapetus Ocean the Taconic orogeny created a compressional regime in this area (Section 2.1.1 Orogenic Events). Some of the early normal faults were reactivated with a reversed movement pushing the eastern block back up. This is observed by thinning of sediments in the eastern block during this time period, see more in section 5.4 Isochore Maps. Finally, from Late Ordovician through Pennsylvanian time inversion structures began to form with the Taconic orogeny and formation of the Appalachian foreland basin (Gao et al., 2000).

A vertical trend in the location of faults around crossline 84 in the Goff 3D indicates that preexisting Precambrian faults in this area may have acted as nucleation points for future deformation (Figure 50). This is shown by the complexity of faulting between the interpreted 
basement horizon and the Trenton limestone horizon (Figure 50). Faults were picked in Petrel by observing reflection offsets and are mapped in Figure 50. The series of smaller faults that were mapped are believed to all be related to reactivation of the major basement fault in this area.

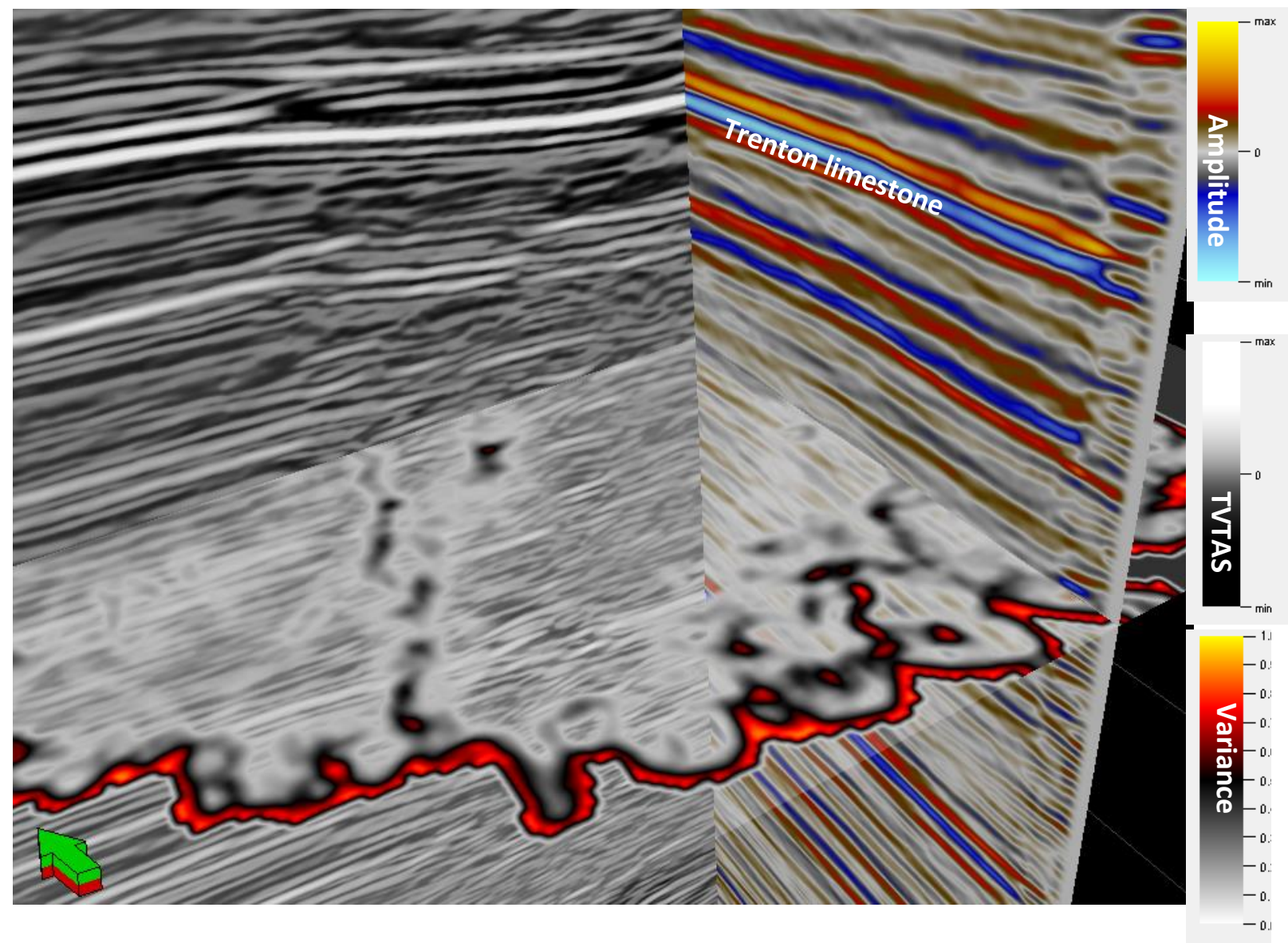

Figure 48: Petrel 3D Window view of the workflow process for interpreting faults with 20x vertical exaggeration as viewed from the southeast. Seismic amplitude, TVTAS and variance volumes are all used to assess the location of a fault below the Trenton limestone reflection event in the Goff 3D. 


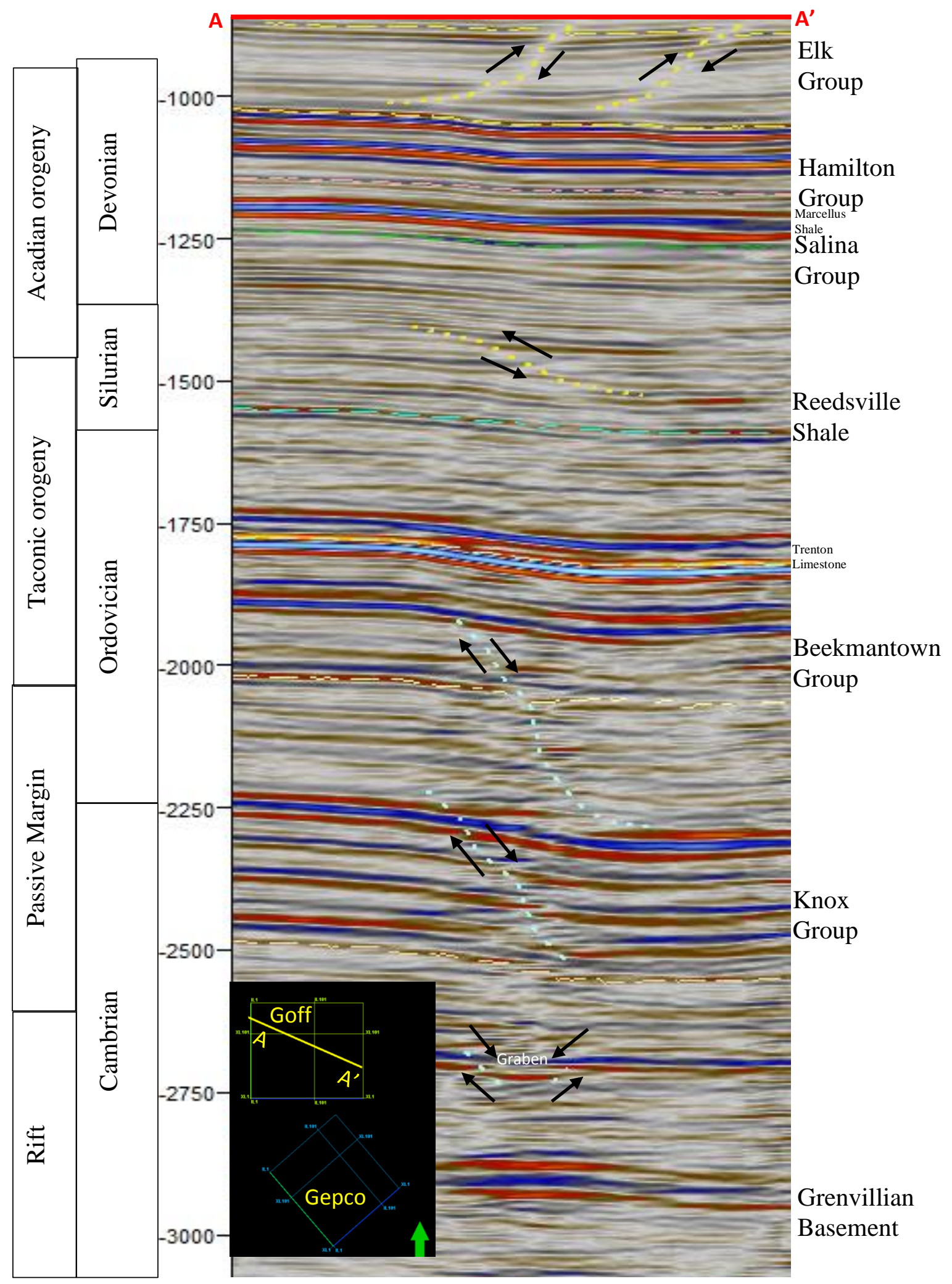

Figure 49: Petrel Interpretation Window of the Goff 3D seismic dataset at an arbitrary line A-A' perpendicular to the northeast trending structure observed in structure maps. Extensional faults are colored blue and compressional faults are colored yellow. 


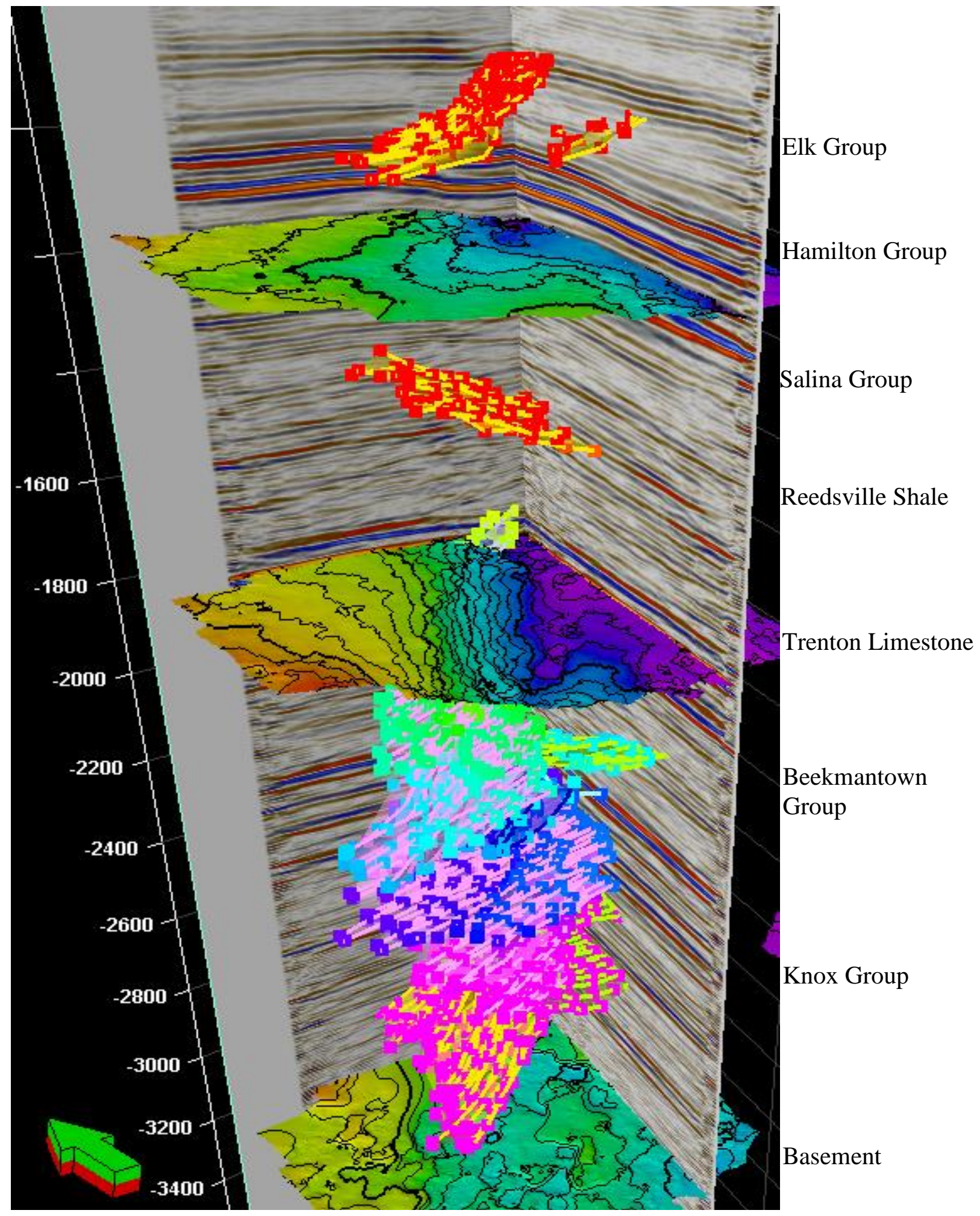

Figure 50: Petrel 3D Window showing the Goff 3D and interpreted faults form the Elk Group to the Grenvillian basement. The three horizons shown from shallow to deep are the Marcellus shale, Trenton limestone and interpreted basement. This figure depicts the complicated multilevel fault stacking between the Trenton limestone and the basement. 


\subsection{Isochore Maps}

Isochore maps are used to show the interpreted thickness between two seismic horizons. Contours on isochore maps show the depth difference, in feet, of two seismic structure maps. Isochore maps provide insight into paleostructure, the depositional period of stratigraphic intervals, and timing of deformation events (Gadallah and Fisher, 2009). For this study, isochore maps were created for two purposes.

The first purpose is to create thickness maps of the Marcellus shale and Trenton limestone. Subsequent analysis of these isochore maps are used to reveal the periodic movement of a basement fault block in the Rome trough that underlies the play. Reactivation of this fault block during the Paleozoic produces thickening or thinning of intervals in the overlying section. These episodic movements may influence the distribution of shale gas sweet spots and current gas well production from the Marcellus shale. The location of the deeper structure and the history of its movements may provide insights during planning of future well locations.

The Marcellus shale isochore thickness map (Figure 51) shows thickening in the Goff 3D in the location of the Shinnston syncline (Figure 40, Section 5.1 Seismic Structure Maps). Thickening in the syncline reaches 220 feet thick doubling the average thickness in this region. The average thickness of the Marcellus shale within both seismic surveys is 110 feet which coincides with published thickness values in that region (Figure 10, Section 2.3 Marcellus Shale). Thickening in the region of the syncline indicates uplift of the western block during time of Marcellus deposition. The Gepco 3D has uniform Marcellus shale thickness averaging 110 feet. Uplift and thickening observed in the Goff 3D is caused by reactivation of a basement fault 
which is further discussed in this section. No large faults are observed in the Gepco 3D resulting in the uniform thickness.

Within the Goff 3D eight horizontal wells from four well pads cross different zones of Marcellus shale thickness. Lateral length normalized first year cumulative production is discussed in context of Marcellus shale thickness and the local depocenter in Section 6.2.1: Analysis of Existing Marcellus Shale Wells. There was no correlation found between Marcellus shale thickness and first year length normalized cumulative gas production.

The Trenton limestone isochore thickness map (Figure 52) depicts variable thickness throughout the Goff 3D ranging on average from 750 feet to 650 feet thick. The Gepco 3D shows more uniform thickness averaging 650 feet thick in the Trenton limestone than the variable thickness observed in the Goff 3D. The northeast trending lineament of thinning observed in the Trenton limestone in the Goff 3D is associated with the same fault causing thickening in the Marcellus shale thickness map. Again, no faults are observed in the Gepco 3D resulting in more uniform thickness in this region. 


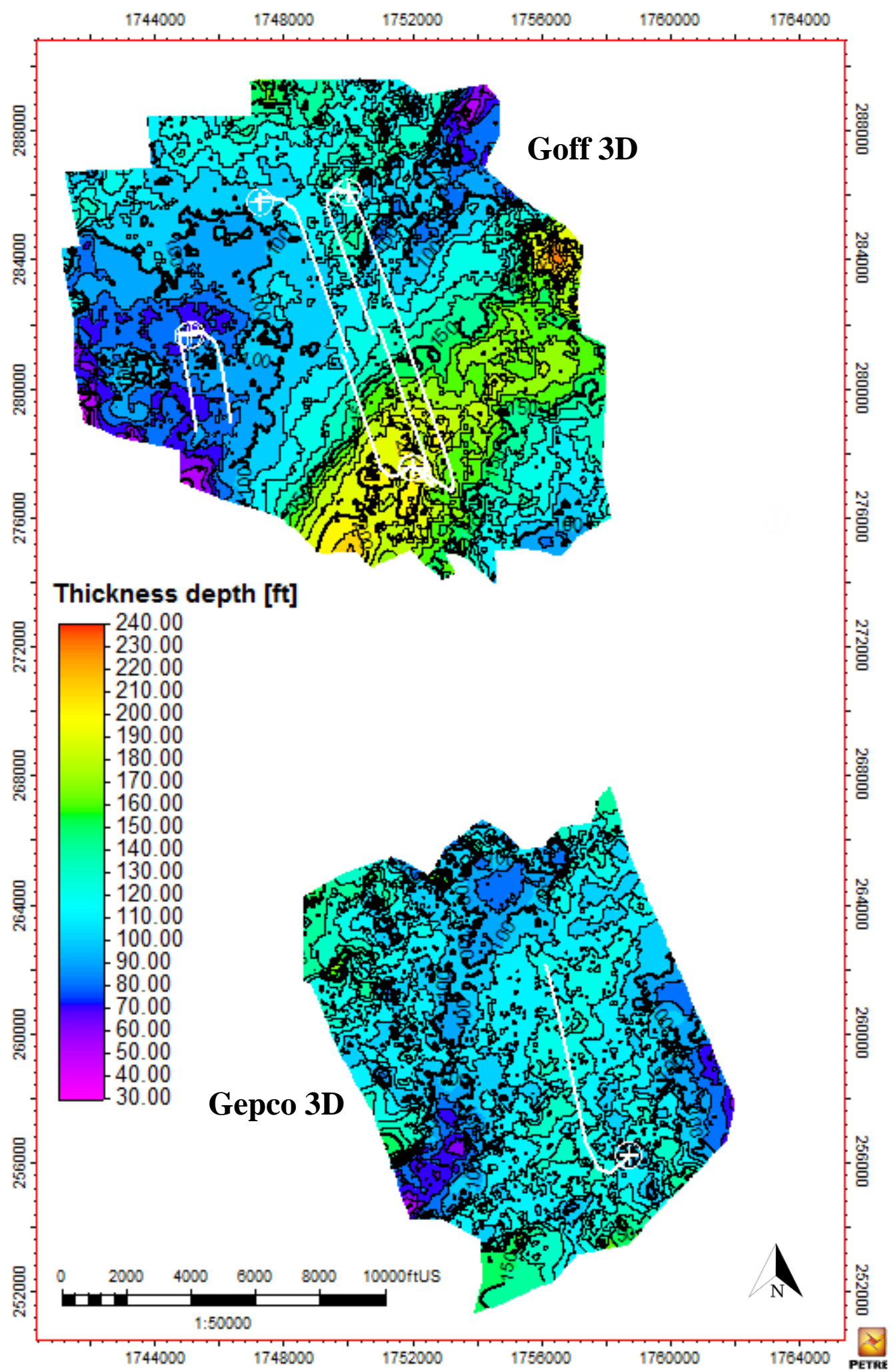

Figure 51: Marcellus shale thickness map. Marcellus shale wells within the 3D seismic are colored white. 


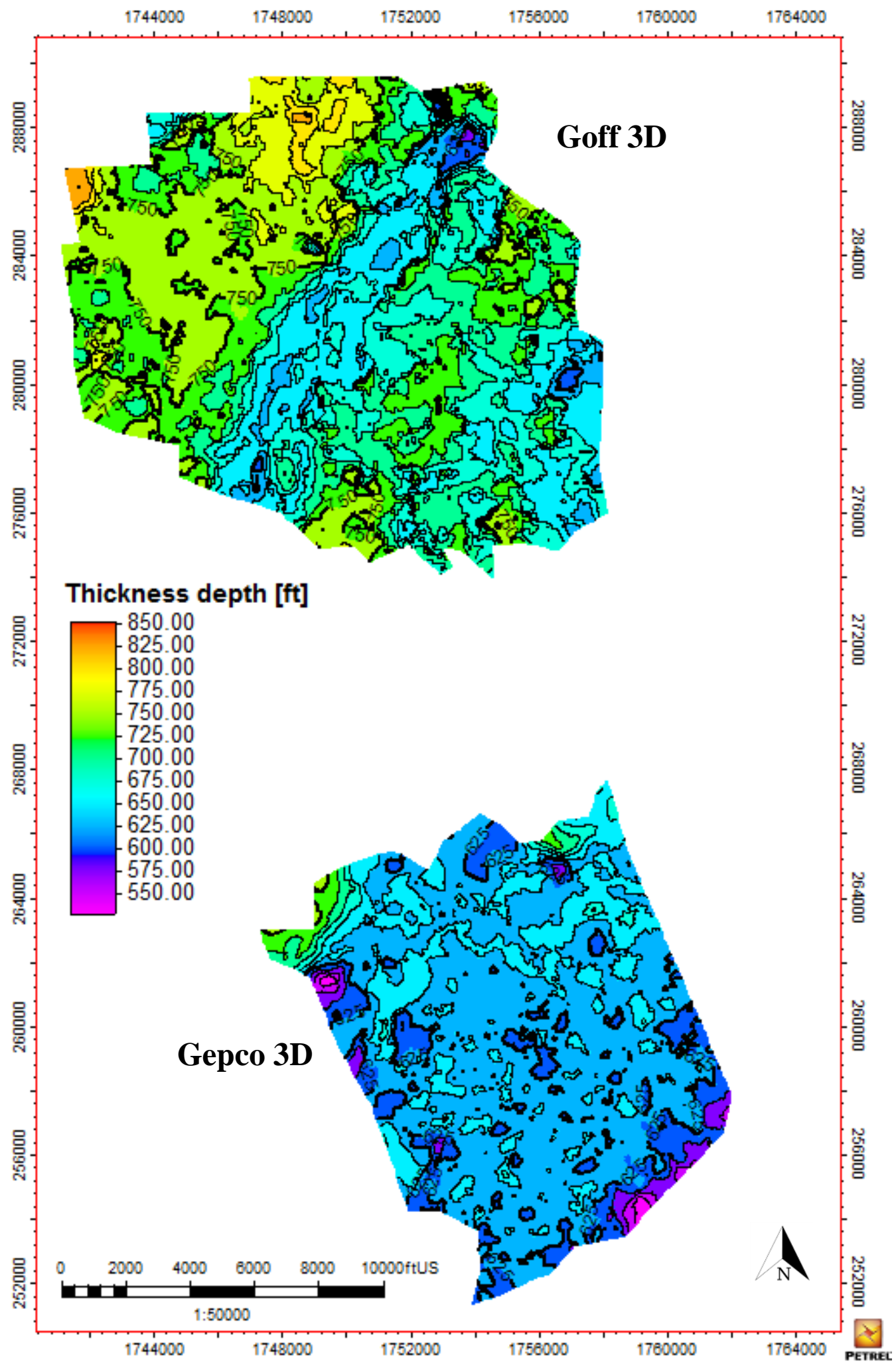

Figure 52: Trenton limestone thickness map. 
As noted above, these isochore maps also provide information concerning deformation history in the area. The Goff 3D is primarily used for this purpose because the Gepco 3D does not contain any large faults. Fault reactivation within the Goff 3D seismic dataset is constrained by analyzing thickness changes in seven major seismic stratigraphic packages in the region named by Kulander and Ryder (2005). From deep to shallow the seven stratigraphic packages assessed are: the Beekmantown Group, Trenton Limestone, Reedsville Shale, Juanita Formation, Salina Group, Hamilton Group and the Elk Group (Figure 53). The seismic stratigraphic packages are created by picking a top and base horizon (Table 5). The horizons used to create the thickness maps are referenced from Figure 53 (Kulander and Ryder, 2005). A velocity model was created to convert the horizons to depth and analyze thickness changes in feet. The average velocities used for the velocity model are summarized in Table 5. The deepest velocities were obtained from the nearby Burley well. The location of the Burley well is marked in Figure 33 Section 4.2 Horizon Picking for reference.

\begin{tabular}{|l|l|l|}
\hline Thickness Map & $\begin{array}{l}\text { Top and Base } \\
\text { Horizon Name }\end{array}$ & $\begin{array}{l}\text { Average Velocity } \\
\text { from Surface } \\
\text { (ft/sec) }\end{array}$ \\
\hline Elk Group & Java & 13695.33 \\
\hline Hamilton Group & Tully & 13733.26 \\
\hline Salina Group & Salina & 14064.70 \\
\hline Juanita & Tuscarora & 14628.92 \\
\hline Reedsville & Reedsville & 14719.94 \\
\hline Trenton & Trenton & 14632.69 \\
\hline Beekmantown & Beekmantown & 14902.85 \\
\hline & Copper Ridge & 15571.06 \\
\hline
\end{tabular}

Table 5: Average velocity used to convert two-way time seismic structure maps into the depth domain in order to create thickness maps in feet. 


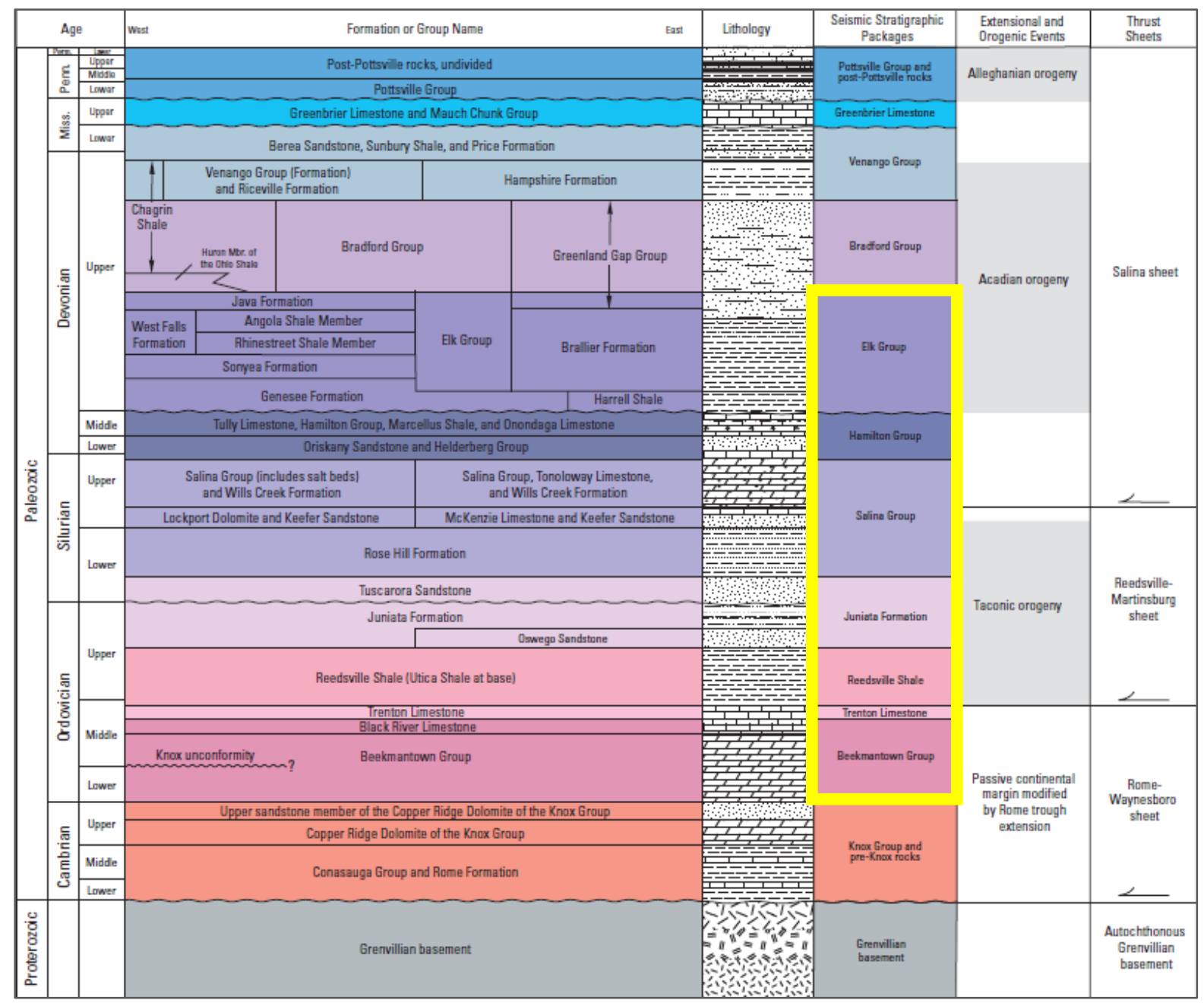

Figure 53: Modified from Kulander and Ryder (2005). Yellow rectangle indicates the seven seismic stratigraphic packages analyzed in this study for the Goff 3D seismic dataset. 
The Beekmantown Group is the deepest seismic stratigraphic package analyzed in this study (Figure 54). The deeper Knox Group and pre Knox rocks are not analyzed because of difficulties picking the top of the basement seismic reflection event and velocity modeling through to the basement rock. The Beekmantown Group thickness map (Figure 54) shows a distinct division at the location of the northeast tending basement fault. This fault separates the Goff 3D into two blocks: a northwest block and a southeast block. During the Lower and Middle Ordovician the Beekmantown Group was deposited in a passive continental margin. Evidence for reactivation is observed by the northwestern Goff 3D block thinning and the southeastern Goff 3D block thickening (Figure 54). The northwestern block is dropping down into the Rome trough and the southeastern block is moving up during Beekmantown Group deposition (Figure 54).

The next seismic stratigraphic package is the Trenton limestone (Figure 55). The Trenton limestone marks the end stages of the passive continental margin deposition and onset of the Taconic orogeny during the end of Trenton deposition. The Trenton limestone thickness maps shows the first evidence of inversion on the reactivated basement fault (Figure 55). This is depicted by the northwestern Goff 3D block thickening and the southeastern Goff 3D block thinning (Figure 55). This is the opposite of the Beekmantown Group thickness map trends. The northwestern block is moving up and the southeastern block is moving down.

The following seismic stratigraphic package is the Reedsville shale (Figure 56). During the Middle and Upper Ordovician the Reedsville shale was deposited at the beginning of the Taconic orogeny. The thickness ranges from 740 feet to 960 feet thick and there is a separation between the two blocks of the Goff 3D seismic. The northwestern block is slightly thinner on 
average than the southeastern block. This indicates another inversion of block movement since the deposition of the Trenton limestone. During the deposition of the Reedsville shale the northwestern block began to once again move up relative to the southeastern block. The inversion and movement observed during Reedsville shale deposition is minor.

The next seismic stratigraphic package is the Juniata Group (Figure 57). The Juanita Group was deposited in the Upper Ordovician and Lower Silurian during the middle of the Taconic orogeny. The Juanita Group has an average thickness of 750 feet and there is no evidence of fault movement. The two blocks of the Goff 3D are not readily observed in the Juanita Group thickness map.

The following seismic stratigraphic package is the Salina Group (Figure 58). The Salina Group was deposited during the Silurian at the final stages of the Taconic orogeny. The Salina Group thickness map shows evidence for reactivation of the fault with a thickening trend between the two fault blocks in the Goff 3D.

The next seismic stratigraphic package is the Hamilton Group (Figure 59). The Hamilton Group was deposited in the Lower and Middle Devonian. The Hamilton Group thickness map shows thinning on the northwestern block and thickening on the southeastern block. The northwestern block, with an average thickness of 1440 feet, is relatively thinner than the southeastern block that has an average thickness of 1500 feet. The block movement is minor and the direction is the same as during the Middle Ordovician during deposition of the Reedsville shale; no inversion is observed. 
The final, most shallow, seismic stratigraphic package assessed in this study is the Elk Group (Figure 60). The Elk Group was deposited in the Upper Devonian during the early stages of the Acadian orogeny. Elk Group thickness ranges from 440 feet to 480 feet and is variable throughout the Goff 3D seismic; no fault movement from the two block is observed.

The seven thickness maps are juxtaposed in Figure 61. The location of the reactivated fault and relative movement of the two fault blocks becomes more evident when the maps are viewed simultaneously. In the Lower Ordovician the northwestern fault block moves down and is inverted to an upward movement in the Middle Ordovician. Another inversion to cause this block to move back down occurs in the Upper Ordovician and this thinning although minor remains consistent through to the Upper Devonian. A vertical seismic slice and seismic line drawing also help depict the thickness changes in the major seismic stratigraphic packages (Figure 62). An analysis of percent thickness change from the northwestern block compared to the southeastern fault block was completed to summarize movement on the reactivated fault (Figure 63). Three periods of fault reactivation were interpreted. 


\section{Goff 3D}

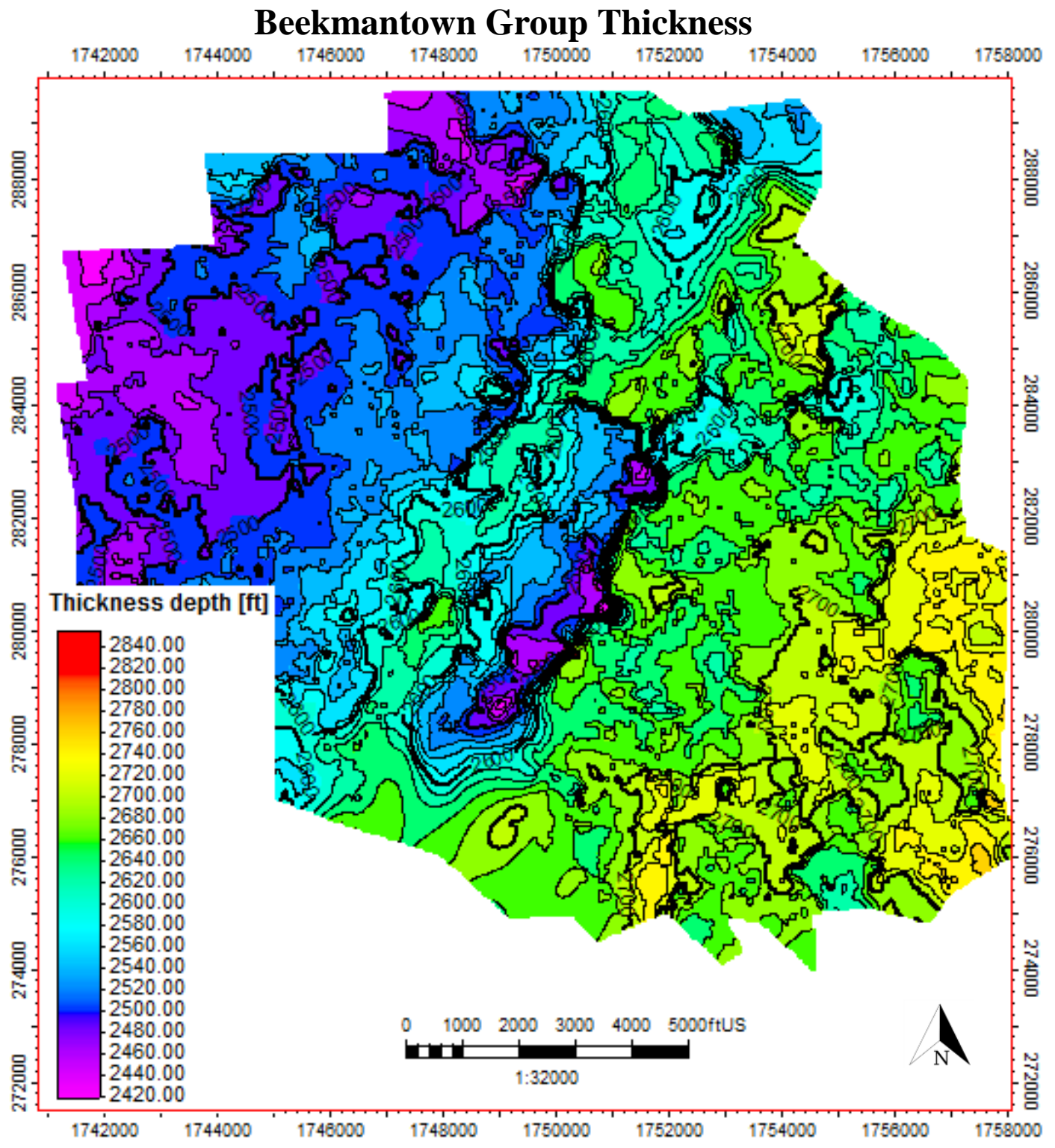

Figure 54: Thickness map from the top of the Black River limestone to the top of the Copper Ridge dolomite to depict the thickness of the Beekmantown Group seismic stratigraphic package. 


\section{Goff 3D}

\section{Trenton Limestone Thickness}

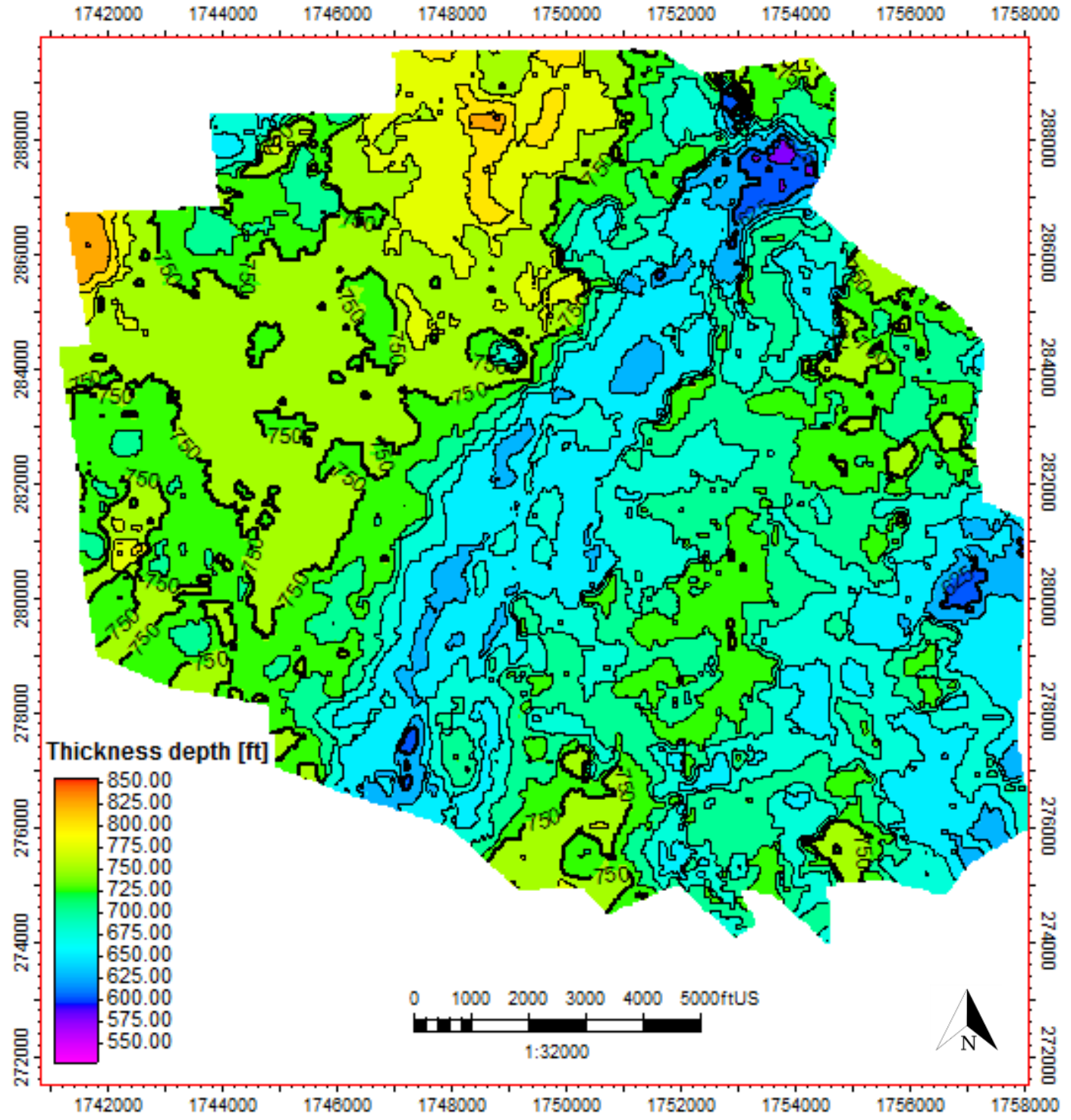

Figure 55: Thickness map from the top of the Trenton limestone to the top of the Black River limestone to depict the thickness of the Trenton limestone seismic stratigraphic package. 


\section{Goff 3D}

\section{Reedsville Shale Thickness}

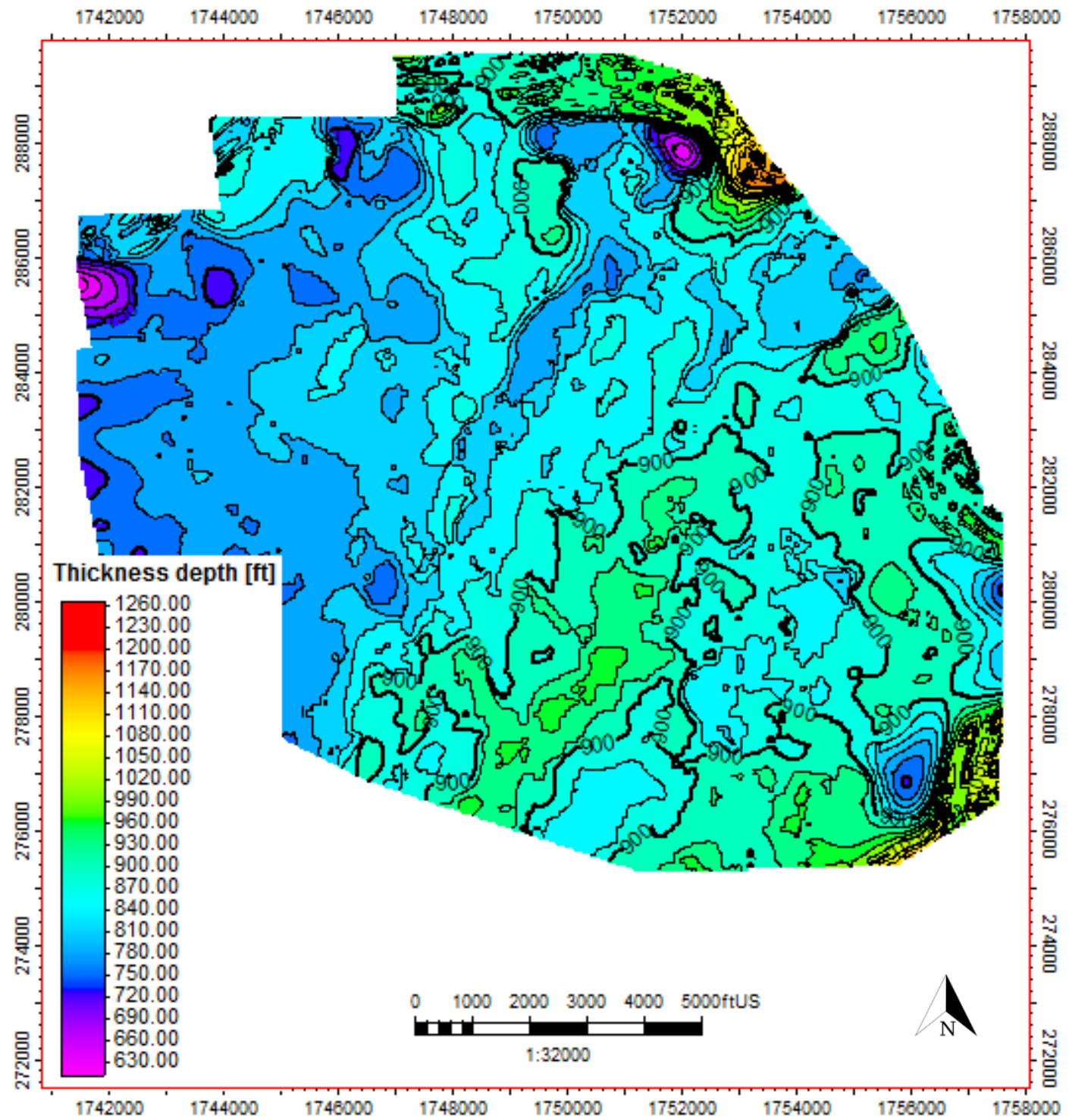

Figure 56: Thickness map from the top of the Reedsville shale to the top of the Trenton limestone to depict the thickness of the Reedsville shale seismic stratigraphic package. 


\section{Goff 3D}

\section{Juanita Group Thickness}

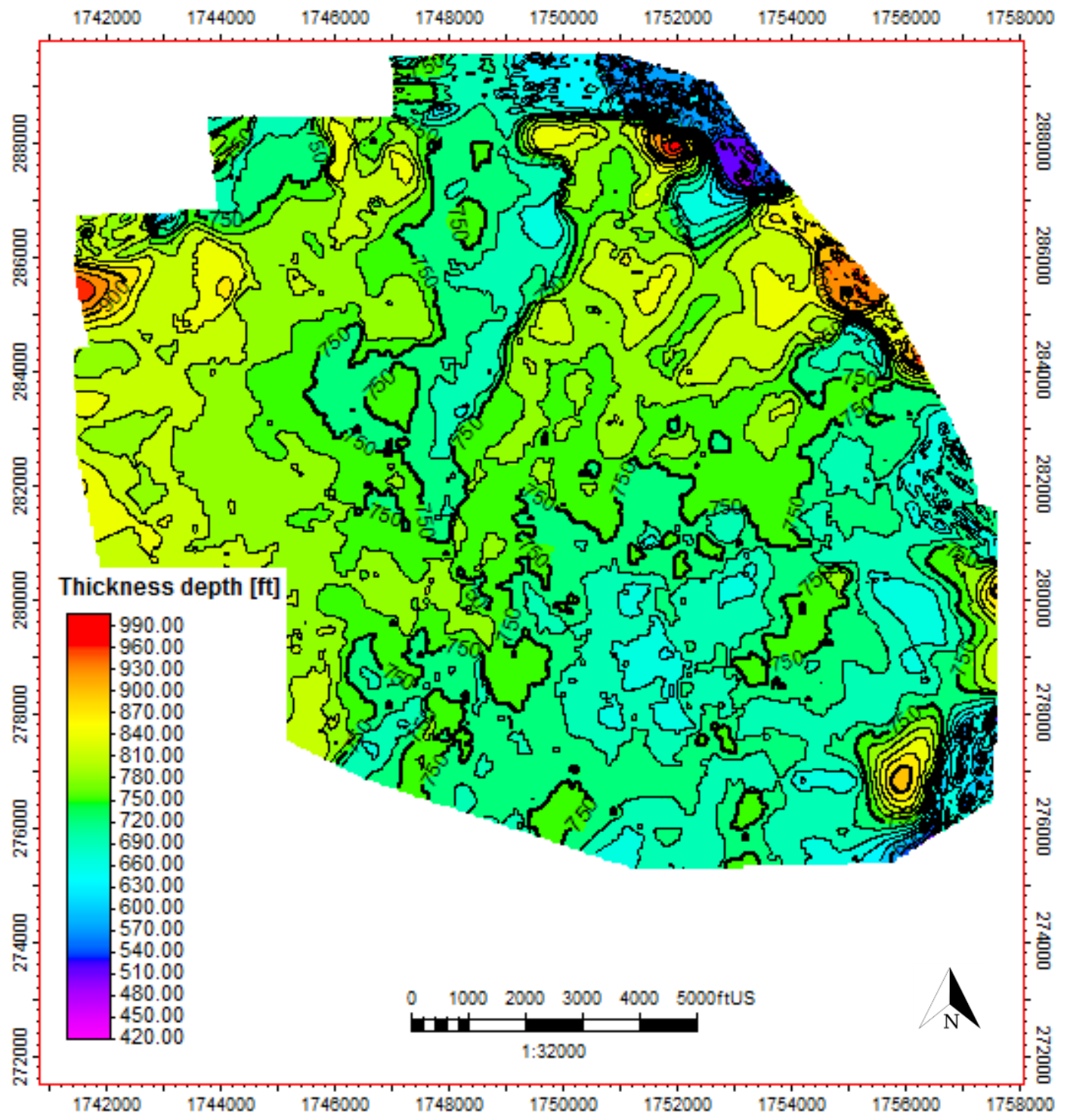

Figure 57: Thickness map from the top of the Tuscarora sandstone to the top of the Reedsville shale to depict the thickness of the Juanita Group seismic stratigraphic package. 


\section{Goff 3D}

\section{Salina Group Thickness}

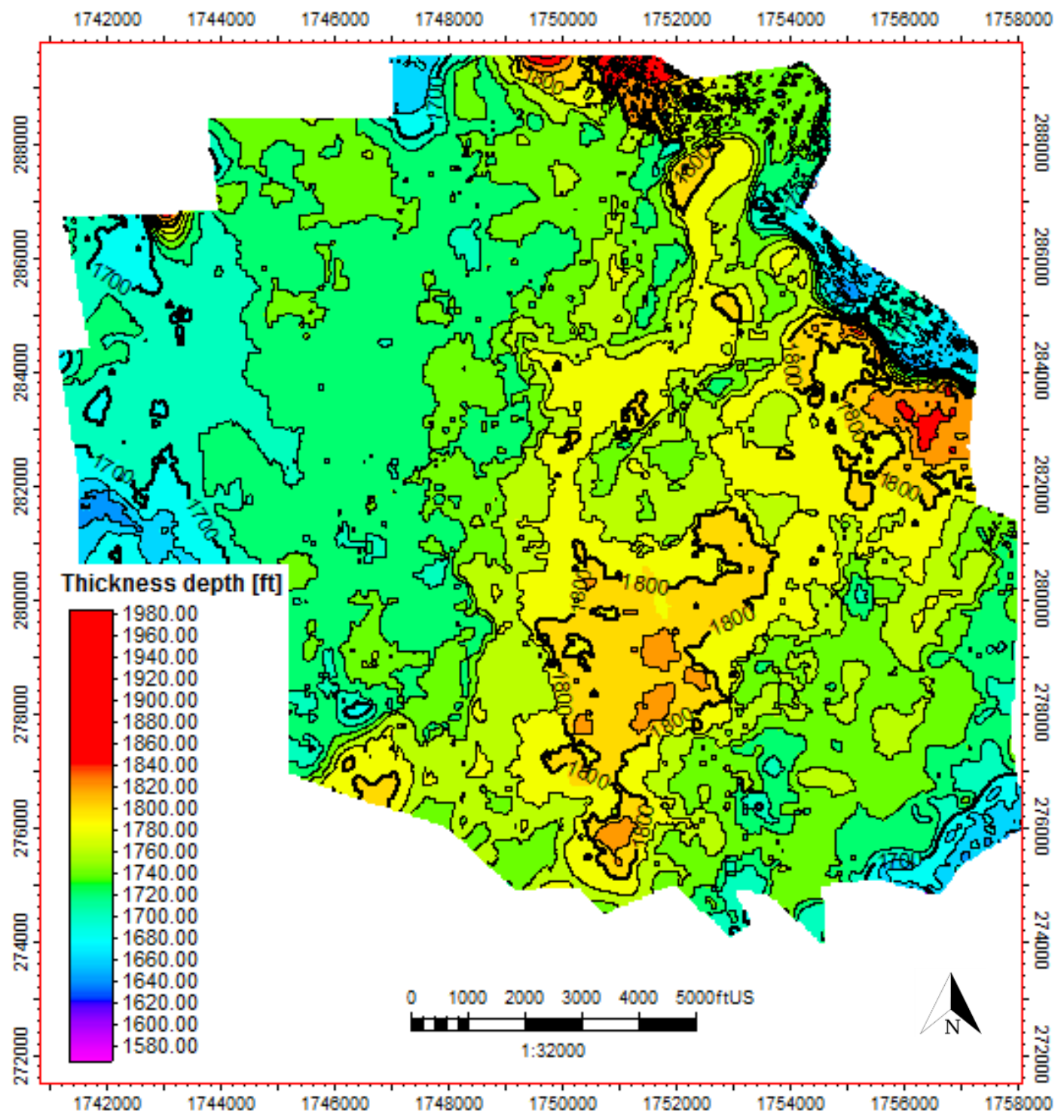

Figure 58: Thickness map from the top of the Salina Group to the top of the Tuscarora sandstone to depict the thickness of the Salina Group seismic stratigraphic package. 


\section{Goff 3D}

\section{Hamilton Group Thickness}

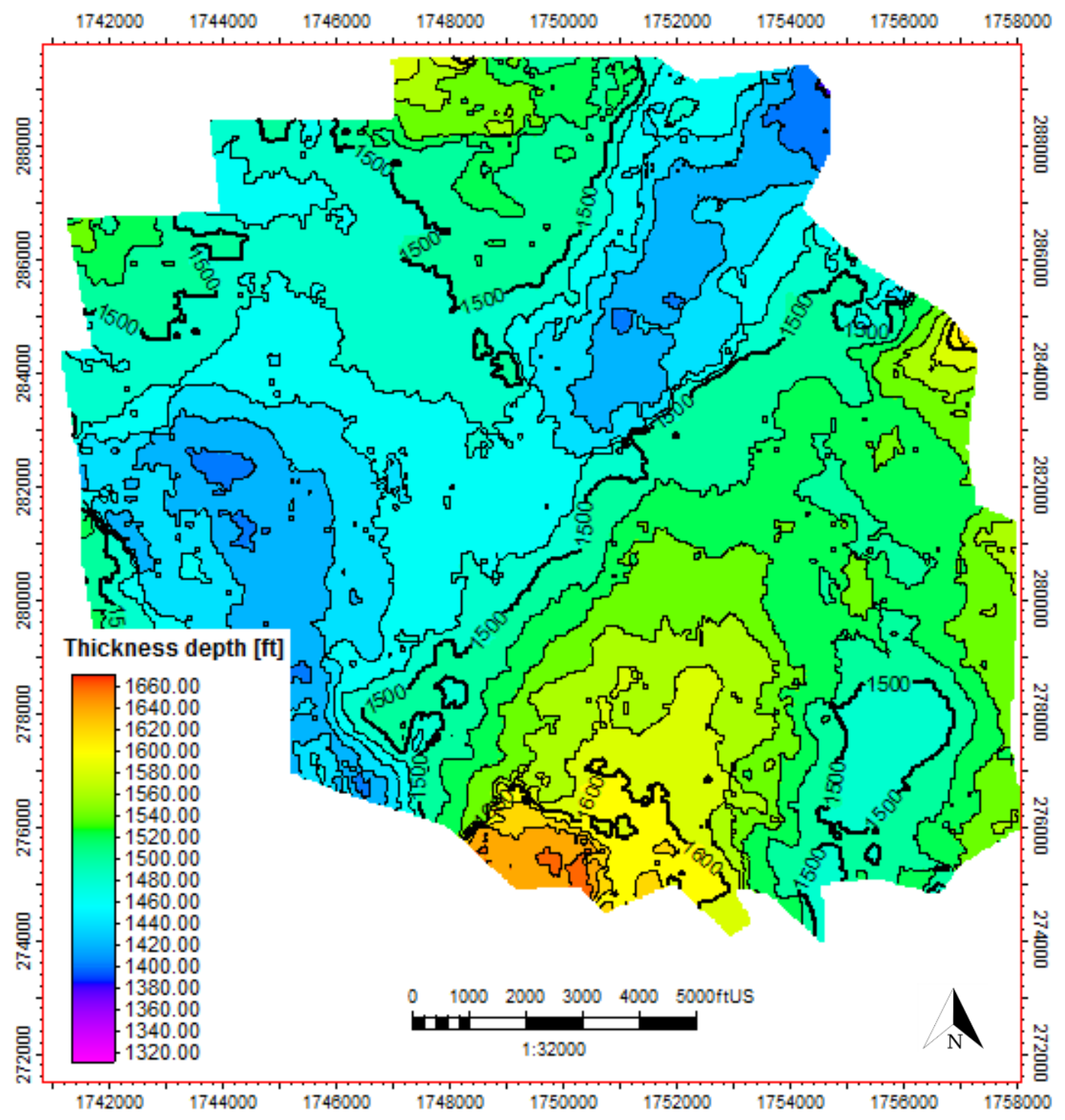

Figure 59: Thickness map from the top of the Tully limestone to the top of the Salina Group to depict the thickness of the Hamilton Group seismic stratigraphic package. 


\section{Goff 3D}

\section{Elk Group Thickness}

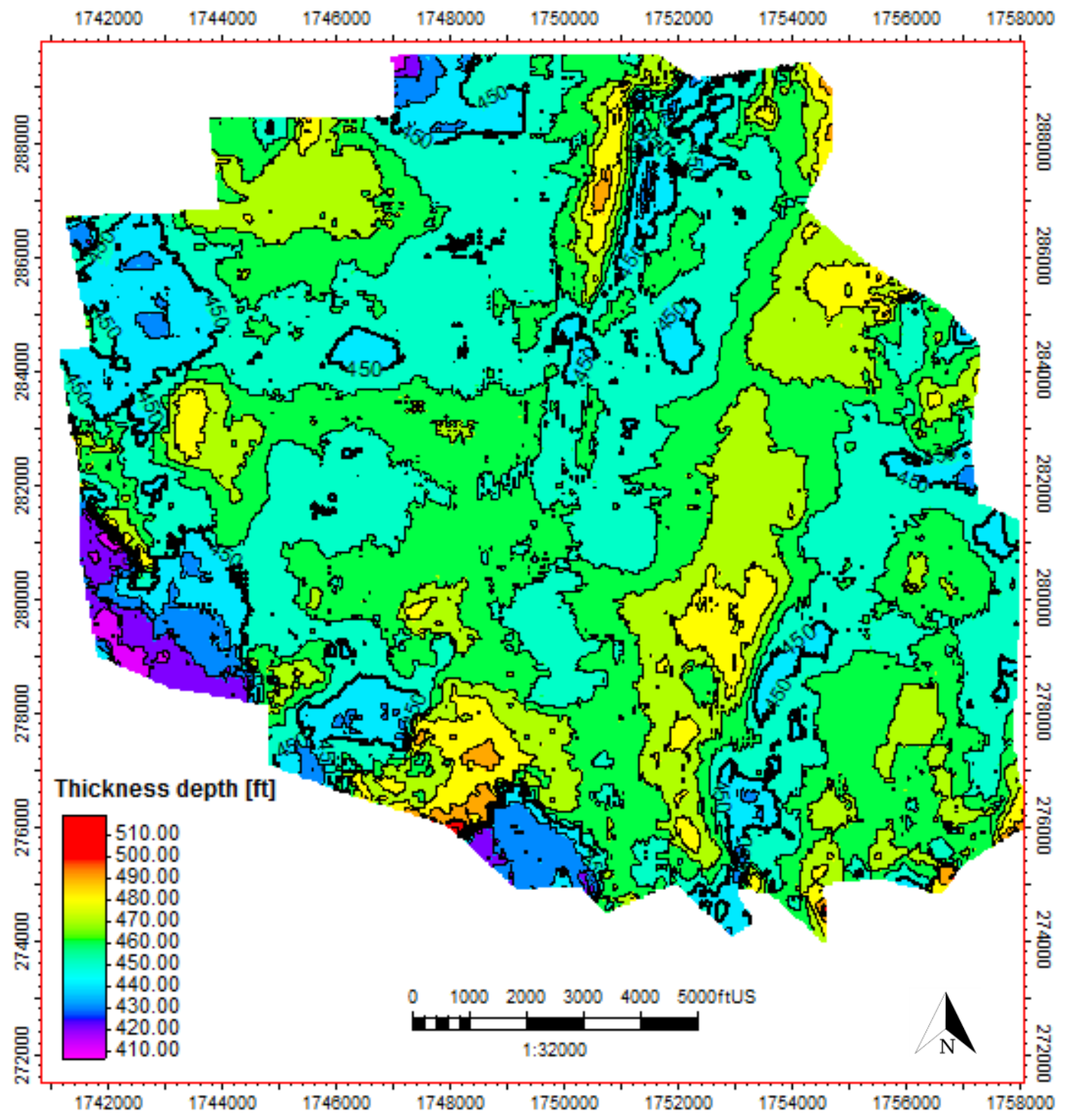

Figure 60: Thickness map from the top of the Java Formation to the top of the Tully limestone to depict the thickness of the Elk Group seismic stratigraphic package. 

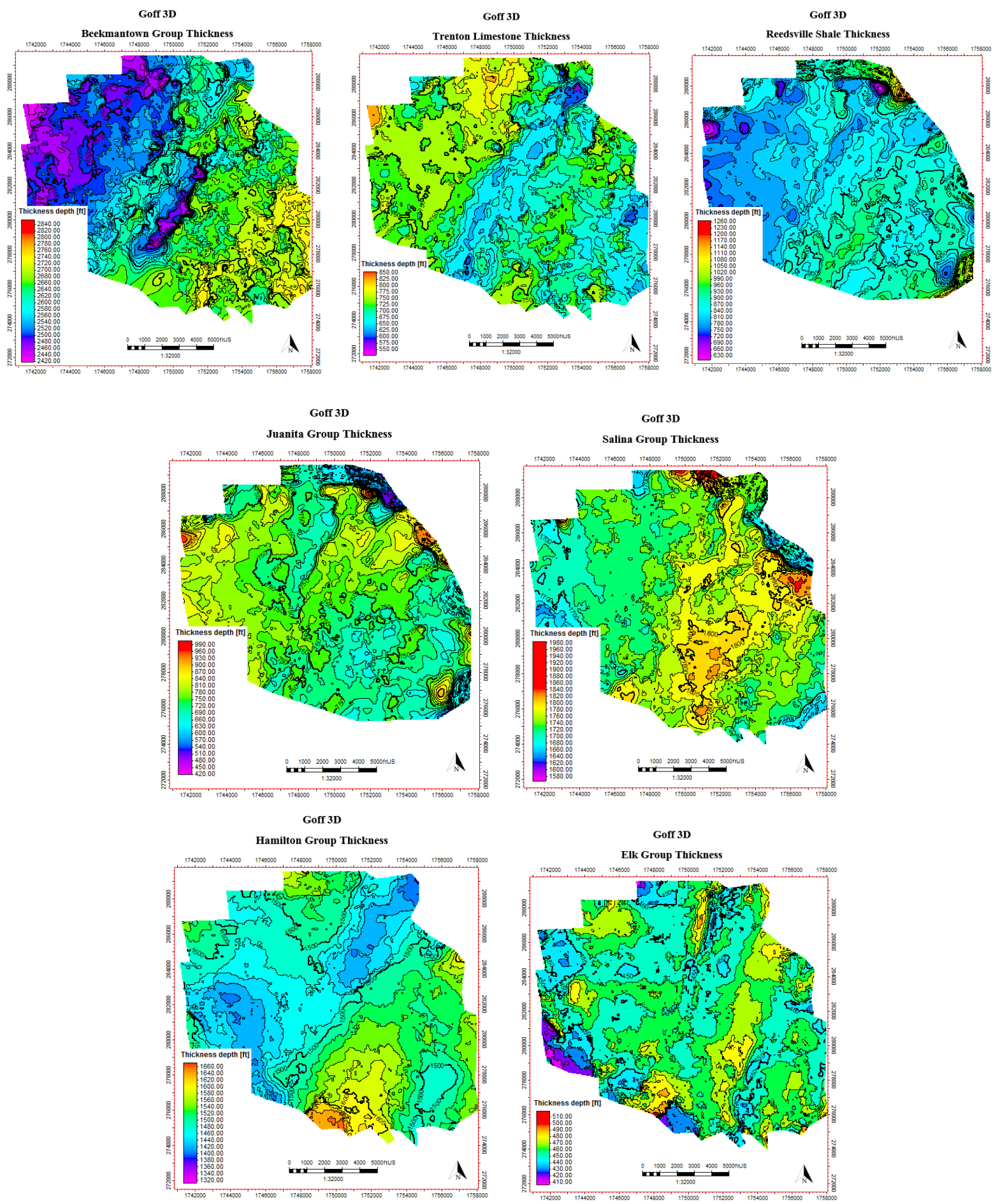

Figure 61: Thickness maps of the Goff 3D seismic stratigraphic packages in successive order to compare thickness changes throughout time. 

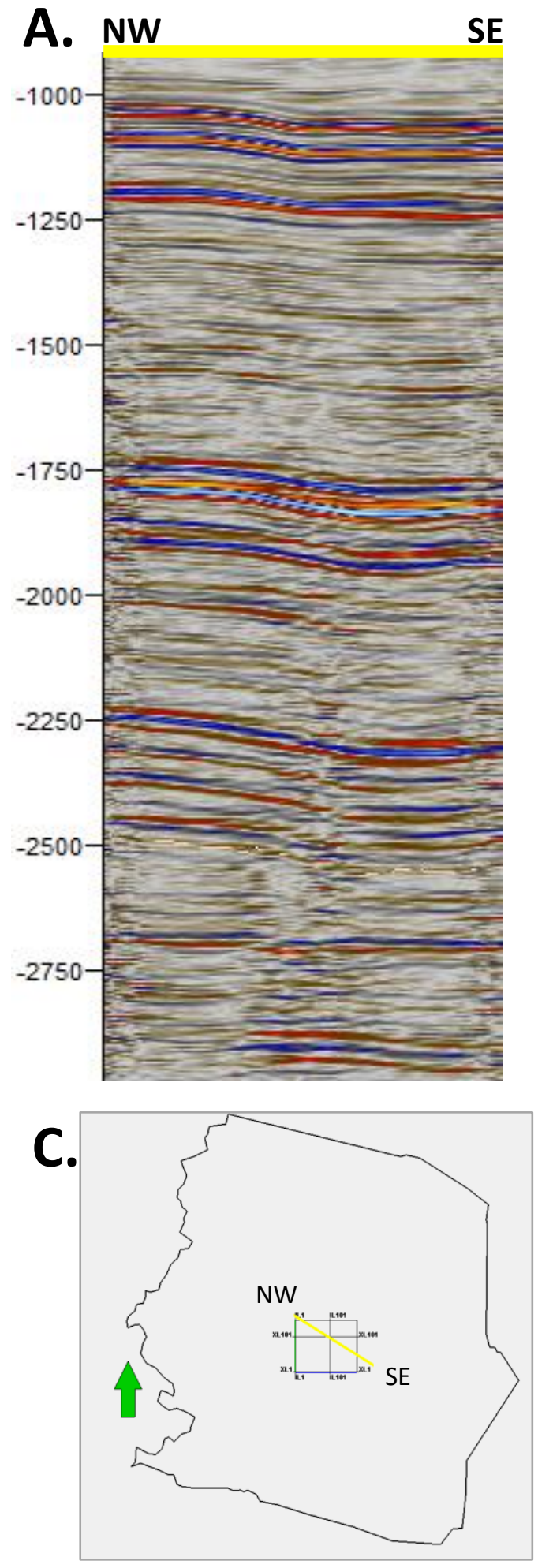

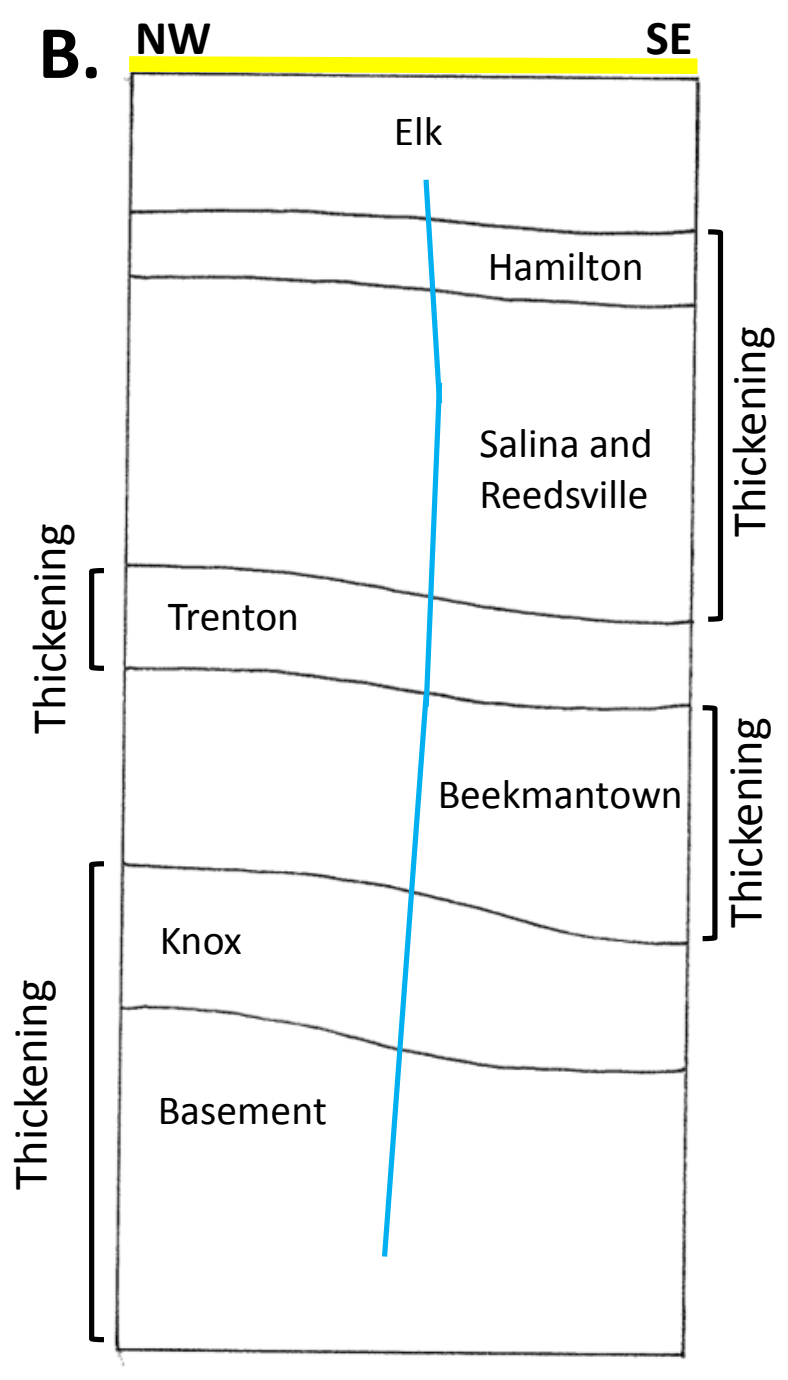

Figure 62: A: Arbitrary seismic line perpendicular to the fault. B: Seismic line drawing of the thickness changes of major seismic stratigraphic packages. C: Location of the seismic line in the Goff 3D seismic survey with an outline of Harrison county West Virginia. 


\section{Percent Thickness Change on NW Block}

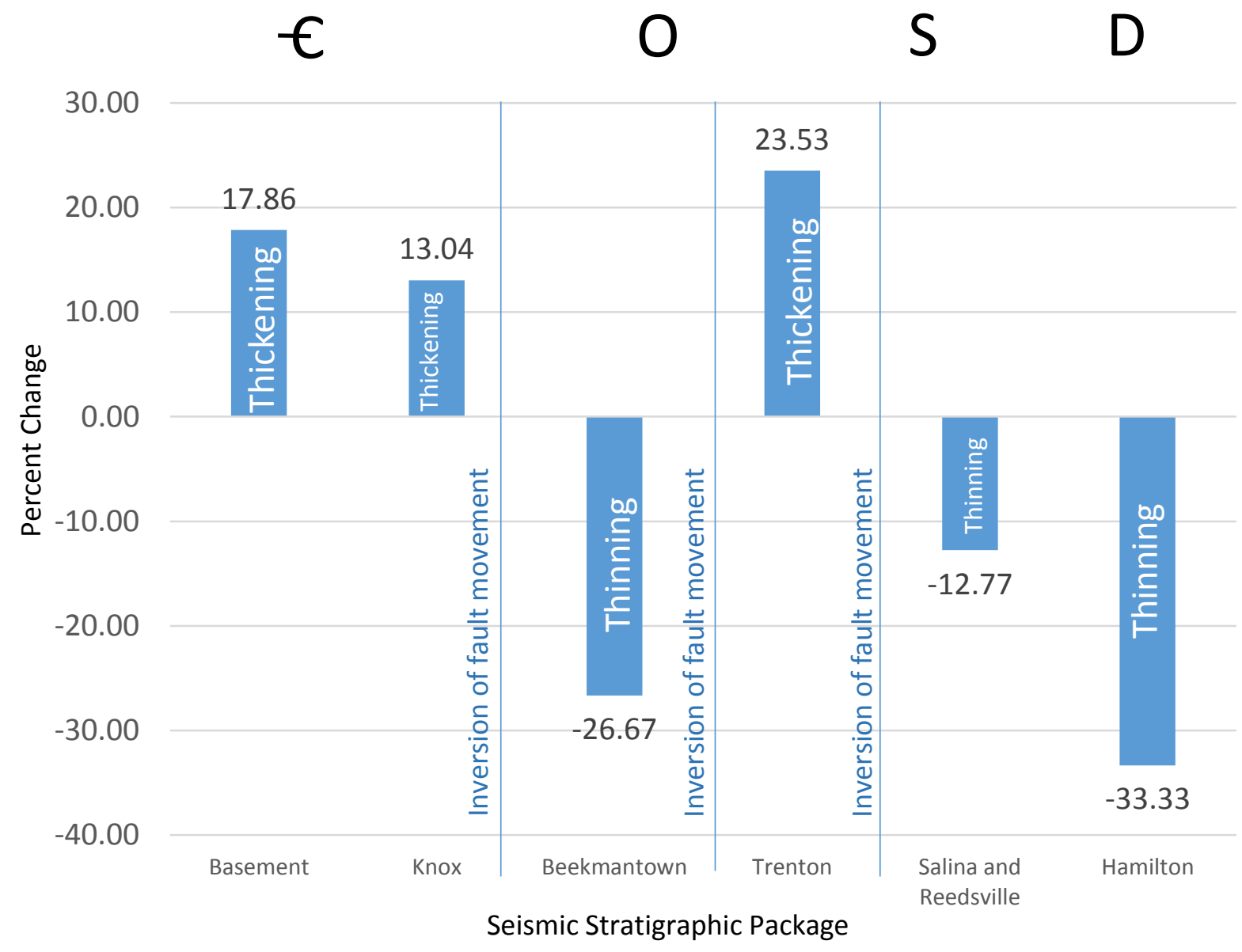

Figure 63: Thickness change over the northwest fault block reported as a percent change relative to thickness over the southeast fault block. 


\subsection{Natural Fracture Analysis}

Understanding the structural style and contemporary stress regime (Section 2.2.1) is important to hydrocarbon production. One implication of structural style in unconventional reservoirs is preexisting fractures that may aid in production by providing natural hydrocarbon migration pathways.

In the 1970's the United States Department of Energy funded the Eastern Gas Shales Project to develop technologies, such as hydraulic fracturing, that would advance the development of shale gas production in the Appalachian basin (Schrider and Wise, 1980). One conclusion from this project was that hydraulic fracturing alone was insufficient to achieve commercial shale gas production on vertical wells (Horton, 1982). However, results did indicate that whenever manual hydraulic fractures would intersect natural fractures a flow path could be generated (Soeder and Kappel, 2009). For this reason, understanding the distribution of natural fractures in low permeability hydrocarbon bearing rocks becomes increasingly important. The ability to map these preexisting fractures and understand their orientation and relationship to the contemporary stress field may aid in wellbore planning and lateral placement.

In the Appalachian basin several black shale units carry two regional joint sets named J1 and J2 (Engelder et al., 2009) (Figure 64). These joint sets formed as natural hydraulic fractures at peak burial depth during thermal maturation of organic matter (Engelder et al., 2009). The J1 set is parallel to the present day maximum horizontal stress. Horizontal drilling in Devonian black shales should occur perpendicular to present day maximum horizontal stress to maximize benefit of wellbore communication with both joint sets.

There is a change in joint orientation form New York to Kentucky and a lack of data in southwestern Pennsylvania and northern West Virginia. This study compiles information from 
four 3D seismic surveys which interpret seismic fracture zones within the Marcellus shale. The seismic surveys are located in southwestern Pennsylvania and northern West Virginia.

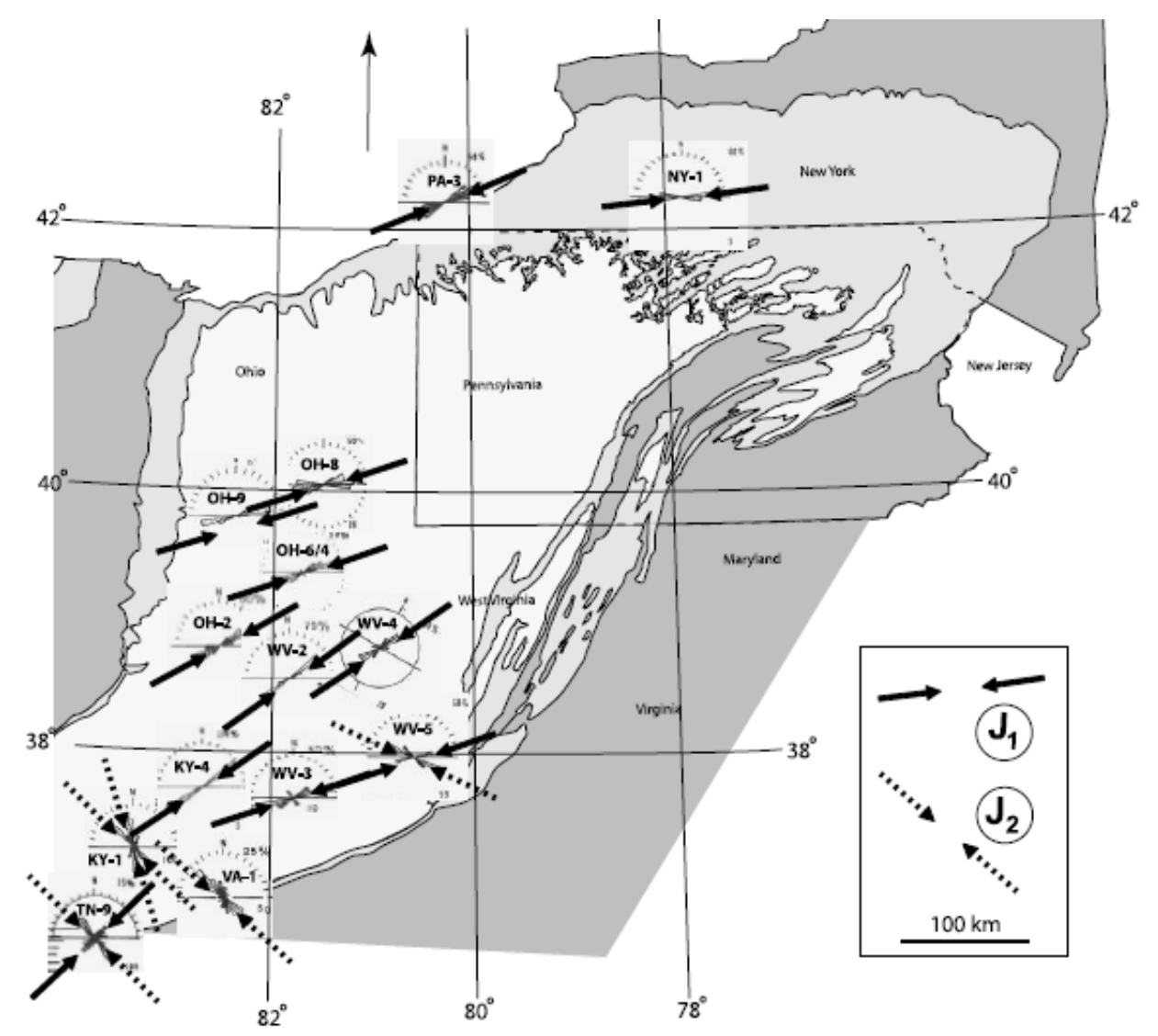

Figure 64: Plotted orientations of interpreted joints in the Huron shale. The Huron is one of the black shales in the Middle and Upper Devonian section of the Appalachian basin that carries regional joint sets and may provide insight into the fracturing trends of the Marcellus shale. These orientations are observed from cores (Engelder et al., 2009). 


\subsubsection{Three Dimensional Seismic Discontinuities}

To interpret small faults and fracture zones near the Marcellus shale the three dimensional seismic data was enhanced using a post-stack processing workflow similar to that of Wilson et al. (2016). The workflow included t*attenuation (Najmuddin, 2001) and dip deviation processing followed by extracting the seismic discontinuities with Ant Tracking (Pederson et al., 2002 and 2003).

Ant Tracking is used to interpret discontinuities in 3D seismic volumes. The process is called Ant Tracking because real ants use swarm intelligence with pheromone trails to signal colony members of food and nest locations to use the shortest and quickest path possible (Cox, 2007). The main steps are 1) enhance the spatial discontinuity in the seismic data, 2) improve fault attributes by suppressing noise, and 3) create subsystems (to) ease the extraction of fault surfaces (Pederson et al., 2002). In the first step the Ant Tracking uses swarm intelligence to track approved signals and terminate on unapproved signals. The agents are coded to detect what parameters are set for fault tracking and leave an "electronic pheromone" trail. The agents will terminate if it is not an approved code for a fault and leave signals where there are desired fault features. After Ant Tracking the interpreter must decide which attributes to keep and what they mean. Processes for Ant Tracking interpretation include multi-level analyses where the interpreter can keep, separate or dismiss faults picked by the Ant Tracking (Pederson et al., 2003).

Ant Tracks were extracted onto both the Marcellus shale and Onondaga limestone structural surfaces in both the Goff 3D and Gepco 3D seismic datasets. Uninterrupted and interpreted seismic discontinuities on each of the surfaces are shown (Figures 65, 66, 67 and 68). 


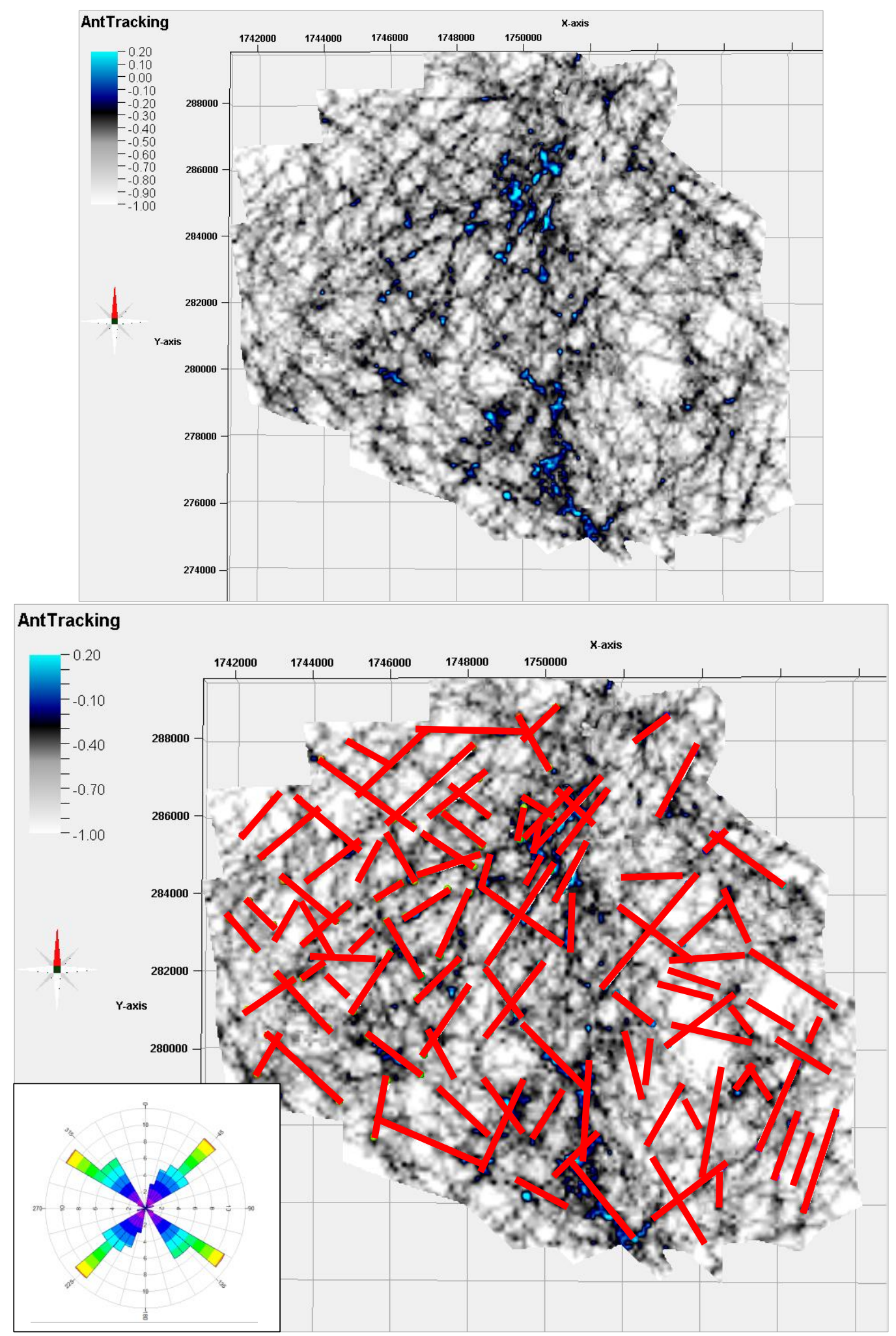

Figure 65: Top: Goff 3D Marcellus shale surface map with extracted Ant Tracking attribute, not interpreted. Bottom: The same Marcellus shale horizon with interpreted seismic discontinuities. 


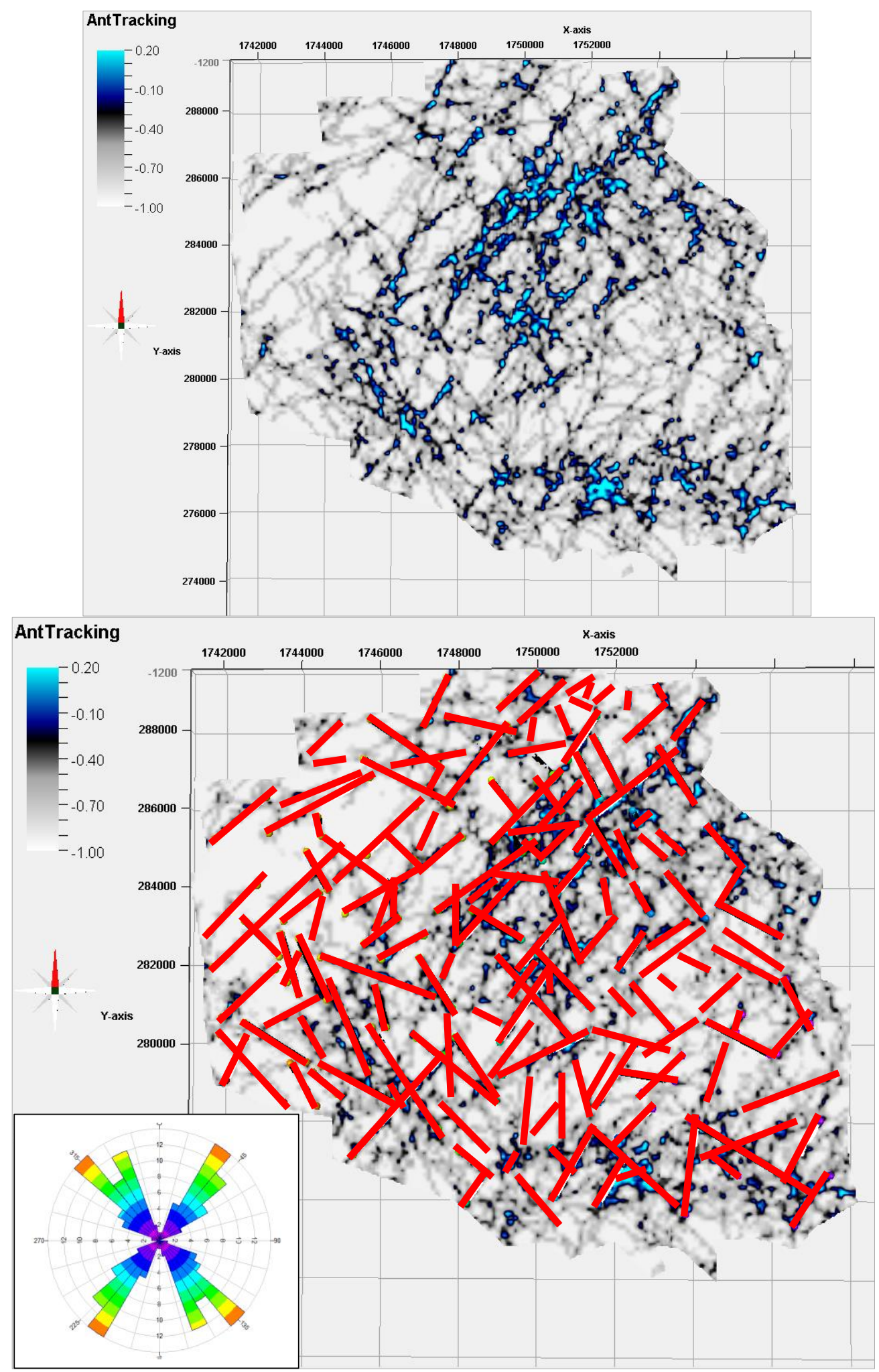

Figure 66: Top: Goff 3D Onondaga limestone surface map with extracted Ant Tracking attribute, not interpreted. Bottom: The same Onondaga limestone horizon with interpreted seismic discontinuities. 

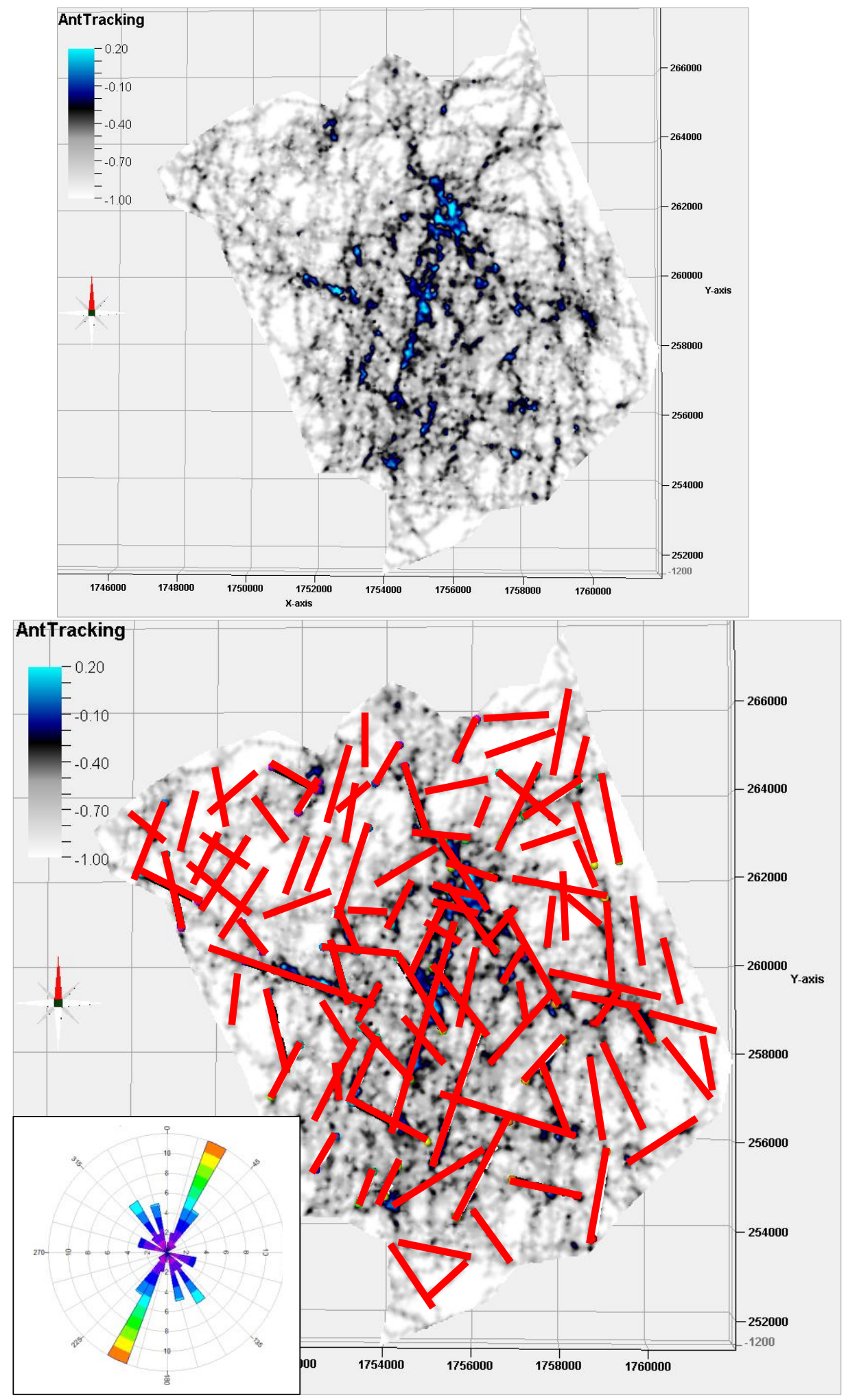

Figure 67: Top: Gepco 3D Marcellus shale surface map with extracted Ant Tracking attribute, not interpreted. Bottom: The same Marcellus shale horizon with interpreted seismic discontinuities. 

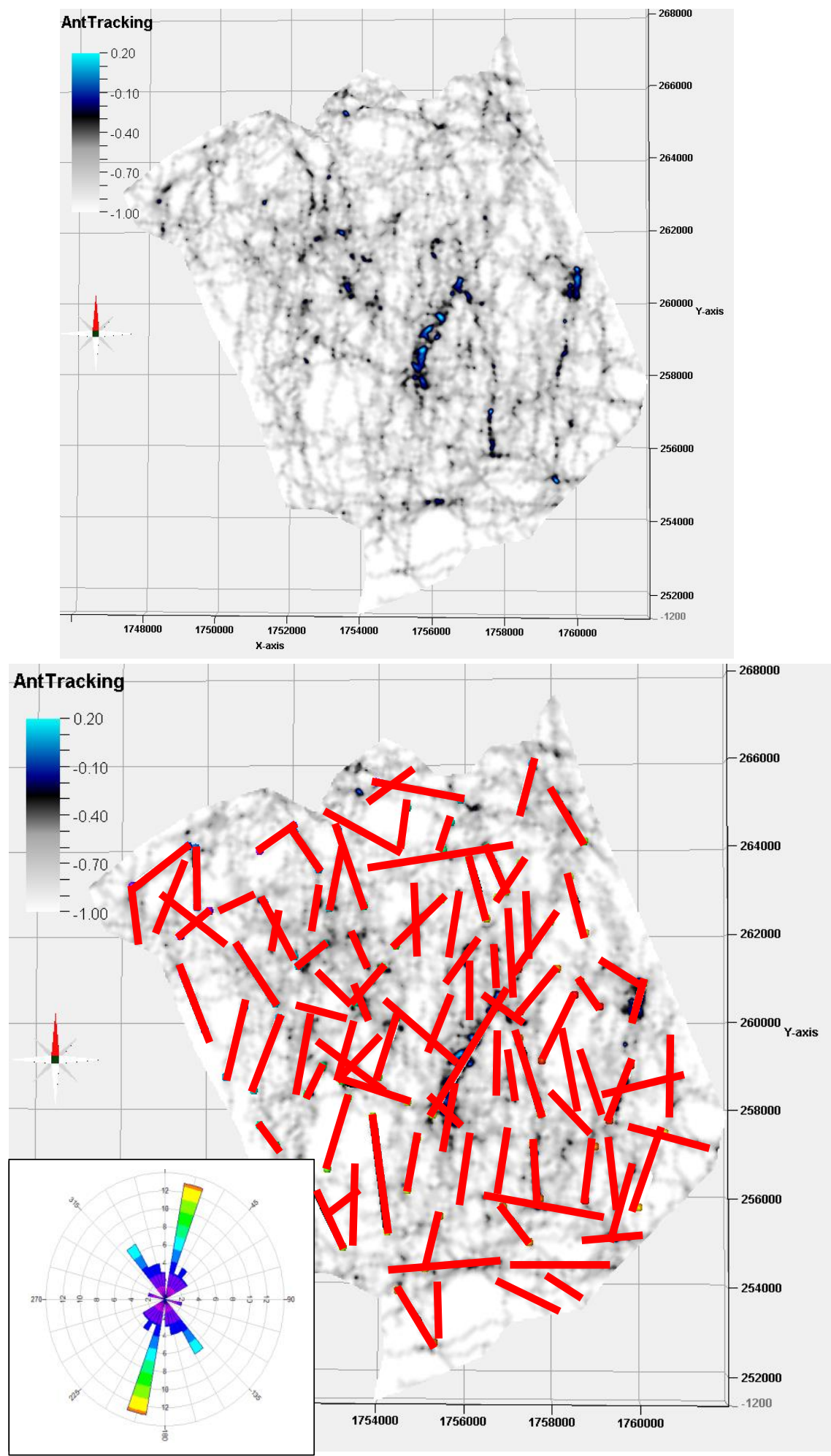

Figure 68: Top: Gepco 3D Onondaga limestone surface map with extracted Ant Tracking attribute, not interpreted. Bottom: The same Onondaga limestone horizon with interpreted seismic discontinuities. 
The seismic discontinuities from each seismic survey for the Marcellus shale and Onondaga limestone surfaces are plotted in rose diagrams (Figure 69). Within the Goff 3D two prominent discontinuity trends were interpreted in the Marcellus shale surface: N40E and N48W. Similar discontinuity trends are interpreted in the Goff 3D Onondaga limestone surface: N40E and N41W. Within the Gepco 3D one prominent seismic discontinuity trend was interpreted in the Marcellus shale surface oriented at N26E. A northwest trend of N30W was also interpreted in the Marcellus shale of the Gepco 3D but the frequency of this orientation was less than the northwest trends in the Goff 3D. Similar trends are observed in the Gepco 3D Onondaga surface: N15E and N33W. 


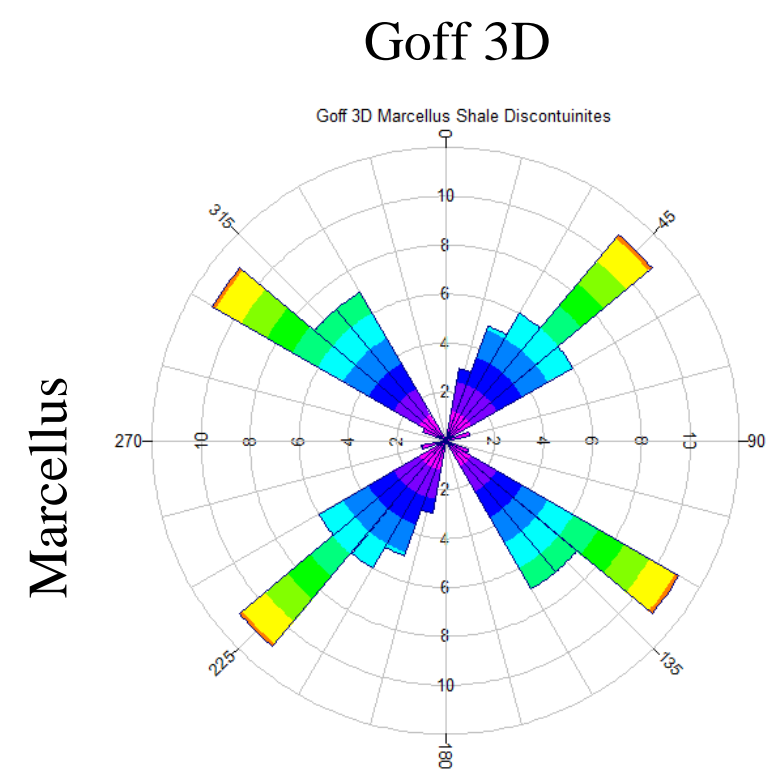

\section{Gepco 3D}
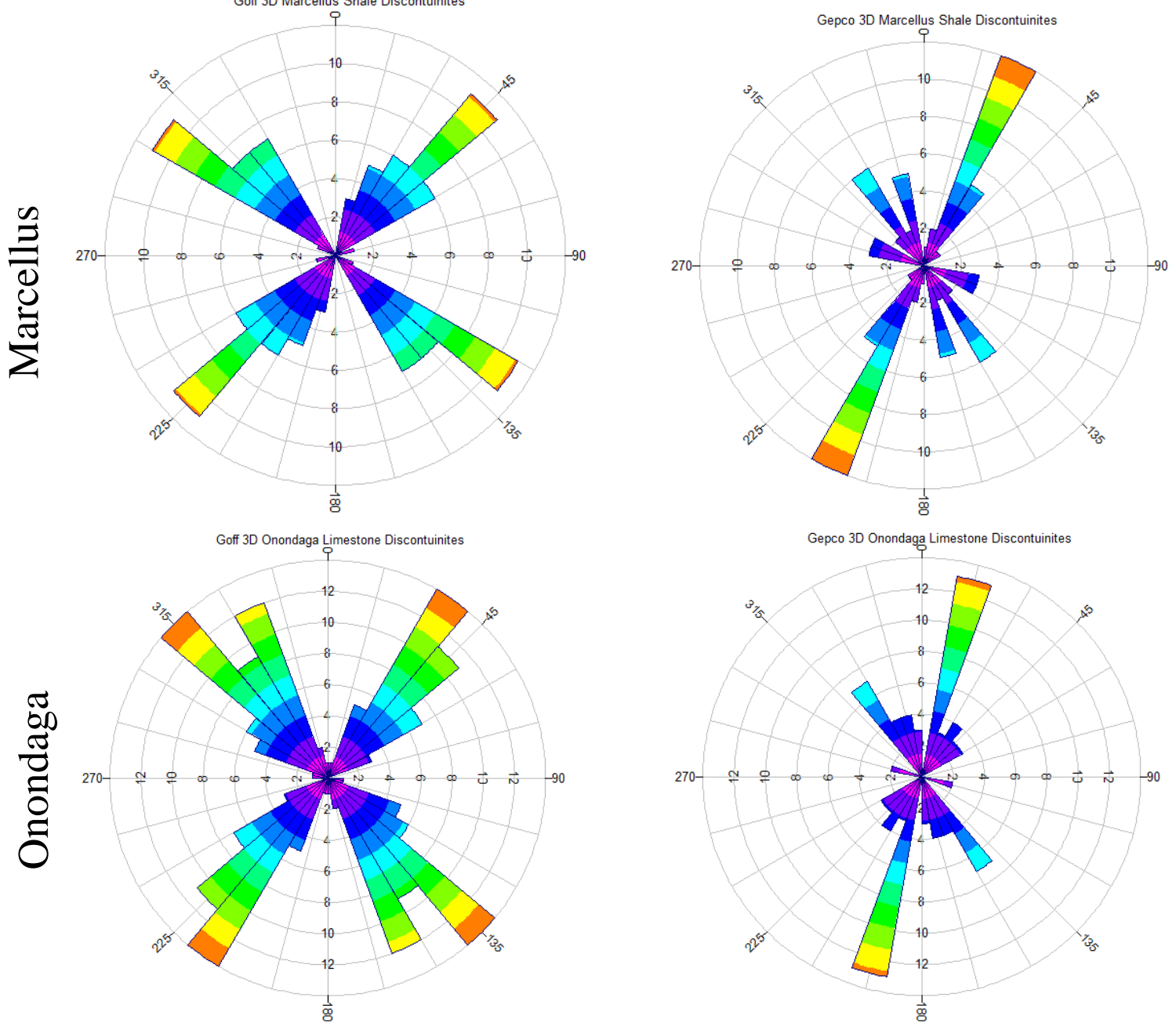

Figure 69: Rose diagrams of Marcellus shale and Onondaga limestone surfaces seismic discontinuities frequency and orientation for the Goff 3D and the Gepco $3 \mathrm{D}$. 
Two similar 3D seismic discontinuity studies were completed in the Appalachian basin. A study in Taylor County West Virginia found orientation of major Marcellus shale seismic discontinuities to be N52E and N45W (Zhu, 2013). These averages were derived from seismic discontinuity picks from an Ant Tracking seismic volume over three two-way travel time slices: 1174ms, -1184ms, -1194. Zhu interpreted these discontinuities as the $\mathrm{J} 1$ and $\mathrm{J} 2$ joint sets in the Marcellus shale (Zhu, 2013, p. 63). Zhu also states that the maximum horizontal stress is trending east-west (from extrapolation of the World Stress Map) but suggests a horizontal well orientation of N38W implying that maximum horizontal stress is N52E based off of the discontinuity data (Zhu, 2013, p.62). A study in Greene County Pennsylvania found major Marcellus shale seismic discontinuities oriented at an average of N43E to N41W (Hart, 2014). The orientations are derived from seismic discontinuity picks from an Ant Tracking seismic volume from three seismic horizons: the top of the Marcellus shale, the top of the lower Marcellus shale, and the top of the Onondaga limestone. The orientations change with depth and the northeast discontinuities become more frequent in the Onondaga limestone below the Marcellus shale.

Marcellus shale formation image log studies have also been completed in the surrounding areas to provide a more comprehensive understanding of the maximum contemporary stress field (Roberts, 2013 and Wilson, 2015). Orientations of partially open and open fractures as interpreted by Schlumberger from a formation imaging log in a Marcellus shale well in Clearfield County Pennsylvania had average orientations for open and partially fractures in the Marcellus shale interval are N40E and N42W (Roberts, 2013). The inferred maximum horizontal stress is N48E (Roberts, 2013). Orientations of induced fractures and borehole breakout were interpreted by a service company for the Marcellus shale zone in Monongalia County West 
Virginia. Analysis of the data (Wilson, 2016, written communication) indicates that the orientation of the maximum horizontal stress inferred from induced fractures is $\sim \mathrm{N} 57 \mathrm{E}$ and that from breakouts, N64E.

Summarizing the World Stress Map data with present day research provides a more comprehensive insight into the contemporary stress field of the surrounding study area (Table 6). Extracted seismic discontinuities interpreted as small faults and preexisting fracture zones are summarized and reported for the Marcellus shale (Table 7). The stress data and discontinuity data are plotted together on a map to spatially analyze the orientation of these data (Figure 70). Analyzing the seismic discontinuity analysis in context of the contemporary stress field may provide insight into the orientation of these fracture zones.

The proximity of the Goff 3D and Gepco 3D would suggest similar orientation trends. The average for the northeast trend differs by only one degree; however the average for the northwest trend differs by fifteen degrees between the two surveys. This is an example of the similarity and variability of interpreted seismic fracture zones between two proximal seismic surveys. The acquisition orientation of the 3D seismic survey may influence the interpretation of the 3D seismic discontinuities (Table 7). 


\begin{tabular}{|l|l|l|l|l|}
\hline Author & \multicolumn{1}{|c|}{ Year } & \multicolumn{1}{|c|}{ Location } & \multicolumn{1}{|c|}{ Method } & Shmax \\
\hline $\begin{array}{l}\text { Plum and } \\
\text { Cox }\end{array}$ & 1987 & Clinton County, PA & Borehole Breakouts & N64E \\
\hline $\begin{array}{l}\text { Plum and } \\
\text { Cox }\end{array}$ & 1987 & Clinton County, PA & Borehole Breakouts & N69E \\
\hline $\begin{array}{l}\text { Plum and } \\
\text { Cox }\end{array}$ & 1987 & Greene County, PA & Hydraulic Fracture & N96E \\
\hline $\begin{array}{l}\text { Parsons } \\
\text { and Dahl }\end{array}$ & 1972 & Wetzel County, WV & Drilling Induced Fracture & N67E \\
\hline unknown & unknown & Richie County, WV & Borehole Breakouts & N85E \\
\hline Roberts & 2013 & Clearfield County, PA & FMI Logs & N48E \\
\hline Wilson & 2015 & Monongalia County, WV & FMI Logs & N65E \\
\hline
\end{tabular}

Table 6: Summary of sources for contemporary stress orientations in the Appalachian basin near the study area in Harrison County West Virginia. Table summarizes author, year, location of the data point, method the data was collected and observed orientation of maximum horizontal stress.

\begin{tabular}{|l|l|l|l|l|l|c|}
\hline Author & Year & \multicolumn{1}{|c|}{ Location } & \multicolumn{1}{|c|}{ Method } & $\begin{array}{c}\text { NE } \\
\text { Trend }\end{array}$ & $\begin{array}{c}\text { NW } \\
\text { Trend }\end{array}$ & $\begin{array}{c}\text { Seismic } \\
\text { Orientation }\end{array}$ \\
\hline Zhu & 2013 & $\begin{array}{l}\text { Taylor } \\
\text { County, WV }\end{array}$ & $\begin{array}{l}\text { Seismic } \\
\text { Discontinuity }\end{array}$ & N52E & N45W & NW-SE \\
\hline Hart & 2014 & $\begin{array}{l}\text { Greene } \\
\text { County, PA }\end{array}$ & $\begin{array}{l}\text { Seismic } \\
\text { Discontinuity }\end{array}$ & N43E & N41W & N-S \\
\hline Kish & 2015 & $\begin{array}{l}\text { Harrison } \\
\text { County, WV } \\
\text { (Goff) }\end{array}$ & $\begin{array}{l}\text { Seismic } \\
\text { Discontinuity }\end{array}$ & N40E & N48W & N-S \\
\hline Kish & 2015 & $\begin{array}{l}\text { Harrison } \\
\text { County, WV } \\
\text { (Gepco) }\end{array}$ & $\begin{array}{l}\text { Seismic } \\
\text { Discontinuity }\end{array}$ & N26E & N30W & NW-SE \\
\hline
\end{tabular}

Table 7: Summary of case studies using 3D seismic discontinuity analysis with average trends interpreted for the Marcellus shale. 

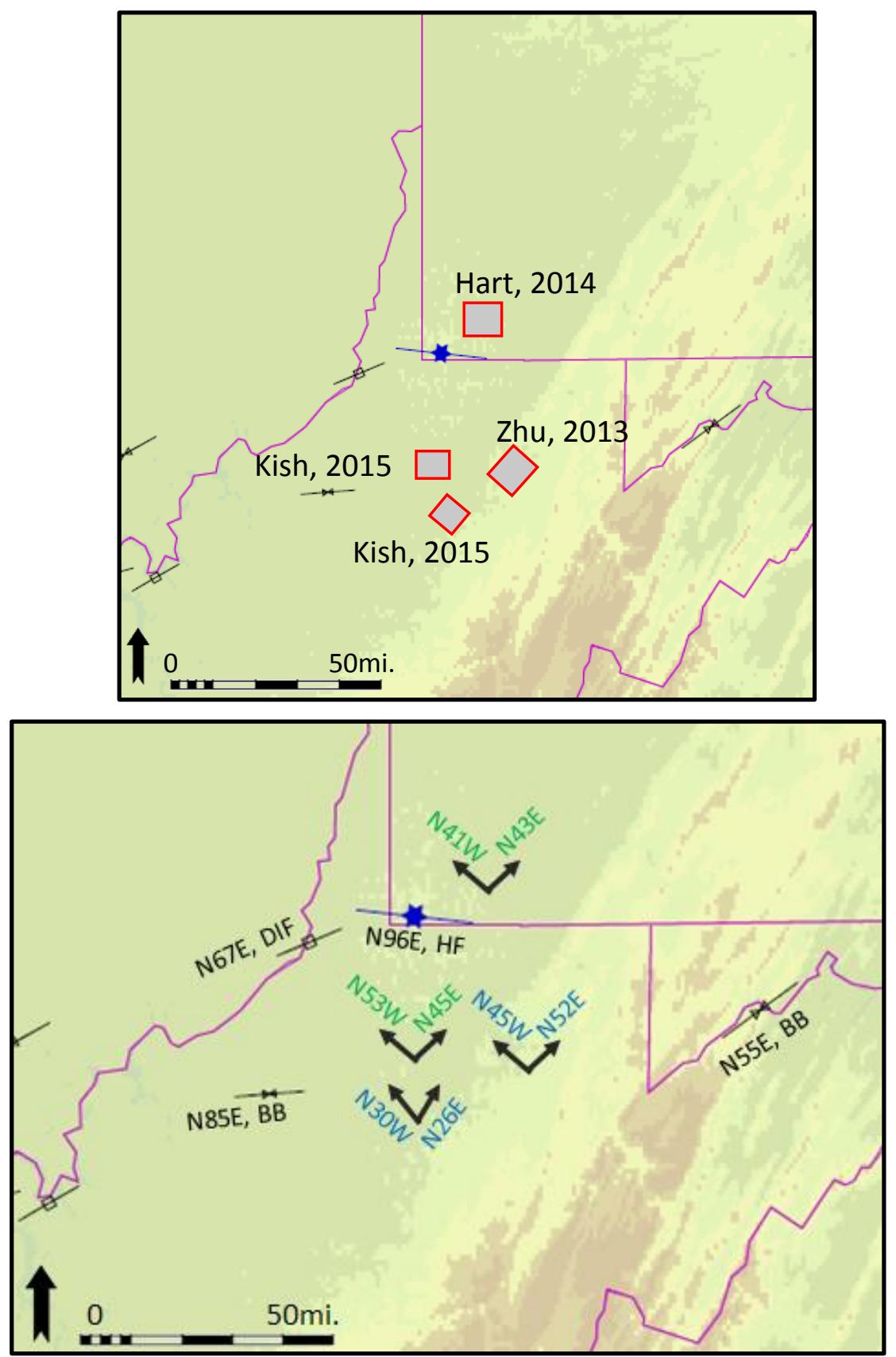

Figure 70: A: Location of four three dimensional seismic surveys where Marcellus shale seismic discontinuity analyses were completed. B: Major Marcellus shale discontinuity trends plotted with contemporary stress orientations. Maps modified from the World Stress Map Project (Zoback et al., 2008). 


\section{HYDROCARBON IMPLICATIONS}

\subsection{An Introduction to Hydrocarbon Production in the Appalachian Basin}

The first oil well in the Appalachian basin was the 1859 Drake Well in northeastern Pennsylvania. This well was 69.5 feet deep and produced oil from an Upper Devonian sandstone and sparked the first oil boom in the United States (Caplinger, 1997). Since then the Appalachian basin has continually produced oil and gas from various stratigraphic units. Currently, the Appalachian basin is experiencing a boom in production in the Middle Devonian Marcellus shale and Middle Ordovician Trenton limestone due to new technologies.

\subsection{Marcellus Shale Hydrocarbon Production}

Marcellus shale produces natural gas through the implementation of horizontal drilling and hydraulic fracturing. "Hydraulic fracturing is a known technology and has been used for at least 60 years. It has helped produce more than 600 trillion cubic feet of natural gas and 7 billion barrels of oil" (American Petroleum Institute, 2010). Hydraulic fracture treatments are a technique that is used to increase the permeability of the source rock by increasing hydrostatic pressure. The hydraulic fractures open pre-existing natural fractures leading to a significant increase in the permeability. This technology began in the 1940's and was used in limestone and sandstone source rocks. Due to shales extremely low permeability the technology was not advanced enough to work efficiently in shale source rocks, until the late 1970's to complete vertical shale wells. Today, the combination of lateral wells and hydraulic fracture treatment makes an extremely low permeability source rock, like the Marcellus shale, economical to produce. 
The Marcellus shale is now one of the largest producers of natural gas in the United States (Figure 71). The U.S. Energy Information Administration (2015) estimates a total of 64.9 trillion cubic feet of proved reserves in the Marcellus shale. Furthermore, the technology used for shale gas extraction is now so advanced and efficient that in 2013 shale gas wells have become the greatest producing wells in the United States (Figure 72).

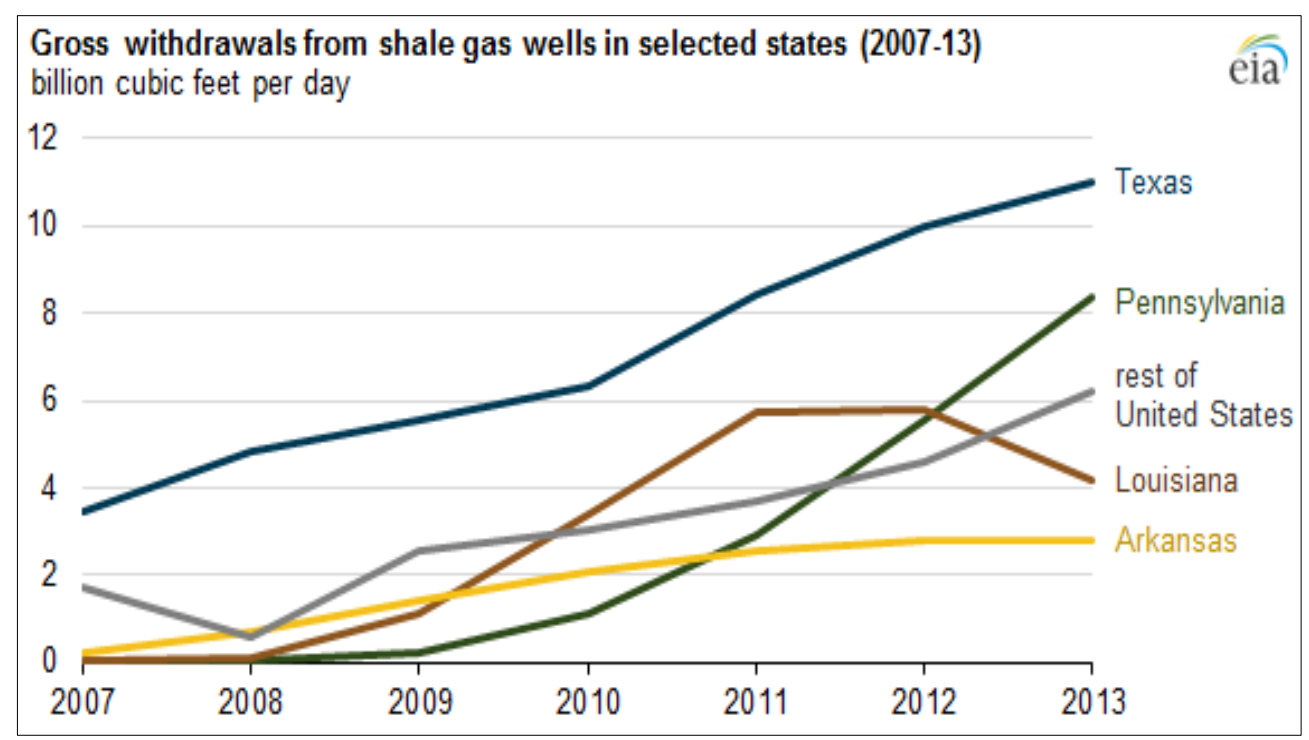

Figure 71: Graph from the United States Energy Information Administration (2014) depicting gas production in Pennsylvania (Appalachian basin) is quickly on the rise due to the hydraulic fracturing of the Marcellus shale.

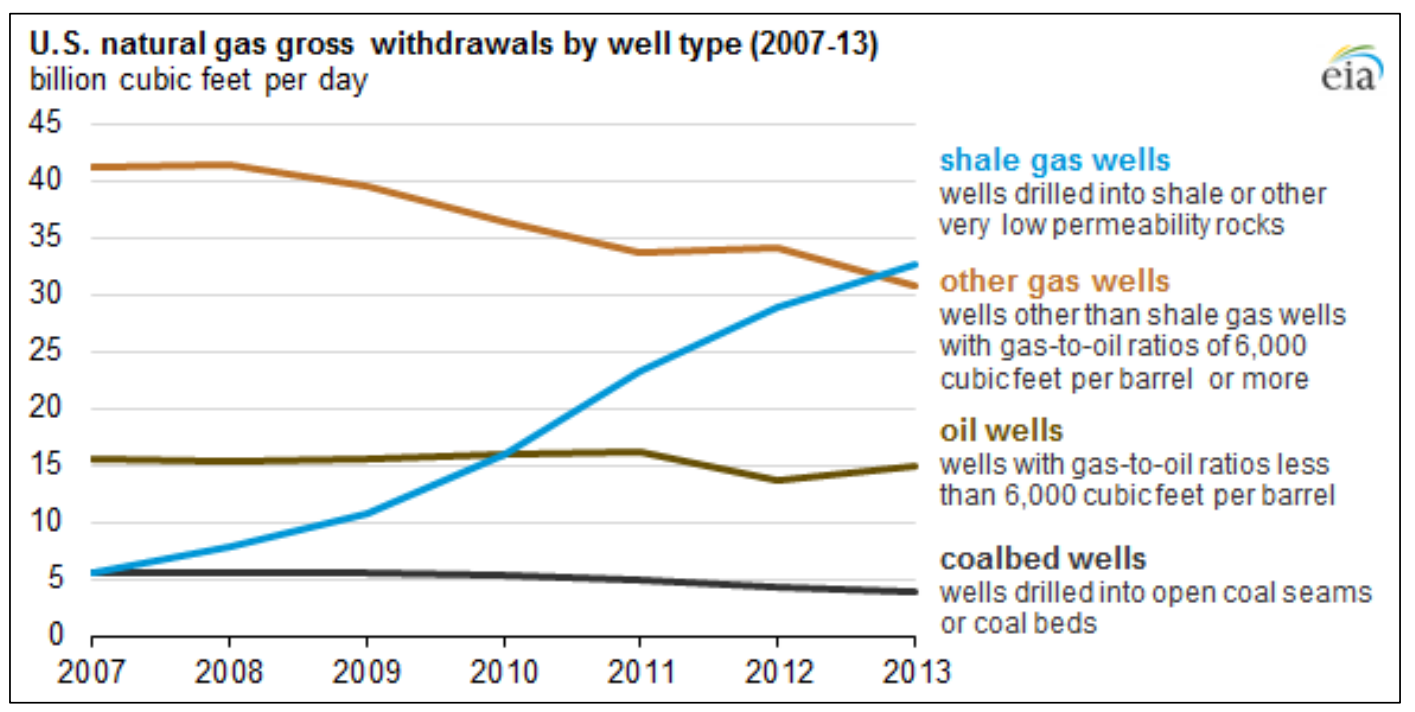

Figure 72: Graph from the United States Energy Information Administration (2014) depicting gas production in the United States showing that in 2013 shale gas production surpassed every other kind of production. 
However, with an increase in the number of wells being drilled, increasing proximity of these wells to one another, and the increasing demand for natural gas energy production, there is always room for improvement. Analyzing the production of existing Marcellus shale wells within the study area may provide insight into differences in production and association with well $\log$ and 3D seismic information.

\subsubsection{Analysis of Existing Marcellus Shale Wells}

According to the Unconventional Energy Resources Atlas (2014), Harrison County is the eighth most productive county for unconventional shale gas drilling out of all the counties in Pennsylvania, Ohio and West Virginia that are implementing horizontal drilling techniques (Table 8). Moreover, Harrison County is the number one most productive county in the state of West Virginia with a cumulative production of 183,996,011.00 Mcf, as of December 2014.

\begin{tabular}{|c|c|c|c|}
\hline $\begin{array}{c}\text { Largest } \\
\text { Producers }\end{array}$ & County & State & $\begin{array}{c}\text { Cumulative Gas Production } \\
\text { Mcf }\end{array}$ \\
\hline 1 & Bradford & PA & $1,630,459,107.99$ \\
\hline 2 & Susquehanna & PA & $1,413,423,637.66$ \\
\hline 3 & Lycoming & PA & $740,277,061.21$ \\
\hline 4 & Greene & PA & $676,027,492.04$ \\
\hline 5 & Washington & PA & $635,857,400.77$ \\
\hline 6 & Tioga & PA & $598,405,487.61$ \\
\hline 7 & Wyoming & PA & $220,884,424.33$ \\
\hline 8 & Harrison & WV & $183,996,011.00$ \\
\hline 9 & Westmoreland & PA & $158,910,103.32$ \\
\hline 10 & Fayette & PA & $120,551,778.19$ \\
\hline
\end{tabular}

Table 8: Information obtained from the Unconventional Hydrocarbon Resources Atlas showing the top 10 natural gas producing counties in $\mathrm{PA}, \mathrm{OH}$ and $\mathrm{WV}$ as of December 2014. Harrison County is the only county from WV in the top 10. Note: cumulative production is from the start date of the wells within each county and unconventional development may have started earlier in some areas. 
There are fifteen Marcellus shale wells within and around the Goff 3D and Gepco 3D seismic surveys. The monthly production of these wells is reported on the West Virginia Geological and Economic Survey Pipeline Plus website on a yearly basis. The first year cumulative was calculated for each of the fifteen wells and summarized in Figure 73. The cumulative production data was calculated on the first twelve months of production and rarely coincides with a calendar year, which is why the year of production is not reported. As an attempt to normalize the cumulative production the length of the lateral was taken into consideration. The first year cumulative production is reported in Figure 74 on a per foot of lateral well basis. Only fourteen of the fifteen wells in the study area had lateral length information reported. Comparing Figures 73 and 74 shows that the length normalization changes what is perceived to be the best producing wells exemplifying the importance to normalize gas production based on length of the lateral well.

The total reported production for all wells is summarized in Figure 75. The Goff 3HM and Goff 4HM have the longest history of production, over four years, but do not have the highest amount of production. The length of the lateral was also taken into consideration for cumulative production analyses and is summarized in Figure 76. The total three year cumulative production for the Goff 5HM, 9HM and 10HM have a similar per foot production as the four year cumulative of the Goff $3 \mathrm{HM}$ and $4 \mathrm{HM}$. This indicates that the Goff 5HM, 9HM and 10HM are better producing wells than the Goff 3HM and Goff 4HM. 


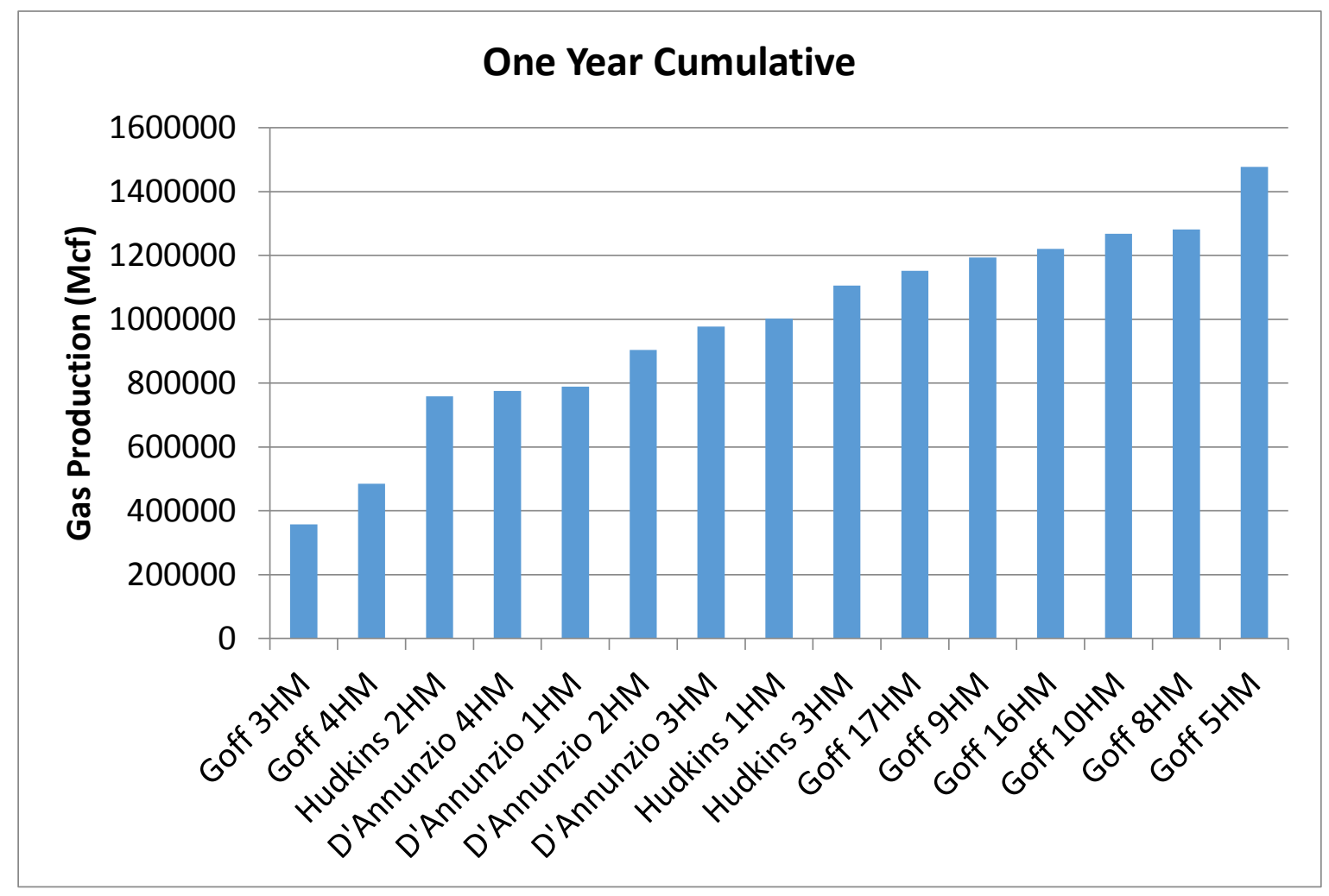

Figure 73: Graph showing the first 12 months of production of all the Marcellus shale wells in the study area from least production to greatest production.

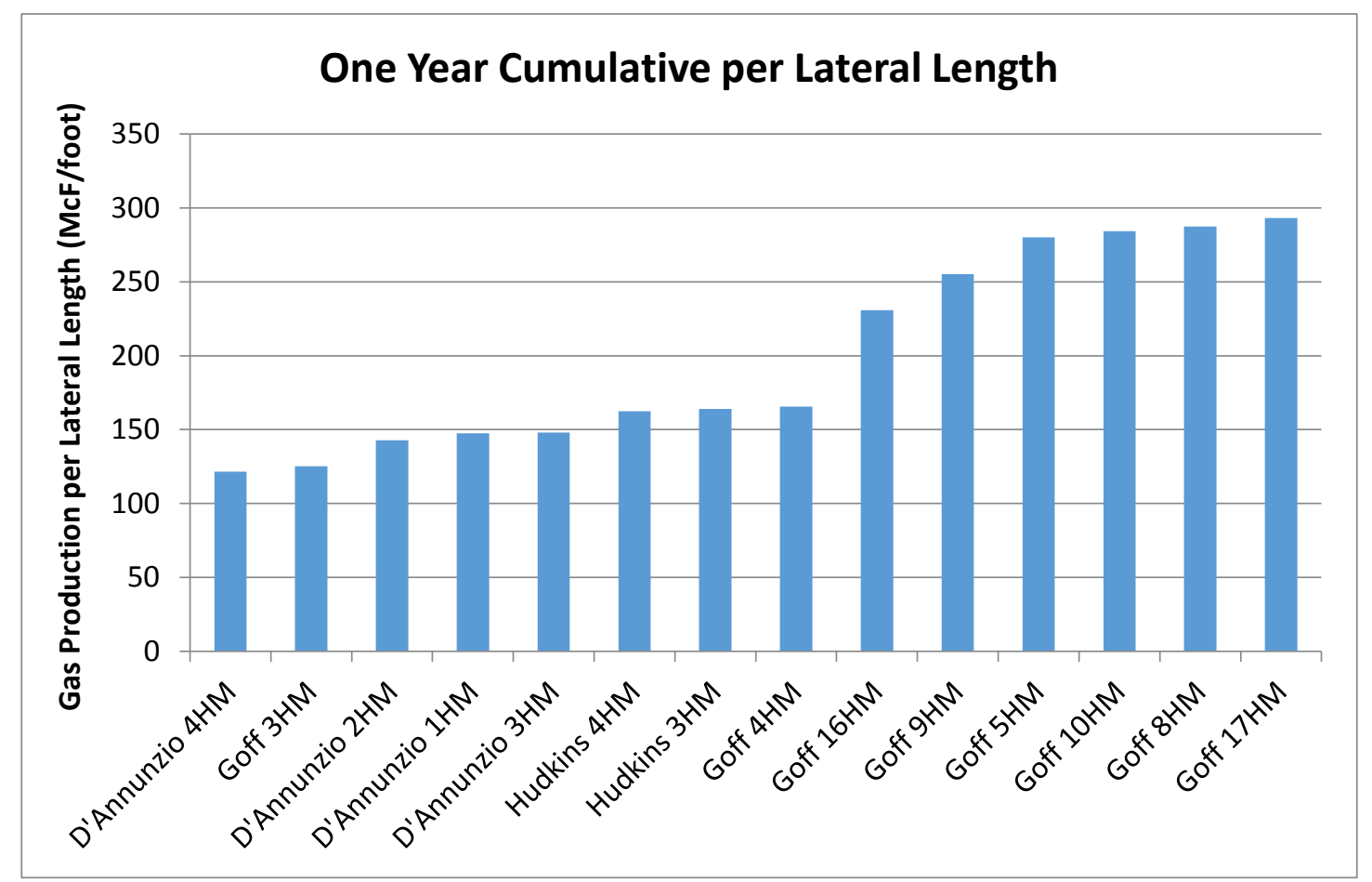

Figure 74: Graph showing the same 12 month production but on a per foot basis based on lateral length. Note the changes in which wells are viewed as best producer. 


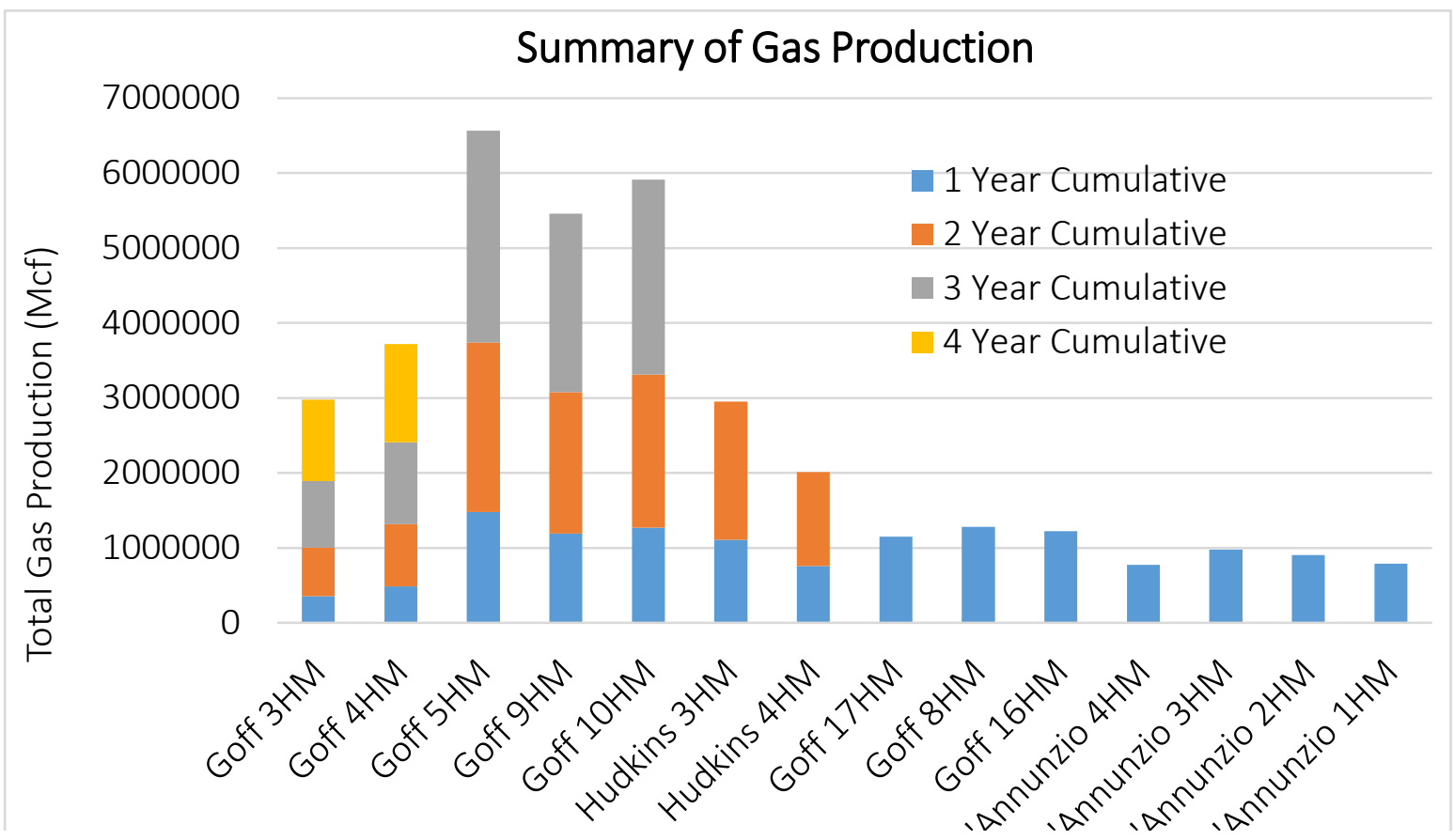

Figure 75: Graph showing all of the production since first month of production for all the wells in the study area.

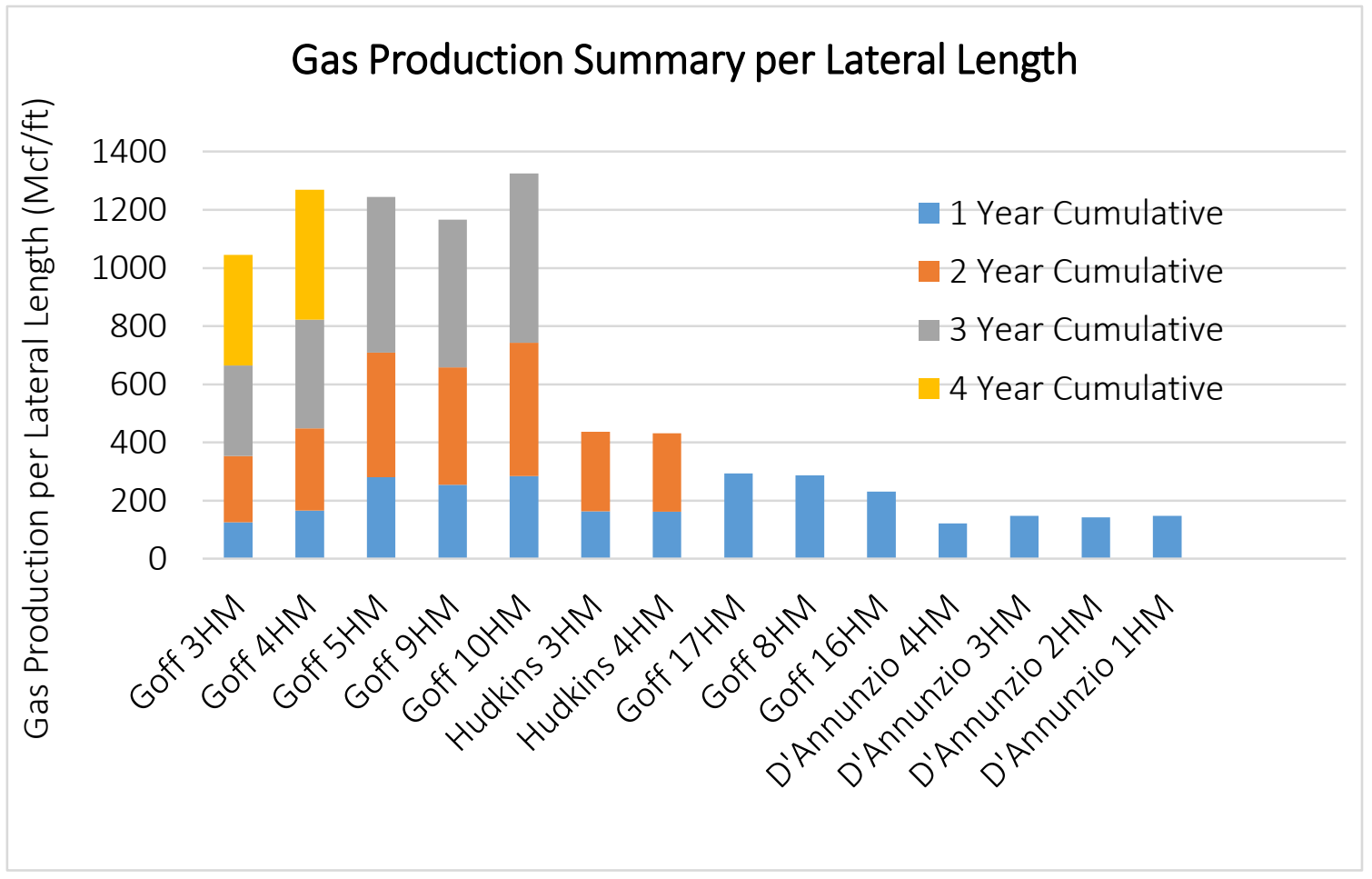

Figure 76: Graph showing all of the production since first month of production for all the wells in the study area on a per foot basis. 
First, second, and third year cumulative production of nine wells with 3D seismic coverage were assessed in context of seismic discontinuity analysis. The 3D seismic interpreted subtle faults and fracture zones may aid in gas production by providing more preexisting natural conduits for fluid flow. The frequency of seismic discontinuities, see Section 5.5: Natural Fracture Analysis, that crossed each lateral well was determined, Figure 77. This data (Table 9) was plotted against first, second and third year cumulative per lateral length production. The resulting analysis produced a positive correlation between seismic discontinuity frequency across the lateral well and total gas production normalized by lateral length (Figures 78, 79 and 80 respectively). The correlation coefficient between these two parameters increased from 0.82 to 0.88 to 0.97 with first, second and third year cumulative production respectively. The third year cumulative production has the highest correlation coefficient with seismic discontinuity frequency (Figure 80).

Initially, only the frequency of discontinuities that crossed the well path were calculated. However, this was next normalized by length of the lateral to analyze the amount of discontinuities per foot of lateral well. Figures 81,82 , and 83 plot the frequency of discontinuities per 1000 feet of lateral well versus the first, second and third year cumulative production respectively. By normalizing discontinuities based on lateral length the linear regression for each cumulative production year was improved to yield correlation coefficients of $0.92,0.95$, and 0.96 respectively. This data emphasizes the importance to not only normalize the gas production by lateral length but to also normalize the frequency of discontinuities based on the length of the lateral. 
The data suggest a linear trend however two separate data clusters are observed in the seismic discontinuity frequency and gas production analyses. One cluster has low discontinuities crossing the wellbore and low gas production, the other data cluster exhibits both a greater numbers of seismic discontinuities and relatively higher gas production. Spatially, by well pad, there seems to be no correlation between these two clusters. For example, the well pad in the south central portion of the Goff 3D seismic survey has three horizontal wells: 17HM, 16HM and $8 \mathrm{HM}$. The Goff $17 \mathrm{HM}$ and $8 \mathrm{HM}$ plot in the high discontinuity high production cluster and the Goff $16 \mathrm{HM}$ plots in the low discontinuity low production cluster. This eliminates the variable that wells from the same pad will always plot in the same data cluster.

Overall, wells with a greater frequency of seismic discontinuities (interpreted as subtle fracture and fault zones) that cross the wellbore are shown to have larger volumes of cumulative gas production than wells with a lesser frequency of seismic discontinuities that cross their lateral well. Future analyses on other three dimensional datasets with lateral wells should be completed to further test this correlation. 


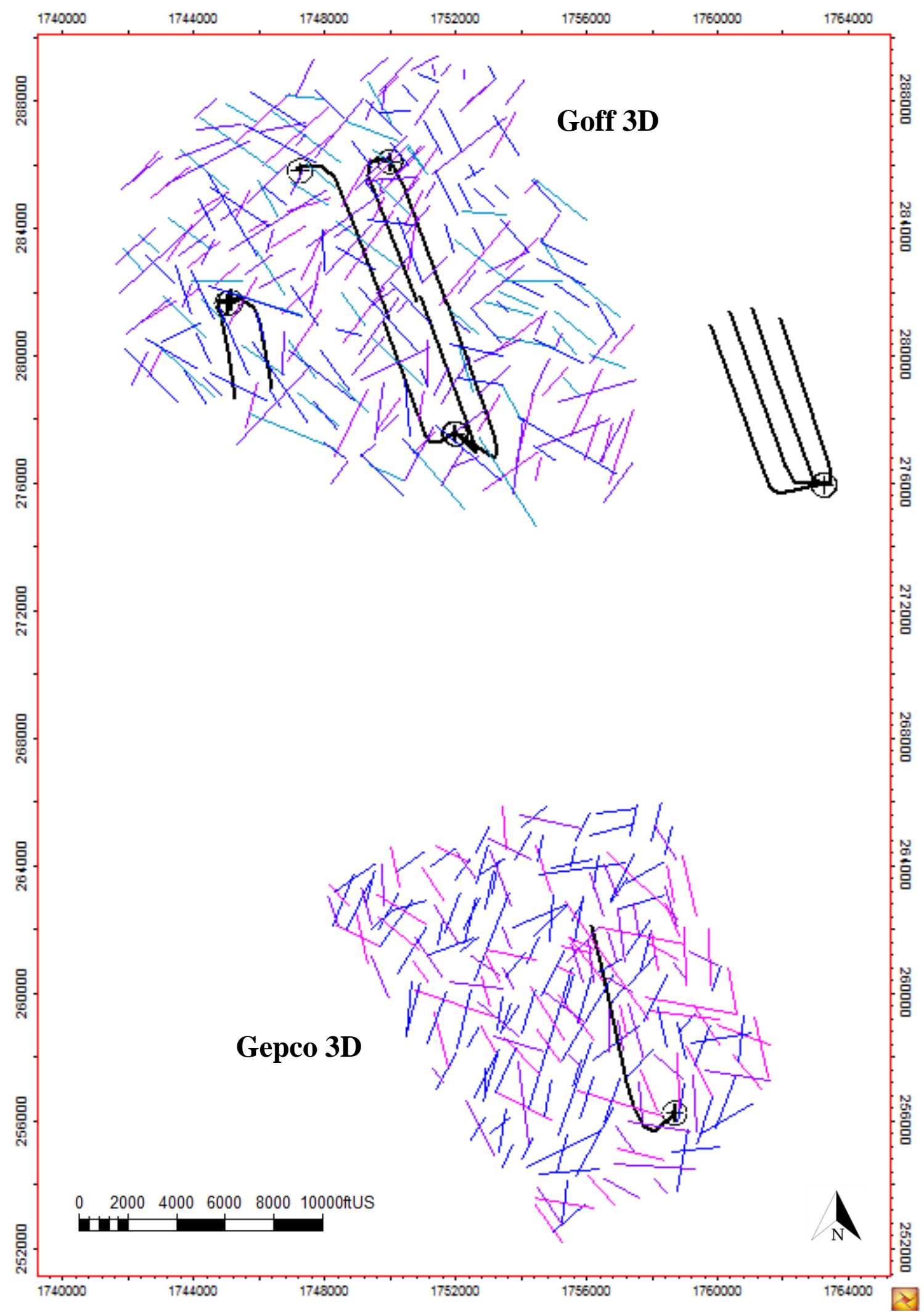

Figure 77: Interpreted seismic discontinuities near the Marcellus shale for the Goff 3D and Gepco 3D with the horizontal Marcellus shale wells plotted. 


\begin{tabular}{|l|l|l|l|l|}
\hline Well Name & $\begin{array}{c}1^{\text {st }} \text { Year } \\
\text { Cumulative } \\
\text { (Mcf/ft) }\end{array}$ & $\begin{array}{c}2^{\text {nd }} \text { Year } \\
\text { Cumulative } \\
\text { (Mcf/ft) }\end{array}$ & $\begin{array}{r}3^{\text {rd }} \text { Year } \\
\text { Cumulative } \\
\text { (Mcf/ft) }\end{array}$ & $\begin{array}{r}\text { Number of Seismic } \\
\text { Discontinuities Crossing } \\
\text { Lateral Well }\end{array}$ \\
\hline Goff 3HM & 125.3509 & 227.9683878 & 311.2096944 & 2 \\
\hline Goff 4HM & 165.5411 & 283.3318539 & 373.5554797 & 3 \\
\hline Goff 5HM & 279.9865 & 429.1127321 & 534.5303145 & 9 \\
\hline Goff 9HM & 255.1046 & 403.1655261 & 508.469846 & 9 \\
\hline Goff 10HM & 284.3195 & 458.806278 & 582.4934978 & 10 \\
\hline Goff 17HM & 293.2226 & - & - & 8 \\
\hline Goff 8HM & 287.4280 & - & - & 4 \\
\hline Goff 16HM & 121.5626 & - & - & 6 \\
\hline Hudkins 3HM & 163.9305 & 273.5015562 & - & 8 \\
\hline
\end{tabular}

Table 9: Summary of the nine wells within the seismic surveys that have horizontal deviation surveys and at least one years of production data.

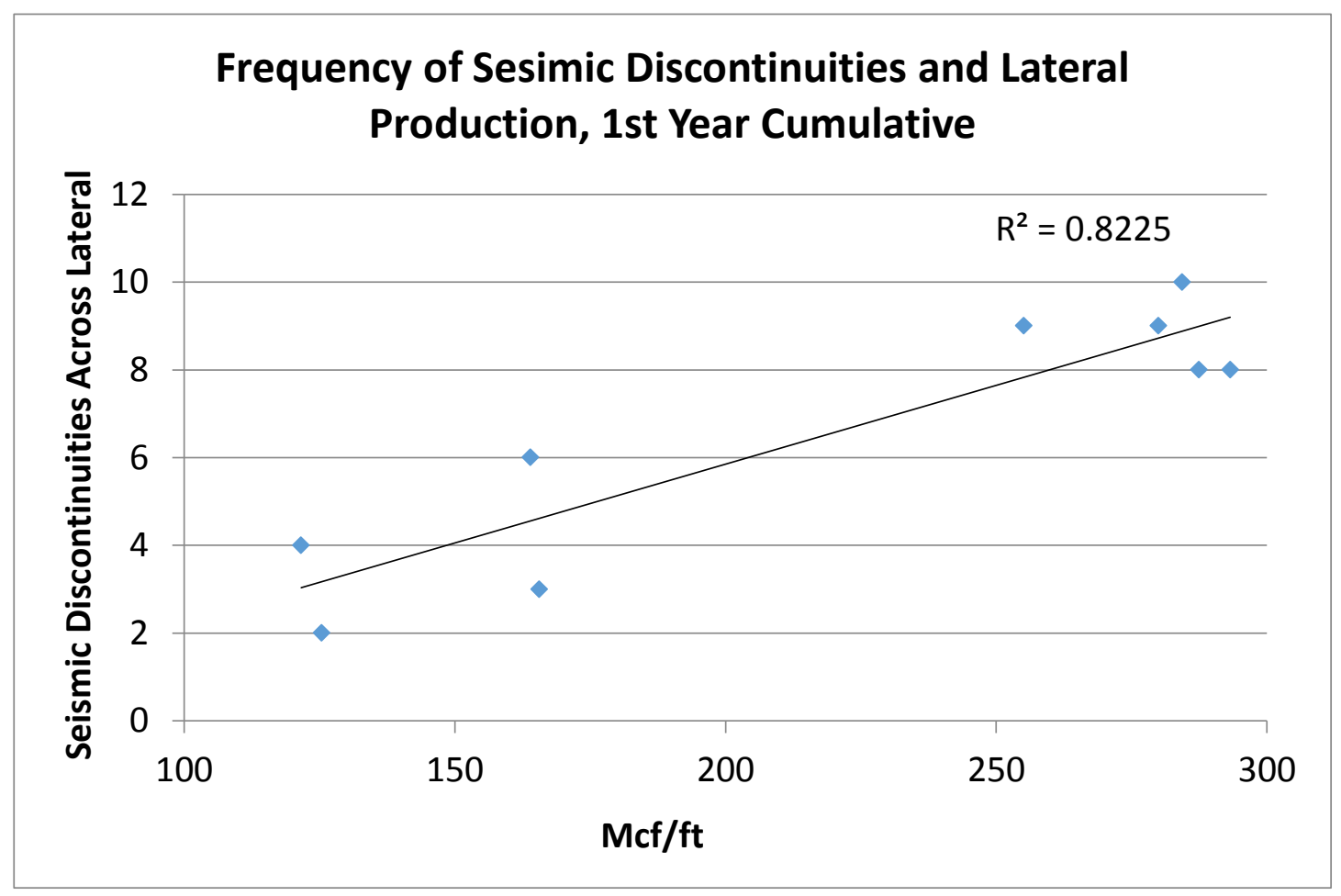

Figure 78: Cross plot of first year cumulative production data and frequency of interpreted seismic discontinuities that intersect the horizontal well. 


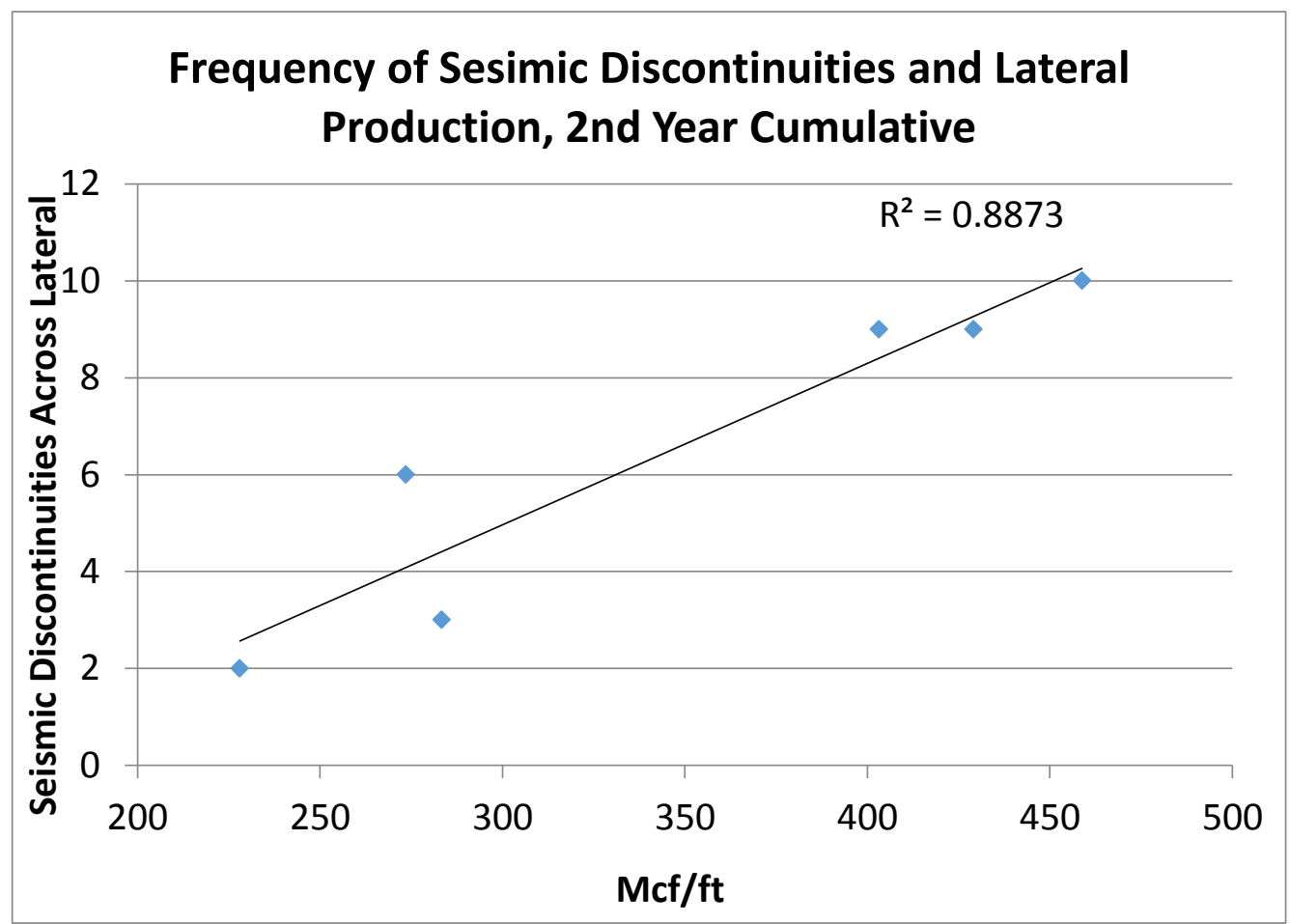

Figure 79: Cross plot of second year cumulative production data and frequency of interpreted seismic discontinuities that intersect the horizontal well.

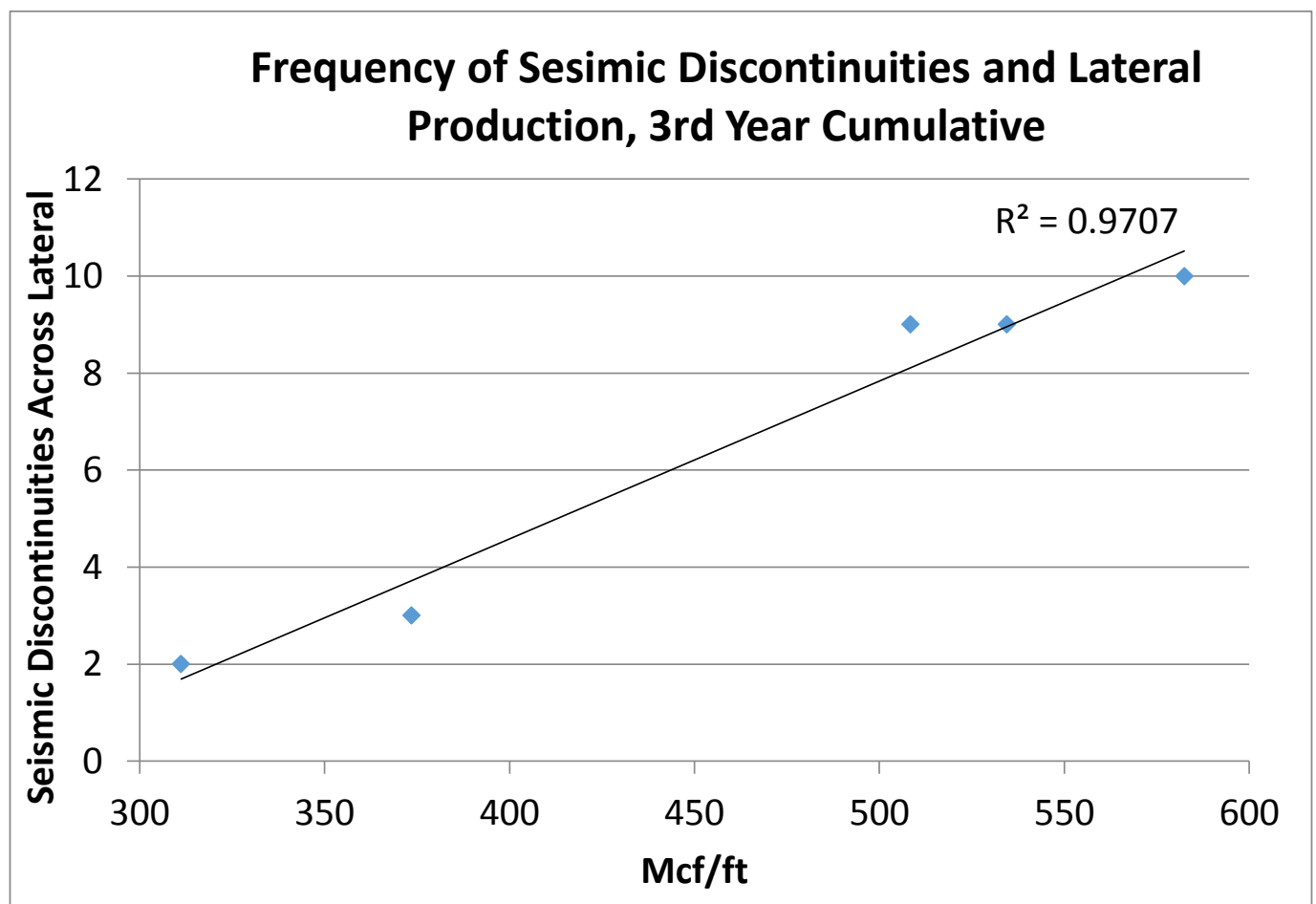

Figure 80: Cross plot of third year cumulative production data and frequency of interpreted seismic discontinuities that intersect the horizontal well. 


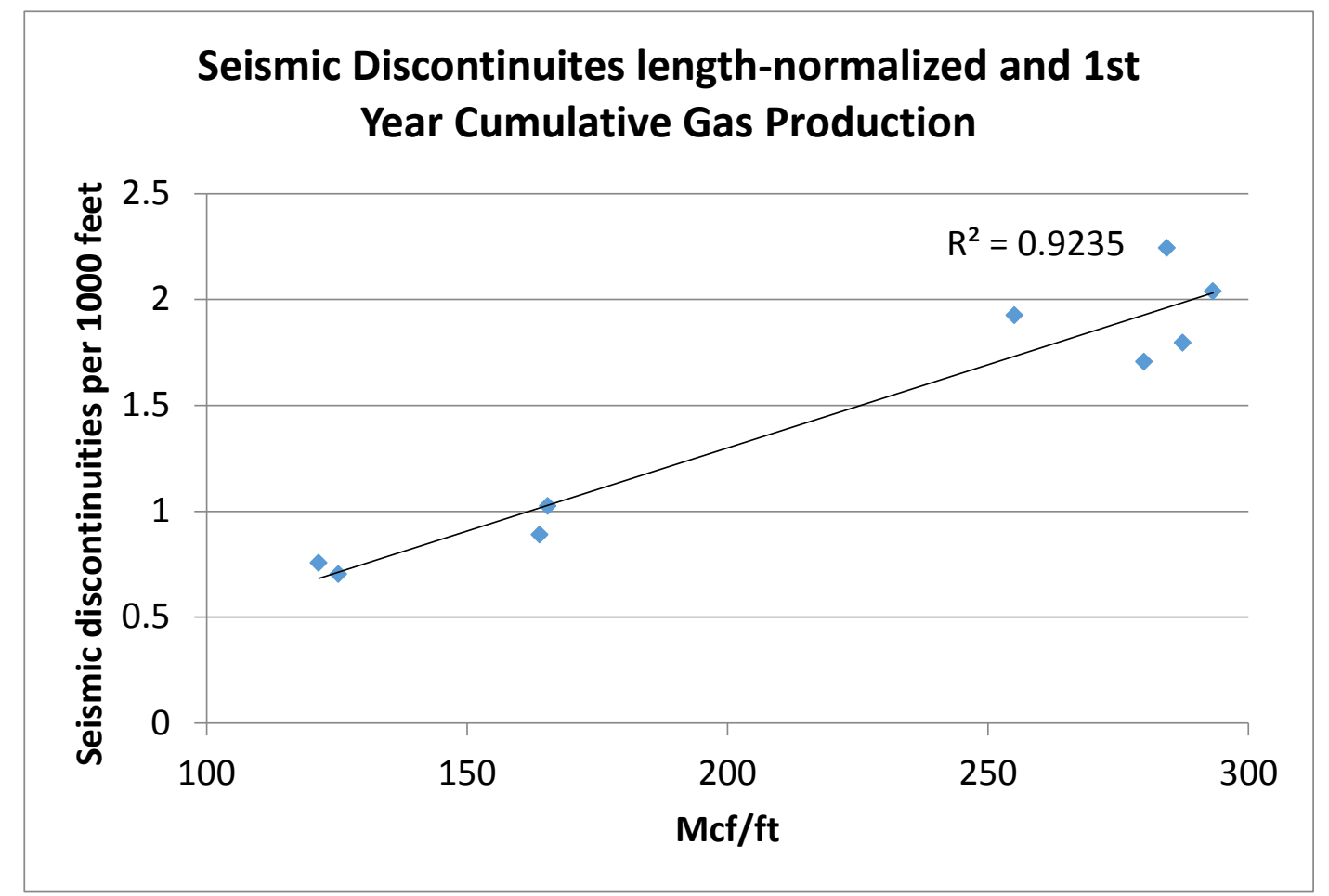

Figure 81: Cross plot of first year cumulative production and frequency of seismic discontinuities that intersect the horizontal well normalized by length.

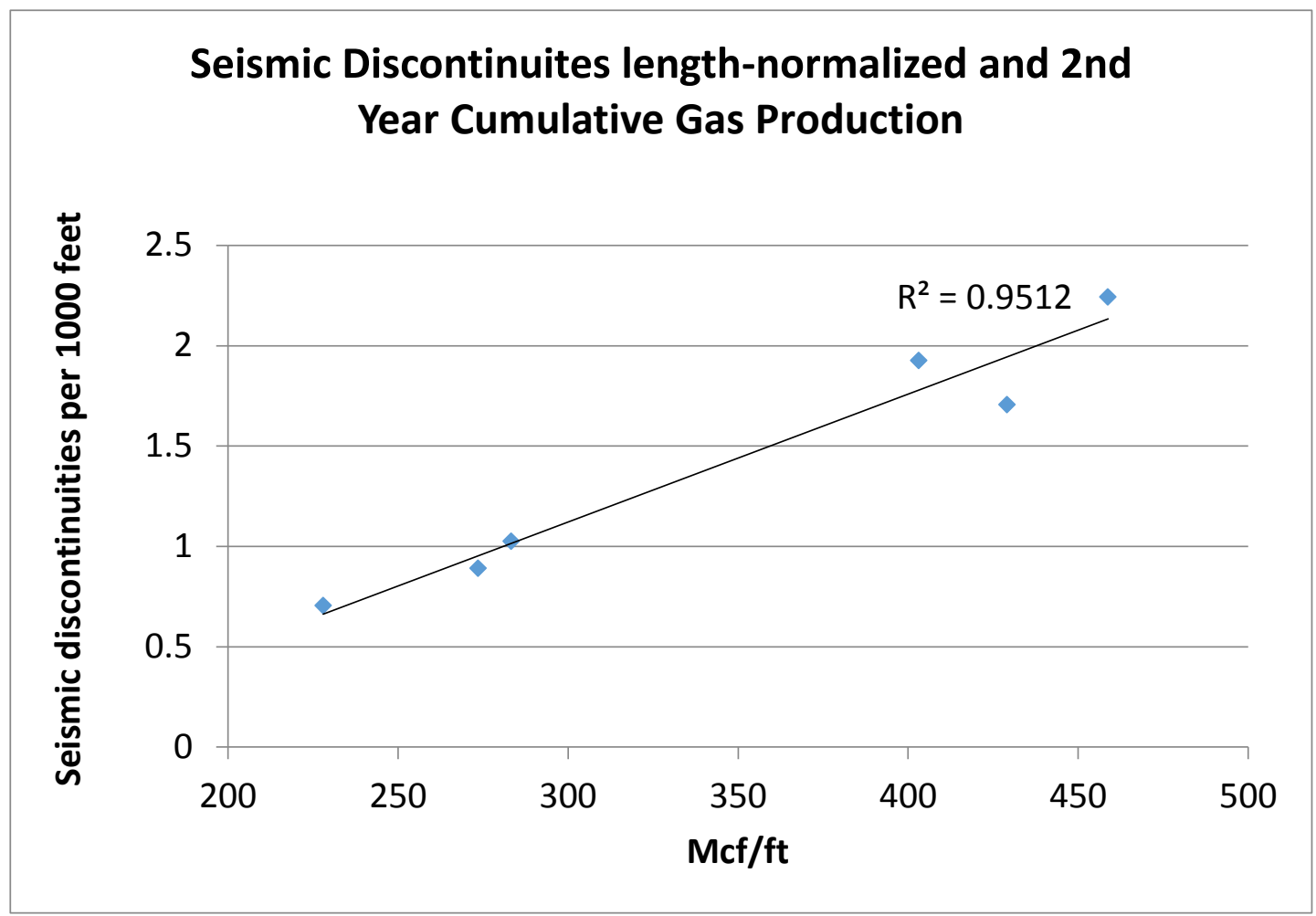

Figure 82: Cross plot of second year cumulative production and frequency of seismic discontinuities that intersect the horizontal well normalized by length. 


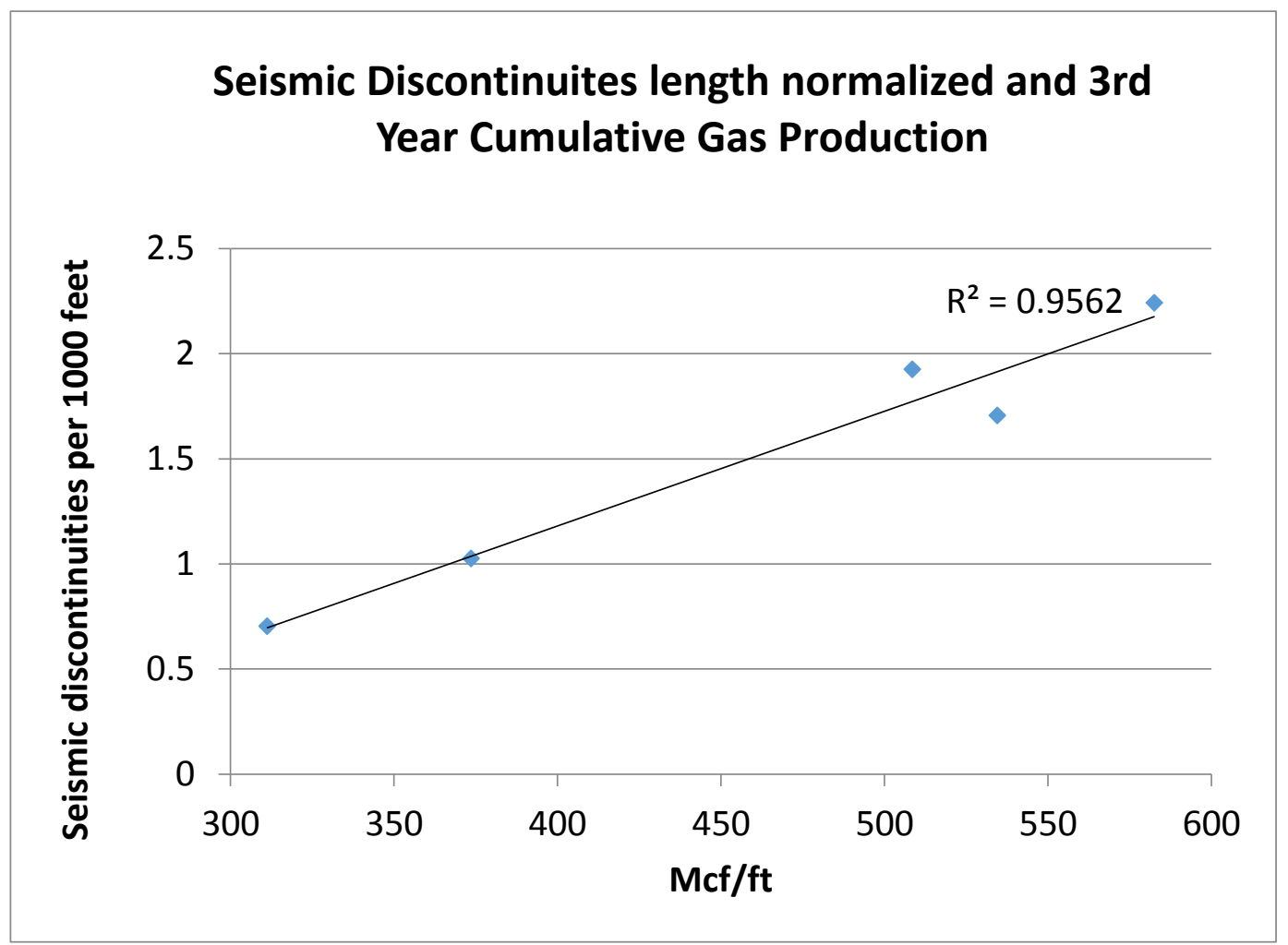

Figure 83: Cross plot of third year cumulative production and frequency of seismic discontinuities that intersect the horizontal well normalized by length. 
To further assess the production of these Marcellus shale wells, a decline curve analysis was completed as part of this research. Unconventional development production decline curves were created referencing a hyperbolic curve fit used by leading companies in unconventional shale development (Figure 84). Production decline curves were manually fit for 167 Marcellus shale wells in Harrison County West Virginia using IHS's Petra ® (Figure 85 A and B). The estimated ultimate recovery (EUR) was normalized by per foot lateral length for each of these wells assuming a 20 year production history. A contour map of Harrison County of Marcellus shale EUR on a per foot lateral basis was produced (Figure 86). This map highlights the most productive Marcellus shale wells in Harrison County. This map shows the distribution of wells that have low expected EUR and wells that have the highest expected EUR. This map may aid in planning future well locations. Production values used to construct the map were located at the toe of each lateral.

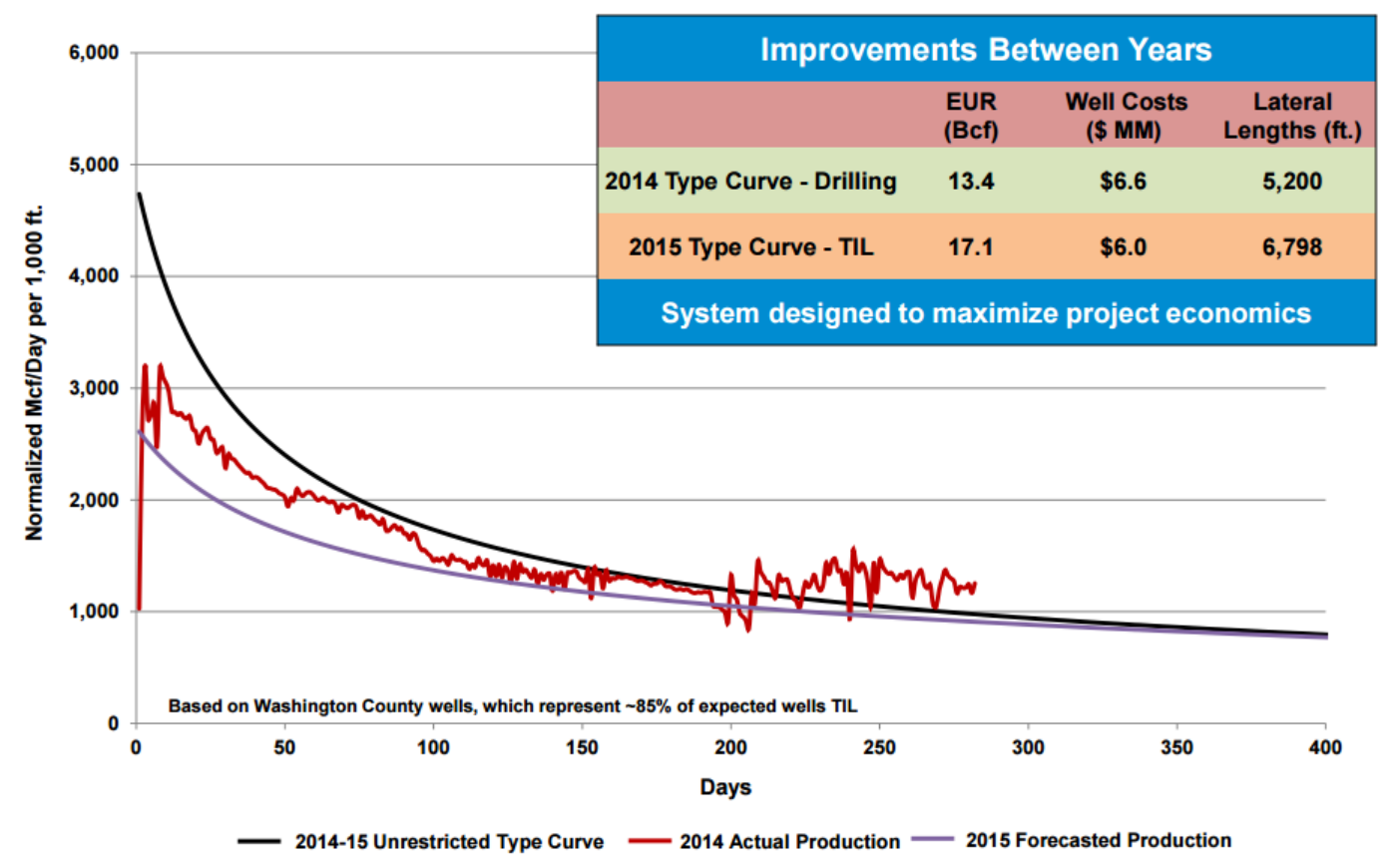

Figure 84: Type curve example showing how Range Resources (2015) does their decline curve for unconventional shale gas production estimates to obtain EUR. 

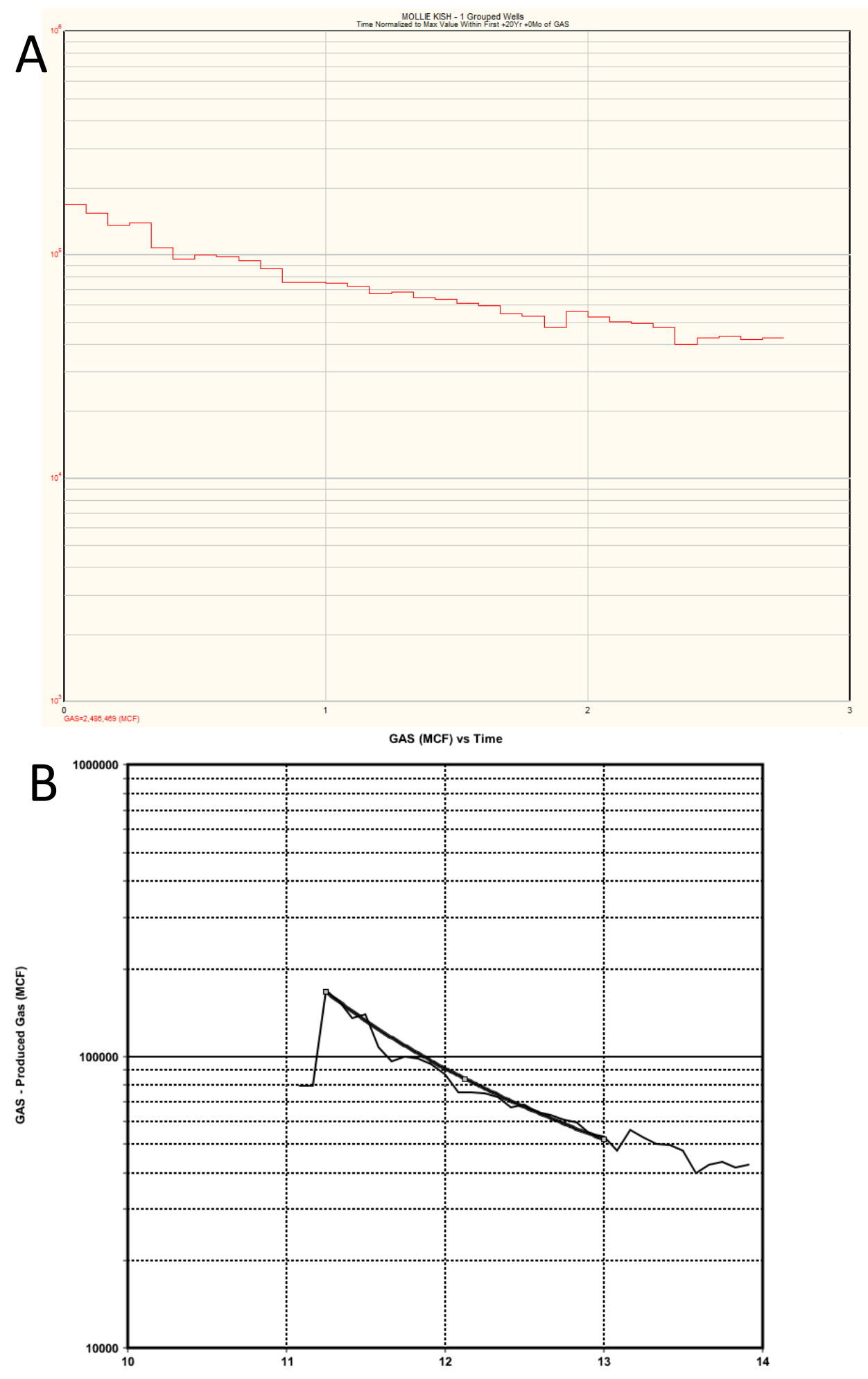

Figure 85: A: Petra's Production Group Normalization Plot showing the monthly gas production for the Goff 5HM well. B: Petra's Decline Curve Analysis showing the manual hyperbolic fit line to estimate EUR over a 20 year production history for the same well. 


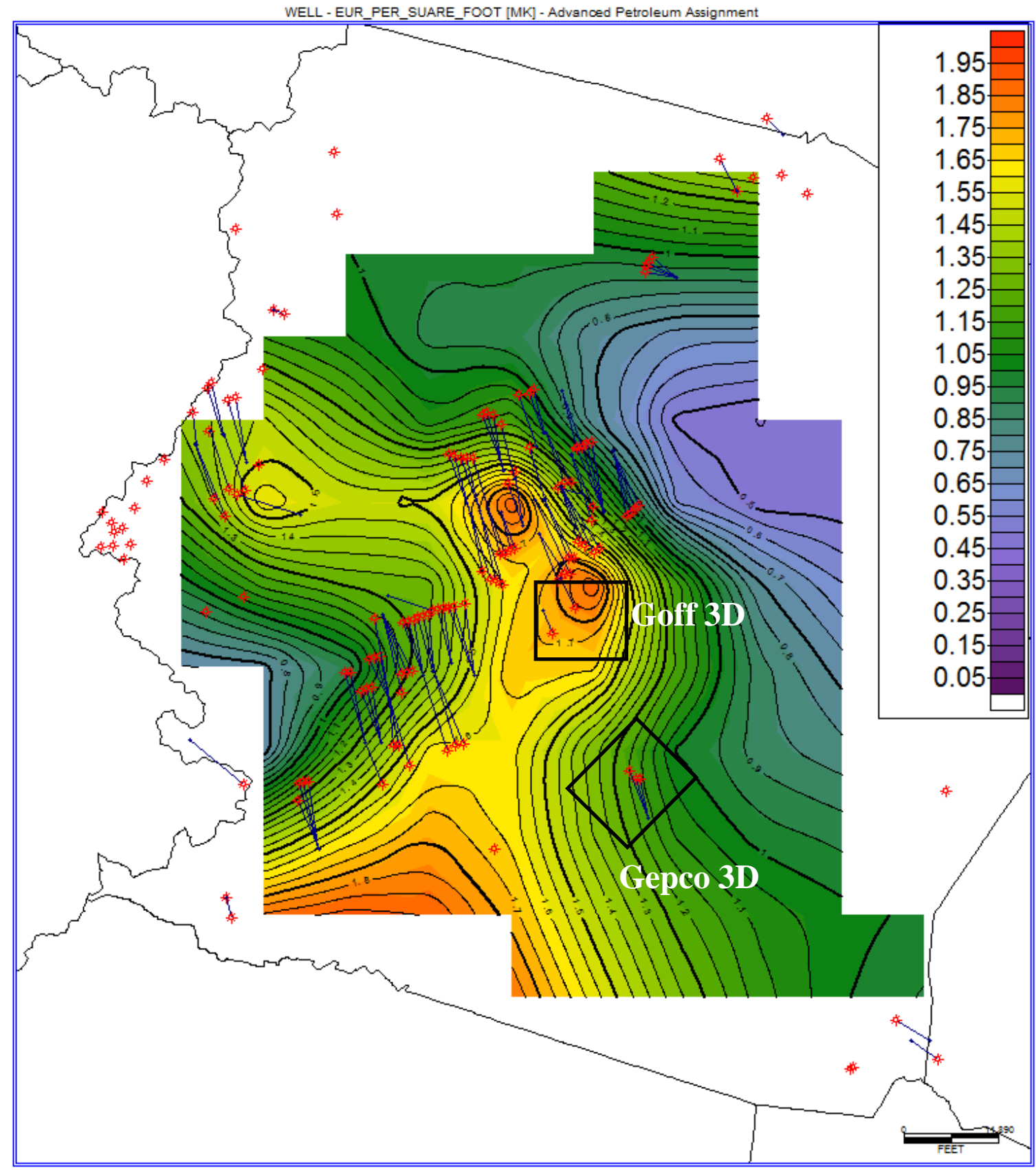

Figure 86: Estimated ultimate recovery contour map based on lateral length. Each well's EUR data is posted at the toe of each lateral. The higher expected EUR wells are located in proximity to the trend of the axis of the Wolf Summit Anticline. Approximate locations of the Goff 3D and Gepco 3D seismic surveys are labeled. 
Similar production decline analyses was completed in context of seismic discontinuities to assess if lateral wells with a higher frequency of seismic discontinuities had a higher initial decline in production. Intuitively, a lateral well crossing more preexisting subtle fractures would be more amenable to hydraulic fracture stimulation and produce a higher volume of gas faster than a well with less preexisting fractures. The Goff 3HM and Goff 10HM were used for this analysis. The Goff $3 \mathrm{HM}$ has two interpreted seismic discontinuities crossing the lateral well and the Goff 10HM has ten interpreted seismic discontinuities crossing its lateral. The percent decrease in per lateral foot gas production between the first and second years or production and between the second and third years of production for both wells were analyzed (Table 10). The well with only two interpreted preexisting subtle fractures has a steady decrease in production each year at $18 \%$. The well with ten interpreted preexisting subtle fractures has a higher percent decrease every year, indicating these interpreted preexisting subtle fractures may play a role in initial production rates.

\begin{tabular}{|c|c|c|c|c|}
\hline Study Well & $\begin{array}{c}\text { Production } \\
\text { Year }\end{array}$ & McF Gas & $\begin{array}{c}\text { Per Lateral } \\
\text { Foot McF Gas }\end{array}$ & \% Decrease \\
\hline & 1st Year & 356874 & 125.3508957 & \\
\hline \multirow{2}{*}{ Goff 3HM } & 2nd Year & 292152 & 102.6174921 & 18.13581 \\
\hline & 3rd Year & 236988 & 83.24130664 & 18.88195 \\
\hline & 1st Year & 1268066 & 284.3197309 & \\
\hline Goff 10HM & 2nd Year & 778210 & 174.4865471 & 38.63017 \\
\hline & 3rd Year & 551645 & 123.6872197 & 29.11361 \\
\hline
\end{tabular}

Table 10: Analysis of two wells with dissimilar frequency of interpreted seismic discontinuity frequency crossing the lateral well. 
The cumulative gas production was also analyzed in context of the thickness of the Marcellus shale. The local Marcellus shale was found in the Goff 3D seismic dataset to have a concentrated area of increased Marcellus shale thickness. The production of wells within this local depocenter were compared to the production of wells outside of this depocenter. The Goff 8HM, 16HM and 17HM land in an area of increased thickness, with an average Marcellus shale thickness of 110 feet. These wells are compared to the Goff 5HM, Goff 9HM and Goff 10HM which are in close proximity to the previously mentioned wells and the laterals are oriented in the same directions. The Goff 5HM, Goff 9HM and Goff 10HM are over an area with an average of 90 feet thickness for the Marcellus shale. The 8HM, 16HM and 17HM only have enough monthly production reported to perform a first year production analysis. Lateral length normalized gas production is variable at each well between the two areas of different thicknesses (Figure 87). No correlation between Marcellus shale thicknesses, the local Marcellus shale depocenter and gas production is observed.

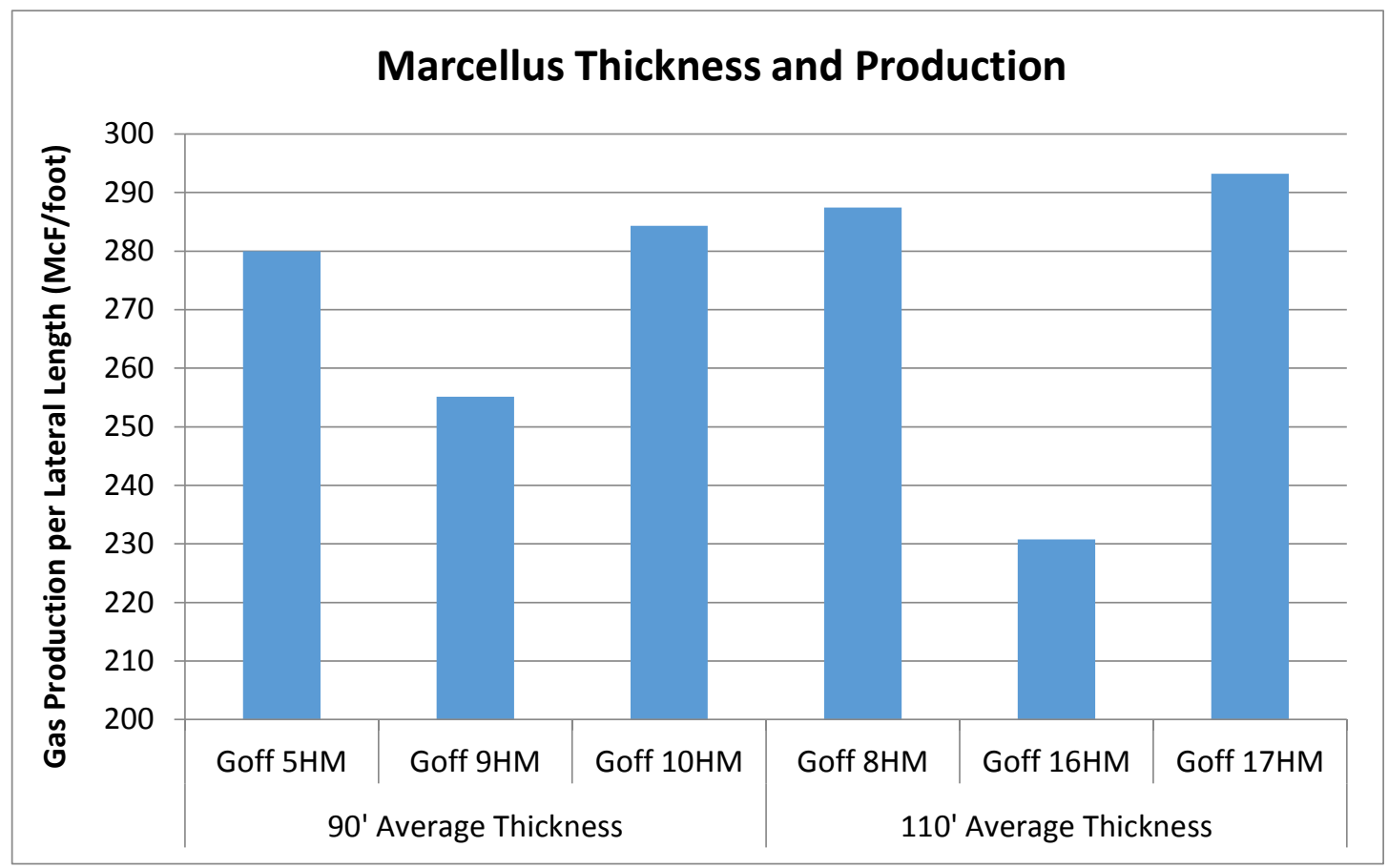

Figure 87: Comparison of gas production at multiple well sites with varying Marcellus shale thicknesses. 


\subsubsection{Recommendations for Future Marcellus Shale Development}

The existing wells within the 3D seismic surveys with the highest lateral length normalized first year production are the Goff 5HM, 8HM, 9HM, 10HM, 16HM and 17HM. These wells have at least double the interpreted seismic discontinuities than the other wells. These wells spread between inside and outside of the local Marcellus shale depocenter and their production has no correlation with Marcellus shale thickness. Based on the positive correlation with interpreted seismic discontinuities and gas production there is a recommendation of landing wells where there is a higher frequency of interpreted seismic discontinuities, if 3D seismic data is available prior to drilling. Areas for suggestion include more laterals surrounding these high producing wells such as a lateral to the east of Goff 10HM and to the east of Goff 16HM. 


\section{SUMMARY AND CONCLUSIONS}

The results of this study help improve our understanding of the subsurface geology and gas production from the Marcellus shale within Harrison County West Virginia. The mechanical stratigraphy and subtle fault analyses developed in this study improve our understanding of factors that may influence unconventional gas production in the area.

Brittleness and mineralogy were interpreted at the Goff \#55 well location within the Goff 3D seismic dataset and compared to other wells in a regional context. The results suggest that mechanical properties are variable and site dependent. Conclusive ranges for Poisson's ratio and Young's modulus constraints for areas of high brittleness and high total organic cannot be developed for an entire shale play but may be useful in local analyses. Structure maps and thickness maps of Middle Devonian stratigraphy were created to analyze thickness changes and fault reactivation history. Reactivation of a basement fault within the Goff 3D seismic dataset shows thickening and thinning of different intervals. The Marcellus shale thickness was analyzed in context of first year cumulative gas production and no correlation was observed. Subtle faults and small fracture zones were interpreted on the Marcellus shale surface using post stack seismic processing workflows. The frequency of these interpreted discontinuities across lateral wells was analyzed in context of gas production and a positive correlation was observed. The final recommendations for locations of future Marcellus shale wells include placing more horizontal wells in areas of high frequency of interpreted seismic discontinuities such as to the east of Goff $10 \mathrm{HM}$ and to the east of Goff 16HM. 


\section{FUTURE WORK}

The analyses presented in this study on the Goff \#55 well log represent the second thesis produced from this data. The first was a core and log study completed by Hilliard in 2015 . Future work that uses log data may include a comprehensive analysis of density and sonic logs and their relationship to seismic response. This would be especially interesting on the seismic volumes that have been processed and are a higher resolution than the seismic volumes used in this study.

The analyses completed on the Goff 3D and Gepco 3D provide the first thesis produced from this seismic data. Further analyses on the seismic data may include incorporation of updated well information; new wells that have been drilled since the start of this research, seismic inversion, and depth conversions for more accurate structure maps of all surfaces.

This study was the first to compare interpreted seismic discontinuities to horizontal well gas production. More comparisons of discontinuity frequency and production should be completed on other seismic surveys in the Marcellus shale. Another study may be completed comparing the orientation of interpreted seismic discontinuities with the orientation of lateral wells in context of gas production and maximum stress orientation. This would be especially interesting if completed over multiple seismic surveys in the Appalachian basin.

Further analyses on production may be completed for this study area if more information about the wells is obtained. Useful information for production analyses includes perforation locations and pumping parameters. 


\section{REFERENCES CITED}

Altamar R. P., and Marfurt K., 2014, Mineralogy-based brittleness prediction from surface seismic data: Application to the Barnett Shale, Interpretation Vol. 2, No. 4, p. T255-T271

Alzate Buitrago J. H., 2012, Integration of Surface Seismic, Microseismic, and Production Logs for Shale Gas Characterization: Methodology and Field Application, M.S. Thesis, University of Oklahoma Graduate College, Norman, Oklahoma

Alzate J. H., Perez R., Devegowda D., and Marfurt K. J., 2012, The value of production logging combined with 3D surface seismic in unconventional plays characterization, SEG Las Vegas 2012 Annual Meeting, doi:10.1190/segam2012-1592.1

Alzate J. H., and Devegowda D., 2013, Integration of surface seismic, microseismic, and production logs for shale gas characterization: Methodology and field application American Petroleum Institute, 2010, “Freeing Up Energy- Hydraulic Fracturing: Unlocking America's Natural Gas”, July 19, 2010, page 4.

Babarsky, A., 2012, 3D Seismic Attribute-Assisted Fracture Detection in the Middle Devonian Marcellus Shale, Greene and Washington Counties, PA, Central Appalachian Basin, M.S. Thesis, West Virginia University, Morgantown West Virginia

Beard, T., 2011, Fracture Design in Horizontal Shale Wells-Data Gathering to Implementation, EPA Hydraulic Fracture Workshop, March $10^{\text {th }}-11^{\text {th }}, 2011$, Web. http://water.epa.gov/type/groundwater/uic/class2/hydraulicfracturing/upload/fracturedesi gninhorizontalshalewells.pdf

Blakey, R.C., 2008, Gondwana paleogeography from assembly to breakup-A 500 m. y. odyssey, in Field-ing, C.R., Frank, T.D., and Isbell, J.L., eds., Resolving the Late Paleozoic Ice Age in Time and Space: Geological Society of America Special Paper 441, p. 1-28, doi: 10.1130/2008.2441(01).

Boyce, M. L., 2010, Sub-Surface Stratigraphy and Petrophysical Analysis of the Middle Devonian Interval of the Central Appalachian Basin; West Virginia and Southwest Pennsylvania, PhD. Dissertation, West Virginia University, Morgantown West Virginia

Brown, D., 2013, Zagorski Made His Mark With The Marcellus, AAPG Explorer, May 2013, p.32-34 
Caplinger, M.W., 1997. "Allegheny National Forest Oil Heritage". Historic American Engineering Record. National Park Service. July 8, 2011.

Castle, J.W., 2001, Appalachian basin stratigraphic response to convergent-margin structural evolution: Basin Research, v. 13, p. 397-418.

Cox T., 2007, Ant Tracking Seismic Volumes for Automated Fault Interpretation, AAPG Search and Discovery Article \#90168, Geoconvention, Alberta Canada May 14-17, 2007

Donahoe, T. B., 2011, 3D Seismic , Attribute-Assisted , Structural Interpretation for Hydrocarbon Exploration and Production : Southwest Pennsylvania, Central Appalachian Basin. Print.

Doveton, J. H., 1994, Geological Log Interpretation: Reading the Rocks from Wireline Logs. SEPM Short Course Notes No. 29. 91-116 pp.

Engelder T., Lash G. G., Uzcategui R.S., 2009, Joint sets that enhance production from Middle and Upper Devonian gas shales of the Appalachian Basin, AAPG Bulletin, V. 93, No. 7, July 2009, p.857-889

Ettenshon, F. R., 2004, Modeling the nature and development of major Paleozoic clastic wedges in the Appalachian Basin, USA, Journal of Geodynamics, Vol. 37, p. 657-681

Faill, R.T., 1997, A Geologic history of the North-Central Appalachians, Part 2: The Appalachian basin from Silurian through the Carboniferous, American Journal of Science, Vol. 297, p. 729-760.

Fitcher, L. S., 1993, The Geological Evolution of Virginia, Divided into Fourteen Stages A-M. http://csmres.jmu.edu/geollab/vageol/vahist/13xsect.PDF.

Gadallah M. R., and Fisher R., 2009, Exploration Geophysics: A comprehensive introduction to Exploration Geophysics, Chapter 6: Seismic Interpretation, Subsurface Maps, DOI: 10.1007/978-3-540-85160-8, p. 213

Gao, D., Shumaker, R. C., and Wilson, T. H., 2000, Along-Axis Segmentation and Growth History of the Rome Trough in the Central Appalachian Basin, AAPG Bulletin, V. 84, No. 1 January 2000, p. 75-99

Gao, D., 2002, Seismic textures aid exploration: Offshore, 62 (9), 65.

Gao, D., 2004, Texture model regression for effective feature discrimination: Application to seismic facies visualization and interpretation. Geophysics, 69. 958-967. 
Grieser, B., and J. Bray, 2007, Identification of production in unconventional reservoirs: SPE 106623 (SPE Production and Operations Symposium), Oklahoma City, OK, March 31April 3, 2007.

Gwinn, V. E., 1964, Thin-Skinned Tectonics in the Plateau and Northwestern Valley and Ridge Provinces of the Central Appalachians, Geological Society of America Bulletin 75, December 1963, DOI: 1130/0016-7606

Hart A., 2014, 3D Seismic Attribute-Assisted Analysis of Microseismic Events in the Marcellus Shale, M.S. Thesis, West Virginia University, Morgantown West Virginia, p. 115

Heidbach, O., Tingay, M., Barth, A., Reinecker, J., Kurfeß, D. and Müller, B., 2008, The World Stress Map database release 2008 doi:10.1594/GFZ.WSM.Rel2008.

Hilliard, V., 2015, Sequence Stratigraphy and Reservoir Characterization of the Middle Devonian Marcellus Formation for a Cored Well in Harrison County, West Virginia, M.S. Thesis, West Virginia University, Morgantown West Virginia

Horton, A.I., 1982, 95 simulations in 63 wells - DOE reports on comparative analysis of stimulation strategy in eastern gas shales: Columbus, $\mathrm{OH}$, Northeast Oil Reporter, p.6373, February 1982

Indiana Geological Survey, 2015, Petroleum Database Management System, Definitions: Type Log Well, Web Access: 11-15-2015, https://igs.indiana.edu/PDMS/Help/Type_Log_Well.htm

Jarvie, D. M., R. J. Hill, T. E. Ruble, and R. M. Pollastro, 2007, Unconventional shale-gas systems: The Mississippian Barnett Shale of North-Central Texas as one model for thermogenic shale-gas assessment: AAPG Bulletin, 91, 475-499, doi: $10.1306 / 12190606068$.

Kent, D.V., 1985, Paleocontinental setting for the Catskill Delta, in Woodrow, D.L., and Sevon, W.D., (Eds.): The Catskill Delta: Geological Society of America Special Paper 201, p. 9-14.

Kulander, C.S., and Ryder, R.T., 2005, Regional seismic lines across the Rome trough and Allegheny Plateau of northern West Virginia, western Maryland, and southwestern West Virginia: U.S. Geological Survey Geologic Investigations Series Map I-2791, 2 sheets, 9-p. pamphlet. (Also available at http://pubs.usgs.gov/imap/i2791/.) 
Marcellus Center for Outreach and Research, 2008, The Pennsylvania State University, University Park, PA http://www.marcellus.psu.edu/resources/maps.php

Mavko G., Mukerji T., and Dvorkin J., 2003, The Rock Physics Handbook, Cambridge University Press.

Milici R. C. and Swezey C. S., 2006, Assessment of Appalachian Basin Oil and Gas Resources: Devonian Shale-Middle and Upper Paleozoic Total Petroleum System: U.S. Geological Survey Open-File Report 2006-1237

Najmuddin I. J., 2001, Frequency Attenuation: A Fracture Indicator, Houston Geological Society Bulletin Feature Article, March 2001

Naylor, R.S., 1971. Acadian Orogeny: An Abrupt and Brief Event, Science, Vol. 172, p. 558560

PacWest Publishes Updated Shale/Unconventional Play Maps, 2014, Web. 10 Dec. 2014. http://pacwestcp.com/2012/07/pacwest-publishes-updated-shaleunconventional-playmaps/.

Parsons, R.C., Dahl, H.D., 1972. A study of the causes of roof instability in the Pittsburg coal seam, 7th Canadian Rock Mechanics Symposium. Mines Branch, Department of Energy, Mines and Resources, Ottawa, Edmonton.

Pederson S. I., Randan T., Sonnelans L., Steen O., 2002, Automatic Fault Extraction using Artificial Ants, SEG International Exposition and $72^{\text {nd }}$ Annual Meeting, Salt Lake City, Utah, October 6-11, 2002

Pederson S. I., Skov T., Hetlelid A., Fayemendy P., Randen T., Sonneland L, 2003, New Paradigm of Fault Interpretation, SEG Technical Program Expanded Abstracts 2003: pp. 350-353.doi: 10.1190/1.1817918

Perez R., and Marfurt K., 2013, Calibration of Brittleness to Elastic Rock Properties via Mineralogy Logs in Unconventional Reservoirs, Search and Discovery Article \#41237

Plumb, R.A., Cox, J.W., 1987. Stress directions in eastern North America determined to $4.5 \mathrm{~km}$ from borehole elongation measurements. Journal of Geophysical Research, 92: 48054816.

Range Resources, 2015, Company Presentations, October $28^{\text {th }}, 2015$; http://ir.rangeresources.com/phoenix.zhtml?c=101196\&p=irol-presentations 
Repetski, J. E., Ryder, R. T., Avary, K. L., and Trippi, M.H., 2005, Thermal maturity patterns (CAI and \%Ro) in the Ordovician and Devonian rocks of the Appalachian basin in West Virginia: U.S. Geological Survey Open-File Report 2005-1087, p. 69

Rickman, R., M. Mullen, E. Petre, B. Grieser, and D. Kundert, 2008, A practical use of shale petrophysics for stimulation design optimization: all shale plays are not clones of the Barnett Shale: Presented at the 2008 Annual Technical Conference and Exhibition, SPE, SPE 115258

Roberts, E. D., 2013, Structure Segmentation and Transfer Faults in the Marcellus Shale, Clearfield County, PA: Implications for Gas Recovery Efficiency and Risk Assessment in Central Appalachian Basin Using 3D Seismic Attribute Analysis, M.S. Thesis, West Virginia University, Morgantown West Virginia, p. 79-81

Ross J., 2015, EQT ready to drill Utica in West Virginia, The State Journal: West Virginia's Business, July $31^{\text {st }}, 2015$, http://www.statejournal.com/story/29681418/eqt-ready-to-drillutica-in-west-virginia

Ryder, R.T., Crangle, R.D., Jr., Trippi, M.H., Swezey, C.S., Lentz, E.E., Rowan, E.L., and Hope, R.S., 2009, Geologic cross section D-D' through the Appalachian basin from the Findlay arch, Sandusky County, Ohio, to the Valley and Ridge province, Hardy County, West Virginia: U.S. Geological Survey Scientific Investigations Map 3067, 2 sheets, 52-p. pamphlet.

Shelor J., 2015, Antero to drill first Utica well in West Virginia in 2015, The Exponet Telegram July $17^{\text {th }} 2015$, http://www.theet.com/news/local/antero-to-drill-first-utica-well-in-westvirginia-in/article_4eb1947e-c38c-5d98-9442-e5642a635270.html

Schlumberger, 2016, Case Study: Marcellus Shale Operator Receives At-Surface Formation Evaluation in Near Real Time, http://www.slb.com/resources/case_studies/geoservices/geoflex_marcellus_cs.aspx

Schrinder, L.A., and Wise, R.L., 1980, Potential new sources of natural gas: Journal of Petroleum Technology, v.32, no. 4, p. 703-716, DOI 10.2118/7628-PA

Shumaker, R.C., and T.H. Wilson, 1996, Basement structure of the Appalachian foreland in West Virginia: its style and effect on sedimentation, in B.A. van der Pluijm and P.A. Catacosinos, eds., Basement and basins of eastern North America: Geological Society of America Special Paper 308, p. 141-155. 
Sheriff R. E., 1997, Encyclopedia Dictionary of Exploration Geophysics, Third Edition, p. 99100

Soeder, D.J., and Kappel, W.M., 2009, Water Resources and Natural Gas Production from the Marcellus Shale, U.S. Geological Survey Fact Sheet

Unconventional Energy Resources, 2014, Web. 11 Dec. 2014. http://unconventionalenergyresources.com/.

U.S. Energy Information Administration, Independent Statistics and Analysis, 2014. Shale Gas Provides Largest Share of U.S. Natural Gas Production in 2013. Web. 12 Dec. 2014. http://www.eia.gov/todayinenergy/detail.cfm?id=18951.

U.S. Energy Information Administration, Independent Statistics and Analysis, 2015. U.S. Crude Oil and Natural Gas Proved Reserves. Web. 23 Nov. 2015. https://www.eia.gov/naturalgas/crudeoilreserves/

Wang, F. P., and J. F. W. Gale, 2009, Screening criteria for shale-gas systems: Gulf Coast Association of Geological Societies Transactions, 59, 779-793.

Weicht D., 2015, 3D Seismic, Mechanical Stratigraphy, and Petrophysical Analysis of the Marcellus Shale in Taylor County, West Virginia, M.S. Thesis, West Virginia University, Morgantown West Virginia, p. 36-37

West Virginia Geological and Economic Survey, 2011, WVGES Publication Map 25A, Map Date: May 16, 2011 http://www.wvgs.wvnet.edu/.

Wilson T. H., 2000, Seismic Evaluation of Differential Tectonic Subsidence, Compaction, and

Loading in an Interior Basin, AAPG Bulletin, Vol. 84, No. 3, p. 376-398

Wilson, T., A. Wells, D. Peters, A. Mioduchowski, G. Martinez, G. Koperna, B. Akwari, and J. Heath, 2012, Fracture and 3D seismic interpretations of the Fruitland Formation and cover strata: Implications for CO2 retention and tracer movement, San Juan Basin pilot test: International Journal of Coal Geology, 99, 35-53, doi: 10.1016/j.coal.2012.02.007.

Wilson, T., V. Smith, and A. Brown, 2013, Developing a strategy for CO2 EOR in an unconventional reservoir using 3D seismic attribute workflows and fracture image logs: 83rd Annual International Meeting, SEG, Expanded Abstracts, 2563-2567.

Wilson T. H., 2015, Microseismic: Listening to the Rocks GEOL 693B, Graduate Student Lecture, West Virginia University, Morgantown West Virginia, October 2015 
Wilson T. H., Hart A. K., and Sullivan P., 2016, Interrelationships of Marcellus Shale gas production to frac-induced microseismicity, interpreted minor faults and fractures zones, and stimulated reservoir volume, Greene County, Pennsylvania, Interpretation, Vol. 4, No. 1, February 2016, p.1-16

Wrightstone, G., 2009, "Marcellus Shale - Geologic Controls on Production.” Search and Discovery September (2009): p. 1-10. Web. 27 January 2015.

Zagorski, W. A., Wrightstone, G. R., Bowman, D. C., 2012, The Appalachian Basin Marcellus Gas Play: Its History of Development, Geologic Controls on Production, and Future Potential as a World-class Reservoir, in J.A. Breyer ed., Sale Reservoirs- Giant Resources for the $21^{\text {st }}$ Century: AAPG Memoir 97, p. 172-200.

Zhu L., 2013, 3D Seismic Interpretation and Well Log Analysis of the Marcellus Shale of Appalachian Basin at Taylor County, West Virginia, M.S. Thesis, West Virginia University, Morgantown West Virginia, p. 63

Zoback M.D., and Zoback M. L., 1991, Tectonic stress field of North America and relative plate motions, in The Geology of North America, Decade Map vol. 1, Neotectonics of North America, edited by B. Slemmons et al., pp. 339-366, Boulder, Colo., 1991 